\author{
UNIVERSIDADE DE SÃO PAULO \\ Instituto de Física \\ Instituto de Química \\ Instituto de Biociências \\ Faculdade de Educação
}

\title{
Um olhar sobre a educação continuada de professores das Séries Iniciais em Ciências no Estado de São Paulo
}

MARI INEZ TAVARES

Orientador: Prof ${ }^{\mathrm{a}} \mathrm{Dr}^{\mathrm{a}}$ Daisy de Brito Rezende

Dissertação de Mestrado apresentada aos Institutos de Física, Química, Biociências e à

Faculdade de Educação da Universidade de São

Paulo, para a obtenção do título de Mestre em Ensino de Ciências.

Área de concentração: Ensino de Ciências Modalidade Química

Orientador: $\operatorname{Prof}^{\mathrm{a}} \mathrm{Dr}^{\mathrm{a}}$ Daisy de Brito Rezende 


\author{
UNIVERSIDADE DE SÃO PAULO \\ Instituto de Física \\ Instituto de Química \\ Instituto de Biociências \\ Faculdade de Educação
}

\title{
Um olhar sobre a educação continuada de professores das Séries Iniciais em Ciências no Estado de São Paulo
}

MARI INEZ TAVARES

Orientador: Prof ${ }^{\mathrm{a}} \mathrm{Dr}^{\mathrm{a}}$ Daisy de Brito Rezende

Dissertação de Mestrado apresentada aos Institutos de Física, Química, Biociências e à Faculdade de Educação da Universidade de São Paulo, para a obtenção do título de Mestre em Ensino de Ciências.

Área de concentração: Ensino de Ciências Modalidade Química

Orientador: $\operatorname{Prof}^{\mathrm{a}} \mathrm{Dr}^{\mathrm{a}}$ Daisy de Brito Rezende 


\title{
MARI INEZ TAVARES
}

\section{Um olhar sobre a educação continuada de professores das Séries Iniciais em Ciências no Estado de São Paulo}

\author{
Dissertação de Mestrado apresentada aos \\ Institutos de Física, Química, Biociências e à \\ Faculdade de Educação da Universidade de São \\ Paulo, para a obtenção do título de Mestre em \\ Ensino de Ciências.
}

Orientador: $\operatorname{Prof}^{\mathrm{a}} \mathrm{Dr}^{\mathrm{a}}$ Daisy de Brito Rezende

BANCA EXAMINADORA

Prof $^{\mathrm{a}} \mathrm{Dr}^{\mathrm{a}}$ Maria Eunice Ribeiro Marcondes (USP)

Prof $^{\mathrm{a}} \mathrm{Dr}^{\mathrm{a}}{ }^{\mathrm{a}}$ Roseli Pacheco Schnetzler (UNIMEP) 


\section{FICHA CATALOGRÁFICA}

Preparada pelo Serviço de Biblioteca e Informação do Instituto de Física da Universidade de São Paulo

Tavares, Mari Inez

Um olhar sobre a educação continuada em Ciências de professores das Séries iniciais no Estado de São Paulo - São Paulo, 2009.

Dissertação (Mestrado) - Universidade de São Paulo. Institutos de Química; Instituto de Física; Instituto de Biociências e Faculdade de Educação.

Orientador: Profa. Dra. Daisy de Brito Rezende Matemática

Área de Concentração: Ensino de Ciências e

Unitermos: 1. Química - Estudo e ensino; 2. Ensino (Experimentação); 3. Ensino fundamental; 4.Formação continuada do professor. 
Este exemplar corresponde à redação final da Dissertação defendida por Mari Inêz Tavares e aprovada pela Comissão Julgadora.

São Paulo, 25 de maio de 2009.

Daisy de Brito Rezende orientadora 
Dedico este trabalho:

aos meus pais, Sebastião e Mercedes que sempre estão presentes na minha vida e que muito lutaram para que as filhas tivessem acesso à escola, às minhas irmãs Marici e Marci, aos meus sobrinhos Cristiam e Simone que não me deixaram esmorecer nesta jornada. 


\section{AGRADECIMENTOS}

A todos os meus professores que contribuíram para a minha formação no Primeiro e no Segundo Grau. Resolvi trilhar o mesmo caminho, sabendo que em alguns momentos era árduo porque tive exemplos que me fizeram apaixonar tão cedo pela Educação.

Aos meus companheiros de trabalho que compartilham a arte e o saber do "ofício" de mestre.

Aos diretores de escola: Vladimir Teófilo Fragnan Filho e Maria de Lourdes Longo, gestores das escolas E.E. Profa Marina Cintra e E.E. Prof ${ }^{a}$ Irene Branco Silva que com muito entusiasmo aceitaram que fossem ministrados os cursos de formação continuada nessas escolas.

Aos professores e às crianças participantes da pesquisa. Sem eles não seria possível escrever esta Dissertação.

À Prof ${ }^{\mathrm{a}} \mathrm{Dr}^{\mathrm{a}}$ Daisy de Brito Rezende, mulher sábia, determinada e amiga que por inúmeras vezes me orientou em período "noturno e integral", ou seja das $18 \mathrm{~h} 00$ às $5 \mathrm{~h} 00$, quando não havia nenhuma possibilidade de fazê-lo em outro horário devido ao meu emprego. Pacientemente e com e com muita dedicação revisou, sugeriu e criticou os meus escritos. Graças a esse empenho, tornei-me autônoma no meu pensar sobre Educação em Ciências.

Às Prof ${ }^{\text {as }} \operatorname{Dr}^{\text {as }}$ Maria Eunice Ribeiro Marcondes e Roseli Pacheco Schnetzler que muito me auxiliaram ao fazerem parte da banca de qualificação.

À minha amiga e futura comadre Michele, companheira de discussões sobre a Educação em Química desde os tempos da Licenciatura no Mackenzie.

Ao mais novo amigo e futuro compadre Geraldo, pelas sugestões quanto à Análise do Discurso.

Aos amigos: Leonardo e Marcos pelas parcerias na elaboração de resumos e artigos de nosso grupo de pesquisa. 
O que ouço, eu esqueço. O que vejo, eu lembro. O que faço, eu entendo.

Confúcio 


\section{Resumo}

Tavares, M.I.Um olhar sobre a educação continuada de professores das Séries Iniciais em Ciências no Estado de São Paulo.2009. 200p. Dissertação (Mestrado) Universidade de São Paulo, 2009.

A presente dissertação insere-se na linha de pesquisa formação continuada de professores. Pretendeu-se analisar o percurso de dois cursos de formação continuada de professores das séries iniciais em ciências que tinham por finalidade construir e discutir o conceito de transformação de materiais, além de favorecer uma reflexão a respeito do ensino de ciências para crianças através da criação de atividades experimentais, além do fortalecimento da autonomia dos professores cursistas. O contexto escolhido foi a utilização de um material didático que possui as suas atividades orientadas pela metodologia construtivista (PROQUIM).

Esta investigação realizou-se com o corpo docente das séries iniciais de duas escolas: denominadas respectivamente de escolas "A" e "B". A primeira localizada na região central da cidade de São Paulo e a segunda localizada na Zona Leste do mesmo município. Ao todo participaram 37 professores.

Esta investigação foi dividida em duas partes intimamente ligadas: a primeira abrangendo o convite ao curso de formação continuada, o próprio curso em si e a criação de atividades experimentais para crianças das séries iniciais do Ensino Fundamental. A segunda envolveu entrevistas com os professores após um ano decorrido o curso de formação. Esta entrevista teve por finalidade verificar se houve influência ou não do curso de formação continuada nas concepções dos professores a respeito do ensino de ciências para crianças que freqüentam as séries iniciais.

A metodologia de análise consistiu na análise do conteúdo proposta por Laurence Bardin das respostas dadas às atividades desenvolvidas, à entrevista realizada com alguns professores envolvidos e do texto produzido pelos alunos dos professores entrevistados.

Pode-se concluir da investigação que os professores que foram influenciados pelo curso desenvolveram aulas experimentais que envolvia diálogos em pequeno e grandes grupos que também influenciaram as crianças, pois estas não tiveram dificuldade em expressar-se por escrito causas e conseqüências. Já as crianças dos professores que não foram influenciados pelo curso que mantiveram a sua prática docente semelhante àquela de quando se formaram na Habilitação Específica para o Magistério, além da dificuldade de expressar-se por escrito sobre causas e conseqüências, elaboraram o texto como se fosse uma cópia de texto de livro didático. 
A nossa perspectiva é que no futuro este estudo de caso possa colaborar com ações de formação continuada em Ciências para professores das séries iniciais no que tange à metodologia de curso e na reorganização de livros didáticos de ciências destinados para crianças no que se refere à inclusão de atividades experimentais.

Palavras-chave: ensino de Ciências, formação de professores, construtivismo 


\begin{abstract}
Tavares, M.I. A wiew on the science formation of Elementary school teachers in na in service short course. 2009. 200p. Dissertação (Mestrado) Universidade de São Paulo, 2009.

The present study focuses on the in service formation in science of Elementary school teachers. The goal of this work was to unveil the influence of a short course on the teachers practice in classrooms in what regards science teaching to the children. To achieve this goal we employed a constructivist teaching strategy.

The public involved in the work was constituted of 27 teachers of two different schools settled in São Paulo city.

The investigation involved an in service course and interviews with some of the teachers besides some activities with their students.

The data were collected from the sources through content analysis employing the propositions from Laurence Bardin.

We conclude that part of the teachers were influenced by the activities developed in the course and a more intensive in service modality coud be more effective.

Key words: science teaching, teacher in service formation, elementary school.
\end{abstract}




\section{LISTA DE ILUSTRAÇÕES}

\section{CAPÍTULO 3}

Figura 3.1

CAPÍTULO4

Figura 4.1

Figura 4.2

Figura 4.3

Figura 4.4

Figura 4.5

CAPÍTULO 5

Figura 5.1

Figura 5.2

Figura 5.3

Figura 5.4

Figura 5.5

Figura 5.6

Figura 5.7

Figura 5.8

Figura 5.9

Figura 5.10

Figura 5.11

Figura 5.12

Figura 5.13

Figura 5.14

Figura 5.15

Figura 5.16

Figura 5.17

Figura 5.18

Figura 5.19

Figura 5.20
Dissertações e Teses sobre o tema formação de professores da séries iniciais em Ciências

Tabela I-1"

Item VII - Exercícios

Categorias e Sub-Categorias da Dimensão Curso de Formação 78 Continuada

Categorias e Sub-Categorias da Dimensão Formação Docente 80

Exemplo de atividade de aluno de "Não Houve Influência" 82

Mapa conceitual de "água" para E1 85

Mapa conceitual de "água" para E2 85

Mapa conceitual de "água" para E2 86

Mapa conceitual de "substância química água" para E1 86

Mapa conceitual de "substância química água" para E1 87

Mapa conceitual de "substância química água" para E2 87

Exemplo de tabela individual "Reconhecendo transformações" 91

Exemplo da Tabela de Dados 92

Exemplo da atividade VII e VIII -Exercícios 93

Atividade de aluno de E1A referentes à experimentação 105

Atividade de um aluno de E2A 106

Atividade de uma aluno de E2A 107

Atividade de um aluno de E1B 113

Atividade de um aluno de E1B $\quad 114$

Atividade de um aluno de E1C 115

Atividade de um aluno E1C 116

$\begin{array}{ll}\text { Atividade de um aluno de E1D } & 117\end{array}$

Atividade de um aluno de E1D 117

$\begin{array}{ll}\text { Atividade de um aluno de E2B } & 118\end{array}$

Atividade de um aluno de E2C 119 


\section{LISTA DE TABELAS}

\section{CAPITULO 3}

Tabela 3.1

CAPÍTULO 4

Tabela 4.1

Tabela 4.2

Tabela 4.3

Tabela 4.4

Tabela 4.5

Tabela 4.6

Tabela 4.7

CAPÍTULO 5

Tabela 5.1

Tabela 5.2

Tabela 5.3
Sistema de Ensino Brasileiro e Europeu

44

Técnicas/instrumentos para recolha e análise de dados 67

Professores participantes da pesquisa 68

Crianças participantes da pesquisa $\quad 69$

$\begin{array}{ll}\text { Planejamento } & 71\end{array}$

Exemplos de evocações de professores e alunos para categoria Houve 78 Influência

Exemplo de evocações de professores e alunos para sub-categoria da 79 categoria Houve Influência

Exemplo de evocações de professores e alunos para a categoria Não Houve Influência

Transformação e número de evocações

Evocações de alunos pertencentes à categoria houve influência 108

Evocações de alunos pertencentes à categoria Não Houve Influência.

\section{LISTA DE QUADROS}

\section{CAPÍTULO 4}

Quadro 4.1

Quadro 4.2

Quadro 4.3

Quadro 4.4

Quadro 4.5

CAPÍTULO 5

Quadro 5.1

Quadro 5.2

Quadro 5.3

Quadro 5.4

Quadro 5.5

Quadro 5.6

Quadro 5.7

Quadro 5.8

Quadro 5.9

Quadro 5.10

Quadro 5.11

Quadro 5.12

Quadro 5.13
Perguntas utilizadas na entrevista

Evocações do Capítulo I "Houve Ressignificação" e "Não Houve 77 Ressignificação"

Evocações da formação inicial docente 81

Evocações da formação continuada anteriores ao curso ministrado 81

Exemplo de como foram extraídos as categorias e subcategorias 82

Respostas às questões de análise e síntese do Capítulo I. 94

Respostas dos professores sobre a questão 3.

Respostas de análise e síntese do item densidade. 96

Propostas de aula da Professora E2A 96

$\begin{array}{ll}\text { Propostas de aula da Professora E2B } & 97\end{array}$

$\begin{array}{ll}\text { Propostas de aula da Professora E2C } & 97\end{array}$

$\begin{array}{ll}\text { Propostas de aula da Professora E2D } & 97\end{array}$

Exemplo de trecho referente à sub-categoria dialogia 100

Exemplo de trecho referente à sub-categoria dialogia, quanto à 100 receptividade dos alunos.

Exemplo de trecho referente à sub-categoria dialogia, quanto aos resultados observados

$\begin{array}{ll}\text { Exemplo de trecho referente à categoria livro didático } & 102\end{array}$

$\begin{array}{ll}\text { Trechos referentes à sub-categoria experimentação } & 103\end{array}$

Relatos dos professores quanto ao uso de mapa conceitual 104 
Quadro 5.14 Referente à sub-categoria expressões tecnicistas.

$\begin{array}{lll}\text { Quadro 5.15 } & \text { Referente à monologia } & 110\end{array}$

$\begin{array}{lll}\text { Quadro 5.16 } & \text { Referente à demonstração }\end{array}$

Quadro 5.17 Referente à sub-categoria livro didático de Não Houve Ref. 112

$\begin{array}{lll}\text { Quadro 5.18 } & \text { Referente à sub-categoria de formação docente } & 120\end{array}$

Quadro 5.19 Referente à sub-categoria de formação docente $\quad 121$

$\begin{array}{lll}\text { Quadro 5.20 } & \text { Referente à sub-categoria de formação docente } & 122\end{array}$

Quadro 5.21 Referente à sub-categoria de formação docente 122

Quadro 5.22 Referente à sub-categoria de formação docente 123

Quadro 5.23 Referente à sub-categoria de formação docente 123

Quadro 5.24 Referente à sub-categoria de formação docente 124

Quadro 5.25 Referente à sub-categoria de formação continuada 124

Quadro 5.26 Referente à sub-categoria de formação continuada 125

\section{ABREVIATURAS}

\begin{tabular}{|c|c|}
\hline ABC & Academia Brasileira de Ciências \\
\hline CEDOC & $\begin{array}{l}\text { Centro de Documentação em Ensino de Ciências Faculdade de Educação da } \\
\text { UNICAMP }\end{array}$ \\
\hline CEFAM & Centros Específicos de Formação e Aperfeiçoamento do Magistério \\
\hline CFE & Conselho Federal de Educação \\
\hline CNE/CP & Conselho Nacional de Educação/ Conselho \\
\hline DRECAP-3 & Divisão Regional do Ensino da Capital-3 \\
\hline E1 & Escola 1 \\
\hline E2 & Escola 2 \\
\hline EF-I & Ensino Fundamental I \\
\hline HEM & Habilitação Específica para o Magistério do 2Grau \\
\hline HTPC & Horário de Trabalho Pedagógico Coletivo \\
\hline IMESP & Imprensa Oficial do Estado de São Paulo \\
\hline PCN-Ciên & Parâmetros Curriculares Nacionais de Ciências \\
\hline PROQUIM & Projeto de Química para o $2^{\circ} \mathrm{Grau}$ \\
\hline SEE & Secretaria de Estado da Educação de São Paulo \\
\hline UFBA & Universidade Federal da Bahia \\
\hline UFF & Universidade Federal Fluminense \\
\hline UFRGS & Universidade Federal do Rio Grande do Sul \\
\hline UFSCAR & Universidade Federal de São Carlos \\
\hline UNICAMP & Universidade de Campinas \\
\hline USP & Universidade de São Paulo \\
\hline
\end{tabular}




\section{SUMÁRIO}

Tenho muitos nomes. Alguns são tão antigos que só o vento sabe pronunciá-los 16

Um pouco da história de Ofélia 18

Estrutura da Dissertação $\quad 20$

Capítulo1: Introdução - A chegada ao portal do labirinto da história da formação cde professores das sérieis iniciais de São Paulo

1.1 O portal do Labirinto: O ensino de Ciências para crianças e a formação de professores pra as séries iniciais no Brasil

1.2 A descida ao labirinto e o encontro com o Fauno

Capítulo 2: Objetivos - O encontro com Fauno e as Fadas

2.1 As fadas que estão na algibeira do Fauno: a pergunta de pesquisa 33

Capítulo 3: Revisão da Literatura - A leitura do Livro das Encruzilhadas 35

3.1 Um dos corredores do labirinto: o Ensino de Ciências das Séries Iniciais $\quad 36$

$3.2 \mathrm{O}$ ensino de Ciências para crianças no contexto europeu 43

3.3 A pesquisa de formação de professores nos países de língua inglesa 48

3.4 A primeira Escola Normal Paulista (Brasil Monárquico $-2^{2}$ metade do Século XIX.

3.5 As Escolas Normais Paulistas da República Velha (1889 a 1930) 53

3.6 A Escola Normal Paulista da República Populista (1930-1964) 56

3.7 O fim da Escola Normal e o surgimento da Habilitação Específica para o Magistério em São Paulo durante a Ditadura Militar (1964-1965)

3.8 A Habilitação Específica para o Magistério Paulista da Nova República (de 1985 até dias atuais)

Capítulo 4: Metodologia - As provas de Ofélia 62

4.1 Pressupostos 63

4.2 Caracterização do estudo 66

4.3 O giz mágico: O curso de Formação Continuada 68

$\begin{array}{ll}\text { 4.4 Materiais Coletados } & 71\end{array}$

4.5 O punhal obtido do Palácio de Pale Man: recortando os discursos sob a óptica de Bakthin e Vygotsky

Capítulo 5: Resultados e Discussão - A última prova de Ofélia 83

5.1 Análise das atividades iniciais do curso: caracterização dos professores $\quad 84$

5.2 Quando Ofélia vive e se torna a princesa Moana: os professores e alunos que fizeram referências ao curso.

5.3 Quando Ofélia morre nas mãos do general : os professores e alunos que não fizeram referências ao curso. 
5.4 A formação docente dos professores participantes: um passeio com Fauno nos jardins concêntricos do Reino Subterrâneo

Capiítulo 6: Conclusões

6.1 Comentários

6.2 Perspectivas

7 Bibliografia

8. Anexos 


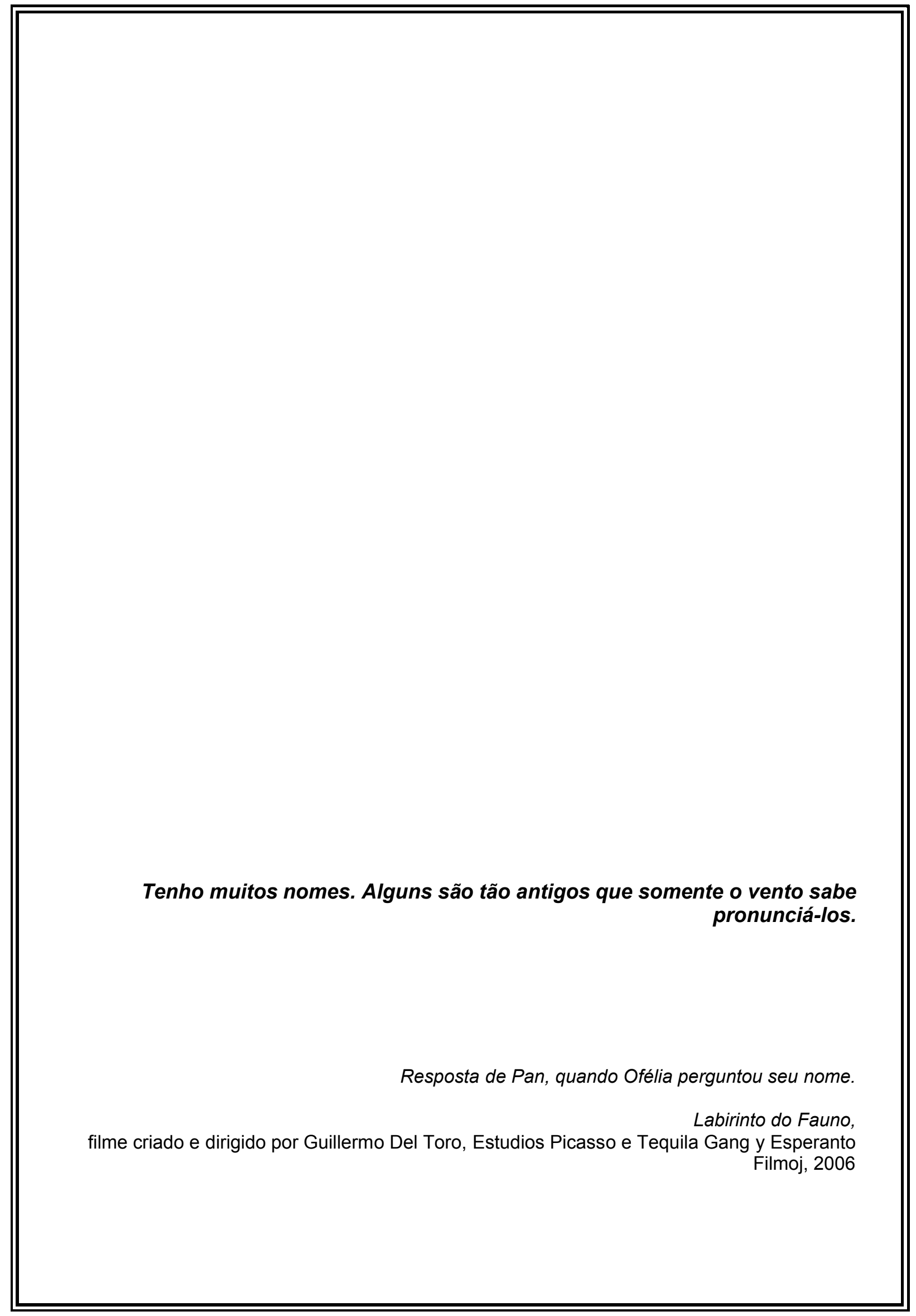




\section{㸷or certo o leitor desta Dissertação deve estar se perguntando:}

Afinal, a resposta do Fauno a Ofélia se relaciona à questão da formação continuada dos professores das séries iniciais?

Pan, ser mitológico na Grécia Antiga, símbolo do Universo e personificação da Natureza nada tem a ver com o quê será relatado aqui, mas a resposta dada pelo Fauno à menina Ofélia é igual àquela dada por um outro ser, tão fantástico quanto Pan, mas que se assemelha muito mais a outro personagem do filme de Del Toro: o Pale Man, um monstro horrendo, devorador de criancinhas e que possui olhos nas mãos. $O$ ser polimorfo chama-se Problema da Formação dos Professores das Séries Iniciais em São Paulo que, como Fauno, possui muitos nomes, sendo alguns deles pronunciáveis apenas pelo vento. Para conhecer melhor o "monstro", ou melhor, saber quando ele surgiu, a investigadora, assim como Ofélia, adentrou pelo labirinto da História da Formação dos Professores em São Paulo com a finalidade de compreender os motivos pelos quais os professores das séries iniciais não ensinam Ciências aos seus alunos.

O dito, atribuído a George Santayana: "Quem não conhece história está fadado a repetir os erros do passado", fez com que a investigadora voltasse o olhar para o passado, procurando traçar um breve panorama das políticas públicas a partir de 1846, data da fundação da primeira Escola Normal, na então Província de São Paulo. Nessa trajetória, podem-se identificar vários aspectos relacionados ao atraso do ensino e da formação inicial ou continuada a que é submetido o professorado paulista das séries iniciais: tentativas, descontinuidades, busca incessante de modelos e métodos vindos de fora (raramente bem assimilados ou compreendidos e implantados sem grandes estudos ou adaptação à nossa realidade), dentre os mais flagrantes. Essa problemática complexa é sempre ressaltado para o público cada vez que um novo governante apresenta seu novo projeto educacional e quer implantá-lo, às vezes desestruturando o quê foi construído antes de seu mandato sem que tenha havido tempo do projeto anterior mostrar eficiência. Neste caso falta, por parte de quem assume o governo, a ética de terminar o que foi iniciado não levando em conta a filiação partidária de seu antecessor. Tais mudanças quando não fundamentadas, resultam em prejuízo às crianças e adolescentes que carregarão para o resto da vida a deficiência de sua formação. Quem não conhece História, a repete como farsa. 


\section{Um pouco da história de "Ofélia"}

A chave de todas as ciências é inegavelmente o ponto de interrogação.

Honoré Balzac

Zno: 1976. Ofélia, menina levada, adorava andar pelo imenso quintal de sua casa

atrás de.formigas! Essa garotinha de seis anos passava horas e horas observando o vai e vêm das saúvas pelo quintal e não resistia a capturá-las habilidosamente com a pinça de sobrancelhas de suas irmãs mais velhas, na intenção de construir seu formigueiro particular. Quando a pinça lhe escapava das mãos, levava algumas ferroadas, mas não se emendava. Colocava terra no vidro de maionese vazio e o forrava com folhas e pitadas de açúcar. Fazia furos bem pequenos na tampa, vedava o vidro e ficava dias e dias observando se as formigas fariam o formigueiro. A menina vivia perguntando de si para si: "de onde vêm e para onde vão essas formigas?" "Como conseguem ter tanta força para carregar pedaços de insetos e folhas tão grandes?" "Por que não fazem formigueiro no vidro de maionese se eu coloquei terra e alimentos?" Quando se cansava desse folguedo, ia para o galinheiro que ficava no fundo do quintal e ficava esperando que as galinhas botassem os ovos. Quando uma das galináceas "ia para a panela", adorava ficar ao lado da mãe, sobre uma cadeira, observando a depenação e a abertura daquela que seria a mistura. Surgia na cabeça de Ofélia outra pergunta: "por que os ovos não possuem clara e casca quando estão dentro da galinha?" Quando a noite chegava, a garota ficava deitada sobre a laje contando as estrelas e ... mais interrogações surgiam: "será que algum dia chegarei até lá e pegarei alguma dessas estrelas com a mão?" Gostava também de ver as irmãs adolescentes fazendo tie-die nas camisetas de algodão, o pai misturando tintas de várias tonalidades para pintar as paredes das casas do bairro ...

Como todos já sabem, a cada observação do mundo à sua volta, surgiam mais perguntas na cabeça da menina. Muitas vezes ela procurou os adultos com os quais convivia para ajudá-la a encontrar as respostas. A mãe, na sua simplicidade, respondiaIhe: porque é assim. O pai e as irmãs também lhe respondiam da mesma forma e a menina retrucava: mas, por que é assim? Não obtinha a resposta desejada.

$\mathrm{Na}$ casa da menina todos gostavam de ler: a mãe, os livros de receitas e revistas de bordados, o pai lia jornais e livros de todo tipo, a irmã do meio estudava no colegial e 
passava horas e horas trancada em seu quarto estudando e lendo livros e fotonovelas, de modo que a menina começou a querer ler e escrever. Se naquela casa os adultos não tinham muito sossego por causa da menina perguntadora, agora, com o desejo de ler e escrever, a paz havia se encerrado de vez.

O pai era servente de uma escola pública do bairro. De vez em quando, Ofélia ia ao trabalho do pai. Assim, a mãe poderia trabalhar nas costuras e em outros afazeres domésticos. A escola imensa e cheia de árvores tornou-se uma extensão do quintal. Xereta por natureza, logo descobriu na biblioteca da escola, uma infinidade de livros. A vontade de ler era tanta que quase aprendeu a ler sozinha. Nas horas vagas, uma professora a ajudava a aprender a ler e escrever, uma vez que na pré- escola ainda não se ensinava a leitura e a escrita.

Ofélia começou, então, a fazer perguntas para as professoras. Algumas perguntas eram respondidas assim: quando você crescer vai entender. Às vezes as professoras faziam de conta que não escutavam.

Quando aprendeu a ler com mais fluência a menina começou a freqüentar assiduamente a biblioteca da escola (antes entrava escondido para folhear os livros). Lia muitos livros como: a Enciclopédia Curiosa, O mundo da Estelândia e outros. Mas o que fascinava mesmo Ofélia eram os livros de Ciências. Passava horas e horas lendo livros sobre o corpo humano, animais, planetas e etc...Parte das perguntas da menina foram resolvidas com os livros, outras ficaram sem resposta.

Ofélia era muito inquieta na sala de aula pois terminava a lição primeiro que os outros e ficava andando de um lado para o outro. A professora não viu outro jeito e começou fazer com que colaborasse na arrumação do armário e ajudasse os colegas a ler. Ela gostava de ajudar os coleguinhas e com o tempo alguns deles passaram a freqüentar sua casa para brincar de escolinha. A mãe da menina fazia pão torrado e café com leite para oferecer às crianças. A menina decidiu que, quando crescesse, seria professora. Até ganhou no Natal uma lousa de brinquedo de sua irmã mais velha para brincar de escolinha.

O tempo passou e Ofélia cresceu...

Entrou em conflito quando foi decidir a sua carreira profissional, pois gostava tanto de Ciências como das Artes Plásticas. Queria optar por alguma escola técnica que abrangesse alguma dessas áreas. Depois de muitos conselhos da madrinha e da irmã do meio, ambas professoras, acabou formando-se no Magistério. Prestou concurso público na Rede Estadual de Ensino e, finalmente, chegou às salas de aula. Logo 
percebeu que essas salas estavam repletas de crianças com as cabeças cheias de perguntas como a sua e que também estavam sem uma resposta satisfatória. Foi a partir deste momento que a professora começou a ter uma compreensão do que se passara na sua infância e percebeu porque nem seus familiares nem suas professoras das séries iniciais respondiam suas perguntas de maneira satisfatória: as crianças fazem perguntas difíceis de serem respondidas por um adulto. Ofélia entrou em conflito porque não queria deixar seus alunos com as cabeças cheias de perguntas e começou a pensar em uma solução. Optou por fazer uma licenciatura em Química porque aliava o desejo anterior à profissão docente.

Os anos se passaram e Ofélia, percebendo que o problema não era as perguntas difíceis das crianças, mas sim como os professores eram formados, começou a pensar numa maneira de mudar sua prática docente. Refletiu sobre sua própria formação e lembrou-se que em nenhum momento teve alguma disciplina relacionada à Didática ou Metodologia das Ciências Naturais enquanto se preparava para ser professora das séries iniciais. Logo percebeu que não estava sozinha neste caminhar: outros colegas sentiam a mesma dificuldade e viu que somente a Licenciatura em Química não lhe seria suficiente. Começou, então, a procurar caminhos para resolver a questão. Enquanto refletia começou a fazer um curso de pós-graduação Lato Sensu em Química, que não Ihe foi suficiente. Ao mesmo tempo procurava junto às universidades, nos seus laboratórios, contatos para possíveis orientadores. Pensou em fazer mestrado em físico-química ou em bioquímica, mas essa formação não lhe daria a resposta desejada aos seus porquês. Foi quando uma professora the sugeriu que entrasse em contato com uma professora da Pós-Graduação Interunidades em Ensino de Ciências. A sábia mestra, Doutora em Fotoquímica Orgânica, com muita paciência ouviu todas as queixas e inquietações da colega que lecionava nas séries iniciais e aceitou o desafio de orientá-la numa Dissertação de Mestrado. O fruto deste trabalho é o que se segue...

\section{Estrutura da Dissertação}

A presente Dissertação de Mestrado está organizada em 06 Capítulos.

No primeiro Capítulo são relatados os motivos da pesquisadora para a realização da Dissertação e faz-se uma breve introdução sobre o ensino de Ciências para crianças no Brasil e sobre a formação de professores do período de 1970 até os dias atuais.

No segundo Capítulo, é delimitado o objetivo da presente Dissertação. 
O terceiro Capítulo é dedicado à história da formação inicial dos professores do $1^{0}$ Ciclo do Ensino Fundamental (EF-I), no qual se explicita o problema da formação continuada desses profissionais em Ciências e a revisão da literatura de artigos relacionados à temática em questão, explicitando quais os objetivos, a importância e as limitações encontradas em outras investigações sobre o tema estudado. Nesta revisão da literatura, estudou-se a formação continuada de professores do EFI em Ciências e o ensino de Ciências para crianças no Brasil, em Portugal, na Espanha e em alguns países de língua inglesa. Este terceiro capítulo apresenta, em seu corpo, uma série de aspectos que consideramos importantes e convergentes com o presente.

No quarto Capítulo, referem-se à metodologia e aos referenciais teóricos que nortearam o nosso trabalho, a caracterização do estudo, com descrição do trabalho, do público alvo, das técnicas e dos instrumentos de investigação, a sua elaboração, o recolhimento e tratamento de dados e a justificativa dos procedimentos de análise dos dados recolhidos.

O quinto Capítulo refere-se à discussão dos resultados encontrados no material produzido durante os cursos de formação continuada, na entrevista dos professores do EF-I e daqueles obtidos dos desenhos e escritas dos alunos, bem como sua triangulação desses dados e seus respectivos professores.

No sexto Capítulo, apresentam-se as conclusões, suas implicações e algumas sugestões para futuras investigações.

No segundo volume denominado Anexos, encontram-se relacionados atividades e entrevistas realizadas durante a coleta de dados. 
Capítulo 1: Introdução

A chegada ao portal do labirinto da história da formação de professores das séries iniciais de São Paulo 


\subsection{O Portal do Labirinto: $O$ Ensino de Ciências para crianças e a formação de professores para as séries iniciais no Brasil}

D carro pára em meio a uma estrada que corta uma grande floresta. Enquanto sua mãe gestante se recupera de um enjôo repentino durante a viagem, Ofélia desce do carro, e, curiosa, entra nesta mata para observar as plantas e os insetos. Encontra uma pedra de forma estranha e percebe que esta pedra é parte de um totem. Da boca do totem, sai então um fasmídeo. Curiosa, Ofélia tenta capturá-lo em vão. Chamada pela mãe para seguir viagem, Ofélia deixa o bosque a contragosto. O inseto passa então a seguir o carro até o seu destino. Ofélia reencontra o inseto ao redor do carro e este a conduz até o portal do labirinto...

Nesta Dissertação, a pedra que compõe o totem é representada pela pergunta:

Por que os professores do Ensino Fundamental I (EF-I) não ensinam Ciências aos seus alunos?

Esta pergunta possui muitas respostas que formam o corpo do totem que é a formação inicial dos professores que atuam no EF-I. A formação deficiente, devida aos problemas já mencionados, talvez seja um dos grandes motivos para o impedimento da transformação do ensino de Ciências nas séries iniciais pois, somente nos últimos doze anos dessa longa história, como veremos adiante, é que se iniciaram as reformas educacionais que incluíram Didática e Metodologia do Ensino de Ciências nos cursos de Pedagogia e Normal Superior (de existência efêmera, pois já foi extinto).

O fasmídeo, na verdade uma fada, representa a necessidade de pesquisa por parte da investigadora, que deseja encontrar uma resposta coerente para sua pergunta e, assim compreender o significado daquele totem. A fada guia Ofélia até o portal e a convida a adentrar e conhecer os recônditos mais profundos do labirinto. Nesta Dissertação, o conhecimento dos fatos precursores e a questão da formação continuada dos professores das séries iniciais é que formam o portal do labirinto e a história da formação dos professores, como dito anteriormente nos conduzirá a neste trabalho.

No Brasil, o ensino de Ciências para as séries iniciais é muito recente e nasceu da promulgação da Lei de Diretrizes e Bases no 5.692/71 (IMESP, 1979), segundo concepções expressas em uma série de documentos legais complementares. Por exemplo, os objetivos de ensino referentes às Ciências estão explicitados no item $\mathrm{c}$ do artigo $3^{\circ}$ da Resolução $\mathrm{n}^{\circ} 8$ (1/12/71) do Conselho Federal de Educação (CFE) e no Parecer no 853/71 do CFE (IMESP, 1979), que o acompanha, como visando "ao desenvolvimento do pensamento lógico e à vivência do método científico e de suas aplicações". Esse mesmo parecer, no que se refere 
à fixação do núcleo comum para os currículos do ensino de $1^{\circ}$ e $2^{\circ}$ graus, estabelece quanto às Atividades, Áreas de Estudo e Disciplinas que:

No início da escolarização, as Ciências só podem ser tratadas em termos de atividades, isto é, como vivência de situações e exercícios de manipulação para explorar a curiosidade, que é a pedra de toque do método científico. Sempre que oportuno essas experiências já podem ser objeto de uma incipiente sistematização partida mais do aluno do que do professor, embora sob a direção estimulante deste último. À medida que se esboçam certos setores ainda não claramente individualizados e tais sistematizações se tornam mais freqüentes pelo amadurecimento natural do educando, já temos a área de estudo (Ciências Exatas e Biológicas, p. ex.);... (IMESP, 1979, p.40).

E, com relação ao dimensionamento da amplitude do núcleo-comum, o caput e o $1^{\text {o }}$ parágrafo do artigo $4^{\circ}$ da Resolução $\mathrm{n}^{\circ} 8$ esclarecem que os conteúdos (matérias)

serão escalonados... da maior para a menor amplitude do campo abrangido, constituindo atividades, áreas de estudo e disciplinas", sendo que "nas atividades, a aprendizagem far-se-á principalmente mediante experiências vividas pelo próprio educando no sentido de que atinja, gradativamente, a sistematização de conhecimentos". Ainda, quanto ao ensino de ciências, o Parecer $n^{\circ}$ 853/71 (CFE; IMESP, 1979) afirma que esse deve ser tratado, até a quarta série do $1^{\circ}$ grau (1ํำ Ciclo do Ensino Fundamental), como..."Iniciação às Ciências (incluindo Matemática), tratadas predominantemente como atividades... (IMESP, 1979, p.52).

Em nível Estadual (São Paulo), a Indicação do Conselho Estadual de Educação no 1/72 (IMESP, 1979, p.159), organizou os objetivos educacionais de acordo com a taxonomia de BENJAMIN BLOOM (1973), sendo que a organização do ensino de Ciências foi sumariada no sub-item 3.2.3 desse documento, com a seguinte redação:

\section{"3.2.3 - Ciências}

3.2.3.1 - Objetivos: - O ensino visará ao desenvolvimento lógico e à vivência do método científico e de suas aplicações (Artigo $3^{\circ}$ item c da Resolução 8/71 do CFE ).

\section{Físicas e Biológicas.}

3.2.3.2 - Conteúdo específico: - A Matemática e as Ciências

3.2.3.3 - Amplitude e extensão: - Nas duas $1^{\text {as }}$ séries tratadas predominantemente na forma de atividades. As percentagens abrangidas especificamente pela Matemática deveriam ser mais altas na $3^{a}$ e $4^{a}$ séries quando a sistematização do conhecimento começa a apresentar maiores dificuldades, para em seguida, equilibrar-se em relação às outras áreas que envolvem o estudo das Ciências Físicas e Biológicas e Ciências Sociais. A título de exemplificação, sem prejuízo de outras soluções adotadas pelo estabelecimento, reservar-se-iam os seguintes percentuais: $35 \%$ para a $1^{\underline{a}} \mathrm{e}$ $2^{a}$ séries, incluindo Matemática e Ciências, $15 \%$ para as $3^{\underline{a}}$ e $4^{\underline{a}}$ séries, para Ciências e 25\% para Matemática; $10 \%$ para as demais séries para Ciências, e em Matemática: $20 \%$ para a $5^{a}, 15 \%$ para as $6^{a}$ e $7^{a}$ e $10 \%$ para a $8^{a}$ série." (IMESP, 1979, p.169). 
Esse interesse inicial de se ensinar Ciências para as crianças originou-se do Movimento de Reforma Curricular que surgiu nos Estados Unidos e Inglaterra, nos anos 60, que não concordava com a metodologia empregada pelos cursos tradicionais de Química, Física e Biologia. Segundo KEMPA, (1976 apud, SCHNETZELER, 2002), esse Movimento estimulou a origem de questionamentos e investigações sobre os conteúdos de disciplinas científicas, as finalidades da educação em Ciências, as diferentes abordagens instrucionais e os efeitos dos novos currículos no que se refere aos alunos. Ainda hoje, os reflexos do Movimento de Reforma Curricular contribuem para a melhoria dos processos de ensino e aprendizagem em Ciências, tais como: (i) a idéia de currículo em espiral, que implica na seleção de conceitos fundamentais e sua organização através de grandes temas centrais, favorecendo um maior relacionamento conceitual; aulas experimentais para introduzir e explorar problemas; organização da sala de aula em grupos de alunos para realizar e discutir experimentos (SCHNETZELER, 2002)

Embora o ensino de Ciências para crianças fosse tratado nos documentos legais como Atividade nas séries iniciais, o que de fato predominava e ainda predomina na prática escolar atual era a cópia de textos e a elaboração de questionários utilizados como instrumentos de estudo e avaliação. Segundo o PCN-Ciên essa situação devia-se à ausência de espaços adequados para atividades experimentais na maior parte das escolas, pois somente em grandes centros de educação havia condições de se realizarem tais experimentos (BRASIL, 1997).

A partir da década de 70, foram feitos diversos estudos sobre o ensino de Ciências, cujo objetivo principal era o de contribuir para a construção de processos de ensino e aprendizagem de melhor qualidade e mais efetivos. Diversos desses trabalhos investigavam a compreensão de conceitos, enquanto outros se dirigiam à análise de currículos e de livros didáticos. O objetivo fundamental do ensino de Ciências passou a ser o de dar condições ao aluno para a "redescoberta" através do chamado "método" científico (BRASIL,1997). Já no fim da década, o volume de trabalhos em educação científica, tendo como linha de investigação as concepções espontâneas dos estudantes, cresceu acentuadamente. Muito desses trabalhos, tiveram como base teórica a concepção construtivista (LABURU E CARVALHO, 2005).

Embora pesquisas citadas anteriormente tenham contribuído para que houvesse uma melhor compreensão sobre o conteúdo das idéias dos estudantes e para o surgimento de novas metodologias de ensino, os professores generalistas acabaram ficando "perdidos" em meio a essa diversidade de metodologias (Bızzo, 1995). Professores com mais tempo de carreira ainda preferem seguir a proposta tradicional (isso quando há uma proposta) e relutam em adotar novas metodologias porque já têm um 'pré-conceito' de que ela não 
funcionará. Os professores novatos, por sua vez, acabam cedendo às pressões dos colegas mais antigos para não mudarem sua metodologia de ensino (Bızzo, 1995).

Não poderíamos abordar essa problemática sem antes conhecermos um pouco mais sobre como se deu essa formação de professores das séries iniciais. SELMA GARRIDO PIMENTA (1988), em seus escritos, relata que, da década de 70 até os anos finais da década de 80, a formação de professores para as séries iniciais (incorporada pela Lei $n^{\circ}$ 5.692/71) se caracterizou como uma habilitação que :

- apresentava-se esvaziada em conteúdo, pois não respondia nem a uma formação geral adequada nem a uma formação pedagógica consistente;

- era uma habilitação de "2a categoria", para onde se dirigiam os alunos com menos possibilidade de fazer cursos com mais "status";

- não havia qualquer articulação didática e de conteúdo entre as disciplinas do Núcleo Comum e as da parte profissionalizante nem entre estas e também entre a realidade do ensino de $1^{\circ}$ Grau e a formação profissional e entre o $3^{\circ}$ grau (Pedagogia) que formava os professores para a Habilitação ao Magistério;

- a Habilitação ao Magistério, conforme definida na lei, não permitia que se formasse o professor e menos ainda o especialista ( $4^{\circ}$ ano). A formação era fragmentada;

- os livros didáticos disponíveis, freqüentemente, transmitiam um conhecimento não-científico, dissociado da realidade sócio-cultural e política, bem como favorecem procedimentos de ensino mecanizados e desfocados das condições reais de aprendizagem dos alunos.

O cenário escolar predominante era o do tecnicismo que tinha tendência administrativa no taylorismo. Cada uma dessas habilitações (Formação Especial, isto é, Magistério na Pré-Escola; Ensino de $1^{\underline{a}}$ e $2^{\underline{a}}$ séries; Ensino de $3^{a}$ e $4^{a}$ séries) apresentava uma relação de disciplinas, cuja adoção pela escola seria obrigatória, de acordo com a área escolhida.

Assim, todos os professores formados entre 1977 a 1987, portanto, num período de 11 anos, foram influenciados pela tendência pedagógica do Tecnicismo, que sobreviveu, na legislação do ensino, por mais de uma década, graças ao seu criador, o Regime Militar.

Como a norma não proibia que os alunos formados para lecionar na pré-escola também o fizessem nas classes de primeira à quarta séries, essa super-especialização foi contornada pelas escolas. A imensa maioria dos cursos de formação de professores adotou a especialização dirigida ao ensino pré-escolar, o que habilitava seus alunos, após formados, a também atuarem nas quatro primeiras séries do ensino de $1^{\underline{0}}$ grau. Como nessa especialização não se incluía Conteúdo e Metodologia de Ensino das Ciências, conclui-se que a maioria dos professores das séries iniciais em exercício não tem qualquer preparo durante sua formação inicial para a abordagem de temas da área de Ciências.

Essa síntese das normas que regiam o curso do Magistério de Segundo Grau deixa claro que apenas os professores que se especializavam no ensino para terceiras e quartas séries 
tinham o curso de Metodologia do Ensino de Ciências na sua grade curricular. Nos planejamentos das escolas estaduais não constava ao menos uma disciplina que se relacionasse ao ensino de Ciências para as séries iniciais bem como para outras disciplinas como História e Geografia. Apenas Língua Portuguesa e Matemática eram priorizadas nesses cursos de formação. As demais disciplinas ficavam em segundo plano, fato que explica porque, ainda nos dias de hoje, professores das séries iniciais priorizam as disciplinas de Língua Portuguesa e Matemática, em detrimento das demais.

Em 1986, em uma parceria entre a Faculdade de Educação da Universidade de São Paulo (USP) e a antiga Divisão Regional de Ensino da Capital (DRECAP-3), realizou-se uma análise acompanhada de reflexão sobre os planos de Habilitação Específica para o Magistério (HEM) das escolas jurisdicionadas a essa DRECAP. O equivalente atual das DRECAPs são as Diretorias Regionais de Ensino, vinculadas à Secretaria de Estado da Educação. Na época, professores do mais alto gabarito (por exemplo, Stela C.B. Piconez, Denice Bárbara Catani, Elza Nadai, Jair Militão Silva, Manoel Oriosvaldo de Moura, Martha Carvalho, Myriam Krasilchik, Nídia Nacib Pontuschka, Noemi Carvalho Neves, Olga Molina e Waldir Cauvilla) participaram da análise dos planos de ensino de vinte e seis escolas que possuíam HEM. Em relação à análise dos planos de Didática e Estágios Supervisionados Piconez E CATANI (1986) analisaram oitenta planos de ensino (24 de segunda série; 20 de terceira série; 20 de quarta série e 16 de estágios supervisionados). Quanto à Didática das Ciências, Matemática e Estudos Sociais, observaram que os conteúdos desses planos não apresentavam reflexão sobre o que ensinar e para que ensinar. Os professores eram munidos de habilidades de planejar situações de ensino, independentemente da realidade que observariam em seu local de trabalho, onde muitas vezes só teriam lousa, giz e "saliva", o domínio dos conteúdos específicos e nenhum recurso material ou físico na escola para apoiar seu trabalho. As analistas também questionaram a competência do próprio professor de Didática para tratar desses conteúdos. Segundo as autoras, um indivíduo formado pelo curso de Pedagogia não teria a formação adequada nas diferentes áreas específicas para ensinar "formas de ensinar" essas disciplinas. Consideravam que embora essa competência estivesse estabelecida legalmente, dificilmente uma formação tão variada quanto a que o caso exige, poderia dar-se de maneira satisfatória na prática, seja em um curso de Pedagogia seja em quaisquer outros currículos que se queiram implantar, pelo menos caso se contemplem cursos de Licenciatura de quatro anos. Em Valência, Espanha os futuros professores das séries iniciais são formados na "Escola de Maestros" de nível superior. Lá recebem instrução em Didática Especial onde terão aulas com professores especialistas em de cada área do conhecimento. No caso de Ciências, por exemplo, terão aulas com um professor formado em Ciências e que fez especialização em Didática do Ensino de Ciências 
o que é exatamente o oposto do que ocorre no Brasil, onde se tem um professor generalista que ensina Didática.

KRASILCHIK (1986), ao analisar os planos de Física, Química, Biologia, Programas de Saúde, Biologia aplicada à Educação, Nutrição e Higiene do Pré-escolar, de 25 escolas da mesma DRECAP-3, depreendeu que:

- $\quad$ as grades curriculares, embora apresentassem diferenças, em geral, têm, no primeiro ano e no segundo anos, duas aulas semanais de Física e Química. Após o primeiro ano, Biologia era ministrada sob a forma de Programas de Saúde, Biologia Aplicada à Educação, Nutrição e Higiene no Desenvolvimento do PréEscolar. Ficava compreensível de que era um artifício das escolas para atenderem às exigências legais, mas a programação ficava descontinuada e em alguns casos superposta, principalmente nos tópicos de tópicos da Reprodução e Nutrição;

- nos planos haviam incoerências entre os objetivos propostos a nível geral, que enfatizam a análise do processo de investigação da ciência, e os objetivos específicos e os conteúdos, que denotando uma preocupação maior com a transmissão de informação;

- $\quad$ que as evidências de preocupação com a formação do professor eram praticamente ausentes, pois não foi possível identificar qualquer esforço de integração, ou coordenação, entre as disciplinas ou evidenciar qualquer tentativa de coordenação das disciplinas científicas com as outras disciplinas, notadamente Didática, Prática de Ensino e Comunicação e Expressão. Embora se fizesse referência à relação ciência e sociedade, as propostas de aula não refletiam esse enfoque e, ao contrário, repetiam-se os itens da maioria dos programas de cursos de $2^{\circ} \mathrm{Grau}$, além de poucas menções a visitas, excursões e atividades fora da escola. As metodologias mais presentes nos planos são aulas expositivas, seminários e laboratório.

Como os programas eram compostos de uma concepção tradicional de bom nível, aparentemente a principal meta dessas escolas fosse a preparação, não de professores para as escolas de Ensino Fundamental, mas sim de vestibulandos supostamente competitivos.

Krasilchik (1986) sugeriu, ainda, que o currículo das disciplinas científicas fosse modificado segundo algumas condições de contorno, a saber: abrangência, equilíbrio e continuidade. Esses parâmetros podem ser definidos como:

- abrangência: devem-se considerar os conceitos básicos a serem conhecidos pelos alunos para que possam ter uma visão adequada da ciência, dos processos usados na pesquisa científica e da relação ciência, tecnologia e sociedade.

- $\quad$ equilíbrio: as várias disciplinas devem ser articuladas de forma a permitir que os alunos tenham uma visão balanceada da ciência atual.

- continuidade: as bases do conhecimento científico devem começar a ser estabelecidos desde a escola primária, pois o Ensino das Ciências deve ser um processo contínuo; assim, o professor primário deve estar adequadamente 
preparado para dar essa fundamentação à criança, da qual depende o aprendizado posterior.

Embora essa análise tenha abrangido apenas uma parte das escolas que possuíam HEM (no caso, somente as escolas pertencentes à DRECAP-3), pode-se ter uma idéia sobre essas Habilitações. Na verdade, esses cursos não formavam e nem especializavam os futuros professores. Com o objetivo de diminuir, ou até mesmo de sanar o problema da formação de professores das séries iniciais, foram criados, no Estado de São Paulo, os CEFAMs - Centros Específicos de Formação e Aperfeiçoamento do Magistério pelo Decreto 28.089 de 13/01/1988. A prioridade nos CEFAMs era, conforme o artigo primeiro do citado Decreto, dar prioridade efetiva à formação dos professores de pré-escola até a $4^{a}$ série do primeiro grau e aprimorar a formação dos professores que atuavam na HEM.

Os alunos desses centros estudavam em período integral e recebiam uma bolsa-auxílio. Embora houvesse uma grande preocupação em relação aos estágios supervisionados, muito pouco se avançou quanto ao ensino de Ciências. A preocupação central ainda se direcionava à alfabetização e ao ensino de matemática. O projeto CEFAM, desde sua criação, passou por várias modificações em sua grade curricular mas era, em síntese, apenas uma versão melhorada da antiga HEM.

Infelizmente, desse emaranhado de debates, leis, decretos e resoluções, somadas à sucessão de experiências, ensaios e erros ainda não se estruturou um sistema adequado para uma boa formação inicial do professor para o EF-I.

A última tentativa empreendida pelo governo federal para resolver esse problema histórico materializou-se na Lei 9394/96, que cria o curso Normal Superior com carga horária de 2800 horas cujo objetivo é o de substituir a HEM.

Em dez anos com mais uma aprovação, a da resolução CNE/CP nำ1 de 15 de maio de 2006, provocou-se mais uma reviravolta administrativa dos cursos de Pedagogia: a modalidade Normal Superior passa a ter carga horária de 3.200 horas. Destas, 2.800 horas devem ser destinadas às aulas teóricas em sala de aula, enquanto as demais podem ser direcionadas a estágios e atividades de áreas de interesse específico dos alunos, como Iniciação Científica. A questão aqui não é o fato de se ampliar a carga horária para melhorar a qualidade de um curso. É preciso vincular a teoria com a prática, fato que não ocorre conforme relatado por Pimenta (2005). Embora os cursos de Pedagogia apresentem disciplinas como Metodologia do Ensino de Ciências, Didática do Ensino de Ciências e Prática de Ensino de Ciências com cargas horárias que variam entre 60 a 140 horas, esses cursos são predominantemente teóricos. Não há momentos em que se discuta como deve ser o preparo das aulas ou como vincular essas aulas a realidade dos alunos. 
Os cursos de formação continuada em serviço não suprem de todo as lacunas deixadas pela formação inicial, mas diminuem o distanciamento entre essa diversidade de formações, além de favorecerem a reflexão sobre a prática docente e a integração do professor em seu grupo de trabalho. A possibilidade de freqüentar cursos dentro do horário de trabalho já é configurado como um direito do docente em alguns países da Europa. Como exemplo, pode-se citar Portugal que, embora não seja é um dos países mais desenvolvidos daquele continente, tem nos últimos anos se preocupado com a formação continuada de seus professores (PARDAL \& MARTINS, 2005).

\subsection{A descida ao labirinto e o encontro com o Fauno}

Bélia desce as escadas do labirinto, sempre seguindo a sua fada. Quando chega ao fundo do labirinto, o Fauno é despertado de seu sono profundo e reconhece, em Ofélia, a reencarnação da princesa de seu reino, Moana, a filha da Lua. Fauno percebe o assombro da menina e, para acalmá-la, mostra-lhe outras fadas que traz escondidas em sua algibeira.

$\mathrm{Na}$ ânsia de buscar uma resposta à primeira pergunta que foi respondida durante a sua trajetória ao fundo do labirinto, surgiu outra pergunta na mente da investigadora como as fadas presas na algibeira do fauno e que será a pergunta de pesquisa na qual a investigadora irá se pautar no decorrer desta investigação:

Qual o impacto causado por um curso de formação continuada em Ciências Naturais na prática docente dos professores?

BRANDI \& GURGEL (2002) ressaltam que, apesar da importância de se ensinar tópicos relativos às Ciências da Natureza nas séries iniciais já ser amplamente reconhecida pela comunidade educacional, na prática, o ensino dessas temáticas não tem obtido o sucesso necessário. Esse fato pode ser explicado pela capacitação do professor das séries iniciais brasileiro que, apesar de sua formação polivalente, em geral não esta suficientemente preparado para a condução adequada dos alunos em seu percurso para a compreensão da Natureza. Na maioria das vezes, é através do uso exclusivo do livro didático que ele o faz, sendo bastante comum o trabalho com a leitura de textos que oferecem respostas prontas e questionários, cuja solução é imediatamente encontrada por correspondência direta com os enunciados lidos. Essa metodologia de perfil reprodutivista faz com que as aulas de Ciências Naturais, na escola, acabem tendo um pouco mais de regularidade após os alunos aprenderem a ler e escrever.

Além da falta de capacitação adequada para ensinar as Ciências da Natureza às crianças, o afogamento no mar de metodologias também contribui para a intensificação dos preconceitos e, talvez, esses sejam os grandes motivos para o impedimento da 
transformação do ensino de Ciências nas séries iniciais. Nessa situação, o profissional é tomado por um grande sentimento de insegurança ao decidir sobre qual caminho seguir, como já mostrado na literatura (BIZZO, 1995; BRANDI \& GURGEL, 2002). 
Capítulo 2: Objetivos

O encontro com Fauno e as Fadas 


\title{
2.1. As Fadas que estão na algibeira do Fauno: a pergunta de pesquisa
}

\begin{abstract}
Zs fadas que serviam ao Fauno estavam incumbidas de orientar Ofélia durante a realização das provas pelas quais teria que passar para confirmar ser a princesa do Reino Subterrâneo. Ofélia teria de passar por três provas antes da Lua Cheia, momento em que o Portal de acesso ao Reino Subterrâneo abriria.
\end{abstract}

Assim como as fadas do Reino Subterrâneo orientavam Ofélia no decorrer de sua prova, a investigadora orientou-se pela pergunta de pesquisa apresentada no capítulo que é sua primeira "fada":

Quais mudanças na prática pedagógica de professores das séries iniciais podem ser promovidas em um curso de formação continuada?

Numa tentativa de responder a esta pergunta, foram traçados objetivos de pesquisa que serão as outras duas fadas presentes na algibeira do Fauno.

O objetivo geral desta investigação se pauta pela análise do impacto causado por um curso de formação continuada sobre a prática docente de professores do EF-I. Este objetivo somente será alcançado se outros objetivos mais específicos forem atingidos. Nesta Dissertação, os objetivos específicos voltam-se à investigação:

- das concepções e reflexões de professores do EF-I a respeito do curso de formação continuada ministrado;

- da problematização dos profissionais docentes participantes do curso de formação quanto a sua prática no ensino de Ciências da Natureza para o EF-I. Pretende-se verificar se o curso os conduziu, de fato, à melhora/mudança da prática docente;

- da relação entre o discurso a respeito da própria prática docente em Ciências desses profissionais e os desenhos e relatos escritos sobre as aulas de Ciências dos seus próprios alunos.

Os objetivos apresentados nesta Dissertação estão em consonância com os pensamentos de JOÃO PEDRO DA PONTE (1999) a respeito da investigação em cursos de formação continuada 
para professores:

a investigação não é a recusa da teoria mas a busca de uma permanente articulação entre teoria e prática;

no trabalho investigativo, é decisivo dar especial atenção às fases mais conceptuais e não aos métodos e técnicas;

a própria experiência de investigação deve ser transformada em objecto de análise e de reflexão;

a investigação não deve ser encarada, ela própria, como a solução universal para a formação dos docentes, mas como uma peça de um dispositivo de formação multifacetado e dinâmico. 


\section{Capítulo 3: Revisão da literatura}

\section{A leitura do Livro das Encruzilhadas}


Bfélia recebe do Fauno o Livro das Encruzilhadas. Esse livro a orientará no decorrer da provas por que irá passar.

Uma revisão da literatura bem feita pode ser considerada o ponto de partida para a investigação porque permite conhecer, compreender, avaliar e sintetizar outras investigações realizadas, possibilitando a identificação de novas abordagens, o conhecimento e a avaliação de metodologias de pesquisa, além de ajudar a delimitar o problema da investigação (COHEN \& MANION, 1990; ALMEIDA \& FREIRE, 1997 apud ALFONSO, 2005), o que justifica o nome deste Capítulo, "O Livro das Encruzilhadas". Nesta revisão da literatura procura-se demonstrar as origens históricas do problema da formação dos professores do EF-I e como a formação desses professores em Ciências é abordada na atualidade pelos países europeus que mais influenciam o Brasil nas questões do ensino (Espanha e Portugal), além dos países de língua inglesa.

\subsection{Um dos corredores do labirinto: $O$ Ensino de Ciências das Séries Iniciais.}

Ao consultar o acervo de Teses e Dissertações do CEDOC (período de 1972 a 2002) e das universidades públicas UNICAMP, USP, UFRGS, UFF, UFSCAR, UFBA (período de 2003 a 2007), foi possível traçar um perfil das produções acadêmicas brasileiras sobre formação de professores em Ciências nas séries iniciais do Ensino Fundamental. Chamou a atenção da investigadora os poucos trabalhos acadêmicos relativos à formação de professores das séries iniciais em ciências: das 3977 Teses e Dissertações analisadas, apenas 53 Dissertações abordam a temática, ou seja, apenas 1\% do montante. Este dado revela o abandono e o descaso em que se encontra o ensino de Ciências nas séries iniciais do Ensino Fundamental. Não são somente as políticas públicas inerentes ao ensino fundamental que deixam a formação de professores das séries iniciais em segundo plano. $O$ meio acadêmico também compartilha deste descaso ao privilegiar o Ensino Médio em suas discussões. Isto não é uma novidade: trata-se de um fato histórico, pois, ao longo da história da educação brasileira, o Ensino Médio sempre mereceu mais atenção do que o Ensino Fundamental.

Na Figura 3.1 está apresentado um gráfico que mostra a evolução numérica das produções acadêmicas que abordam formação de professores das séries iniciais ao longo de 30 anos. 


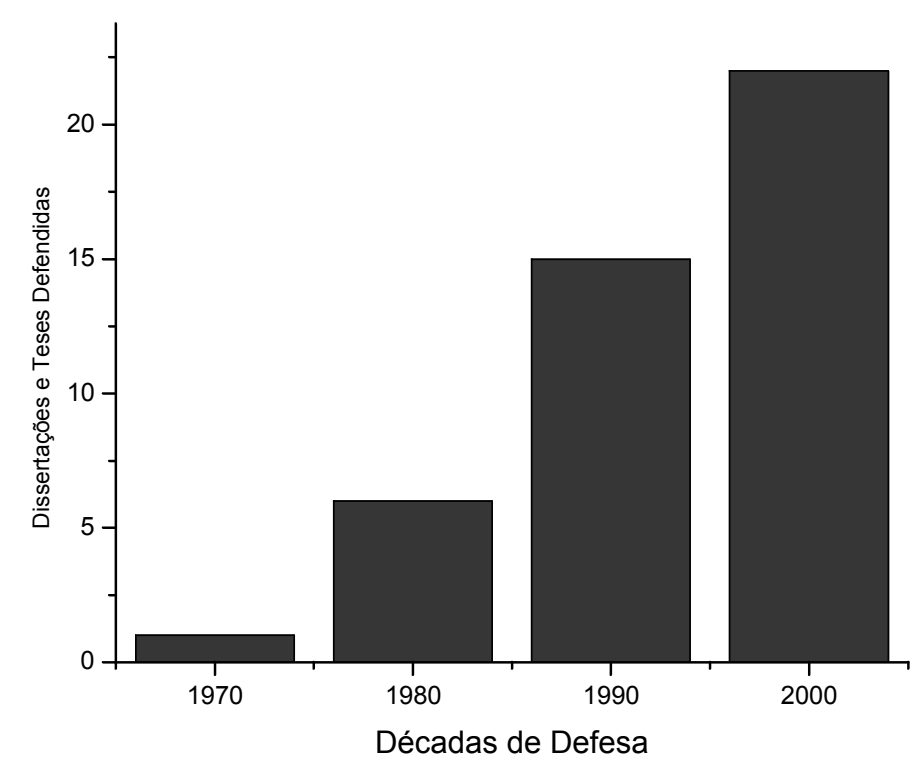

Figura3.1: Dissertações defendidas sobre o tema Formação dos Professores das Séries Iniciais em Ciências.

A análise desse gráfico revela que, ao longo das décadas, houve um crescimento significativo das produções, embora seu número absoluto ainda seja incipiente. Essas produções, assim como as demais sobre ensino de Ciências, não chegam até a comunidade escolar onde foi realizada a pesquisa, conforme relatado por MEGID NETO em 1999:

É voz corrente que as teses e dissertações quase não saem das prateleiras das bibliotecas ou dos armários de seus autores e respectivos orientadores [...].

....mesmo aqueles que participaram da pesquisa ....como por exemplo os professores, os diretores e os alunos, nem sempre lhes é garantido o acesso ao trabalho final.

Os motivos pelos quais as discussões acadêmicas sobre ensino de Ciências não chegam até os professores da Educação Básica e as possíveis soluções para este impasse merecem ser discutidos com profundidade e em outro trabalho. Entretanto, não poderíamos deixar de comentar que esta temática merece uma atenção melhor, pois enquanto não houver um olhar mais atento ao Ensino Fundamental e, principalmente, aos professores que atuam nas séries iniciais desse nível de ensino, pouco adiantará realizar trabalhos de pesquisa voltados para a melhoria do Ensino Médio, pois os alunos das nove séries iniciais estarão fadados a falhas e problemas de formação tão graves que os três anos finais da Educação Básica não serão suficientes para suprir essa deficiência. Estamos em pleno século XXI e o ensino de Ciências para as séries iniciais ainda é um universo a ser desvendado. 
Ainda no final da década de 1990, se intensificaram estudos sobre a compreensão dos caminhos de apropriação e de elaboração do conhecimento que professores das séries iniciais nos cursos de formação continuada e a concepção de ensino e aprendizagem de Ciências desses profissionais e da evolução conceitual da prática pedagógica destes professores. Esta tendência de pesquisa continua pela década de 2000. Pode-se citar como exemplos, a Tese de RABONI (2002) e Dissertações defendidas por SILVA (2006), BRAGA (2005), LACANALLO (2005) e GUIDO (1996).

SILVA (2006) investigou as concepções de ensino e aprendizagem de futuras professoras acerca do Ensino de Ciências através de um curso de formação continuada que teve como base metodológica o Projeto Mão na Massa. O curso, ministrado a 7 alunas durante um ano, com carga horária de 100 horas (75 horas em encontros quinzenais de 5 horas e 25 horas de atividades extra-classe como pesquisas, leituras e estudos dos textos). Os encontros favoreceram a evolução conceitual das alunas a respeito do ensino e aprendizagem de Ciências para crianças, uma vez que as concepções iniciais desses professores eram a do ensino por transmissão-recepção e eles chegaram a evoluir para a concepção de ensino espontaneísta. Tal resultado permitiu que SILVA (2006) chegasse às seguintes conclusões: os encontros de formação continuada de professores não podem se limitar a fornecer conhecimentos conceituais e metodológicos de uma disciplina sem a devida reflexão (o que ensinar, como ensinar e para que ensinar). O professor formador também deve refletir sobre a prática e as concepções que os professores já possuem e o curso deve favorecer o diálogo entre o professor formador e seus alunos e dos alunos entre si. Os futuros professores, além de terem a compreensão da necessidade dos saberes acadêmicos, pedagógicos e integradores, devem ter acesso a inovações didáticas para que possam estar capacitados e seguros para lecionarem de acordo com as solicitações da comunidade escolar e da sociedade em geral.

A investigação de BRAGA (2005) se deu através de duas entrevistas realizadas em dezembro/2004 e janeiro/2005 com duração de 40 minutos com cada entrevistado. A primeira entrevista, contou com 8 professoras da rede municipal de ensino (presume-se que de São Carlos) foi o piloto do projeto. Essa entrevista, segundo o investigador, foi improdutiva e serviu para que ele ficasse mais experiente para realizar outras entrevistas. $\mathrm{Na}$ segunda entrevista, que ocorreu com 2 professoras da rede particular de ensino, o investigador elaborou questões semi-estruturadas e apresentou um caso de ensino. $O$ material foi gravado em áudio e, posteriormente, foi transcrito. A categorização foi de acordo com as cinco categorias de saberes propostas por Tardiff (2002): saberes profissionais, disciplinares, curriculares, experienciais e a relação dos professores com os seus saberes. Percebeu-se a valorização dos saberes experienciais, a utilização de revistas, de livros 
didáticos e sítios da Internet como fontes de aquisição dos saberes disciplinares. Acerca dos saberes experienciais, Braga depreendeu que os professores não conseguem enxergar a influência direta de sua formação inicial na sua prática cotidiana, embora reconheçam o caráter dinâmico das Ciências, não a considera uma criação humana e transformadora de visões de mundo. Braga acredita que o coletivo, se bem orientado, pode constituir-se em uma importante via de formação contínua, pois é uma importante ferramenta para estimular a reflexão sobre sua prática cotidiana, por favorecer condições para a ressignificação dos saberes oriundos de variadas fontes externas.

A Dissertação de LACANALLO (2005) teve como principal objetivo identificar a concepção de professores das séries iniciais do Ensino Fundamental (formação continuada) e de egressos do curso de Pedagogia (formação inicial) sobre o processo ensino e aprendizagem de Ciências Naturais. O estudo se deu através da aplicação de questionário composto por oito questões abertas. Participaram dessa pesquisa 30 professores das séries iniciais do Ensino Fundamental e 30 alunos do último ano do curso de Pedagogia de uma universidade pública. Os docentes possuíam pelo menos três anos de tempo de serviço em uma das quatro séries iniciais. O questionário, composto de questões referentes ao ensino e à aprendizagem de Ciências, foi elaborado de forma a possibilitar a identificação de elementos teóricos e práticos do processo de aquisição de conhecimentos científicos escolares. Tais questões foram antecedidas por perguntas gerais sobre o perfil profissional dos sujeitos: tempo de atuação, formação, cursos realizados, entre outras. Os questionários foram preenchidos em horário de trabalho ou de aula dos sujeitos da amostra. Durante a aplicação, os sujeitos foram informados sobre as normas de preenchimento do material. A análise desses resultados acerca do que os professores entendem sobre o ensino de Ciências foi conforme proposto por AMARAL (1998 apud LACANALLO, 2005). Os resultados revelaram que a maioria dos professores apresenta distanciamento e contradição entre o pensar e o ensinar Ciências Naturais sugerem a presença de diferentes tendências pedagógicas na descrição do seu processo de ensino e mostram que a confusão conceitual manifestada pelos acadêmicos e professores dificulta a implantação e consolidação das mudanças necessárias no ensino de Ciências.

RABONI (2002) procurou apreender os processos de elaboração das atividades práticas no ensino de Ciências por professoras das séries iniciais, levando-se em conta a inferência do pesquisador sobre o trabalho dessas docentes. Participaram dessa pesquisa grupos de 8 a 10 professoras de uma mesma escola e, nas reuniões, desenvolveram-se sete das 10 atividades programadas. Os encontros consistiam em realização de atividades experimentais sobre o tema luz. Foram abordadas atividades tais como: construção de câmera de orifício, teatro de sombras, uso da lupa, microscopia, laser, jogo com espelho 
semi-refletor. As professoras também assistiram a um filme sobre o tema Luz. As atividades foram gravadas em vídeo e as fitas ainda não transcritas foram digitalizadas e gravadas em CD no padrão MEPG. Metodologicamente, os princípios do paradigma indicitário , discutidos por Carlo Ginzburg (1989) , guiaram o pesquisador na busca dos indícios dos processos de elaboração de sentidos, no discurso das professoras. Através do material coletado, o pesquisador analisou os movimentos discursivos ao grupo ao longo do trabalho realizado. Os conceitos de mediação, internalização e drama segundo o modelo histórico-social desenvolvido pelo grupo de Lev S. Vygotsky e os conceitos de polifonia, polissemia e de gêneros de discurso de Mikhail Bakthin, foram utilizados para compor o corpo de análise.

Raboni concluiu que há um caráter contraditório no ideário das professoras a respeito das atividades práticas que são valorizadas, mas quase ausentes no preparo de suas aulas, o que aponta a necessidade de reestruturação das formas de uso dessas atividades em sala de aula e na formação de professores.

GUIDO (1996) investigou em sua Dissertação a evolução conceitual da prática pedagógica do professor de Ciências das séries iniciais. Num primeiro momento, realizou uma entrevista com a pedagoga, que desejava modificar suas aulas de Ciências onde deixou transparecer que ela não conseguia construir nem o projeto pedagógico e nem o planejamento de suas aulas, transcritos do Programa de Primeiro Grau para a $4^{\mathrm{a}}$ série produzido pela Prefeitura do Município de São Paulo (1985), que preconizava o diálogo entre o professor e o aluno e do aluno entre seus pares. Esse primeiro diagnóstico serviu para a professora se conscientizar de seus problemas e de suas soluções. A pesquisadora auxiliou a professora a construir a sua linha pedagógica em Ciências, caracterizando o trabalho advindo dessa pesquisa como uma pesquisa-ação. Foram preparadas 16 aulas com duração de 50 minutos cada uma para os alunos dessa professora que, posteriormente foram gravadas em áudio. Esses registros serviram para orientar as reuniões realizadas entre a pesquisadora e a professora e de ponto de apoio para as aulas subseqüentes. Guido depreendeu que:

- o ensino ministrado não apresentava um eixo condutor;

- os conceitos abordados eram estanques e sem desenvolvimento;

- havia uma clara ausência de relações entre conteúdos;

- existia pouca possibilidade de interação;

- inexistia a reflexão por parte dos alunos ou não era encorajada;

- não existia intimidade com o conteúdo por parte da professora.

Com base nesses dados, a pesquisadora elaborou junto com a professora: 
- a introdução, no planejamento, de conteúdos que propiciassem um maior número de relações;

- a utilização e construção de estratégias de ensino compatíveis com a nova abordagem de ensino e com o que se pretende ensinar, enfatizando as interações entre alunos e entre estes e a professora, pelo favorecimento do trabalho a partir de suas déias e representações, sem prejuízo de conteúdo e que favorecessem a evolução conceitual dos alunos.

- atividades que respeitassem o limite entre o conteúdo, idade e série;

- momentos de discussão entre a pesquisadora e a professora com a finalidade de intensificar o grau de conhecimento da professora acerca do conteúdo.

Nesse trabalho, concluiu-se que é importante a interação de um especialista junto a um professor polivalente para discutir sua prática pedagógica, uma vez que o professor sozinho sente dificuldades em aprimorar o seu trabalho. Esse especialista precisa interagir, respeitando as idéias do professor no sentido de não querer mudá-las completamente, mas dando sugestões que criem para a evolução das idéias. Ressaltou-se a importância de se trabalhar o conceito do profissional reflexivo, fazendo com que esse profissional fique seguro da importância de seu trabalho.

Pode-se notar claramente que nesses trabalhos, o problema que emerge é o fato dos professores das séries iniciais não conseguirem aliar a prática do ensino de Ciências à teoria. Pode-se supor que um dos fatores que conduzem a esse problema seja o fato das aulas que experienciaram durante a infância e durante a sua formação inicial para o magistério não valorizarem a atividade experimental. Outro fator é que cursos de formação continuada em Ciências para professores das séries iniciais são praticamente inexistentes e os poucos que são ministrados também abarcam somente a teoria, deixando o professor sem uma referência para ressignificação de sua prática docente. Os demais problemas são conseqüências desse primeiro.

Os artigos que abordam a temática em questão são raros. Versam sobre resistência dos professores das séries iniciais quanto ao ensino de Ciências a seus alunos e sobre sugestões de como motivar esses profissionais em cursos de formação continuada. ZIMERMANN \& EVANGELISTA (2002), relacionam a falta se segurança dos professores à ausência de conteúdos científicos na formação inicial. Segundo essas pesquisadoras, o papel do professor formador de motivar os futuros professores para o aprendizado, desafiando suas concepções sobre ensinar e aprender para facilitar os saltos cognitivos e ajudá-los a entender como suas idéias e concepções podem afetar a aprendizagem em sala de aula. Essa situação foi verificada em 2001 com 30 alunos do curso de Pedagogia da 
UNBN, durante o curso Ciências para o Início da Escolarização. O curso em questão foi dividido em três partes: Epistemologia da Ciência, Ensino de Ciências e planejamento de um Projeto de Ensino de Ciências. A primeira parte tinha por objetivo os alunos analisassem a dinâmica da construção do conhecimento científico e discutissem as origens da Ciência Moderna, através de resenhas e debates sobre vários textos relativos à filosofia da ciência, de caracterizar o valor da Ciência na sociedade e debater a diferenciação entre Ciência e outras formas de conhecimento. A segunda parte, denominada "concepções do Ensino de Ciências", visava à identificação das diferentes tendências epistemológicas que fundamentam o Ensino de Ciências e a reflexão sobre questões relativas ao Ensino de Ciências relacionando-as à prática pedagógica e ao debate sobre as teorias de aprendizagem no contexto do Ensino de Ciências. Nesta parte foram discutidos artigos sobre representação científica nos livros didáticos, mapas conceituais, concepções de alunos, significado de obstáculos epistemológicos na aprendizagem científica, função da História da Ciência no Ensino de Ciências, aprendizagem científica centrada em temas, eventos, problematização e enfoque CTS (Ciência Tecnologia e Sociedade). A conclusão da disciplina culminou com a apresentação dos vários projetos de Ensino de Ciências, elaborados por grupos de três alunos.

Foi respondido pelos alunos um questionário antes do curso e as fitas de áudio e vídeo das aulas foram transcritas e analisadas pelos autores do trabalho, permitindo depreender que :

- para que cursos desse tipo sejam efetivos é necessário que o professor-formador reflita, avalie e planeje todo o semestre mecanismos que ajudem os alunos a se tornarem autônomos na sua aprendizagem;

- o professor-formador reflita muito sobre como melhorar o conteúdo disciplinar dos futuros professores das séries iniciais do Ensino Fundamental,

LIMA \& MAUÉS (2006) relatam a necessidade de modificar o olhar para o ensino de ciências nas séries iniciais no sentido de ter como referência os saberes dos professores e professoras que ensinam Ciências. Deve-se levar em consideração que o ensino de Ciências é complexo e que há dificuldade de integrar vários tipos de saberes por professores polivalentes e que mais que o pleno domínio do conteúdo conceitual é preciso que o profissional tenha segurança ao ensinar, pois o professor polivalente possui um olhar mais integrador do que o especialista. Concordamos com a questão de o professor polivalente possuir um olhar mais integrador que o especialista, mas discordamos que 0 professor polivalente não deva ter domínio conceitual para ensinar. Pode um profissional ter segurança em ensinar sem ter domínio conceitual do tema que irá abordar? 
Esses são alguns dos trabalhos encontrados no Brasil a respeito do Ensino de Ciências nas séries iniciais e sobre a formação de professores. Fica claro que há uma preocupação muito grande com a evolução conceitual desses profissionais seja ela de conceitos relativos às Ciências Naturais, seja quanto à ressignificação de sua prática docente. Como já foi dito anteriormente, há muito que ser explorado.

\subsection{O ensino de Ciências para crianças no contexto europeu}

No contexto europeu, a formação inicial do professor incide de forma direta ou indireta na forma como o educador tratará o conteúdo em sala de aula. Para compreender o Ensino de Ciências europeu, é preciso conhecer a estrutura da Educação Básica desse continente que está dividido em dois níveis obrigatórios de ensino: o Ensino Primário e o Ensino Secundário Geral. Esses níveis referem-se a três ciclos de formação: o primeiro ciclo, que corresponde ao Ensino Primário, atende crianças de 6 a 10 anos, o segundo ciclo, chamado também de Ensino Secundário Inferior, atende jovens de 11 a 16 anos e o terceiro ciclo, que é o nível Secundário propriamente dito, que atende jovens de 17 a 19 anos (EURYDICE,2006). Hoje, o sistema brasileiro também corresponde a 12 anos de formação básica, Fundamental e mais três anos finais que correspondem ao Ensino Médio. A faixa etária de início dos estudos na Educação Básica são as mesmas tanto da Europa.

O Ensino de Ciências Naturais é abordado como único no $1^{\circ}$ ciclo e como disciplinas distintas a partir do Ensino Secundário Inferior (química, física e biologia), e, de acordo como o EURYDICE (2006), nos documentos oficiais de diversos países consta a orientação de que haja no conteúdo programático atividades que envolvam experimentação científica e investigação. Para que isto realmente ocorra, o documento declara que os professores devem conhecer as diferentes abordagens de ensino de Ciências e sua história em conjunto. Deve-se respeitar o "senso comum" que as crianças possuem a respeito dos fenômenos científicos e durante a realização das atividades, elas devem ser orientadas para que, gradualmente possam ressignificar os conceitos. A tabela 3.1 mostra como está estruturada a educação básica de crianças e jovens no Brasil e na Europa. 
Tabela 3.1: Sistema de ensino brasileiro e europeu.

\begin{tabular}{|c|c|c|c|c|}
\hline \multicolumn{2}{|c|}{ Sistema brasileiro de ensino } & \multicolumn{3}{|c|}{ Sistema europeu de ensino } \\
\hline \multirow{10}{*}{ 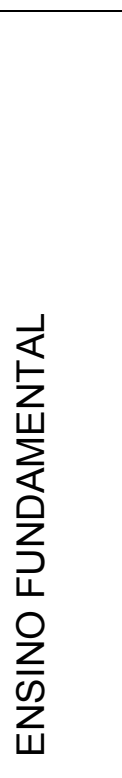 } & $1^{\circ}$ ano & \multirow{13}{*}{ 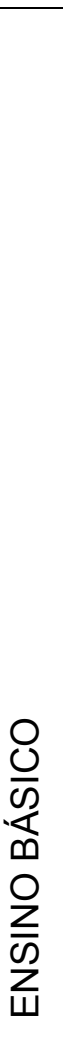 } & \multirow{5}{*}{ 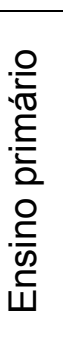 } & \multirow{5}{*}{$1^{\circ}$ Ciclo -6 aos 10 anos } \\
\hline & $2^{\circ}$ ano & & & \\
\hline & 30 ann & & & \\
\hline & & & & \\
\hline & $4^{\circ}$ ano & & & \\
\hline & $5^{\circ}$ ano & & \multirow{8}{*}{ 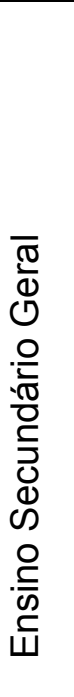 } & \multirow{5}{*}{$2^{\circ}$ Ciclo -10 aos $15 / 16$ anos } \\
\hline & $6^{\circ}$ ano & & & \\
\hline & $7^{\circ}$ ano & & & \\
\hline & $8^{\circ}$ ano & & & \\
\hline & $9^{\circ}$ ano & & & \\
\hline \multirow{3}{*}{ 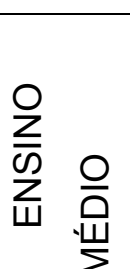 } & $1^{\circ}$ ano & & & \multirow{3}{*}{$\begin{array}{l}3^{\circ} \text { Ciclo }-15 / 16 \text { aos } 18 / 19 \\
\text { anos }\end{array}$} \\
\hline & $2^{\circ}$ ano & & & \\
\hline & $3^{\circ}$ ano & & & \\
\hline
\end{tabular}

Cabe ressaltar aqui que os professores europeus, mesmo tendo formação generalista, recebem formação prática (estágio) que envolve a realização de projetos do domínio das Ciências. Alguns países incluem, nesta fase da formação do educador, o trabalho experimental. Assim, o futuro professor tem orientações gerais para que possa trabalhar com um mínimo de segurança os conteúdos exigidos pelas orientações advindas dos órgãos que regulamentam a educação pública. Situação essa, muito diferente do Brasil, onde alguns cursos de Normal Superior ou Pedagogia sequer oferecem disciplinas de Didática ou Metodologia de Ensino de Ciências para seus futuros professores.

$\mathrm{Na}$ Espanha, o ensino de Ciências para crianças, de uma forma geral, sempre esteve presente na grade curricular, pois a formação de professores das séries iniciais também sempre tem sido muito discutida através de Congressos dos quais participam educadores de renome (CALVO, 1995). Essa realidade é bastante diferente da situação brasileira, em que a escola de Educação Fundamental e a formação de seus professores eram organizadas de improviso. Esse é um dos fatores para a grande distância dos níveis educacionais de ambos os países. Na Espanha o ensino de Ciências para as séries iniciais ocorre desde 1857 com o ensino de noções para agricultura, ministrada apenas para os meninos. O ensino de Ciências Naturais tal como nos dias de hoje é ministrado às crianças 
espanholas desde 1945. Na década de 60, houve um "boom" de projetos direcionados para crianças de 6 a 14 anos (CALVO, 1995) em decorrência do lançamento do Sputinik e do início da Guerra Fria, já tantas vezes relatados em artigos e Dissertações. O Brasil incluiu o ensino de Ciências para crianças pelos mesmos motivos somente a partir de $1970 \mathrm{com}$ a promulgação da LDB 5692/71 e ainda de forma contraditória, pois ao mesmo tempo em que era obrigatório o ensino de Ciências para crianças, a formação na Habilitação Específica para o Magistério não contemplava o ensino de Metodologia e Didática do Ensino de Ciências aos professorandos

Atualmente, a Espanha tem se preocupado com a questão ambiental e sustentabilidade e esse tema tem sido alvo de constantes debates tanto na formação dos professores para a escola primária (maestros) como no ensino de Ciências para crianças (OEI, 2007; VILCHES \& GIL PeREZ, 2007). Pode-se citar o trabalho de BenAVIDEs et al. (2006) onde se propõe um roteiro curricular de educação ambiental na formação de maestros. Este roteiro, desenvolvido no Centro de Ensino Superior Cardeñal Spíndola, um anexo da Universidade de Sevilha, visa complementar a formação dos professores de Educação Primária e Infantil em relação à questão ambiental. Este trabalho demonstrou melhora das condições dos futuros professores em ministrar educação ambiental para suas crianças e pelo resultado obtido, tem aguardado a oficialização para ser aplicado em toda a rede de formação de professores espanhola.

Além desse trabalho, há o do Grupo Complex da Univesidade Autônoma de Barcelona (U.A.B.) que desenvolve atividades de formação inicial de professores de Educação Infantil também sobre a questão ambiental, só que sob a óptica do paradigma da complexidade. $\mathrm{O}$ paradigma da complexidade é um integrador das perspectivas ética, cognitiva e conativa de aproximação ao mundo em um esquema retroativo gerado de forma dinâmica pela interação com os ditos elementos (BONIL \& PUJOL, 2003 apud BONIL, 2005). Trata-se de uma linha filosófica e ideológica que oferece novos caminhos para a formação de uma cidadania capaz de pensar e construir um mundo mais justo e sustentável, incluindo-se valores éticos, epistêmicos e de ação. Esse grupo tem obtido resultados satisfatórios com professores do Ensino Primário através de práticas que conduzem os participantes à reflexão sobre seu trabalho docente e suas atitudes perante a sala de aula.

Outros trabalhos encontrados referem-se ao que pensam os professores a respeito das atividades práticas em Ciências como o de BARRos et al. (1998) que fizeram uma sondagem acerca das idéias prévias dos professores durante um curso de formação continuada que envolvia o processo de reflexão e reflexão na ação sobre aulas práticas e que tinha por objetivo favorecer a inovação dos trabalhos práticos. O curso, durou três encontros, nos quais participaram 147 indivíduos, distribuídos em quatro grupos: o primeiro com 40 
professores em exercício, o segundo com 34 alunos do $3^{\circ}$ Magistério, o terceiro com 36 alunos dos cursos de Química, Física e Biologia e o quarto com 37 alunos de Biologia inscritos no curso Didática da Biologia. No início da primeira sessão foram planejadas três questões com a finalidade de detectar individualmente as idéias dos professores e alunos participantes sobre as características das atividades práticas: a primeira versava sobre quando se realizam tais atividades, se antes, depois ou durante a explicação da teoria; a segunda questão apresentava três opções de atividades, sendo que na primeira atividade apresentava metodologia utilizada no ensino por descobrimento, a segunda era uma atividade clássica, típica do ensino tradicional e a última uma atividade assimilável por investigação dirigida pelo professor. Os participantes deveriam selecionar aquela que correspondesse à sua prática habitual, se conseguiam ensinar Ciências de acordo com o assinalado e, por último, justificar qual das opções eram mais idônea. Após a resposta individual, houve discussão em um grande grupo e daí foram retiradas as primeiras conclusões.

No segundo encontro foram apresentados materiais concretos aos grupos que consistiam em duas atividades, uma de metodologia tradicional e outra de investigação guiada pelo professor, porém, similares em relação às técnicas experimentais e aos conteúdos conceituais implicados. Devido ao fato dos participantes serem predominantemente oriundos de cursos de Química e Biologia, foram apresentadas atividades práticas e alternativas de Biologia que tinha como tema as a placa bacteriana (bactérias como seres vivos) e outra de Química que versava sobre uma reação química. Para a análise do material foi elaborado um guia que incluía aspectos procedimentais, cognitivos e motivacionais, sendo que este momento deu-se em pequeno grupo onde os membros podiam emitir suas opiniões. No terceiro encontro, a proposta era de que o grupo transformasse uma atividade de metodologia tradicional em uma atividade do tipo investigativa sobre os temas germinação de sementes e velocidade de reação. Durante a observação direta das atividades verificouse se os participantes elaboravam questões partindo de um problema e se destacavam proposta de hipóteses e se o estudante procurava de comprovar suas idéias.

Os docentes em exercício e em formação (50\%) manifestaram que as atividades tradicionais orientadas são as mais utilizadas demonstrando que a investigação didática das Ciências têm sido limitada. Os estudantes de Biologia e recém licenciados majoritariamente se manifestaram neste sentido, sugerindo que a experiência universitária imediata é especialmente tradicional. O resultado positivo do ponto de vista dos pesquisadores é que os consultados valorizam a atividade prática denominada neste estudo de investigativa, demonstrando um posicionamento crítico frente às práticas habituais e uma predisposição positiva ao menos do ponto de vista teórico,de inovar planejamentos. Dentre os aspectos 
mais valorizados na atividade investigativa foram a relação teoria/prática e o papel orientador/diretor do professor nas mesmas durante o desenvolvimento de procedimentos científicos (análise do problema, discussão de resultados...), o que conduziu os pesquisadores a pensar que professores em exercício ou em formação apresentam uma preocupação para que as atividades práticas estejam fundamentadas e sirvam como facilitadoras da aprendizagem de conceitos em consonância com a investigação. Sem dúvida não parecem valorizar ao menos explicitamente, a importância educativa dos procedimentos, tanto em relação à sua incidência na aprendizagem conceitual como o referente ao trabalho científico $O$ reduzido número de professores e alunos que elegeram a atividade por descobrimento, apresentaram uma visão ingênua da aprendizagem considerando que esta se alcança através do trabalho autônomo do aluno.

Neste artigo embora BARROS et. al (1998) tenham se deparado mais com aspectos negativos acerca das aulas práticas de Ciências, concluíram que na formação docente se recomenda a formação de grupos estáveis de trabalho, onde os professores discutam os problemas surgidos em aula em busca de soluções e apontamentos da investigação em didática das Ciências, que são um dos importantes aspectos a contemplar a consecução de mudanças metodológicas mais estáveis de ensino das Ciências.

VIDAL E MEMBIELA (2005) relataram as concepções de um grupo de futuros professores a respeito da germinação de uma semente. Neste trabalho, os autores perceberam que $1 / 4$ dos 53 estudantes de Magistério envolvidos desconhecia o processo de germinação de uma semente. Há também, na Espanha, uma forte influência da corrente CTS, que embora menos intensa, ainda permanece atual.

Em Portugal, há interesse na pesquisa sobre o emprego de novas tecnologias de informação e comunicação (TIC) que favoreçam o desenvolvimento profissional de professores e a aprendizagem e motivação dos alunos (BORGES DA SILVA, 2004). Assim como no Brasil, também aparecem estudos sobre as concepções de professores e alunos sobre temas relativos às Ciências Naturais (DANTAS, 2006), sobre as necessidades dos professores do ciclo básico a respeito das motivações/interesses e carências de formação no âmbito das Ciências Naturais (ALFONSO, 2005). Ainda, foram encontrados artigos que procuravam investigar se o pensamento crítico de professores de ciências causava impacto nas práticas em sala de aula e no nível de pensamento crítico dos alunos (TENREIRO-VIEIRA, 2004), e sobre a formação de professores numa perspectiva CTS (TEIXEIRA, 2003). A respeito deste último: "a formação contínua é a menos desenvolvida em Portugal. O sistema de progressão dos professores na carreira [...] não delimita a natureza da formação. [...]". A carência de oferta de cursos na área da Didáctica das Ciências não tem permitido preencher lacunas na formação dos professores em exercício, onde o ensino das Ciências de 
orientação CTS é um exemplo. Esses pesquisadores espanhóis e portugueses utilizam como referência os trabalhos ingleses e, obviamente, são influenciados por este país.

\subsection{A pesquisa de formação de professores nos países de língua inglesa}

Nos países de língua inglesa, de um modo geral, a formação continuada em Ciências de professores do Ensino Primário é vista como ponto chave para a resolução de muitos problemas relativos a essa modalidade de ensino. Geralmente, os formadores são professores com mais anos de carreira, portanto mais experientes no ensino, constituindose um sistema de supervisão (JONES, 2008; AKERSON, 2000). Akerson e colaboradores relatam (AKERSON et al., 2000) investigações sobre como o domínio da disciplina pelo professor interfere na elucidação das idéias dos estudantes e como o professor reage às idéias dos estudantes as quais revelaram que professores com nível de conhecimento mais elevado conseguem motivar melhor os estudantes a compartilhar suas idéias. Ainda, que as idéias dos estudantes são uma boa fonte para melhoria do conhecimento do professor.

Na Austrália, os estudos de HudSON \& Mc HOBLE (2003) apontam que o reforma do Ensino Primário em Ciências há muito tempo já é percebido como um problema. A questão do ensino de ciências para crianças também tem sido discutida como um problema a ser resolvido na Inglaterra (apud LUNN \& SOLOMON, 2000), e nos Estados Unidos (apud NAtional Comission, 1996, Gallagher, 2000). A ênfase nas práticas de Ensino de Ciências é considerada como o ponto chave da reforma educacional no que se refere na formação continuada de professores primários numa concepção moderna de práticas de ensino. $\mathrm{A}$ disciplina Ciências é vista como um componente crítico do acesso necessário para fazer a mudança da realidade em sala de aula.

A prática de ensino tem sido relevante na literatura recente sobre formação continuada em serviço de professores. O sistema de supervisão providencia oportunidades para a formação continuada de professores para ensinar para e com outros e empenhar-se na construção de significados. A supervisão nada mais é do que uma colaboração entre os supervisores (supervisores ou professores colaboradores) e supervisionados (professores em formação continuada), sendo considerado uma via de implementação educacional nas reformas educacionais (HUDSON \& SKAMP, 2002). A eficiência dessa modalidade de formação continuada foi mensurada com um pós-teste com dois grupos de professores concluintes de um curso de formação continuada em serviço. Um primeiro grupo, constituído de 60 pessoas (grupo controle) e outro grupo constituído de 12 indivíduos (grupo de intervenção), ambos de uma mesma universidade. O grupo de intervenção recebeu um programa de supervisão para desenvolver práticas de ensino de Ciências para o nível 
elementar de ensino. Os resultados indicaram que o grupo controle e o grupo de intervenção observaram que as supervisões combinadas a fatores pré-estabelecidos (exemplo: qualidades pessoais, exigências requeridas, conhecimento pedagógico, modelos de formação e feedback) nas práticas de Ciências foram estatisticamente significativas para os primeiros quatro primeiros fatores. Arguiu-se que a experiência de supervisão especializada designada para o desenvolvimento de aspectos específicos da ciência primária tem o potencial para acentuar o grau de qualidade das experiências de ensino e da formação profissional.

ZEMBAL-SAUL et al. (2000), ao realizar um estudo de caso sobre a representação do conteúdo de Ciências por dois professores da escola elementares que cursavam o primeiro ano de um programa de formação continuada experimental que tinha por base o tema "o que há na sua água?", coletaram várias informações tais como: entrevistas gravadas em áudio, documentos escritos e vídeo tape sobre episódios de ensino. Foram solicitados aos professores dois ciclos completos de planejamento, ensino e reflexão. As informações foram analisadas por sua seqüência, exatidão e coerência, assim como sua atenção às necessidades da aprendizagem dos alunos. Houve melhoras na representação do conteúdo, que foram apontadas dentro de cada componente solicitado. As mudanças mais evidentes foram a compreensão cuidadosa relacionada aos processos de aprendizagem dos alunos. Os resultados sugerem que houve melhoras no conteúdo dos ciclos de instrução produzidos pelos professores.

Percebe-se que, de certa forma, o estudo de concepções de professores sobre Ciências. Países europeus e de língua inglesa abordam com mais intensidade esta temática porque há um consenso de que o profissional que trabalha com crianças deva ser o mais bem preparado. O Brasil ainda caminha nesta proposta devido a cultura que se instalou de se priorizar o Ensino Médio em todos os sentidos e que de certa forma vai se levar algum tempo para mudar este estado de coisas.

Assim, percorremos o labirinto da formação dos professores em ciências das séries iniciais e concluímos que no Brasil as pesquisas ainda são incipientes sendo é necessário que mais pesquisadores se sintam motivados a pesquisarem o tema, pois Ciências é linguagem. E o ensino de Ciências, conforme bem lembrado por Bızzo (1995), estimula o desenvolvimento da linguagem e a capacidade de argumentação das crianças, tão carentes em nosso país de atividades que priorizem essas competências por falha na formação inicial de seus professores. Ao longo da História, nem sempre a formação de professores é valorizada como deveria. As falhas e os problemas incidem diretamente na formação das crianças e jovens, pois a insegurança em relação aos conteúdos e à metodologia incide de forma direta na formação das crianças e jovens. A falta de uma estruturação curricular séria 
para que de fato sirva de base de sustentação para outras formações que virão após a formação inicial tem gerado profissionais com qualidade de muito baixa e que mal conseguem ensinar fatos elementares para os seus alunos. A seguir o panorama histórico da formação de professores do Estado de São Paulo mostrará que o problema da formação vem de muito tempo atrás...

\subsection{A primeira Escola Normal Paulista (Brasil Monárquico - 2ª metade do Século $X I X)$}

As iniciativas pertinentes à formação de professores foram implementadas pelos movimentos da Reforma e Contra-Reforma (séc XVI) e defendidas por Comenius, no século XVII ampliando o acesso da população à educação pública; essa institucionalização prospera no seio das idéias liberais de secularização e extensão do ensino primário a todos os extratos sociais, atingindo seu ápice no âmbito da Revolução Francesa (1792). Nessa ocasião, esse processo se concretiza pela criação de Escolas Normais, destinadas a formar professores leigos, sob a responsabilidade do Estado. Com a consolidação dos Estados Nacionais (séc XVII ao XIX) e a implantação dos sistemas públicos de ensino, multiplicaramse as Escolas Normais (TANURI, 2000), um enorme acréscimo à primeira escola destinada à formação de professores, atribuída a São João Batista de La Salle que, em 1684, em Reims, fundou o "Seminário dos Mestres" (DUARTE, 1986 apud SAVIANI, 2005).

Em 1759, com a expulsão dos jesuítas dos domínios portugueses pelo Marquês de Pombal, as escolas, vinculadas aos interesses da Igreja, foram substituídas por unidades voltadas aos interesses do Estado. No Brasil, as políticas pombalinas objetivavam a intensificação da produção comercial, daí o interesse em libertar os índios dos padres e torná-los integrados à economia, como mão de obra escrava ou não. Por outro lado, o ensino público em nosso país encontrava-se em meio ao caos e não havia, por parte do Império brasileiro, interesse no ensino das primeiras letras (CUNHA, 1986 apud ZOTTI, 2006). Essa falta de interesse institucional pelo ensino está associada ao tipo de economia predominante à época: latifundiária, agroexportadora e escravista, que prescindia de pessoas letradas para execução do trabalho (ZOTTI, 2006).

Com a crise da produção açucareira (séc XVII), desenvolveram-se outras atividades no Brasil, como a mineração, colaborando indiretamente para o crescimento de atividades econômicas complementares: a produção de alimentos, de manufaturas relacionadas ao setor têxtil e do ferro. A urbanização se intensificou e surgiu uma classe média composta basicamente de imigrantes portugueses e de indivíduos que se realizaram economicamente 
através da mineração, que conduz essas pessoas a novas necessidades de consumo e de formação (SODRÉ, 1996 apud ZOTTI, 2006).

Apesar do surgimento dessas novas necessidades, não havia uma proposta de educação popular na Colônia e o ensino de primeiras letras surge no Brasil apenas em 1772, com o estabelecimento de algumas aulas de primeiras letras no Rio de Janeiro e nas principais cidades das capitanias. $O$ ensino jesuítico foi substituído pelas aulas régias, que eram aulas autônomas e isoladas ministradas em escolas carentes de um conjunto de estudos ordenados e hierarquizados, como aquele dos colégios jesuítas (ZOTTI, 2006). Essa educação era destinada apenas à formação da elite colonial masculina.

O preparo dos professores no Brasil só adquire força após a Independência, quando surgem rumores sobre a organização da instrução popular. A primeira lei geral brasileira relativa ao Ensino Primário (Lei das Escolas de Primeiras Letras), aprovada em 15 de outubro de 1827, estabelecia que a instrução dar-se-ia segundo o método do ensino mútuo (lancasteriano) e que os professores deveriam ser treinados nesse método nas capitais das respectivas Províncias, a custa dos próprios ordenados. Essa lei não se efetivou devido à falta de professores qualificados, remuneração adequada e fiscalização, dentre diversas outras causas (MOACYR, 1936 apud SAVIANI, 2005; MARCÍLIO, 2005; ZOTTI, 2006). Pode-se notar que a incompetência ou o descaso dos governantes quanto à organização de uma educação laica e popular no Brasil não é recente.

Com a descentralização instituída pelo Ato Adicional à Constituição Imperial de 1823 (aprovada em 1834), o Ensino Elementar foi atribuído às Províncias, que também deveriam cuidar da formação dos seus professores. A situação do ensino de primeiras letras agravase, pois essas Províncias careciam de recursos para bancarem as despesas da educação, caracterizando desde então a omissão do poder público no que se refere à educação pública (ZOTTI, 2006; SAVIANI, 2005).

O interesse em se criar uma Escola Normal no Brasil surge a partir do momento em que começam a faltar professores para atender as necessidades educacionais das elites, uma vez que os professores de primeiras letras, nessa época, sabiam um pouco mais que seus alunos e, como foi dito anteriormente, não recebiam qualquer apoio dos governantes (TANURI, 2000; PENIN, 2001). Em São Paulo, a Escola, fundada em 1846, apresentava uma estrutura precária, lembrando mais um mero curso preparatório do que um curso de formação inicial de professores. O currículo era organizado para ser cumprido em dois anos e apenas um professor lecionava todas as disciplinas: lógica, gramática geral e língua nacional; teoria e prática da aritmética, até proporções; noções gerais de geometria prática; caligrafia; princípios e doutrinas da religião do Estado; e métodos e processos de ensino, 
suas aplicações e vantagens comparativas. Durante seus 21 anos de existência, a primeira Escola Normal formou apenas 40 professores, sendo desativada devido a aposentadoria de seu único professor, Manoel José Chaves, que era bacharel em Direito (MARCílIO, 2005; TANURI 2000).

A segunda Escola Normal da Província de São Paulo surge sete anos após o fechamento da primeira escola. Seu corpo docente, composto por dois professores bacharéis, inexperientes em Didática, veio a encerrar suas atividades em 1878, por ordem do Presidente da Província, que se justificou com o aperto do orçamento. Em uma tentativa de restauração, o Presidente da Província de São Paulo, Laurindo Abelardo de Britto (diplomado pela primeira Escola Normal e bacharel em Direito) inaugura a terceira Escola Normal em 1880. Seu currículo era desenvolvido em três anos e constituía-se de cinco cadeiras (correspondentes às disciplinas dos dias de hoje; TANURI, 2000; MARCíLIO, 2005).

Entretanto, alguns Presidentes de outras Províncias e inspetores de Instrução rejeitavam as Escolas Normais como instrumento para qualificação de pessoal docente devido a seu desprestígio e aconselhavam, por ser mais econômico, o sistema de inspiração austroholandês dos "professores adjuntos", que empregava os melhores alunos como aprendizes, auxiliares dos professores já experientes, preparando-os para lecionar de maneira totalmente prática.

Nesse período final da Monarquia, um dos grandes problemas na formação dos professores das séries iniciais era a escassez de uma bibliografia pedagógica brasileira, pois mesmo as traduções eram raras, situação que retrata a formação profissional deficiente das Escolas Normais. Ainda nos dias de hoje, valorizamos muito pouco os pedagogos brasileiros, como, por exemplo, Paulo Freire, e ficamos na dependência de pedagogos estrangeiros. Atualmente, o nosso sistema educacional, sobretudo o paulista, acaba sendo uma cópia muito mal feita dos sistemas educacionais europeus, sem adequação a nossa realidade.

Ainda na segunda metade do século XIX, o Positivismo começa a ser disseminado no Brasil, marcado por ideais republicanos, pelo liberalismo político e pela luta para a abolição dos escravos, pelo ecletismo e pela ascensão de uma burguesia urbana que vai ser decisiva na transição Império-República. Essa nova camada social era composta, em parte, de intelectuais brasileiros: jornalistas, escritores, tribunos, professores, militares e religiosos que, influenciados pelas diversas formas de pensamento oriundas dos grandes centros europeus (França e Inglaterra) e da América do Norte (Estados Unidos), desejavam colocar o país, através dessas novas idéias, em sintonia com o moderno espírito científico pois acreditavam que a ciência e a cultura haveriam de civilizar o Brasil, através de uma geração 
científica. Os "intelectuais" de São Paulo, Antonio Silva Jardim, Cipriano José de Carvalho e Godofredo José Furtado, modificaram a estrutura da formação do professor primário, valendo-se mais dos aspectos culturais e pedagógicos do positivismo, concentrando interesses na mudança de costumes e no preparo mental da sociedade para adequação ao novo tempo da Ciência (PAIXÃO, 2000 ; MARCílIO, 2005).

\subsection{As Escolas Normais Paulistas da República Velha (1889 a 1930)}

Para o ensino de Ciências Naturais é necessária a construção de uma estrutura geral da área que favoreça a aprendizagem significativa do conhecimento historicamente acumulado e a formação de uma concepção de Ciência, sendo necessário considerar as estruturas de conhecimento envolvidas no processo de ensino e aprendizagem - do aluno, do professor, da Ciência. (BRASIL, 1997,p.27).

Sem professores bem preparados, praticamente instruídos nos modernos processos pedagógicos e com cabedal científico adequado às necessidades da vida atual, o ensino não pode ser regenerador e eficaz.

(Decreto $\mathrm{n}^{\circ} 27$ de 12 de março de 1890).

Após a Proclamação da República, as províncias foram elevadas à categoria de Estados federados. Em São Paulo, inicia-se uma ampla reforma da Instrução Pública, baseada na promulgação do Decreto $\mathrm{n}^{\circ} 27$ de 12 de março de 1890 (TANURI, 2000; SAVIANI, 2005 MARCílIO, 2005). Rangel Pestana, ao reformular a Instrução Pública do Estado, declarava: "Todo o aperfeiçoamento da instrução será impossivel se não tivermos bons mestres e estes só poderão sair de Escolas Normais organizadas em condições de prepará-los" (REIS FILHO, 1995 apud SAVIANI, 2005). Apesar dos apelos por uma educação popular, ainda predominava a educação acadêmica e aristocrática, reflexo da estrutura da sociedade. Os interesses da elite latifundiária, atendidos nos primeiros anos da República (política do cafécom-leite) e as atividades econômicas na agricultura não careciam de uma população escolarizada (ZOTTI, 2006).

São Paulo antecipou-se à Reforma Federal de Benjamin Constant (Decreto no 981 de 8 de novembro de $1890^{1}$ ) por intermédio de Caetano de Campos e Gabriel Prestes que lideraram a Reforma Paulista de 1890 (Lei 27, de 12/03/1890, alterada pela Lei 88 de 8/09/1892 e reformulada, em 7/08/1893, pela Lei 169) que previu a criação de quatro Escolas Normais em todo o Estado, mas, na prática, no início, funcionou apenas a da

\footnotetext{
${ }^{1}$ Esta Reforma foi a única que contemplou o ensino primário, dividindo-o em categorias: $1^{\circ} \mathrm{Grau}$ (7 a 13 anos), $2^{\circ} \mathrm{Grau}$ (13 a 15 anos). Havia uma preocupação metodológica que pode ser confirmada pela leitura do artigo $3^{\circ}$ $\S 2^{\circ}$ : "Em todos os cursos será constantemente empregado o methodo intuitivo, servindo o livro de simples auxiliar, e de accordo com programmas minuciosamente especificados" (BRASIL, 1890, p. 3476). A proposta de Benjamim Constant, foi criticada até mesmo pelos positivistas porque o modelo pedagógico de Comte não previa a introdução de estudos científicos para meninos menores de 14 anos. As idéias do reformador eram consideradas uma ameaça à formação da juventude e aos padrões da sociedade aristocrática rural e, na prática, o Ensino Primário ficou restrito à escrita, leitura e cálculo. Outras reformas se sucederam na Primeira República mas esse nível de ensino não foi contemplado. Permaneceu a concepção do ensino elitista do Império que priorizava os Ensinos Secundário e Superior. (ZOTTI, 2006)
} 
Capital. Essa Reforma verticalizou os níveis de escolarização, que se iniciava aos 4 anos de idade, no jardim-de-infância, e estendia-se até os 18 , em escolas de $1^{\circ}$ e $2^{\circ}$ graus (correspondentes, hoje, ao Ensino Básico: conjunto dos Ensinos Fundamental, EF, e Médio, EM).

A nova Escola Normal, em sua primeira organização, foi concebida por Caetano de Campos com dois cursos: o preliminar, ou Escola Normal primária, e a Escola Normal secundária, de quatro anos de estudo, que deveria preparar os profissionais para atuarem na escola fundamental pública, universal, gratuita, obrigatória e leiga e para ambos os sexos, idealizada por ele. Pela primeira vez na História brasileira o magistério foi profissionalizado, distinguindo-se de outras carreiras, tendo implicado na melhoria do preparo do professor primário porque a formação passou a ser um critério básico para o ingresso na carreira, resultando na queda do número de professores leigos (MARCíLIO,2005).

O programa de estudos, agora reformulado, tinha por base o enriquecimento dos conteúdos curriculares e a prática de ensino. Caetano de Campos, como diretor da Escola Normal, foi incumbido de promover a reforma e descreveu as novidades ao governador do Estado, em 1891, através de um relatório:

Novas cadeiras foram criadas. Às matemáticas juntou-se o estudo da álgebra e escrituração mercantil; às ciências físico-químicas adicionaram-se as ciências biológicas; o estudo da língua materna foi ampliado; e a parte artística profundamente modificada no estudo do desenho, foi alargada com a cadeira de música (solfejo e canto escolar); a educação física foi criada com as aulas de calistenia, ginástica e exercícios militares; finalmente, a geografia foi separada da cadeira de história, para maior latitude do ensino; $e$ as ciências sociais contempladas com o acréscimo da cadeira de economia política e educação cívica, na qual se dão noções de direito e de administração (Reis Filho, 1995 apud Saviani, 2005).

Pelos relatos, pode-se notar que Caetano de Campos era um homem visionário não somente pelas reformas que fez, mas, também, por sonhar com um curso normal superior na capital. Essa idéia tomou forma na Lei no 88 , de 1892, prevendo um curso superior anexo à Escola Normal, que não funcionou (TANURI, 1979 apud EVANGELISTA, 2001).

Em várias Províncias, as órfãs institucionalizadas eram destinadas ao magistério, pois, então, os cargos no ensino primário eram preenchidos a custo de salários miseráveis. Essa feminilização do magistério é responsabilizada pelo desprestígio social e pelos baixos salários da profissão (SCHNEIDER,1993 apud TANURI, 2000; TAMBARA,1998 apud TANURI, 2000).

Gabriel Prestes ao assumir a Escola Normal em 1894, após o falecimento de Caetano de Campos, introduziu a metodologia norte-americana, como sugerido por Horácio Lane, que intermediou a compra do material escolar de que carecia a Escola Normal nos Estados 
Unidos, além de indicar-lhe pessoal para lecionar novas matérias. Foram criadas três Escolas-Modelo (Escolas-Modelo da Escola Normal da Praça da República, da Luz e Maria José, que existe até nos dias de hoje e é localizada no bairro da Bela Vista). Essas escolas tinham a função de garantir a prática de ensino dos normalistas através de estágios de observação e do treino de prática de ensino, atividades que dificilmente ocorriam. Em 1913, o Movimento da Escola Nova é introduzido em São Paulo, através de Oscar Thompson e José Ribeiro Escobar e a matéria Psicologia Experimental é anexada à cadeira de pedagogia na Escola Normal.

Na década de 1920, Sampaio Dória comanda a segunda grande reforma do ensino em São Paulo, instituindo a escola primária alfabetizante de dois anos obrigatórios e gratuitos, além da equiparação das Escolas Normais, extinguindo a Escola Normal primária. Conseqüentemente, eleva-se o nível de formação do corpo docente, caracterizando um retorno aos padrões defendidos por Caetano de Campos (MARCílIO, 2005).

Sampaio Dória, inspirado nos moldes da Escola Normal Superior da França, se esforçou em criar uma Faculdade de Educação, que não foi concretizada. Criou apenas um Curso de Aperfeiçoamento na Escola Normal da capital que se tornou mais tarde o Instituto Pedagógico de São Paulo (Evangelista, 2001; Penin, 2001).

No ano de 1926, houve uma crise de falta de candidatos ao magistério em São Paulo, devido ao elevado custo de vida e ao preço do café. Normalistas recém-formados preferiam empregar-se nos bancos, comércio e indústria por oferecerem melhores condições e vantagens financeiras, provocando déficit de professores para regerem as classes livres. $O$ governo contornou essa situação rebaixando a duração do curso normal para três anos através do Decreto-Lei 2.269 de 31/12/1927. A formação de professores por escolas normais municipais e particulares passa a ser rápida e em grande quantidade, provocando o decaimento da qualidade de formação desses profissionais a ponto da iniciativa privada contratar professores despreparados para formar aqueles que seriam os futuros professores do ensino de base. Apenas a escola Normal da Praça manteve seu curso em cinco anos (MARCílIO, 2005). Posteriormente, a crise mundial de 1929 desencadeia no Brasil a crise cafeeira, obrigando os latifundiários cafeicultores a dividirem o poder com a classe burguesa emergente, desencadeando na reorganização dos aparelhos repressivos do Estado e na ascensão de Vargas ao poder em 1930, apoiado pelos tenentes e pela classe burguesa. Pela primeira vez, é criado um Ministério da Educação e Saúde que foi o ponto principal para mudanças substanciais na Educação (FREITAG, 1986).

\subsection{A Escola Normal Paulista da República Populista (1930-1964)}


A Revolução de 1930 questionou o modelo agrário-comercial exportador de economia que mantinha o Brasil dependente da importação de produtos manufaturados e submisso aos países desenvolvidos. Enquanto nas três primeiras décadas do século $X X$ as nações industrializadas alcançavam o capitalismo na fase imperialista, as nações subordinadas passaram por graves crises e eram praticamente dependentes dos países desenvolvidos. No Brasil, são atacadas duas causas do subdesenvolvimento: a política econômica dirigida para o setor agrícola e a dependência em relação à economia externa (ZOTTI, 2004 apud ZOTTI, 2006).

O desenvolvimento industrial entrou na sua segunda etapa exigindo novas formas de produção e novas necessidades: percebeu-se que o povo necessitava de um mínimo de instrução e de qualificação para trabalhar como operários em fábricas ou para exercer atividades comerciais. A urbanização também exige uma escolaridade mínima dos indivíduos pois o estilo de vida da cidade é bem mais complexo do que aquele do campo. Essa política do nacional desenvolvimentismo é caracterizada pelo Estado centralizador das decisões da política econômica, o que irá influenciar a educação também, com o surgimento de diversas normas, decretos, debates, congressos, fóruns, comissões e propostas de reformas. A educação escolar é considerada pelo novo modelo econômico uma alavanca no crescimento da industrialização/urbanização.

Através do Decreto 4.888 de 12 de fevereiro de 1931, Lourenço Filho instituiu um curso pós-normal que preparava inspetores, delegados de ensino, diretores e professores da Escola Normal. Esse curso pós-normal, instalado no Instituto Pedagógico era um substituto provisório para uma futura escola superior de estudos pedagógicos. Com a duração de dois anos, esse curso mantinha disciplinas como pedagogia geral e história da educação, fisiologia aplicada e psicologia educacional. Seus formandos tinham preferência nas nomeações para o magistério (PENIN, 2001; MARCílIO, 2005).

O Manifesto dos Pioneiros da Educação Nova de 1932 propunha a construção ampla e abrangente de um sistema nacional de educação em todos os níveis, desejava reconstruir a sociedade através da escola socializada. Na concepção dos Pioneiros, a escola seria reconstruída sobre a base da atividade e da produção, pois o trabalho em si mesmo seria o fundamento da sociedade humana e a escola seria o meio em que se restabeleceria entre os homens o espírito da disciplina, solidariedade e cooperação, uma obra social que ultrapassa o quadro estreito dos interesses de classes (GHIRALDELLI JR., 2003).

Fernando de Azevedo deu atenção especial aos professores ao estruturar o código de Educação de 1933. Segundo Azevedo, o candidato ao magistério deveria, em primeiro lugar, cursar a escola secundária, de cinco anos, para depois ingressar no curso de 
formação profissional de dois anos. Esta reforma também contemplou a criação das seguintes escolas e anexos: a Escola de professores, a Escola secundária, a Escola primária, um jardim-de-infância e uma biblioteca. A escola primária, o jardim-de-infância e as classes maternais anexas foram colocados sob o controle da Prática de Ensino (PIMENTA, 1992; MARCíLIO, 2005).

A Escola Normal da capital, agora denominada Instituto de Educação Caetano de Campos, tinha influência dos Teacher Colleges americanos. Ministrava cursos de formação de professores primários, cursos de formação pedagógica para professores secundários, bem como cursos de especialização para diretores e inspetores. Os cursos abrangiam a formação inicial, a formação continuada e a pesquisa. Embora a proposta fosse excelente, mal chegou a ser instituída pois foi seguida pela criação, em 1934, da Universidade de São Paulo e sua Faculdade de Filosofia, Ciência e Letras. Essa Faculdade passou a manter cursos de licenciatura, para preparar os professores para o ensino secundário e normal (EVANGELISTA,2001; PENIN, 2001).

Entre 1946 e 1947, são debatidas e criadas as Leis Orgânicas de ensino, nos níveis secundário e primário (formação geral e profissionalizante), sendo a primeira vez que o Estado intervém na organização da educação brasileira. Em 2 de janeiro de 1946, surge o Decreto-Lei 8530, que traçou objetivos mais definidos para as Escolas Normais de todo o país como: 1. prover a formação do pessoal docente necessário às escolas primárias, 2 . habilitar administradores escolares destinados à gestão das mesmas escolas, 3 . desenvolver e propagar os conhecimentos e técnicas relativos à educação da infância (MARCílIO, 2005; ZOTTI, 2006).

Esse decreto não foi respeitado, pois, em 1950, Adhemar de Barros autorizou a abertura da primeira Escola Normal noturna em Campinas, desencadeando na abertura de uma série de escolas semelhantes. Essas escolas improvisavam os professores das diversas disciplinas com pessoas que não possuíam nenhuma experiência ou qualificação para assumir tais responsabilidades, resultando no rebaixamento acentuado do nível de ensino. Amparado pela lei, qualquer pessoa podia abrir uma escola normal particular, bastando construir ou alugar salas de aula sem nenhuma infra-estrutura.

Em 1957, com a instituição da Lei 3729, que versava sobre a reforma estadual paulista do ensino normal, tentou-se reorganizar a expansão da rede de Escolas Normais, através da criação de exames vestibulares, da fixação do curso normal em três anos, além do estabelecimento de um curso de aperfeiçoamento de mais um ano que poderia ser em: educação pré-primária, ensino primário rural, ensino de deficientes mentais, auditivos ou 
cegos, além de um curso de Administradores Escolares, com duração de dois anos (MARCÍLIO, 2005).

Essa política marcou a década de 1960 em relação à formação de professores com a elevação do número de profissionais mal preparados para um mercado de trabalho saturado. O final desta década culminou mais uma vez com uma formação deficiente do professorado: currículos defasados, número elevado de disciplinas a serem estudadas que não estavam em consonância com os problemas reais da profissão. A metodologia e a prática de ensino ficavam em segundo plano e vários cursos Normais eram abertos sem Colégios de Aplicação, levando à migração dos professorandos para outros estudos de nível superior. Após muitos debates, a LDB 5698/61 não modificou o Ensino Normal, mantendo a duração dos estudos e a divisão dos ciclos de antes, além de deixar a formação do professor primário sob a tutela do Estado e do Distrito Federal (MARCílIO, 2005). Na verdade, o texto definitivo da LDB, sancionado em 1961, tinha seu projeto-de-lei datado de 1948, uma lei tardia e que não contribuiu significativamente para o real desenvolvimento da Educação.

\subsection{O Fim da Escola Normal e o Surgimento da Habilitação Específica para} o Magistério em São Paulo durante a Ditadura Militar (1964-1985)

A Ditadura Militar quis organizar a escola operacional, que preparasse para o trabalho, para o desenvolvimento do país e principalmente, para a segurança nacional. O Decreto 50.133/68 do Estado de São Paulo estabeleceu a duração do Curso Normal em quatro anos, além de permitir que a $4^{a}$ série do Curso Normal fosse cursada por quem tivesse o certificado de conclusão do Colegial, mediante aprovação em exame das disciplinas pedagógicas. Esse novo rebaixamento da formação dos professores adquiriu repercussão nacional, pois essa reforma paulista deu bases para o que viria a ser a Lei de Diretrizes de Bases de 1971 (SOUZA, 2006; MARCílIO, 2005).

A Lei 5692/71 tornou caótica a formação específica do professor das séries iniciais. A redução das disciplinas pedagógicas e o empobrecimento dos conteúdos rebaixaram o nível de formação do professor das séries iniciais, gerando um grande descontentamento a nível nacional. Várias pesquisas, estudos e debates procuraram revitalizar o ensino normal ou equivalente, sem êxito (PIMENTA,1988; TANURY, 2000).

Devido à gravidade desta situação, a partir de 1982, a Secretaria da Educação do Estado de São Paulo realizou uma série de estudos para revitalizar a HEM. Vários encontros de educadores foram realizados por iniciativa do governo com o intuito de debater e procurar soluções para a questão. O Projeto Ipê, uma dessas iniciativas, vigorou no período de 1984 
a 1992, capacitava professores para alfabetização. As propostas curriculares, construídas entre 1986 e 1987, foram distribuídas na rede de ensino a partir de 1988, consolidando assim a reestruturação curricular do ensino de $1^{\circ}$ e $2^{\circ}$ graus iniciada em 1983 (SouzA, 2006):

As propostas curriculares não atingiam o professor que estava na ativa na rede porque foram construídas supondo um professor estudioso e um intelectual. Um professor-leitor que tivesse domínio no campo pedagógico em sua área de conhecimento (Souza, 2006).

\subsection{A Habilitação Específica para o Magistério Paulista da Nova República (de 1985 até os dias atuais)}

No governo Franco Montoro, ocorre nova reforma da HEM eliminando a compartimentalização e organizando o curso em um só bloco, para preparar o professor da pré-escola à $4^{a}$ série do $1^{0}$ grau, além de aumentar a instrumentação pedagógica. Mesmo assim os resultados não foram dos melhores.

Em 1987, foi criado no Estado de São Paulo o CEFAM - Centro de Formação e Aperfeiçoamento do Magistério, uma iniciativa apoiada pelo MEC que já tinha criado desde 1981 esses Centros em outros estados. Os CEFAMs tinham por objetivo reorganizar as Escolas Normais, para uma formação competente de profissionais do ensino primário e de pré-escola. A instalação do primeiro CEFAM no Estado de São Paulo deu-se em 1988.

$\mathrm{Na}$ tentativa de recuperar a especificidade da formação do professor das séries iniciais de escolaridade, nos CEFAMs, professores e alunos deveriam trabalhar em tempo integral, sendo estes últimos com bolsas de estudo com a finalidade de cumprir, já a partir do $2^{\circ}$ grau as 300 horas/ano de estágio supervisionado em pré-escolas e escolas públicas de $1^{\circ}$ grau (TANURY, 2000).

Infelizmente nem as HEM, nem os CEFAMs e tampouco os cursos de Pedagogia ofereceram uma formação de excelência para o professor das primeiras séries e da préescola do ensino fundamental (MARCílIO, 2005). Essa, talvez, seja uma das explicações básicas da atual situação do ensino brasileiro. A última tentativa do governo federal foi a criação do Curso Normal Superior através da Lei 9394/97, atual Lei de Diretrizes e Bases. Esse curso apenas elevou para o nível universitário a antiga Habilitação Específica para o Magistério, pois apresentou os mesmos problemas existentes nos cursos anteriores. Tanto que, num prazo de 10 anos após a sua criação, o curso entrou em fase de extinção e, atualmente, a formação de professores das séries iniciais é realizada novamente nos cursos de Pedagogia. 
A metodologia de Ensino de Ciências passou a ser parte da grade curricular dos cursos de HEM quando foi criado o CEFAM. Até então os professores formados em sua grande maioria tinham em sua formação apenas disciplinas relacionadas à didática e metodologia de alfabetização e de matemática. Ainda é comum, nos dias de hoje, encontrarmos universidades em que os cursos de licenciatura em Pedagogia possuem em sua grade cursos de Metodologia que, de forma generalizada, priorizam o ensino de alfabetização e matemática, um resquício da HEM. 


\section{Capítulo 4: Metodologia}

\section{As provas de Ophelia}

A grande figueira está morrendo. Para fazê-la viver, será preciso atirar três pedras mágicas na boca de um grande sapo que habita a sua raiz.

...com o giz, desenhe uma porta em qualquer lugar de seu quarto. Uma vez que a porta se abrir, vire a ampulheta e deixe-se guiar pelas fadas. Não coma e não beba nada durante a sua estadia. $E$ volte antes que caia o último grão de areia... 
Antes de enfrentar o Pale Man, Ophelia precisou encontrar o Grande Sapo que estava alojado na velha figueira. Ao encontrá-lo, deveria atirar-lhe três pedras mágicas que foram ofertadas anteriormente pelo Fauno para que pudesse extrair a chave dourada do estômago do batráquio. De posse da chave, após outro encontro com o Fauno, a menina recebe, agora, um giz mágico. Ao riscar uma porta na parede de seu quarto, vê com espanto que está no corredor do palácio do Pale Man e que, no final deste, há um salão esplêndido onde o monstro dorme sentado em frente a uma mesa posta com um riquíssimo banquete. Os olhos da fera descansam em um prato. Ophelia pega o prato com os olhos da fera e o fita com espanto e medo. Olha o afresco pintado na sala que mostra como o Pale Man matava e comia as crianças. Ao lado da fera também há uma pilha de sapatos de suas vítimas. Ophelia se aproxima, então, de um cofre e liberta as fadas da algibeira para que estas mostrem qual a fechadura certa para a abertura do cofre. Ao abrilo, vê que ali está um punhal, que guarda com todo cuidado em sua bolsa. Mas, ao passar novamente pelo banquete, não resiste e come dois grãos de uva, que são suficientes para despertar a fera. Apavoradas, as fadas tentam despistá-lo e duas delas morrem engolidas pelo monstro, restando apenas uma. Chocada com a cena que presencia, Ophelia corre e a fera a persegue, porém a porta mágica se tinha fechado. Risca novamente uma porta e consegue fugir da fera, com muito sacrifício.

Este foi um momento crucial para a pesquisadora: delimitar a metodologia de pesquisa para análise do curso de formação de professores.

\subsection{Pressupostos}

\subsubsection{A primeira pedra mágica: formação continuada de professores}

Segundo vários autores (GATTI,2000; DiAS \&LOPES,2003; MELLO,2000; FREITAS,2002), a formação continuada de professores no Brasil caracteriza-se, geralmente, por metodologias conteudistas, a exemplo de programas tais como o Parâmetros em Ação e a Rede de Formadores, patrocinados pelo MEC. Como o art. 87, § 4ํㅜㄹ da LDB nº 9.394/96 estabelece que "Até o fim da Década da Educação somente serão admitidos professores habilitados em nível superior ou formados por treinamento em serviço", muitos professores têm freqüentado cursos particulares de baixa qualidade em um precário processo de certificação que não conduz à qualificação do docente para a melhoria de sua prática. A formação em serviço tornou-se um para o setor privado uma fonte de lucro, conforme apontado anteriormente no Capítulo 3 , ao invés de se constituir em uma política pública de responsabilidade do Estado.

Os professores, assim como os demais profissionais, estão em processo contínuo de aprendizagem. Os cursos de formação continuada, quando preparados de forma a atender às necessidades dos educadores, favorecem a reflexão e conduzem à 
construção da autonomia profissional dos docentes (PAQUAY, 2001), além de minimizarem várias das deficiências decorrentes da estruturação e/ou da competência técnica dos cursos de formação inicial (KRASILCHIK \& CUNHA, 2007).

A discussão em grupo oferece espaço para a exposição de idéias, temores e para o embate de opiniões, contribuindo para a organização do pensamento. A criação de "ambientes" que favoreçam essa tempestade de idéias durante os encontros de formação continuada pode contribuir para a autonomia dos professores (GALIAZZI \& MORAES, 2002). Um curso de características construtivistas ou sócio-construtivistas pode, sob o ponto de vista da pesquisadora, contribuir para o estabelecimento de um ambiente que favoreça a interação entre os participantes como mostram TAYLOR \& COLL (2002). Esses autores sugerem que a formação continuada de professores primários os capacite para a proposição de modelos didáticos próprios, o que pode ser facilitado por cursos de formação de caráter construtivista.

Assim, a pesquisadora se propôs a investigar dois cursos de formação continuada, ministrados por ela própria, dos quais participaram professores das séries iniciais do Ensino Fundamental I, da Rede Pública Estadual de Ensino de São Paulo. O objetivo era o de verificar se, em cursos ministrados durante as horas de trabalho pedagógico coletivo, no ambiente da escola, havia possibilidade de que os professores-alunos incorporassem conceitos relativos à prática docente em Ciências, passando a empregálos durante as suas aulas.

Para tanto, a pesquisadora se propôs a realizar, além do curso de formação continuada, entrevistas pós-curso e recolha de textos e desenhos elaborados pelos alunos dos professores que participaram do evento. Através da análise do material coletado, pretende-se verificar se o curso em questão levou esses profissionais a refletirem quanto a sua prática em sala de aula, conduzindo-os a mudanças.

\subsubsection{A segunda pedra mágica: o paradigma do professor reflexivo}

De acordo com as idéias de Alarcão (2003), professor reflexivo é aquele profissional:

- que sabe questionar e gerenciar informações para transformar seu conhecimento em seu saber ou seja, possuidor de espírito crítico.

- que sabe atuar de forma inteligente, flexível, situada e reativa frente a situações incertas e imprevistas.

Embora haja dissidências entre ALARCÃO (2003) e PIMENTA (2006), concordamos com Pimenta quando ela nos alerta que: 
o conceito professor reflexivo não deve ser apenas uma moda dos governos neo-liberais, a medida em que o despe de sua potencial dimensão político-epistemológica, que se traduziria em medidas para a efetiva elevação do estatuto da profissionalidade docente e para melhoria das condições escolares, à medida que ocorreu em outros países...

É, por esse motivo que iniciamos esta Dissertação apontando uma perspectiva histórica do Magistério Paulista e realizamos contraposição com a formação dos professores em outros países, pois como ainda nos alerta PIMENTA (2006):

[...] que (outros países) não apenas transformaram as condições de formação dos professores, mas também significativamente suas condições de exercício profissional com jornada e salários compatíveis para um exercício crítico e reflexivo e de pesquisa, contribuindo para a elevação do estatuto da profissionalidade docente, esquecidas do governo brasileiro ...

Em princípio, os cursos de formação continuada deveriam favorecer a reflexão, conduzindo à construção da autonomia profissional dos docentes (PAQUAY, 2001). No Brasil, infelizmente, quase que imediatamente após sua inserção no mercado de trabalho, já há necessidade de que muitos professores aprofundem sua formação, inclusive no que se refere aos conteúdos de Ciências. De fato, devido a uma série de fatores estruturais, principalmente de caráter trabalhista e sócio-econômico, a maioria dos professores que se encontra, hoje, em exercício nas escolas estaduais e municipais no Estado de São Paulo não foi formada em instituições de alto padrão, com graves conseqüências para o ensino. Além disso, vários trabalhos ressaltam que até mesmo as instituições consideradas de alto padrão apresentam falhas em seus currículos, não sendo incomum a formação de professores despreparados em algum aspecto (KRASILCHIK \& CUNHA, 1999; PIMENTA, 2005).

Nesse contexto, os cursos de formação continuada, além de garantirem a atualização do professorado, têm contribuído para minimizar várias das deficiências decorrentes da estruturação e/ou da competência técnica dos cursos de formação inicial existentes no País.

\subsubsection{A terceira pedra mágica: o ensino de ciências para crianças}

No Brasil, conforme já discutido no Capítulo I, o ensino de Ciências para crianças das séries iniciais foi oficializado pela Lei 5692/71, mas o que realmente desencadeou este processo , foi uma das bases da consolidação do Ensino de Ciências no nosso país: a criação do Instituto Brasileiro de Educação, Ciência e Cultura (IBECC), em 1946, e da Fundação para o Desenvolvimento do Ensino de Ciências (FUNBEC), em 1967. Essas instituições tomaram a liderança no desenvolvimento de materiais didáticos na área de 
ensino de Ciências: o IBECC mantinha vários projetos, tais como: apoio a atividades escolares (feiras, museus e clubes de Ciências), pesquisas e treinamento de professores, a produção de kits de Ciências destinados a alunos do curso primário e secundário.

Com a promulgação da Lei 5692/71, que implantou o ensino profissionalizante, o Ministério da Educação instituiu o PREMEM - Projeto Nacional para a Melhoria do Ensino de Ciências, visando atender as novas exigências impostas pelas alterações curriculares. O programa, apoiado parcialmente pela USAID e pelo MEC, financiou três projetos: O Projeto de Ensino de Física, do Instituto de Física da USP, em 1972, o Projeto Nacional de Ensino de Química de $2^{\circ}$ grau, ligado ao CECINE (1972), e o Projeto de Ensino de Ciências (PEC), ligado ao CECIRS. Doze outros projetos foram ainda financiados até o final da década de 70 (NARDI, 2005). Esses projetos não chegaram a atingir amplamente os professores devido a uma multiciplicidade de fatores, dentre os quais a existência, em muitas escolas, de professores que não conseguiam utilizar o material produzido, inclusive pela falta de equipamentos requeridos pelos livros-texto (BRASIL,1997).

Para exemplificar a situação mencionada e por ter vivenciado parte deste período, em 1979, na terceira série do atual Ensino Fundamental, a pesquisadora recebeu o terceiro volume do livro "Ciências para o Curso Primário" de Ayrton Gonçalves da Silva e Equipe da FUNBEC e lembra perfeitamente que o livro todo era constituído de vários textos que terminavam em experimentos que envolviam fusão, condensação, magnetismo, eletricidade e outros. Embora houvesse esse cabedal de experimentos, a professora apenas lia o texto do livro e pedia para que o aluno respondesse o questionário... A parte experimental era para fazer em casa...se quisesse... pois os materiais requeridos nos experimentos não eram sofisticados.

O Programa ABC na Educação Científica - Mão na Massa teve seu início em 2001, ou por e tem por objetivo implementar o Ensino de Ciências Baseado em Investigação (ECBI) no Ensino Fundamental, principalmente no ciclo I (alunos de 6 a11 anos), a partir das abordagens La main à la pâte e Hands on, criadas respectivamente na França e Estados Unidos. Esse projeto estimula a formulação de questões sobre a realidade concreta, a elaboração de predições e o teste das hipóteses levantadas, ao mesmo tempo em que favorece um ambiente propício ao debate de idéias e ao desenvolvimento da capacidade de argumentação, através da confrontação de opiniões entre os educandos. Trata-se de um processo de formação continuada que se preocupa em favorecer um ambiente investigativo e um contato direto entre professores das redes de ensino, cientistas e especialistas em didática das ciências. (ABC, 2009): 
Atualmente, no Estado de São Paulo, participam educadores das redes municipais de ensino. Os professores da rede Estadual não participam do Programa. Apesar de ser um programa que está sendo difundido na América Latina, os educadores da Rede Estadual de Ensino o desconhecem. Quanto à metodologia, concordamos que as aulas devam ser dialógicas e que devam obedecer a uma seqüência organizada, mas discordamos quanto à formação continuada dos professores, pois os cursos de formação são para orientação de aulas já prontas e não da construção das mesmas pelos professores o que dificulta a construção de sua própria autonomia profissional, além de serem cursos à distância. A nosso ver, o curso deveria ser presencial devido às grandes dificuldades que boa parte dos professores do Ensino Fundamental traz consigo a respeito do pensar Ensino de Ciências nas séries Iniciais. Por outro lado, concordamos que o ensino de Ciências nas séries iniciais não está atrelado ao uso de equipamentos caros e nem a laboratórios sofisticados e a proposta da Mão na Massa envolve a utilização de materiais baratos, facilmente encontrados em casa.

\subsection{Caracterização do Estudo}

Esta investigação envolveu várias etapas, que estão sumariadas a seguir:

1. em outubro de 2004 , a investigadora elaborou um questionário com perguntas semi-estruturadas, aplicado a 50 professores das séries iniciais de uma escola da Rede Pública Estadual de São Paulo, situada na região central da Cidade de São Paulo; com o objetivo de verificar quais eram as concepções que os professores possuíam a respeito do ensino de Ciências para crianças.

2. foram ministrados dois Cursos de Formação Continuada voltados a professores do EF-I, - o primeiro dos quais, ministrado em 2005 e, o segundo, em 2006 - em que se utilizou um material instrucional construtivista para o ensino de Química: o PROQUIM ${ }^{1}$ (BELTRAN et al., 1987). A escolha do PROQUIM deveu-se a sua adequação à nossa proposta de trabalho, que pressupunha intensa manipulação de diferentes materiais pelos professores participantes, com o objetivo de permitir o desenvolvimento de habilidades técnico-motoras específicas e auto-confiança durante um curso permeado por diálogos em pequenos e grande grupos. Foi considerada a hipótese inicial de que os professores do EF-I não abordam conteúdos ou práticas referentes aos conteúdos de Ciências Naturais por sentirem-se inseguros quanto a esses tópicos (Bizzo, 1995);

\footnotetext{
${ }^{1}$ BELTRAN et al, 1987. PROQUIM - Projeto de Ensino de Química para o $2^{\circ}$ Grau.
} 
3. houve uma avaliação aplicada aos professores que participaram do segundo curso de formação continuada (E2), que culminou na proposta de realizarem projetos sobre o tema transformação para as classes em que ministravam aulas. O objetivo dessa atividade é verificar quais conceitos foram aprendidos pelo grupo.

4. foram conduzidas entrevistas com os professores após o curso com o objetivo de verificar o impacto do curso de formação continuada ministrado;

5. solicitou-se aos alunos dos professores entrevistados que desenhassem e escrevessem sobre as aulas de Ciências que haviam sido ministradas durante aquele ano letivo com o objetivo de verificar o impacto do curso sobre as rotinas pedagógicas docentes;

6. o material do curso, as entrevistas e as atividades das crianças foram submetidos a tratamento por análise do conteúdo (Bardin,2004) das entrevistas transcriadas ${ }^{2}$ (CAMPos, 1981). A Tabela 4.1 sumaria a organização do estudo realizado durante esta Dissertação.

Tabela 4.1: Técnicas/instrumentos para recolha e análise de dados.

\begin{tabular}{|c|c|c|c|c|}
\hline \multicolumn{5}{|c|}{ Técnicas/instrumentos para recolha e análise de dados } \\
\hline & Finalidade & Instrumento & Aplicação & Análise \\
\hline 1 & $\begin{array}{c}\text { Dimensionar o } \\
\text { problema }\end{array}$ & $\begin{array}{c}\text { Questionário semi- } \\
\text { estruturado }\end{array}$ & $\begin{array}{c}\text { Professores da } \\
\text { Escola E1 }\end{array}$ & Qualitativa \\
\hline 2 & $\begin{array}{c}\text { Favorecer a vivência } \\
\text { de práticas } \\
\text { construtivistas }\end{array}$ & $\begin{array}{c}\text { Curso de Formação } \\
\text { Continuada }\end{array}$ & $\begin{array}{l}\text { Professores das } \\
\text { Escolas E1 e E2 }\end{array}$ & \\
\hline 3 & $\begin{array}{l}\text { Verificar o impacto do } \\
\text { curso de formação } \\
\text { ministrado }\end{array}$ & $\begin{array}{c}\text { Entrevista com } \\
\text { professores }\end{array}$ & $\begin{array}{c}\text { Professores das } \\
\text { Escolas } 1 \text { e } 2\end{array}$ & $\begin{array}{c}\text { Qualitativa } \\
\text { Análise do Disrcurso }\end{array}$ \\
\hline 4 & $\begin{array}{c}\text { Verificar o impacto do } \\
\text { curso sobre as rotinas } \\
\text { pedagógicas } \\
\text { docentes }\end{array}$ & $\begin{array}{c}\text { Atividade de } \\
\text { desenho e escrita } \\
\text { com alunos }\end{array}$ & $\begin{array}{l}\text { Alunos dos } \\
\text { professores } \\
\text { entrevistados }\end{array}$ & $\begin{array}{c}\text { Qualitativa } \\
\text { Análise do Discurso }\end{array}$ \\
\hline
\end{tabular}

\footnotetext{
${ }^{2}$ Transcriação é um neologismo criado por Haroldo de Campos para denominar uma tradução que ultrapassa as fronteiras do significado e se propõe à fazer funcionar o próprio processo de significação original numa outra língua (PEREIRA, 2004), ou seja trata-se de uma "operação radical de tradução" (CAMPOS, 1981)
} 


\subsection{O giz mágico: o curso de formação continuada}

\subsubsection{Caracterização dos cursos ministrados}

A seleção do público-alvo da pesquisa desenvolvida durante esta Dissertação foi definida em função da experiência profissional da pesquisadora, professora titular de cargo efetivo das séries iniciais do EF da Rede Pública Estadual de Ensino há 20 anos.

Esta pesquisa foi realizada em duas escolas estaduais: uma (Escola 1; E1), localizada na região Central, tendo em seu quadro 80 professores e 1.200 alunos exclusivamente das séries iniciais do $\mathbf{E F}$, da qual 25 professores se voluntariaram para participar do curso. A Escola 2 (E2), situada na Zona Leste da Cidade de São Paulo, é composta de 100 professores, sendo 80 do EF-I e, os demais, do EF-II e Ensino Médio, dos quais 12 participaram do curso, sendo nove (09) nas séries iniciais do Ensino Fundamental e, os outros três (03), professores do Ensino Fundamental II e Médio. Este segundo grupo era constituído por uma professora de Língua Portuguesa, uma professora de Biologia e um professor de História que, mesmo não pertencendo ao público-alvo original, quiseram participar, pois o fato do curso abranger aulas práticas no laboratório despertou sua curiosidade.

Portanto, no total, o estudo abrangeu 37 professores das séries iniciais do EF. A média de tempo de serviço no magistério estadual dos professores participantes da investigação é de 13 anos, embora uma parcela significativa (67 e 92\%), E1 e E2 respectivamente não fosse efetiva (Tabela 4.2). São, em sua maioria (99\%), mulheres, de faixa etária compreendida entre 29 e 55 anos. Desses professores, 80\% possuem outra formação de nível superior (Pedagogia e/ou Licenciaturas) além da antiga Habilitação Específica para o Magistério.

Durante a realização dos cursos, ocorreram $50 \%$ de desistências, cujos motivos deveram-se a uma série de fatores conjunturais, tais como licenças-saúde e/ou prêmio ou individuais, que não foram investigados.

Tabela 4.2: Professores participantes da pesquisa.

\begin{tabular}{c|c}
\hline \hline \multicolumn{3}{c}{ Escolas } \\
\hline E1 & E2 \\
\hline \multicolumn{3}{c}{ Participantes } \\
\hline 25 & 12 \\
\hline \multicolumn{3}{|c}{ Efetivos } \\
\hline $02(8 \%)$ & $04(33 \%)$ \\
\hline \hline
\end{tabular}


As crianças que participaram tinham as suas idades variando entre 7 e 10 anos, em ambas escolas. Na E1, participaram 76 crianças e, na E2, 64 (Tabela 4.3). Dessas crianças, $90 \%$ encontravam-se no nível silábico-alfabético e alfabético da escrita, todas oriundas das classes populares.

Tabela 4.3: Crianças participantes da pesquisa

\begin{tabular}{c|c|c}
\hline \hline \multirow{2}{*}{ Escola } & Série & Crianças participantes \\
\hline \multirow{2}{*}{ E1 } & $4^{\mathrm{a}}$ & 38 \\
\cline { 2 - 3 } & $3^{\mathrm{a}}$ & 38 \\
\hline \multirow{2}{*}{ E2 } & $4^{\mathrm{a}}$ & 45 \\
\cline { 2 - 3 } & $1^{\mathrm{a}}$ & 19 \\
\hline Total & \multicolumn{2}{|c}{} \\
\hline \hline
\end{tabular}

\subsubsection{Os primeiros contatos}

Após a organização do curso, os Diretores das respectivas unidades escolares foram contatados para que fosse autorizada a divulgação da iniciativa para os professores da unidade escolar. Em ambas as escolas, tantos os diretores, quanto os professores, receberam bem a proposta e se propuseram a participar das atividades, além de terem sido autorizadas, explicitamente, a utilização do espaço da Escola e das informações coletadas em nossos estudos. Cabe ressaltar aqui que o curso foi intencionalmente ministrado em horário de $\mathrm{HTPC}^{3}$, por considerarmos esse horário como o espaço mais adequado para ações de formação continuada, pois assim, além de se evitar que os profissionais percam tempo em locomoção, por atividades no período de trabalho do professor, não há exclusão do profissional que exerça atividades em outras escolas.

\subsubsection{Objetivos específicos dos cursos}

A definição do eixo central do curso foi feita considerando-se, dentre os temas de Ciências Naturais sugeridos pelos PCN-Ciências para serem abordados durante primeiro ciclo, aqueles que enfocam

"o reconhecimento de processos e etapas da transformação de materiais em objetos e a realização de experimentos simples sobre os materiais e objetos do ambiente para a investigação de características e propriedades dos materiais e de algumas formas de energia (p.64).

${ }^{3}$ Conforme Portaria CENP $n^{0} 1 / 96$ que regulamenta o Horário de Trabalho Pedagógico Coletivo (HTPC) e a Lei Complementar $n^{\circ}$ 836/97 que dispõe sobre o Plano de Carreira do Magistério Estadual Paulista. Pedagogicamente, o HTPC é o momento privilegiado de encontro de todos os docentes de um ciclo de ensino, momento esse que deve ser de comunhão e troca de saberes. 
O conceito de transformação de materiais é central para a compreensão da linguagem usual da Química, sendo importante para o aprendizado de termos como substância e mistura. O domínio desses conceitos é fundamental para os professores, embora estejam ausentes do currículo de Ciências das séries iniciais, é difícil que eles possam ser autônomos na elaboração/seleção de recursos didáticos sobre o tema materiais sem a devida compreensão de tais termos. Em síntese, o objetivo geral do curso de formação, como proposto, é o de

- facilitar a apropriação de conteúdos e metodologias concernentes às Ciências Naturais e, mais especificamente, à Química, por professores das séries iniciais do Ensino Fundamental.

Mais especificamente, durante o curso o participante deverá adquirir os conceitos de transformação química, substância e mistura, apropriando-se da linguagem técnica para descrição dos sistemas observados.

No início do curso, foi realizada uma atividade sobre o tema água que culminava na construção de mapas conceituais coletivos e individuais com a finalidade de permitir que os professores explicitassem suas concepções sobre matéria e substância.

\subsubsection{PROQUIM}

O PROQUIM (Projeto de Química para o $2^{\circ}$ Grau) é um material instrucional organizado de modo a facilitar a ocorrência de aprendizagem significativa e a favorecer o desenvolvimento de habilidades de investigação. Está organizado de acordo com o princípio da diferenciação progressiva: os conteúdos são hierarquizados de modo a apresentar as idéias mais gerais e inclusivas para, em seguida, diferenciá-las progressivamente em relação a detalhes e especificidades (MAZON, 1989). Isto significa organizar o conteúdo através de temas centrais (AUSUBEL, 1980), isto é, de idéias amplas e relevantes no âmbito da disciplina, as quais devem, então, ser progressivamente diferenciadas em termos de detalhes e especificidades, com o intuito de facilitar que tais informações venham a ser significativamente aprendidas. Todas as atividades experimentais têm o objetivo de desenvolver habilidades motoras, além de habilidades tais como: observação, análise de dados e proposição de generalizações.

\subsubsection{Planejamento dos cursos}

Nos cursos ministrados, através de aulas práticas de laboratório, com posterior discussão em pequenos grupos e, finalmente, coletiva, os professores participantes tiveram oportunidade de ressignificar o conceito transformação, do senso comum às idéias aceitas na comunidade científica quanto à transformação de materiais. A Tabela 
4.4 apresenta o planejamento desses cursos.

Tabela 4.4: Planejamento.

\begin{tabular}{|c|c|}
\hline CONTEÚDO & ATIVIDADES \\
\hline $\begin{array}{c}\text { Água e substância química } \\
\text { água }^{a}\end{array}$ & $\begin{array}{c}\text { Construção de mapas conceituais sobre os } \\
\text { tema abordado }\end{array}$ \\
\hline \multirow{3}{*}{$\begin{array}{c}\text { Capítulo } 1^{\mathrm{b}} \\
\text { O que é uma reação química? }\end{array}$} & A química é velha? \\
\hline & Reconhecendo transformações \\
\hline & O que é uma reação química? \\
\hline \multirow{6}{*}{$\begin{array}{l}\text { Capítulo } 2^{\text {b }} \\
\text { Como se reconhece uma reação } \\
\text { química? }\end{array}$} & Ponto de ebulição \\
\hline & Ponto de fusão \\
\hline & Densidade \\
\hline & Solubilidade \\
\hline & Fatos e explicações \\
\hline & Outras aplicações das propriedades \\
\hline
\end{tabular}

a. construção de dois mapas conceituais: um sobre o tema água e, outro, abordando substância química água; b. capítulos do PROQUIM

\section{O primeiro curso (2005)}

Nesse curso participaram vinte e cinco (25) professores de uma Escola Estadual localizada na região central da cidade de São Paulo. Os encontros foram realizados durante os horários semanais de HTPC, que tinham a duração aproximada de uma hora. Devido a essa restrição de horário, o desenvolvimento das atividades correspondentes ao primeiro capítulo do PROQUIM levou quase seis meses. Esse evento foi importante, pois ajudou a ministrante a repensar o segundo curso e a organizar-se melhor quanto ao preparo e gerenciamento do tempo de cada atividade.

\section{O segundo curso (2006)}

O curso, de 21 horas, foi organizado em 14 encontros semanais de 90 minutos, nos horários destinados ao HTPC, de forma que fossem realizadas as atividades discriminadas na Tabela 4.4. Esse trabalho teve a duração de quatro meses e contou com a participação de doze (12) professores. Esse curso mais intensivo e sem a interrupção do professor Coordenador Pedagógico contribuiu que fosse melhor ministrado e consequentemente melhor aproveitado pelos participantes.

\subsection{Materiais coletados}

Para a coleta de dados durante as atividades de formação foram utilizados os 
seguintes procedimentos:

\section{Construção de mapas conceituais}

Mapas conceituais são diagramas que indicam relações entre conceitos. Embora, geralmente, estejam organizados de forma hierárquica, não devem ser confundidos com organogramas ou diagramas de fluxo, pois não implicam em seqüência, temporalidade, direcionamento, hierarquias organizacionais ou de poder. Mapas conceituais são apenas diagramas de significados, de relações significativas e de hierarquias conceituais (Moreira,1997).

Como sua técnica de confecção é muito simples e flexível, empregaram-se mapas conceituais como recurso facilitador da aprendizagem e meio de avaliação diagnóstica durante os cursos ministrados, por permitirem avaliar o domínio conceitual dos participantes de forma clara e objetiva, apresentando os conceitos que os indivíduos estão correlacionando de forma condensada. Em um mapa conceitual, quanto maior o número de inter-relações entre os conceitos, maior domínio conceitual a pessoa apresenta sobre determinado assunto.

\section{Questionário diagnóstico}

Preparou-se um questionário diagnóstico composto por dez (10) questões estruturadas e organizadas de acordo com os níveis de domínio cognitivo de Bloom (1973) com a finalidade de verificar a ressignificação do conceito de transformação (Anexo 7, p.32 a 34). Ele foi aplicado nos dois últimos encontros do curso na escola E2.

Os mapas conceituais e atividades dos primeiros capítulos do PROQUIM e o questionário diagnóstico foram organizados em pastas individuais, com as folhas de atividade devidamente datadas e organizadas em ordem cronológica.

\section{Entrevista pós-curso}

Após a conclusão dos cursos, os professores de ambas as escolas foram entrevistados com o objetivo de se perceber, através da análise das falas dos docentes a remanescência dos cursos.

Entrevista é a obtenção de informações de um entrevistado sobre determinado assunto ou problema. Uma entrevista pode ser padronizada ou estruturada (há um roteiro pré-estabelecido), despadronizada ou não-estruturada (não existe rigidez de roteiro), em que se podem explorar mais amplamente algumas questões (SILVA \& MENEZES, 2001) e, finalmente, semi-estruturada. As entrevistas semi-estruturadas caracterizam-se pela existência de um guia previamente preparado, como na estruturada, garantindo que os 
diversos participantes respondam as mesmas questões, porém não se exige uma ordem rígida das mesmas, como na padronizada. O desenvolvimento deste tipo de entrevista vai se adaptando ao entrevistado, mantendo um grau elevado de flexibilidade e exploração das questões (MINAYO, 1994). No nosso caso, foi escolhida a entrevista semi-estruturada por permitir maior liberdade de expressão do entrevistado, sem, porém, perda do foco da pesquisa.

As entrevistas, semi-estruturadas foram gravadas em áudio e transcritas empregandose o software gratuito Express Scribe ${ }^{4}$, que agiliza o processo de transcriação (CAMPOS, 1981) e categorização das entrevistas coletadas.

As entrevistas foram transcriadas respeitando-se a norma culta de escrita (CAMPOS, 1981), pois documentos escritos não são mais orais (VOGEL, 2008), mantendo-se a fidelidade ao conteúdo, mas retirando-se as marcas de linguagem e repetições comuns na oralidade. A diferença entre uma transcrição e uma transcriação é que, na transcrição, há preocupação com marcas de linguagem, que são mantidas na versão escrita da entrevista. Os erros de pronúncia também serão escritos conforme vão surgindo na gravação. Entendemos que, dessa forma, a atenção do leitor se fixará muito mais nas marcas de linguagem do que no conteúdo a ser abordado na pesquisa. Já na transcriação, omitem-se as marcas típicas da linguagem oral sem, no entanto, alterar o conteúdo da entrevista em questão.

As entrevistas com os professores da E1 e E2 foram direcionadas pelas perguntas mostradas no Quadro 4.1, sem a preocupação de manter uma rígida homogeneidade quanto a elas, pois a intenção da entrevista era a de deixar os entrevistados falarem o que realmente pensavam. Em alguns casos, a pergunta que seria feita já tinha sido respondida durante a resposta das anteriores (vide Quadro 4.1). Essas características são típicas de entrevistas semi-estruturadas.

1. Como é a classe que você pegou?

2. Como foi a escolha do livro didático de Ciências?

3. O quê você tem a dizer sobre o livro escolhido?

4. Você chegou a fazer alguma experiência? (do livro didático ou de outra fonte)

5. Como foram as aulas de Ciências? O quê você ensinou aos seus alunos neste ano, em Ciências?

6. Como os alunos reagiram frente às experiências?

7. Como os alunos se saíram na escrita do relatório? (Quando houve parte experimental na classe)

\footnotetext{
${ }^{4}$ adquirido no site: www.nch.com.au.
} 
8. Você imaginava que os alunos seriam capazes de fazer um relatório?

9. O quê você achou do curso que eu dei no ano passado?

10. O quê você mudaria naquele curso?

11. Como você gostaria que fosse o próximo curso?

12. Mudou a sua prática depois do curso?

Quadro 4.1: Perguntas utilizadas na entrevista

\section{O texto e o desenho infantil}

No mesmo período da realização das entrevistas com os professores, foi entregue aos alunos dos entrevistados uma folha de papel A4 que continha a seguinte comanda: "Faça um desenho sobre uma atividade ou experiência de ciências que o (a) professor (a) ensinou durante o ano e de que você tenha gostado. Em seguida, faça um pequeno texto relatando que você aprendeu com esta experiência ou atividade".

\subsection{O punhal obtido do Palácio de Pale Man: recortando os conteúdos sob a óptica de Bardin (Análise dos Dados)}

\subsection{1 $\quad \underline{\text { Coleta }}$}

Os dados recolhidos através das atividades do curso (mapas conceituais, questionários, entrevistas e atividade infantil) foram tratados utilizando-se o método de análise de conteúdo, que foi criado na primeira metade do século $X X$ com o objetivo de analisar comunicações. Trata-se de um conjunto de técnicas que utiliza procedimentos sistemáticos e objetivos de descrição do conteúdo das mensagens. Inicialmente, o material jornalístico passava por este tratamento. Posteriormente, passou a ser utilizado no âmbito da crítica literária, Psicologia, História, Sociologia e Ciências Políticas, dentre outros. Atualmente, seu domínio possível de aplicação estendeu-se a comunicações feitas por uma pessoa, entre duas pessoas, em grupos e de massa, seja o código linguístico escrito, oral, icônico ou outros códigos semióticos (BARDIN, 2004).

Após algumas leituras, as respostas às atividades do curso, ao questionário, às entrevistas e a atividade realizada foram segmentadas em elementos, posteriormente agrupados em conjuntos distintos através de um processo de diferenciação e reagrupamento para serem, então, categorizados segundo as categorias já préestabelecidas Conceito de Transformação, Formação Continuada e Formação Docente, conforme descrito a seguir.

\subsection{2 $\quad$ A análise do texto transcriado e da das questões do PROQUIM}


Após a transcriação das entrevistas, realizou-se a análise do conteúdo do material obtido, segundo três pólos cronológicos:

1) pré-análise;

2) exploração do material;

3) tratamento dos resultados, a inferência e a interpretação.

A técnica de análise de conteúdo a ser utilizada por nós será a análise categorial que trata do desmembramento do discurso em categorias em que os critérios de escolha orientam-se pela delimitação da investigação dos temas relacionados ao objeto de pesquisa, identificados nos discursos dos sujeitos pesquisados.

De acordo com BARDIN (2004), a categorização é uma operação de classificação por diferenciação de elementos que são parte de um conjunto que em seguida são reagrupados segundo o gênero (analogia). Deste modo, a análise de conteúdo categorial é alcançada por operações de desmembramento do texto em unidades, em categorias, segundo agrupamentos analógicos. Segundo a autora, a categorização tem por objetivo fornecer por condensação, uma representação simplificada dos dados brutos. As inferências finais são efetuadas a partir do material reconstruído. Através das relações entre as categorias, e de suas interpretações, é possível desenvolver explicações e afirmativas (proposições).

O critério de categorização adotado foi o semântico, por categorias temáticas, de acordo com seus significados, a partir das significações que a mensagem fornece. $O$ processo transcorreu da seguinte forma: fornecido o sistema de categorias, dividiram-se os elementos, à medida em que foram encontrados. Esse procedimento é chamado por BARDIN (2004) de "procedimento por caixas".

\subsubsection{Caracterização das dimensões, Categorias e Sub-Categorias} relativas ao curso de formação continuada e aos relatos dos professores $e$ alunos

As respostas às questões do PROQUIM elaboradas ao longo do curso de formação continuada foram analisadas para verificar se a realização das atividades e das discussões em grandes e pequenos grupos possibilitou que os professores ressignificassem o conceito de transformação. Para isso, as atividades desenvolvidas pelos professores foram analisadas em função do mostrado inicialmente na atividade individual de construção da Tabela 1.1 (Figura 4.1), proposta com o objetivo de fazer com que evocassem suas concepções acerca deste conceito. 


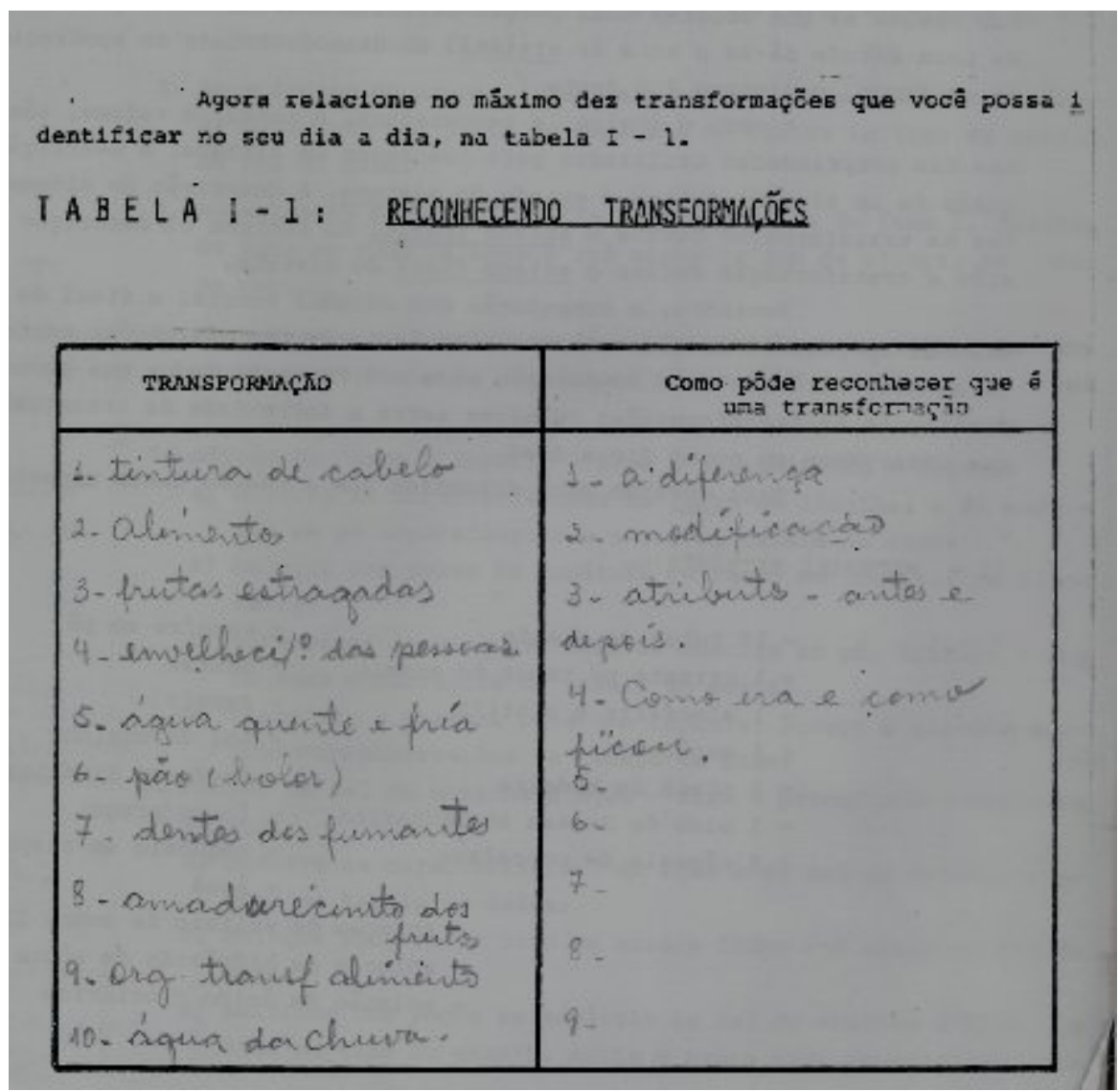

Figura 4.1 - Tabela I-1

As questões (vide Anexos) foram lidas uma a uma, para cada um dos participantes, e os resultados foram tabulados de acordo com o Quadro 4.2.

\begin{tabular}{|c|c|c|c|}
\hline \multicolumn{2}{|c|}{ Atividades/Capítulo } & \multirow{2}{*}{$\begin{array}{l}\text { "Houve Ressignificação" } \\
\text { Compara o estado inicial } \\
\text { com o estado final de um } \\
\text { sistema. }\end{array}$} & \multirow{2}{*}{$\begin{array}{l}\begin{array}{l}\text { Evocações de "Não houve } \\
\text { Ressignificação" }\end{array} \\
\text { Não compara }\end{array}$} \\
\hline \multirow{3}{*}{ 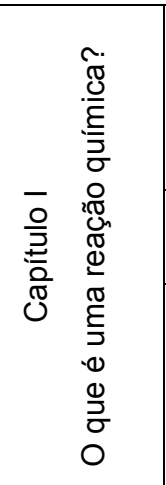 } & $\begin{array}{l}\text { IV-Tabela } \\
\text { de Dados }\end{array}$ & & \\
\hline & $\begin{array}{l}\text { V- Análise de } \\
\text { dados }\end{array}$ & $\begin{array}{l}\text { Identifica as evidências de } \\
\text { formação de novos materiais }\end{array}$ & Não identifica \\
\hline & VII- Exercícios & $\begin{array}{l}\text { Identifica estado final e inicial } \\
\text { de um sistema. } \\
\text { Encontra evidências de uma } \\
\text { reação química ou a ocorrência } \\
\text { de um fenômeno físico. }\end{array}$ & Não explica \\
\hline \multirow{2}{*}{ 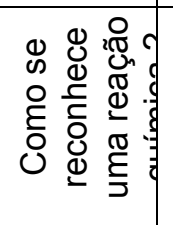 } & \multirow[b]{2}{*}{ Parte A } & $\begin{array}{l}\text { Justifica a diferença de massa } \\
\text { em frascos de mesmo volume. }\end{array}$ & Não justifica \\
\hline & & $\begin{array}{l}\text { Percebe que a densidade de } \\
\text { uma substância não varia, } \\
\text { enquanto que de uma mistura } \\
\text { varia. }\end{array}$ & Não percebe \\
\hline
\end{tabular}




\begin{tabular}{|c|c|l|l|}
\hline Parte B & $\begin{array}{l}\text { Consegue justificar porque um } \\
\text { navio não afunda, sabendo que } \\
\text { a densidade do ferro é maior } \\
\text { que da água. }\end{array}$ & Não justifica \\
\hline
\end{tabular}

Quadro 4.2 -Evocações do Capítulo I em “Houve Ressignificação” e "Não houve

\section{Ressignificação"}

No caso das questões propostas no item VII após a leitura da respostas dadas, notamos que no item "a" o professor em questão não identificou o sistema em estudo, mas nos itens "b", "c" e "d" identificou o estado inicial e final do sistema e a evidência de uma reação química. No caso da questão 2 , não consegue explicar se a transformação é química ou física e na questão 3 consegue identificar que se trata de uma transformação física. Neste caso, como o professor resolveu $80 \%$ das questões, o classificaremos dentro da categoria "houve ressignificação". A seguir os exercícios do item VII, mostrados na Figura 4.2.

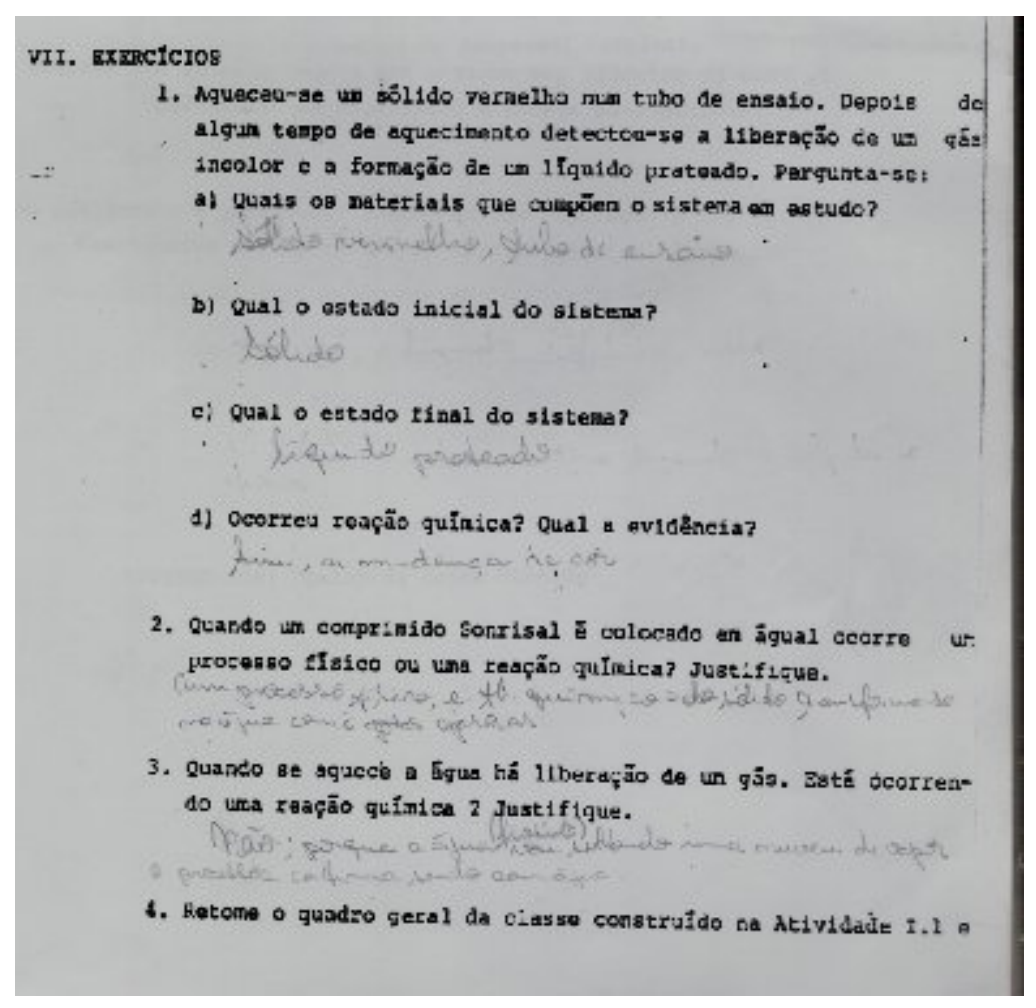

Figura 4.2- Item VII - Exercícios

Procedimento semelhante foi utilizado para analisar as questões do Capítulo II, "Como se reconhece uma reação química?

Os textos das entrevistas dos professores e dos alunos foram analisados considerando a primeira dimensão: "curso de formação continuada". Essa dimensão remete ao curso ministrado em ambas as escolas e permite avaliar o impacto desses 
cursos sobre os docentes entrevistados. Da análise do texto das transcriações das entrevistas e da leitura das atividades dos alunos, segundo essa dimensão, emergem duas Categorias, cada uma delas subdividida em sub-Categorias, como mostrado na Figura 4.3.

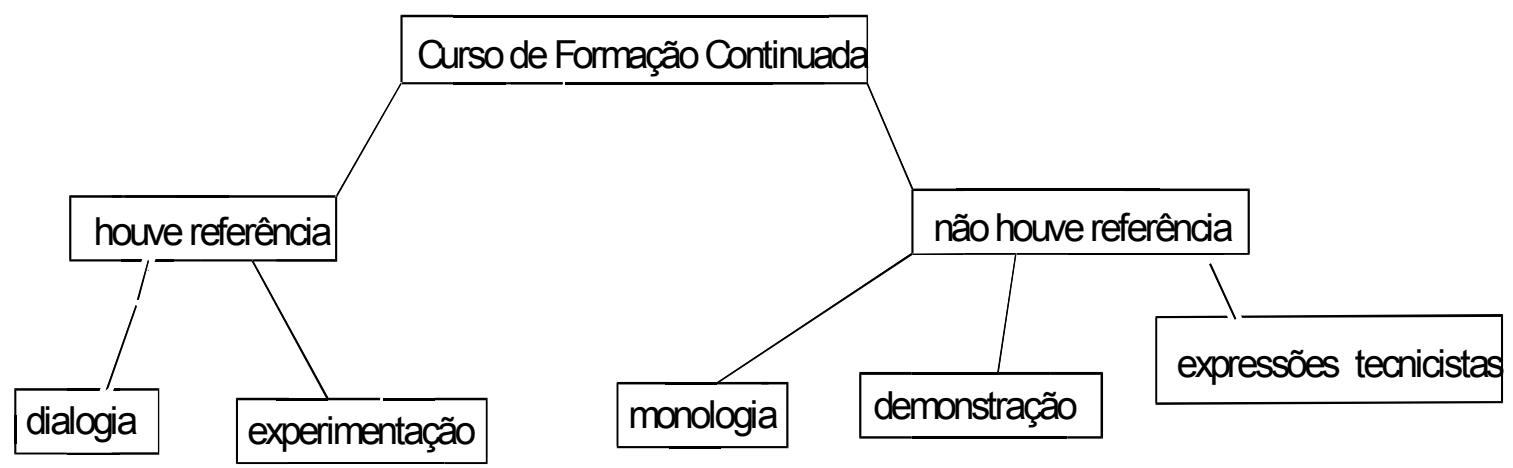

Figura 4. 3- Categorias e sub-Categorias da dimensão Curso de Formação Continuada.

Nas entrevistas classificadas na Categoria 2 (não houve influência) não se percebem reflexos do curso de formação continuada nas práticas didáticas dos professores, enquanto, no caso da Categoria 1 (houve influência), aparecem explicitamente evocações que remetem às atividades desenvolvidas ou às metodologias empregadas durante o curso. Tais evocações estão elencadas na Tabela 4.5:

Tabela 4.5: Exemplos de evocações de professores e alunos para a Categoria houve influência.

\begin{tabular}{|c|c|c|}
\hline \multirow{4}{*}{ 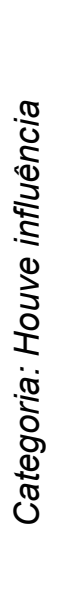 } & Evocações & Exemplos \\
\hline & Mapas conceituais & $\begin{array}{l}\text { Durante suas aulas, orientaram os alunos na construção } \\
\text { de mapas conceituais. }\end{array}$ \\
\hline & Escrita de relatório & $\begin{array}{l}\text { Discussões com o coletivo da turma para orientação da } \\
\text { escrita. Escrita espontânea. }\end{array}$ \\
\hline & $\begin{array}{l}\text { Referências ao conceito } \\
\text { água nas aulas }\end{array}$ & $\begin{array}{l}\text { Conceito água abordado segundo várias perspectivas, tais } \\
\text { como: ciclo da água na natureza, cuidados referentes à } \\
\text { higiene/saúde e economia de água, lençol freático, os } \\
\text { caminhos da água na natureza. }\end{array}$ \\
\hline
\end{tabular}

Da Categoria 1, emergiram três outras Categorias, a dialogia, a experimentação e o livro didático que estão elencadas com os seus respectivos exemplos na Tabela 4.6. 
Tabela 4.6: Exemplo de evocações de professores e alunos para sub-Categorias da Categoria: houve influência

\begin{tabular}{l|c|l}
\hline \hline Sub-Categoria s & Evocações & \multicolumn{1}{c}{ Exemplos } \\
\hline \multirow{2}{*}{ Dialogia } & Dialogia & $\begin{array}{l}\text { Narração de interação entre professor e alunos e entre } \\
\text { alunos em pequenos e grandes grupos. Apropriação da } \\
\text { fala de uns dos outros. }\end{array}$ \\
\cline { 2 - 4 } & Termos & $\begin{array}{l}\text { "Eu aprendi" ou "Nós aprendemos" ou ainda "A gente } \\
\text { aprendeu" antes de ações referentes à experimentação } \\
\text { ou antes de conclusão sobre o experimento. Escrita } \\
\text { espontânea do texto, com vocabulário próprio. }\end{array}$ \\
\hline Experimentação & Aceitação & $\begin{array}{l}\text { Realização de experimentos e manipulação do torso } \\
\text { humano. }\end{array}$ \\
\hline \hline
\end{tabular}

Da Categoria 2 (não houve influência) emergiram três sub-Categorias conforme explicitado na Tabela 4.7: expressões tecnicistas ${ }^{5}$, à monologia que aqui denominamos termos que abrangem situações em que não há um diálogo em sala de aula, o professor explica a teoria ditada ou exposta na lousa e não se preocupa efetivamente se o aluno está compreendendo ou não, a demonstração que se refere a atividades experimentais demonstradas pelo professor e ao livro didático que são relatos de rejeição ao livro didático que contenham experimentos e questões reflexivas.

Tabela 4.7: Exemplo de evocações de professores e alunos para a Categoria Não Houve Influência.

\begin{tabular}{|c|c|c|c|}
\hline & Sub Categoria s & Evocações & Exemplos \\
\hline 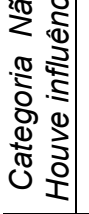 & $\begin{array}{l}\text { Expressões } \\
\text { Tecnicistas }\end{array}$ & $\begin{array}{l}\text { livro didático } \\
\text { à prontidão para } \\
\text { aprendizagem }{ }^{6} ; \\
\text { a aulas prontas, } \\
\text { cópia } \\
\text { reprodução }\end{array}$ & $\begin{array}{l}\text { Livro com texto e perguntas diretas; } \\
\text { o aluno é "muito novinho" para fazer experimentos } \\
\text { previamente preparadas em apostilas ou folhas individuais } \\
\text { de texto da lousa ou do livro } \\
\text { o professor elabora uma aula com textos de vários livros } \\
\text { didáticos }\end{array}$ \\
\hline
\end{tabular}

${ }^{5}$ refere-se a modelos didáticos não-dialógicos e ao tecnicismo, que teve seu auge nas décadas de 70 e perdurou até meados da década de 80, do século XX (KUENZER,1999).

${ }^{6}$ O aluno precisa estar com suas faculdades mentais "amadurecidas" para aprender determinado conceito. Essa idéia sobre a cognição era apresentada na disciplina Psicologia da Aprendizagem das HEM e muitos professores das séries iniciais ainda defendem essa proposta. 


\begin{tabular}{|c|c|c|}
\hline $\begin{array}{l}\text { Monologia } \\
\text { (monólogos) }\end{array}$ & $\begin{array}{l}\text { aulas expositivas } \\
\text { ausência de diálogo } \\
\text { atividades individuais, } \\
\text { o foco no ensino, } \\
\text { termos } \\
\text { pronome } \\
\text { textos. }\end{array}$ & $\begin{array}{l}\text { Enfase em teoria } \\
\text { Entre professor-alunos e alunos-alunos para discutir a aula } \\
\text { Os alunos não realizam atividades em grupo para discussão } \\
\text { o professor é sujeito da aprendizagem dos alunos } \\
\text { "o professor ensinou","eu aprendi" atrelado a um texto } \\
\text { teórico } \\
\text { em primeira pessoa do singular (eu) antecedendo os verbos } \\
\text { escritos de forma impessoal, semelhantes ao do livro } \\
\text { didático caracterizando uma escrita não espontânea }\end{array}$ \\
\hline Demonstração & relatos & $\begin{array}{l}\text { De atividades experimentais e manipulação de materiais } \\
\text { feitas pelo professor }\end{array}$ \\
\hline Livro Didático & relatos & $\begin{array}{l}\text { Rejeição ao livro didático com experimentos e questões } \\
\text { reflexivas }\end{array}$ \\
\hline
\end{tabular}

Os textos das entrevistas dos professores também foram analisados considerando a Dimensão "formação docente". Esta Dimensão remete à formação inicial e continuada recebida pelos professores de ambas as escolas, antes do curso de formação continuada que deu origem a esta Dissertação e permite analisar a formação profissional dos participantes. Desta Dimensão, surgiram duas Categorias referentes à formação: a Categoria 3- formação inicial, e a Categoria 4, formação continuada, conforme ilustrado na Figura 4.4:

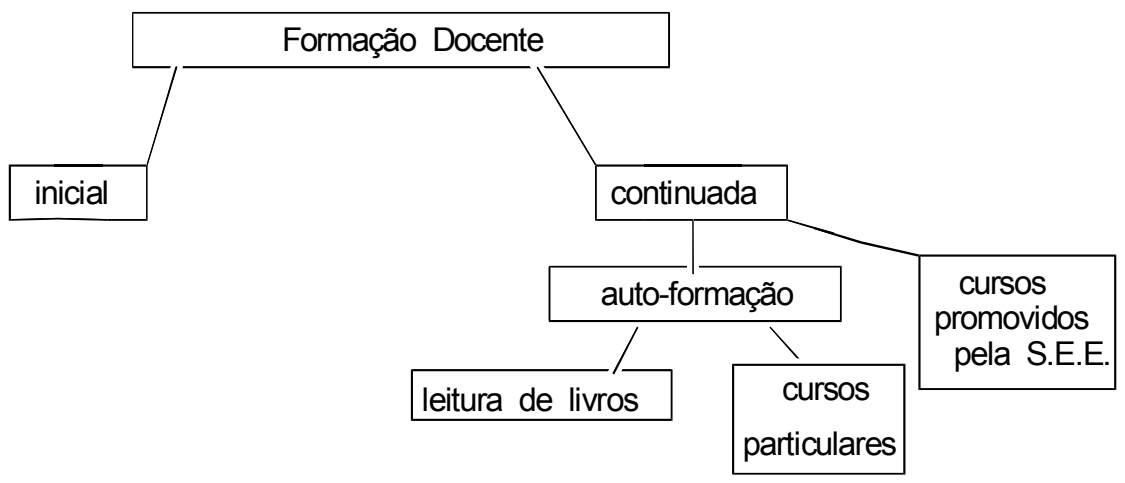

Figura 4.4: Categorias e Sub-Categorias da Dimensão Formação Docente

A Categoria 3, formação inicial, compreende a primeira formação que o professor recebeu para tornar-se um profissional do magistério. Nesta Categoria, há evocações sobre a formação generalista que o profissional recebeu seja na H.E.M, seja no curso de Pedagogia.

A Categoria 4, formação continuada, refere-se às formações continuadas que o profissional recebeu antes do nosso curso. Essa Categoria encontra-se subdividida em duas outras sub-categorias: auto-formação, que se refere a leituras e cursos que o profissional fez por conta própria e cursos de formação continuada promovidos através da Secretaria de Estado da Educação (S.E.E.) e de suas respectivas Diretorias de Ensino. Enquadram-se nessa Dimensão e Categorias uma série de evocações que estão apresentadas na apresentadas no Quadro 4.3. 


\begin{tabular}{|c|c|}
\hline & f̧ões \\
\hline 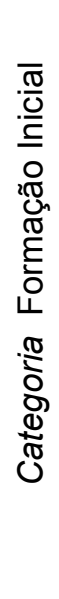 & $\begin{array}{l}\text { Polivalente } \\
\text { não aprofundada } \\
\text { menção a metodologia do ensino de Ciências } \\
\text { ausência de metodologia e didática de Ciências } \\
\text { sente falta de metodologia e didática de Ciências } \\
\text { falta de preparo para ensinar } \\
\text { foco na alfabetização e na matemática } \\
\text { aulas decorativas } \\
\text { ponto e questionário } \\
\text { aprendeu teoria } \\
\text { conteúdo jogado } \\
\text { falta de segurança para trabalhar Ciências } \\
\text { medo de acontecer algo durante a prática experimental. } \\
\text { durante o curso de Pedagogia teve práticas experimentais para serem reproduzidas em } \\
\text { sala de aula }\end{array}$ \\
\hline
\end{tabular}

\section{Quadro 4.3: Evocações da Formação Inicial Docente}

O Quadro 4.3, como já foi dito anteriormente, refere-se à formação continuada do professor, como a auto formação que pode se dar através da leitura e pesquisa de livros, jornais e revistas e por cursos de formação continuada freqüentados por iniciativa própria, ou, então cursos promovidos pela S.E.E. como o Letra e Vida que visa alfabetização e letramento, o Procel sobre economia de energia e cursos de formação continuada em ciências em geral.

\begin{tabular}{|c|c|c|}
\hline \multirow{3}{*}{ 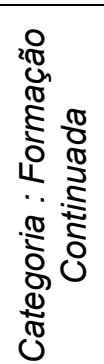 } & Sub Categoria s & Evocações \\
\hline & Auto formação & $\begin{array}{l}\text { Leitura e pesquisa de livros } \\
\text { Leitura e pesquisa de jornais } \\
\text { Leitura e pesquisa de revistas } \\
\text { Cursos freqüentados por iniciativa própria }\end{array}$ \\
\hline & $\begin{array}{l}\text { Cursos } \\
\text { promovidos pela } \\
\text { S.E.E. }\end{array}$ & $\begin{array}{l}\text { Letra e Vida } \\
\text { Procel } \\
\text { Ciências: tema ar }\end{array}$ \\
\hline
\end{tabular}

Quadro 4.4: Evocações da Formação Continuada anteriores ao curso ministrado

A seguir apresentaremos um trecho de uma entrevista com professor e como a análise foi feita. Exemplificaremos aqui a categoria "Houve Influência":

\section{Categoria "Houve Influência" - referência à escrita de relatório}

SUBCATEGORIA DIALOGIA - REFERÊNCIA À DISCUSSÃO EM GRUPO

Entrevistador: Certo .E qual foi a reação dos alunos frente a essas experiências?

Professor A: Olha o que deu para perceber é que o interesse é bem maior quando você trabalha com experiência. Essa do pão foi um pouco mais rápida, mas essa da carne que levou um tempo então a gente descia,ia lá fazia anotações, DISCUTIA,ELES OBSERVAVAM, PEGAVAM E ASSIM O INTERESSE DE IR TODO DIA LÁ PARA VER O QUE ESTAVA ACONTECENDO. UMA PARTICIPAÇÃO BEM MAIOR ASSIM, PARECE QUE PARA ELES É MUITO MAIS INTERESSANTE QUANDO É TRABALHADO EXPERIÊNCIA.

Entrevistador: No que se refere à parte escrita, como que eles foram? Em relação a escrever relatório?

Professor A: Então, o interessante é que eles tiveram facilidade em escrever assim, todo o 
processo, não é ? Fizeram o desenho, escreveram todo o processo de como se deu desde aqui, o começo na sala e todo o desenvolvimento da experiência.

Quadro 4.5- Exemplo de como foram extraídos as categorias e subcategorias

O material escrito dos alunos foi passou pelo mesmo processo de análise para posteriormente comparar os dados obtidos dos professores e das crianças. Como exemplo, ilustraremos na Figura 4.8 ilustra como foi feita a análise.

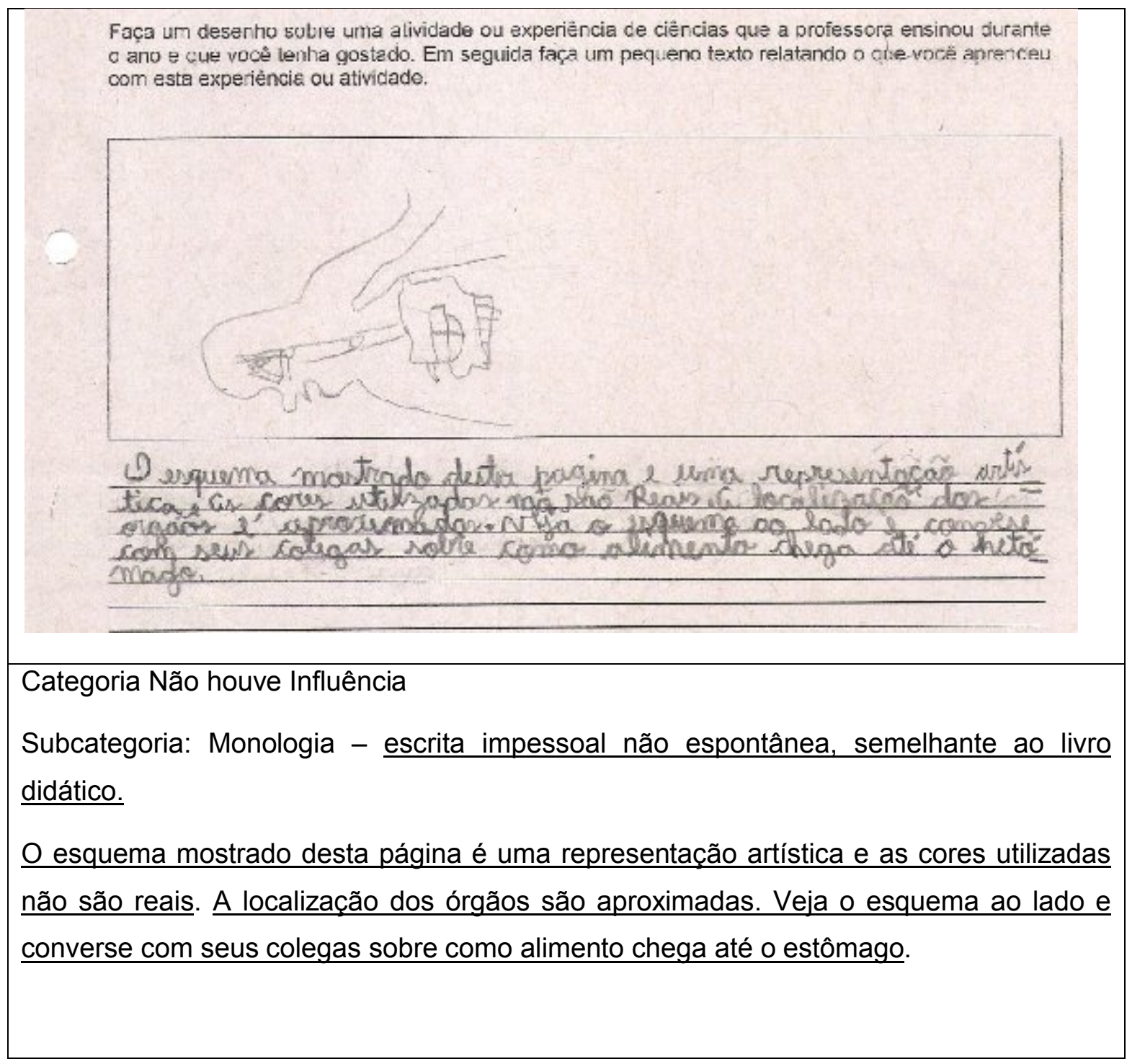

Figura 4.5:- Exemplo de atividade de aluno pertencente à categoria "Não Houve Influência" 
Capítulo 5: Resultados e Discussão

A última prova de Ophelia 
De posse do punhal, Ophelia se encontrou com o Fauno e este a felicitou por ter passado por mais uma prova. Ele a orientou que deveria derramar o sangue de um inocente. $\mathrm{Na}$ mesma noite, o quartel é invadido pelos camponeses, Ophelia se aproveita da confusão para pegar seu irmãozinho no quarto do General Vidal e fugir. Antes disso, ela, coloca sedativo no copo de uísque que estava sobre a escrivaninha do general. O general Vidal mesmo ferido e dopado a persegue até a entrada do labirinto. Ophelia se encontra com o Fauno e este toma o punhal para fazer uma punção no irmão para que seja derramado o seu sangue. Ophelia se recusa terminantemente e o Fauno apenas the responde "como quiseres, princesa". Nesse mesmo tempo, o General toma a criança e atira em Ophelia, e esta agoniza no portal do labirinto...

O título deste Capítulo, um tanto quanto dramático, representa os resultados depreendidos da análise dos escritos dos cursos de formação continuada, das entrevistas com os professores e do material coletado das crianças. O General Vidal que persegue Ophelia representa o Regime Militar que contribuiu para estagnar de vez a grade curricular da HEM como foi discutido no capitulo 03. Ophelia representa, na verdade, todas os professores das séries iniciais que foram formados durante a década de 70 e 80 dos anos 1900. Após a análise dos resultados a respeito do curso de formação continuada, foram feitas entrevistas com seis professores que continuaram a trabalhar nas escolas em que foi feito o trabalho. O objetivo dessas entrevistas era o de verificar se esses dois professores foram influenciados pelo curso a ponto de modificar sua prática docente. Traçando o paralelo com o filme de Del Toro, o subcapítulo dedicado a esse caso foi denominado "quando Ophelia regressa ao Reino Subterrâneo", uma alusão aos professores que superaram de certa forma a sua formação inicial marcada pelo tecnicismo e que passaram a ministrar aulas dialógicas. No caso dos professores que não foram influenciados pelo curso, o subcapítulo recebeu o nome "quando Ophelia morre nas mãos do General", uma alusão aos professores que continuaram fortemente vinculados à sua formação inicial.

\subsection{Análise das atividades iniciais do curso: caracterização dos professores}

\subsubsection{Mapas conceituais}

Esta atividade foi desenvolvida em ambas as escolas, abrangendo um total de 27 professores, com o objetivo de verificar se a externação do conceito água era influenciada pelo contexto da pergunta. A hipótese subjacente à proposição desta atividade era a de que seria possível inferir a concepção dos professores sobre aspectos relativos às Ciências Naturais pela análise dos mapas conceituais propostos. Foram obtidos 5 mapas (exemplos 
nas Figuras 5.1 a 5.3), elaborados por grupos de três a quatro professores, que revelaram que o conceito água remetia a evocações as mais diversas, relacionadas a sensações, necessidades básicas, fenômenos naturais, cursos e reservatórios, higiene, vida, classificações quanto à qualidade e à sobrevivência e terminologias utilizadas na linguagem científica.

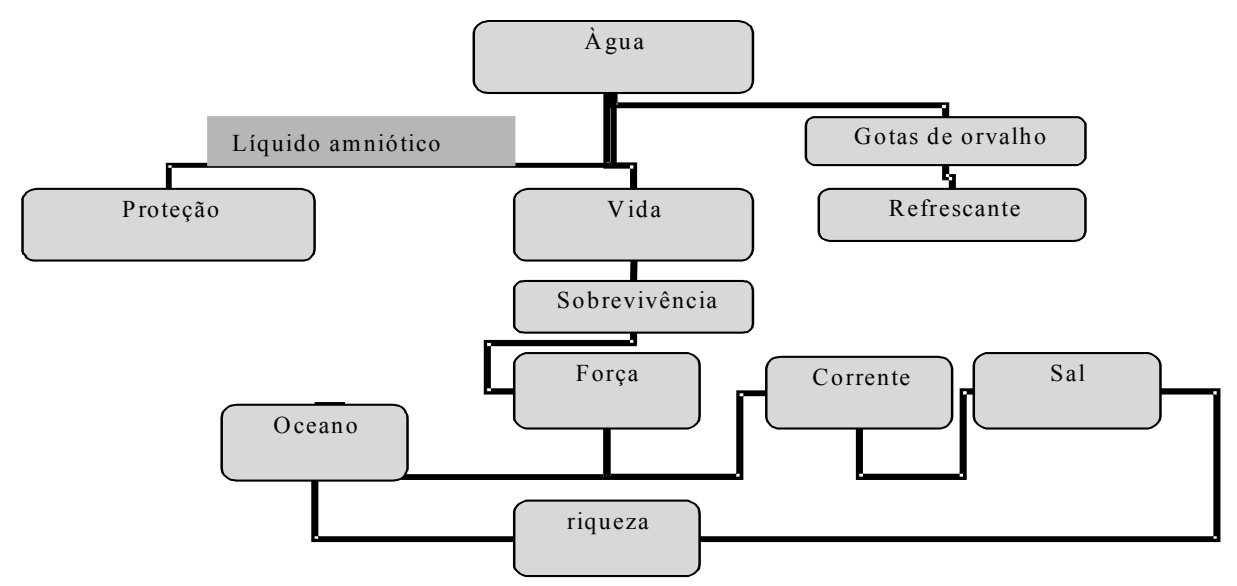

Figura 5.1: Mapa conceitual de "água“, para E1.

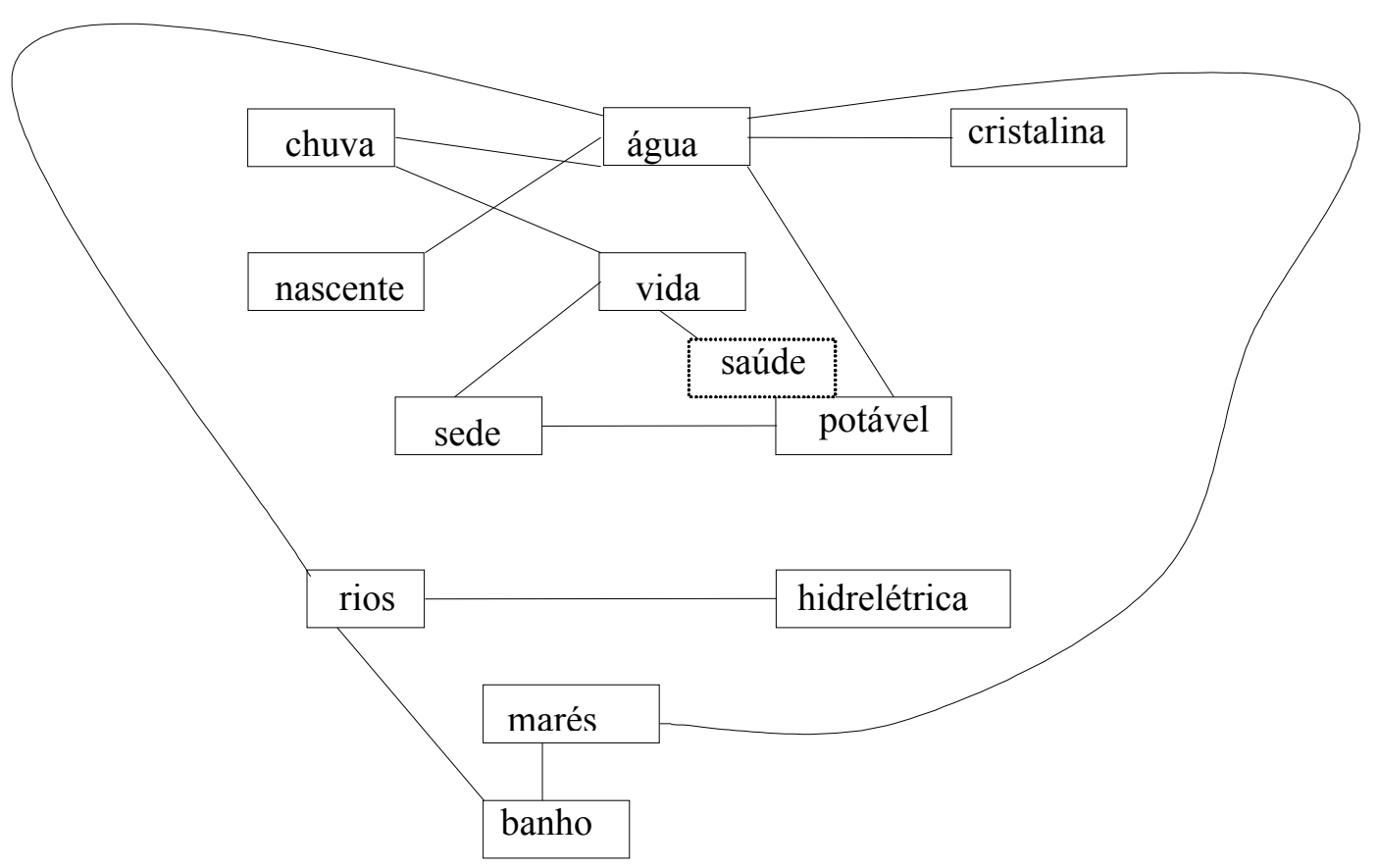

Figura 5.2: Mapa conceitual de "água“, para E2 


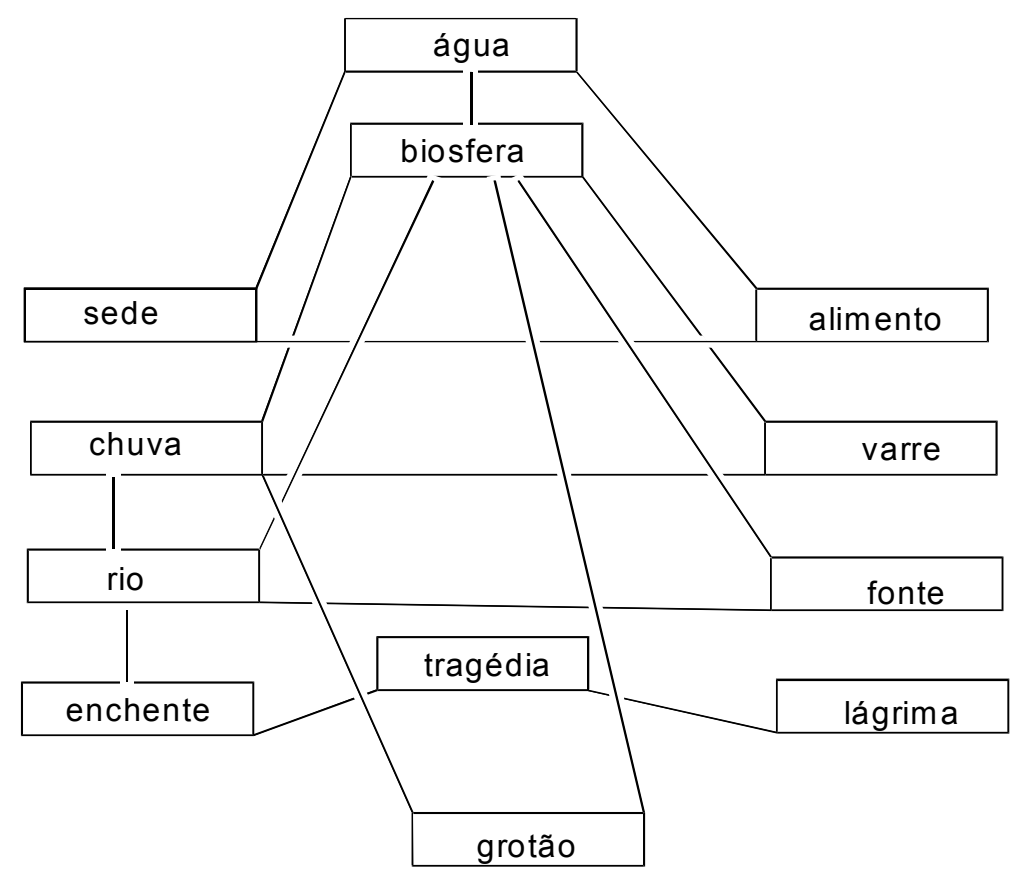

Figura 5.3: Mapa conceitual de "água“, para E2

Os mapas sobre o conceito "substância química água", apresentados nas Figuras 5.4 a 5.6, foram elaborados individualmente no segundo encontro, que se iniciou com a leitura do texto "Como construir mapas conceituais" (MOREIRA, 1997). Os professores entregaram 10 atividades, das quais apenas 08 foram consideradas efetivamente como mapas conceituais, pois as outras sequer havia inter-relação de conceitos.

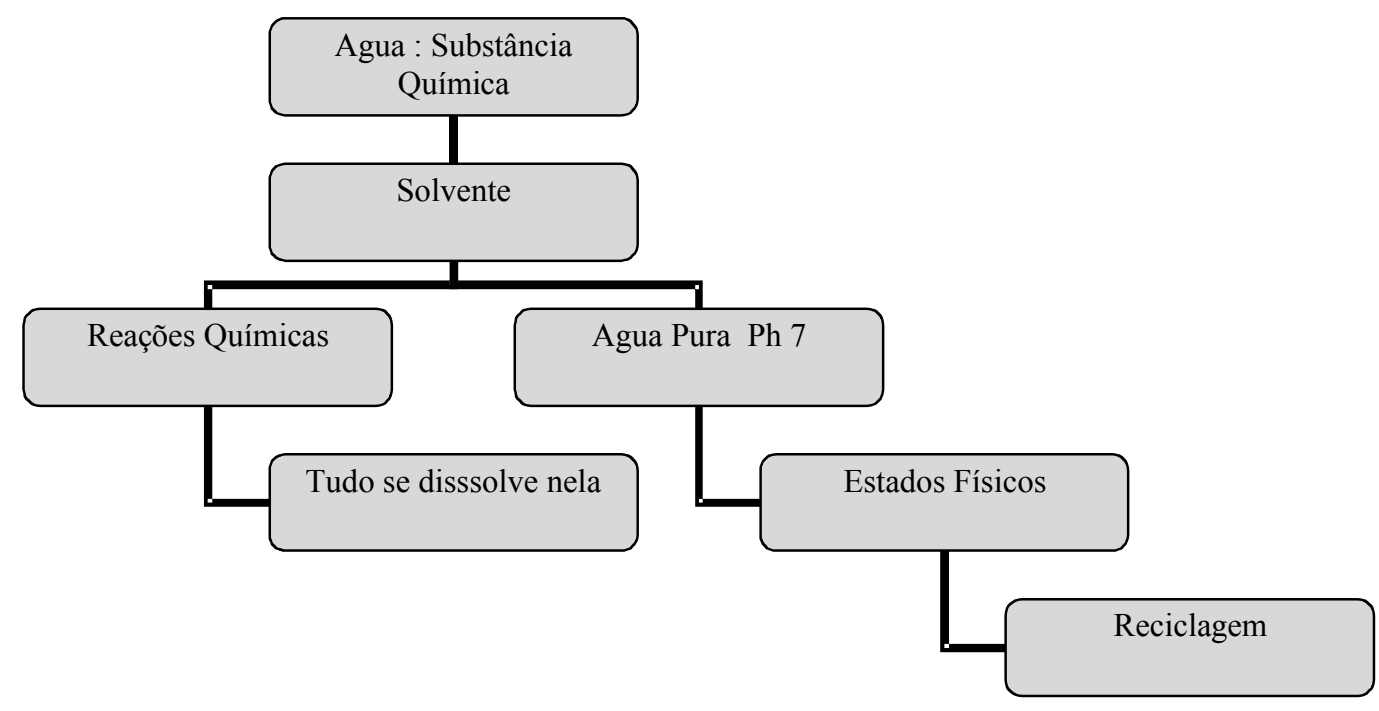

Figura 5.4: Mapa conceitual de "substância química água“, para E1 


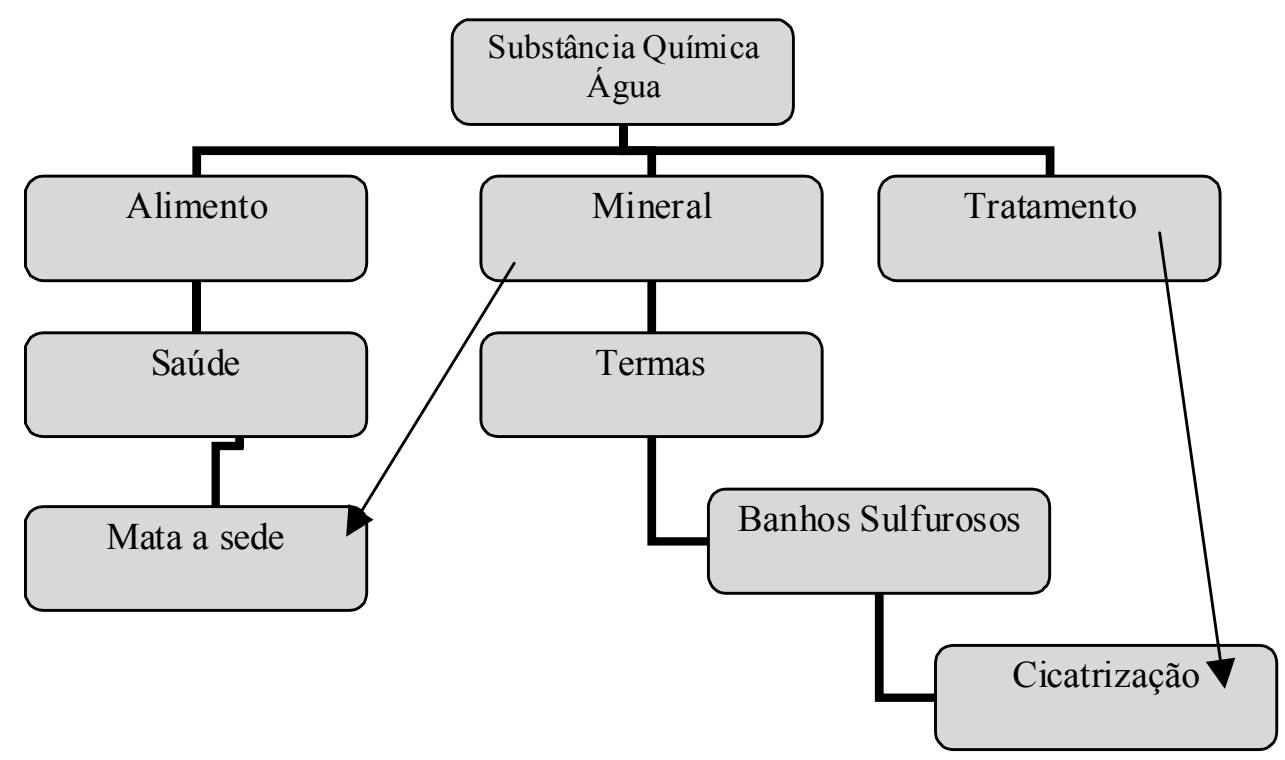

Figura 5.5: Mapa conceitual de "substância química água", para E1.
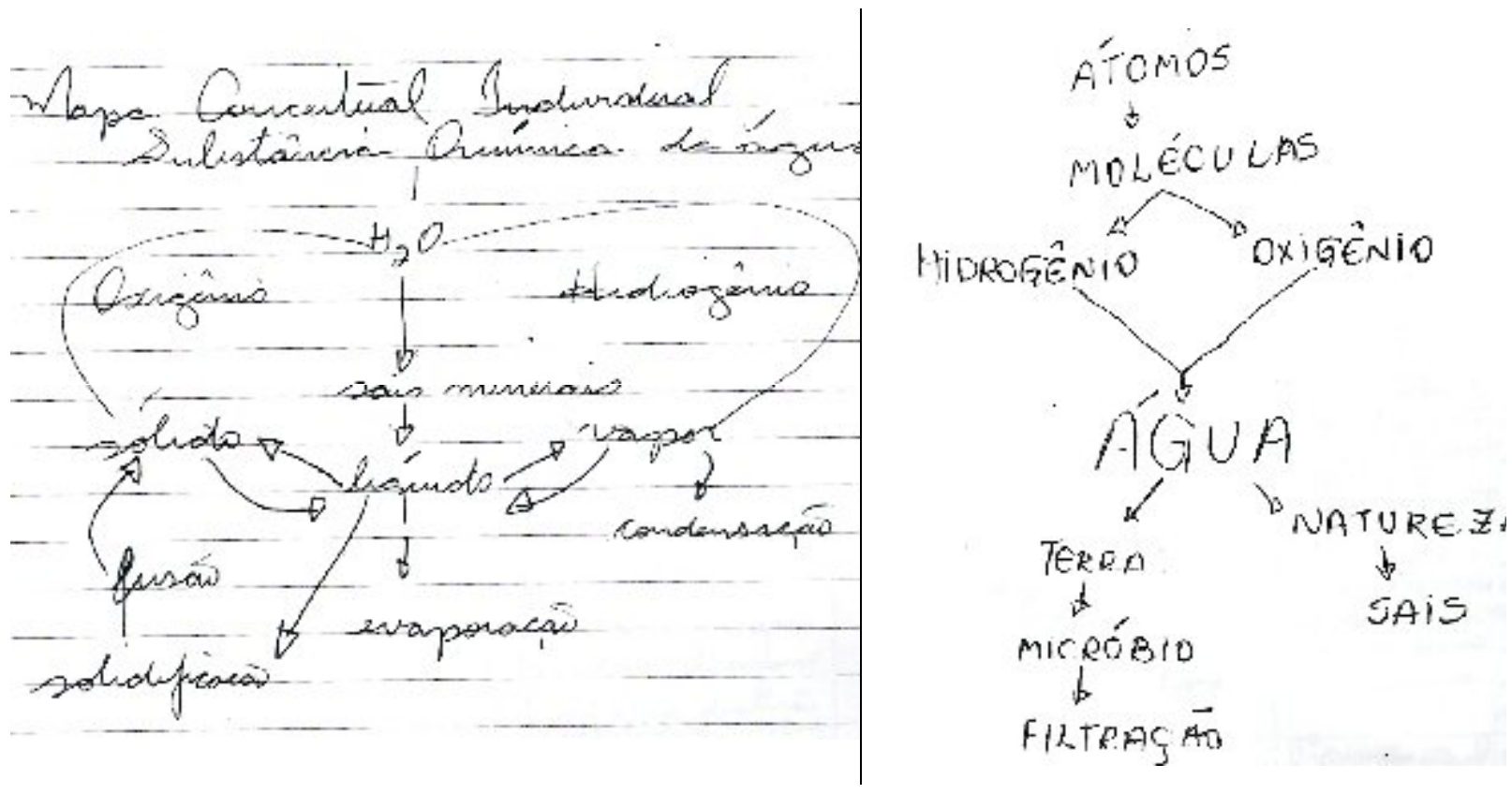

Figura 5.6: Mapa conceitual de "substância química água“, para E2.

A análise dos mapas mostrados nas Figuras 5.4 a 5.6 mostra que houve mudanças significativas quando o conceito proposto foi "substância química água". Assim, os mapas apresentaram restrição de conceitos e o desaparecimento completo de evocações relacionadas às sensações. Em seu lugar, intensificaram-se as referências a termos 
científicos e a doenças transmitidas através da água (VOGEL et al, 2005). Por outro lado, os mapas referentes a "substância química água" apresentam uma média de inter-relações em torno de 1,5, enquanto, nos mapas conceituais referentes à "água", esse número era de 1,1, o que pode ser interpretado como um indício de apreensão gradativa da técnica de construção de tais mapas (TAVARES et al, 2005).

Estes resultados sugerem que o conceito água quando acompanhado do termo "substância química" fez com que as professoras deixassem de reconhecer a água como algo que é utilizado freqüentemente por elas e passasse a significar uma substância de laboratórios (VOGEL et al, 2005). Assim, este diagnóstico inicial mostrou que, para esse público, os conceitos não eram idênticos, como se substâncias químicas diferissem dos materiais que se observam diariamente, sugerindo que sua concepção de Ciência é a de um construto afastado dos fenômenos observáveis na Natureza e no dia a dia.

\section{$5.1 .2 \underline{P R O Q U I M}$}

Partindo do diagnóstico dos mapas conceituais, optamos por elaborar um curso de formação continuada utilizando como material o PROQUIM, um material de proposta construtivista que aborda os conceitos através da diferenciação progressiva. O duplo objetivo do curso era de que esses profissionais adquirissem conceitos relativos às Ciências Naturais e, através de um curso dialógico permeado por atividades práticas, fossem conduzidos à reflexões sobre sua prática docente que, eventualmente, culminassem em modificações em suas aulas.

Das fontes coletadas, foram utilizadas para análise as primeiras e as últimas atividades dos capítulos 1 e 2 do PROQUIM por serem as primeiras perguntas de conhecimento e, as últimas, de síntese e avaliação, segundo a taxonomia de BLOOM (1973). Queremos salientar que a taxonomia de Bloom foi apenas utilizada para classificação das questões. Embora haja controvérsias que vinculam a taxonomia de Bloom ao Tecnicismo, estudiosos defensores da autonomia como parte integrante da construção do conhecimento de alunos e professores como RUÉ (2007) a utilizam para classificar o nível das atividades a serem desenvolvidas para alunos.

Selecionamos para compor o corpo de análise a tabela individual (Tabela I-1, vide figura 5.8 e Tabela 5.1, páginas seguintes), a Tabela de dados (item IV do capítulo I, vide Anexos), o item V (Análise de Dados), o item VII (Exercícios) e o Item VIII (Questões para Discussão) pois estes forneceram dados para verificar como estava a expressão escrita dos 
participantes. As respostas obtidas foram bastante sintéticas e, em alguns casos, as perguntas não foram respondidas. Durante o curso, em ambas as escolas houve queixa por parte dos profissionais de falta de tempo para a realização das atividades em casa, uma vez que é comum que essas pessoas trabalhem em mais de uma escola, quando não em até três. O problema foi amenizado concedendo-lhes os dez minutos finais de cada encontro para que as questões fossem respondidas. A ministrante estava consciente de que esse tempo não seria suficiente para a resolução de todas as questões.

Da análise dos trabalhos derivados da primeira atividade do PROQUIM (Capítulo I - O que é uma reação química, vide Anexo 6) foi construída a Tabela 5.1 que agrupa os resultados de uma atividade em que se propõe aos participantes a listagem de, no máximo, dez transformações do cotidiano (atividade individual). O objetivo dessa atividade é o de resgatar o conceito subsunçor de transformação de cada um dos participantes do grupo, que será diferenciado por meio de uma atividade de discussão coletiva para, posteriormente, cada participante selecionar uma das transformações descritas para a construção de uma tabela coletiva. A atividade foi executada por um total de 24 professores, ao longo dos dois cursos. Dos vinte e quatro (24) trabalhos entregues, apenas em três casos as pessoas não conseguiram executar a atividade, principalmente devido a dificuldades de expressão escrita. Foram analisadas as 21 tabelas individuais produzidas e foi possível depreender que todos os participantes possuíam conhecimentos prévios, em maior ou menor grau, sobre o assunto, como mostram as evocações dos professores discriminadas na Tabela 5.1, que se referem essencialmente a processos.

Tabela 5.1- Transformação e número de evocações

\begin{tabular}{l|c|l|c}
\hline \hline Transformação & $\begin{array}{l}\text { Número de } \\
\text { evocações }\end{array}$ & Transformação & $\begin{array}{c}\text { Número de } \\
\text { evocações }\end{array}$ \\
\hline Alterações climáticas & 3 & Envelhecimento & 5 \\
\hline Amadurecimento & 2 & $\begin{array}{l}\text { Espacial (reorganização do } \\
\text { espaço) }\end{array}$ & 1 \\
\hline Aprendizagem & 1 & Ferimento & 2 \\
\hline Aquecimento & 3 & Fermentação & 6 \\
\hline Azedamento & 1 & Fusão & 3 \\
\hline Ciclo da água & 2 & Operações (cirurgias) & 1 \\
\hline Clareamento & 2 & Outras alterações & 7 \\
\hline Correção & 1 & Oxidação & 2 \\
\hline Cozimento & 5 & Poluição & 2 \\
\hline Crescimento & 5 & Reciclagem & 1 \\
\hline Decomposição & 4 & Resfriamento & 1 \\
\hline Desbotamento & 3 & Secagem & 7 \\
\hline Desenvolvimento & 5 & Solificação & \\
\hline \hline
\end{tabular}




\begin{tabular}{l|l|l|l}
\hline \hline Desidratação & 3 & Textura & 2 \\
\hline Desmatamento & 2 & Tingimento & 7 \\
\hline \hline
\end{tabular}

A análise da Tabela 5.1 mostra que houve predomínio de exemplos relacionados a cozimento (5), crescimento de seres vivos (5), desenvolvimento de seres vivos (5), fermentação (6), solidificação (7) e tingimento (7). Na categoria outras alterações, foram citadas a transformação do creme dental em espuma (2), a transformação de energia potencial em energia elétrica, as modificações ocorridas na pele pelo uso de cosméticos (2) e as alterações que os remédios e drogas causam no organismo. Fica evidente que são situações significativas para esses indivíduos, pois estão relacionadas à saúde, à satisfação de necessidades básicas (alimentação) e à higiene e embelezamento (tingimento de cabelo e de roupas).

A análise das evocações dos educadores evidencia que $84 \%$ deles demonstram compreender um sistema em transformação como processo dinâmico, enquanto $16 \%$ as exemplificaram recorrendo a sistemas estacionários, como mostrado na Figura 5.8. As tabelas construídas pelos professores foram comparadas a tabelas propostas por alunos do Ensino Médio. Os resultados para os professores são muito próximos daqueles dos alunos do Ensino Médio: 87\% dos alunos do Ensino Médio apontaram processos dinâmicos para evidenciar transformações, enquanto alguns alunos (13\%) exemplificaram sistemas em transformação através de processos estáticos, como por exemplo, Milho de pipoca, Gelatina, Refrigerante e Cerveja (BORTOLAl et al, 2007). Estes resultados sugerem que o conceito de transformação associado à alteração de um estado inicial, para que se atinja um estado final, não está claramente construído para cerca de 10 a 15\% dos indivíduos de escolaridade média, na cidade de São Paulo.

Deve-se levar em conta, também, que esses profissionais resolveram o primeiro capítulo do PROQUIM (Anexo 1) com lentidão, provavelmente por não estarem acostumados a redigir respostas a questões que solicitem a articulação entre causas e conseqüências, conforme ilustrado pela atividade mostrada na Figura 5.7. 


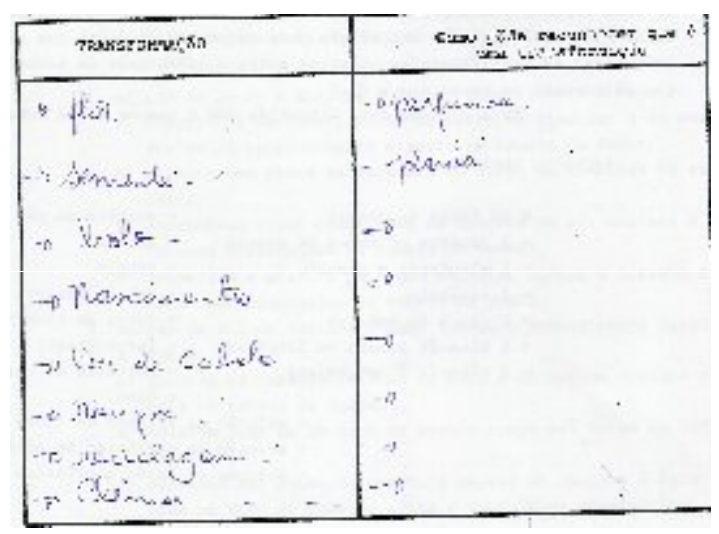

Figura 5.7: Exemplo da tabela individual "Reconhecendo transformações"

Essa falha, constatada durante este curso de formação continuada provavelmente se deva a sua trajetória escolar e também a sua formação inicial, seja na Habilitação Específica para o Magistério (ministrada, até 2003, em nível de Ensino Médio) seja nos cursos superiores de Pedagogia ou Normal Superior. De fato, raros são os professores que tenham experienciado práticas de laboratório durante sua formação inicial, pois essas práticas normalmente não são executadas na maioria dos cursos de Metodologia de Ensino de Ciências ministrado para os futuros professores das séries iniciais (CUNHA e KRASILCHIK, 2005). Ao se formarem, despreparados para o ensino de Ciências Naturais, deparam-se também com a ausência quase que total de cursos de formação continuada que visem sanar essa lacuna.

Posteriormente, os participantes realizaram doze experimentos que envolvia transformações em nível macroscópico e uma em que não era notada transformação neste nível. Os resultados foram anotados no item IV - Tabela de dados conforme demonstra a Figura 5.8. 


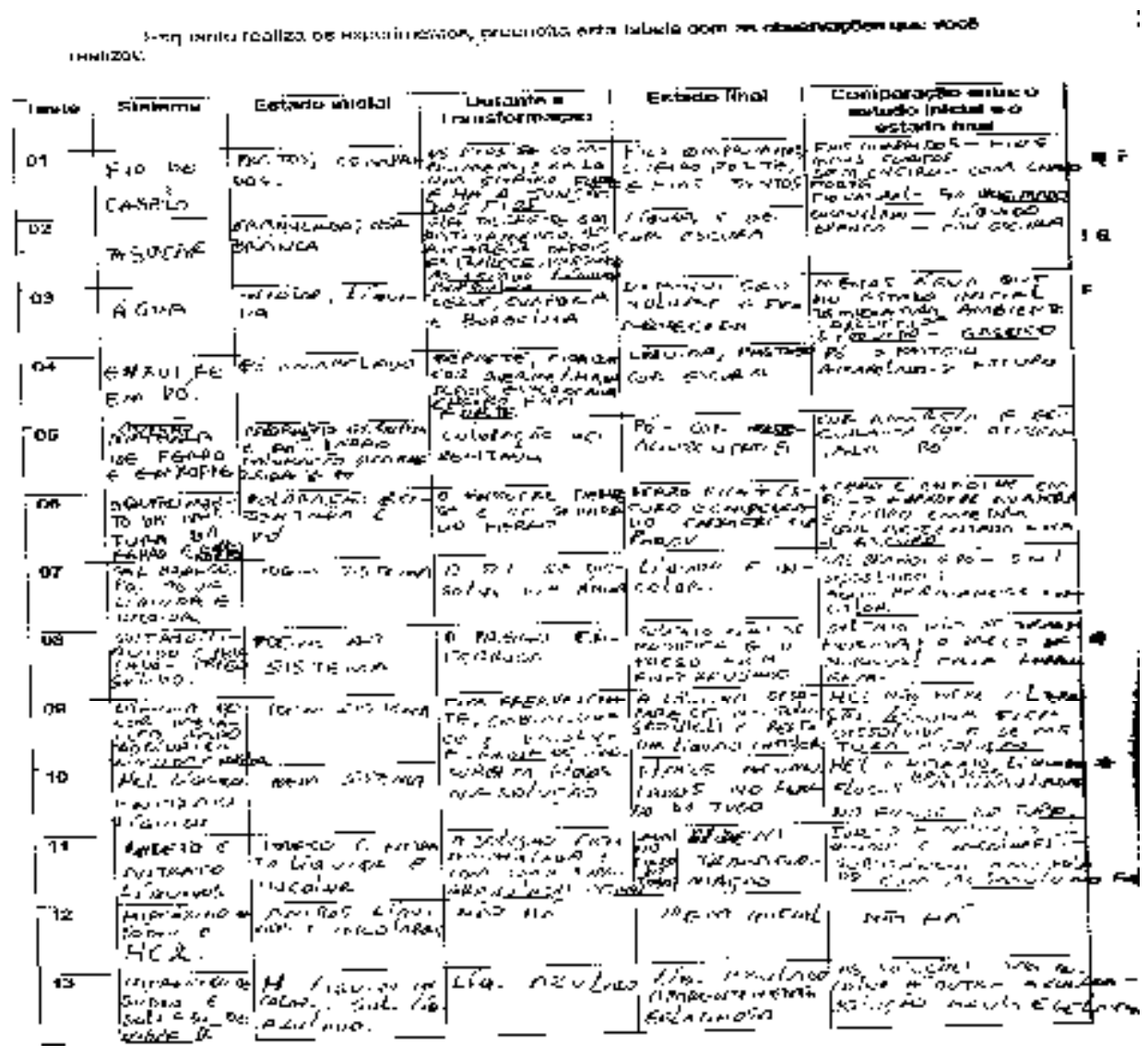

Figura 5.8: Exemplo da Tabela de Dados.

Ao analisar esta, percebemos que todos os participantes foram capazes de identificar, transformações como processo dinâmico o que sugere que os cursos de formação continuada em Ciências devem ter atividades práticas, com intenso manuseio de materiais e objetos para que ocorra a diferenciação dos conceitos. No final do curso, ao finalizar o Capítulo I, três participantes o haviam abandonado por motivos que não foram apurados, permanecendo 18 pessoas. Ao responderem as questões sobre o que foi observado durante a execução do experimento (Item V - Análise de Dados), observou-se que 78\% (14 pessoas) e que estas mesmas pessoas foram capazes de identificar a ocorrência de um fenômeno físico ou uma reação química durante a execução dos exercícios do item VII e que evoluíram quanto à expressão escrita ao responderem de forma satisfatória as questões para Discussão (Item VIII) 


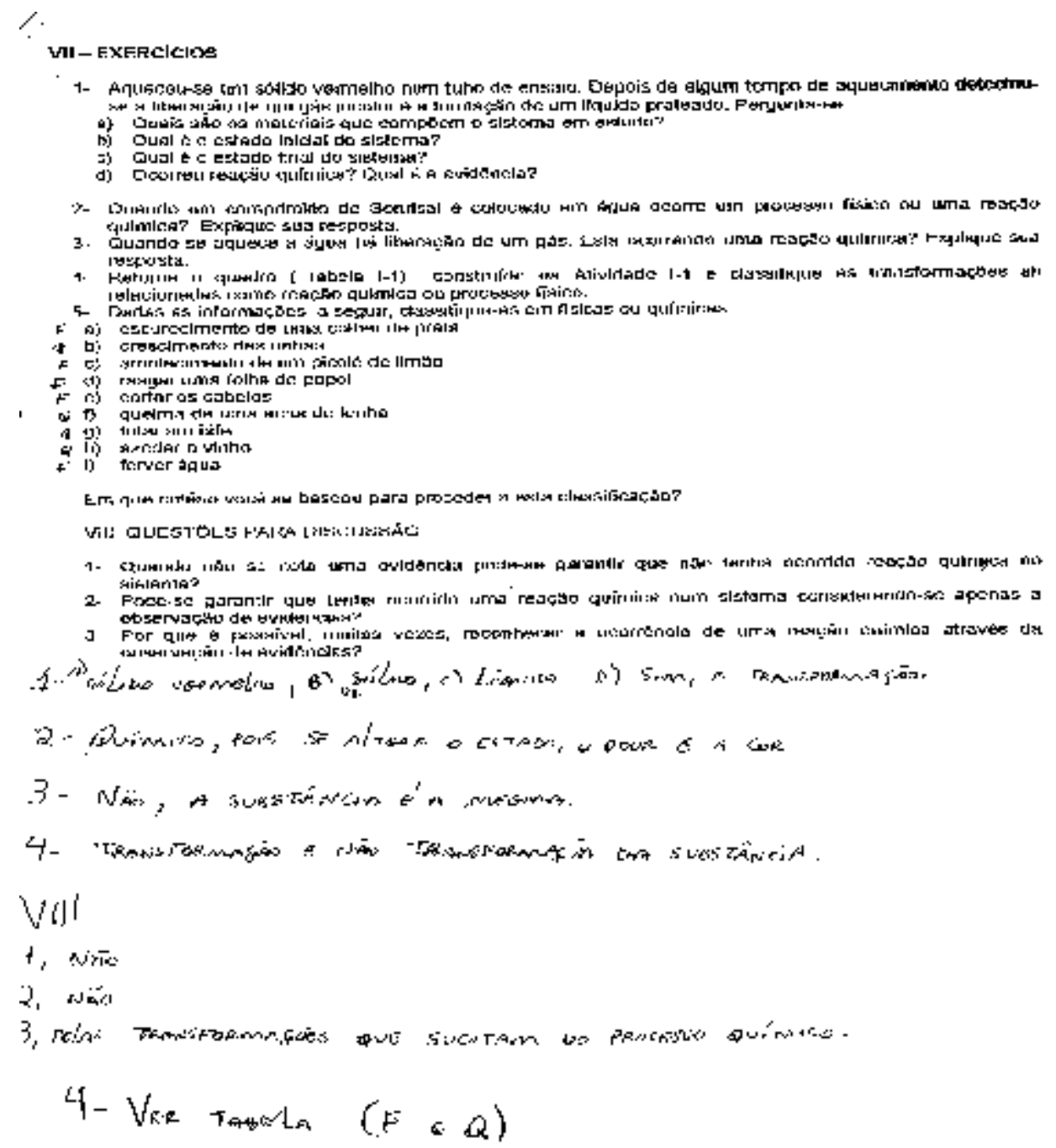

Figura 5.9: Exemplo da atividade VII e VIII -Exercícios

Devido à restrição no Horário de HTPC na E1, cujo tempo tinha que ser dividido com o Coordenador Pedagógico, o curso terminou com a finalização do Capítulo I do PROQUIM. Com os professores da escola E2 foi possível concluir o Capítulo II e realizar uma avaliação sobre o curso. Na etapa inicial do curso, havia 12 professores na E2 e o curso finalizou com 05 participantes. Uma das professoras era de Biologia e ministrava aulas no Ensino Fundamental II e Médio e, por não fazer parte do objetivo dessa Dissertação, seu material não foi analisado. A atividade Ponto de Fusão e Ponto de Ebulição ficou prejudicada porque a quantidade de material empregada para o aquecimento foi muito grande provocando a demora na obtenção nos resultados e, conseqüentemente, restringindo o tempo para responder as questões. Assim, o número de questões respondidas não seria significativo para esta análise. Assim, serão apresentados os dados relativos às questões sobre o conceito densidade. 
No Quadro 5.2 encontram-se as respostas dadas pelos professores a uma das perguntas do experimento (parte A do Procedimento), cujo objetivo era o de construir o conceito de densidade. As respostas sintéticas que apareciam nas questões do Capítulo I desapareceram. Em seu lugar, surgiram respostas completas sobre o que estava sendo observado, no caso, duas barras: uma de ferro e, outra, de alumínio, de $10 \mathrm{~cm}$. Nessa atividade inicial apenas a professora $B$ demonstrou possuir o conceito de densidade. Os demais estavam construindo o conceito de densidade e ainda não o empregavam adequadamente explicitando confusão com o conceito de massa (professores A, C e D).

3-Compare a massa de uma amostra de ferro e de uma amostra de alumínio aproximadamente de mesmo volume. Para isso, segure cada uma delas numa mão. O que você nota?

Professora A: A massa da amostra de ferro é mais densa do que a de alumínio.

Professora B: A amostra de ferro é mais pesada que a de alumínio.

Professora C: A amostra de ferro é mais densa que a de alumínio.

Professora D: A massa da amostra de ferro é mais densa que a do alumínio.

Quadro 5.2: Respostas dos professores sobre a questão 3.

O conceito densidade mostrou-se não construído nas respostas de análise e síntese propostas no item V- Questões para discussão, conforme apontado no Quadro 5.3. Ao ler as questões, percebeu-se a que embora houvesse uma certa melhora na redação sobre causas e conseqüências, não houve apropriação dos conceitos referentes a densidade pois ainda percebia-se claramente a dificuldade dos participantes em explicar os motivos pelos quais o navio não afundava (Questão 2, Quadro 5.3).

2- A densidade do ferro é maior que a da água. Por que um navio de ferro não afunda?

Professora A: A densidade é um dos fatores. $O$ formato também tem importância.

Professora B: A densidade é um dos fatores. O formato também tem importância. $O$ "empuxo", a força da água empurra para cima o navio.

Professora C: A densidade é um dos fatores. $O$ formato também tem importância. $O$ empuxo, a força da água.

Professora $D$ : A densidade é um dos fatores. O formato também tem importância. $O$ empuxo, a força da água. Quanto maior a área. O ferro forma estrutura tridimensional com o ar.

Quadro 5.3: Respostas de análise e síntese do item densidade

O Quadro 5.4 resume os dados analisados nos Capítulos I e II do PROQUIM. Pode-se notar que mesmo com a atividade prática houve uma parcela significativa de indivíduos $(22 \%)$ que não foram capazes de compreender evidências de transformações me nem 
explicar se há possibilidade de ocorrer reações químicas em nível microscópico. $\mathrm{Na}$ segunda parte (Capítulo 2), 75\% foram incapazes de explicar com clareza o conceito de densidade, o que demonstra que estes indivíduos precisam receber formação continuada de forma intensiva e com variadas práticas para que ocorra a construção do conceito em questão. Também devemos observar que o conceito de densidade por combinar outros dois conceitos (massa e volume) envolvendo um terceiro conceito (proporção) acaba dificultando a construção desse conceito por indivíduos que não estejam acostumados a questionar fenômenos observados no cotidiano. Tais resultados corroboram com os estudos de BRAGA (2005) quando afirma que o curso de formação contínua pode oferecer condições para ressignificação dos saberes oriundos de várias fontes externas. O fato de não terem ressignificado o conceito menos inclusivo (densidade) revela a necessidade de utilizar com mais intensidade atividades práticas durante os cursos de formação continuada de professores conforme proposto por RABONI (2002).

Os resultados também revelam que não havia intimidade com o conteúdo por parte dos professores, os motivos já foram explicitados anteriormente: esses professores efetivamente não tiveram acesso a aulas práticas e muito menos a aulas efetivas de Ciências no decorrer de sua formação inicial. Neste caso, concordamos com GUIDO (1996) sobre a importância do um papel do formador especialista junto a um professor polivalente para efetivar a discussão da prática pedagógica, neste caso, em Ciências, uma vez que o professor sozinho sente dificuldade em aprimorar seu trabalho ( GUIDO (1996); ZIMERMAN \& EVANGELISTA (2002) ).

\begin{tabular}{|c|c|c|c|c|c|c|c|}
\hline \multicolumn{2}{|c|}{$\begin{array}{l}\text { Atividades/ } \\
\text { Capítulo }\end{array}$} & $\begin{array}{l}\text { Evocações de "Houve } \\
\text { Ressignificação" }\end{array}$ & $\mathbf{n}$ & $\begin{array}{l}f \\
(\%)\end{array}$ & $\begin{array}{l}\text { Evocações de "Não } \\
\text { Houve Ressignificação" }\end{array}$ & $\mathbf{n}$ & $f(\%)$ \\
\hline \multirow{3}{*}{ 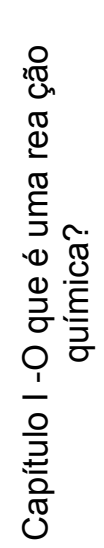 } & $\begin{array}{l}\frac{T}{\frac{\pi}{\pi}} \\
\frac{\pi}{0} \\
\frac{0}{\sigma} \\
\vdash\end{array}$ & $\begin{array}{l}\text { Transformação como } \\
\text { processo dinâmico }\end{array}$ & 18 & 84 & $\begin{array}{l}\text { Transformação } \\
\text { processo estático }\end{array}$ & 3 & 16 \\
\hline & $\begin{array}{ll}\frac{\pi}{0} & 0 \\
0 & 0 \\
\frac{0}{\sigma} & \tilde{\pi} \\
\leftarrow & 0 \\
\geq & 0 \\
\geq & 0\end{array}$ & $\begin{array}{l}\text { Compara o estado } \\
\text { inicial com o estado final } \\
\text { de um sistema. }\end{array}$ & 21 & 100 & $\begin{array}{l}\text { Não compara } \\
\text { inicial estado } \\
\text { sistema }\end{array}$ & 0 & 0 \\
\hline & 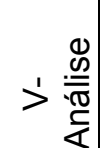 & $\begin{array}{l}\text { Identifica as evidências } \\
\text { de formação de novos } \\
\text { materiais }\end{array}$ & 14 & 78 & $\begin{array}{l}\text { Não identifica evidências } \\
\text { de formação de novos } \\
\text { materiais }\end{array}$ & 4 & 22 \\
\hline
\end{tabular}




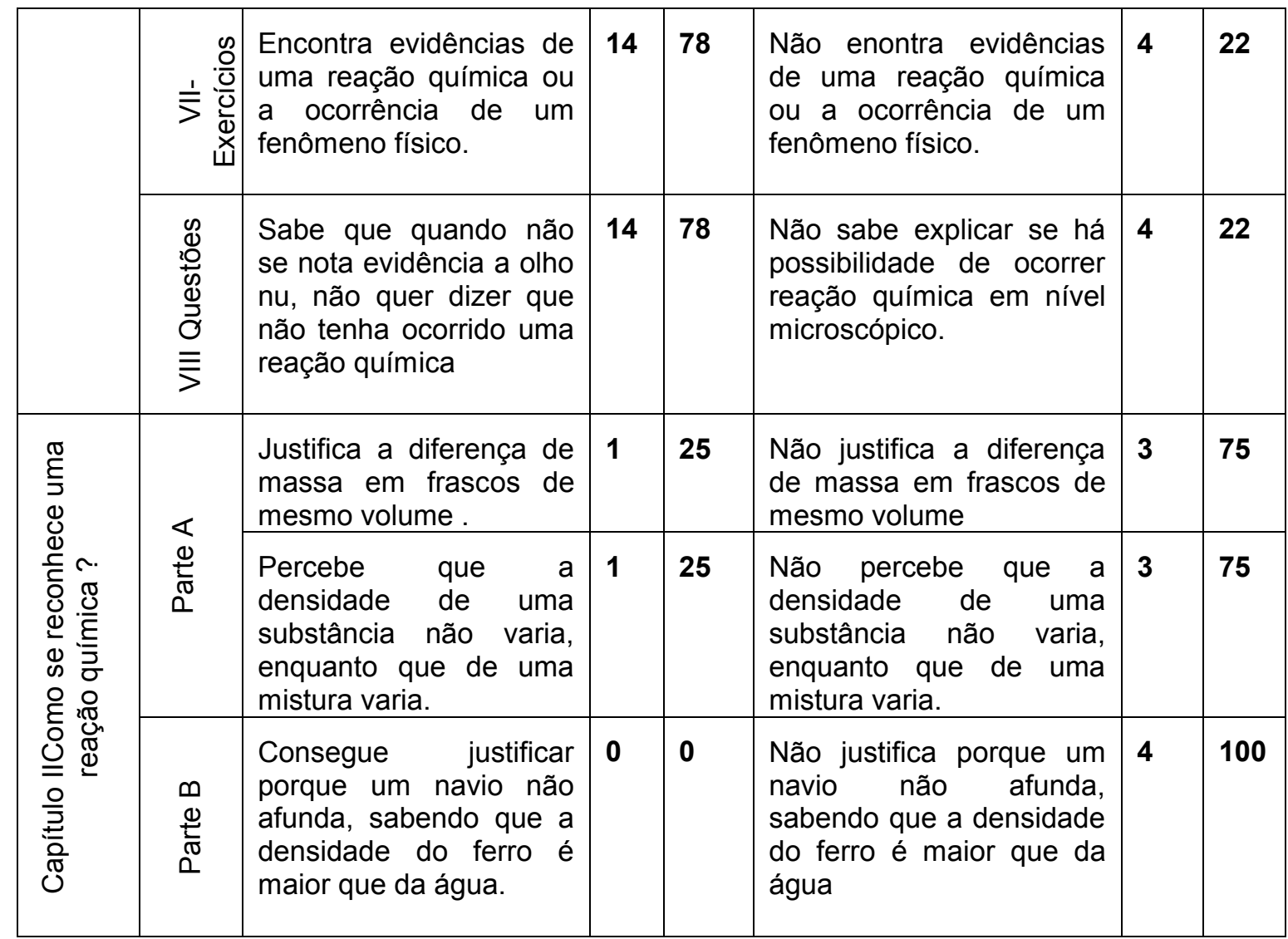

Quadro 5.4: Quadro-síntese dos resultados encontrados

Presume-se que se o curso tivesse mais intensivo, ou seja, com mais horas para a discussão dos conceitos, os professores tivessem efetivamente construído o conceito de densidade na sua totalidade. Ao propor que realizassem uma atividade sobre o tema transformação, viu-se que a transposição didática não foi total, pois constava nos projetos muita confusão entre conceitos de matéria e substância e elemento, além de referências de abordar fenômenos que ocorrem em nível microscópico com crianças (Quadros 5.5 a 5.8).

\footnotetext{
Professora A - Proposta de aula sobre o tema transformação para primeira série

Tema: Transformações

Objetivo: Identificar, analisar e realizar transformações.

Conteúdo: Trabalhar as substâncias químicas nos elementos.

Estratégia: Alimento escolhido: o ovo.

Mostrar o ovo cru como é formado e depois cozinhá-lo.

Através da observação a criança verá que no ovo cru a clara é escorregadia e a gema líquida e de cor amarela. Após o cozimento do ovo, suas substâncias ficarão sólidas, resultando no ovo duro.

Avaliação: Montar um pequeno texto coletivo, ou seja, com a participação dos mesmos. Lançar perguntas sobre o tema abordado.
} 


\section{Professora B - Proposta de aula para o tema transformação para a primeira série}

Tema: Transformação e reações químicas

Objetivo: Levar o aluno a experimentar algumas misturas (preparar cola de água)

Conteúdo: Experiência de elaboração da cola

Experiência: Selecionar o material a ser utilizado: farinha de trigo, água, jornal e prato.

Acrescentar duas xícaras de farinha de trigo a uma xícara de água. Mexer até a massa ficar espessa. A farinha e a água tornam-se uma substância nova, grudenta e pegajosa. Essa é uma reação química envolvendo moléculas de amido, uma das principais substâncias químicas presentes na farinha de trigo.

\section{Quadro 5.6: Proposta de aula da Professora B}

Professora C- Proposta de aula para o tema transformação para terceira série.

Tema: Ferro que enferruja

Objetivo: Levar o aluno a conhecer as causas da ferrugem ligadas à umidade.

Conteúdo: Pequeno texto sobre o conhecimento do ferro e experiência para comprovar que o ferro enferruja.

\section{Texto: 0 ferro é um metal}

O ferro, símbolo químico $\mathrm{Fe}$, é um dos elementos mais comuns nas rochas da Terra. Vemos o ferro como um metal duro moldado em utensílios de cozinha, grades, portões e vigas. Contudo, bem lá dentro da Terra, onde as temperaturas e as pressões são enormes, existem vastas quantidades de ferro líquido.

Experiência: Deixe um prego de ferro novo em um local seco como, por exemplo, no armário. Ponha outro ferro em um lugar úmido, em um canto do jardim. Qual deles irá enferrujar?

Carros, camas e muitos outros objetos velhos contêm ferro e ferrugem. $O$ ferro, quando combinado com a água, forma uma nova substância, a ferrugem, marrom-avermelhada.

Quadro 5.7: Proposta de aula da Professora C.

Professora $D$ - Proposta de aula para o tema transformação para segunda série Tema: Transformações

Objetivo: Identificar, analisar e realizar as transformações.

Conteúdo: Trabalhar a receita de um bolo.

Estratégias: Leitura da Receita

Organizar os ingredientes (ler os rótulos com os alunos). Fazer o bolo com os alunos (em um lugar adequado).

Atentar com os alunos: "Quando sua mãe mistura farinha, ovos, leite, açúcar e fermento e leva essa massa ao forno, você já sabe que vai saborear um delicioso bolo. Mas geralmente nem se dá conta de que a transformação daqueles ingredientes em bolo ocorre graças a uma transformação química.

Comer o bolo

Avaliação: através da participação dos alunos, através das perguntas e observação. Construção de um pequeno texto sobre a aula e o assunto discutido e realizado.

Quadro 5.8: Proposta de aula da Professora D.

As quatro professoras ao proporem aulas sobre o tema transformação também se auto avaliaram a respeito de seus conhecimentos acerca de transformações. A adaptação de textos que provavelmente foram pesquisados em livros didáticos e paradidáticos pelas professoras $B$ e $C$ revelam que essas professoras ainda não atingiram total autonomia para 
preparar uma aula para seus alunos acerca do tema proposto, o que nos faz lembrar as palavras de JUAN RUÉ (2007) que o indivíduo é autônomo ao:

- saber o que está fazendo e tendo auto-controle sobre as finalidades de sua aprendizagem;

- fazer algo que atribui sentido e que Ihe implique de algum modo em seu próprio ponto de vista;

- exercer controle sobre os recursos de tempo, procedimentos e da qualidade do que está executando;

- dispor de algum elemento de apoio como critério de referência e contraste (social, informativo ou procedimental) para avaliar a suas condutas e resultados.

Observamos que todas as professoras utilizaram de materiais e fenômenos que ocorrem no cotidiano e que são significativos para os alunos, muitos dessas transformações citadas por elas durante a construção da tabela I-1, no início do curso. Outro indício de que houve alguma aprendizagem pelas participantes acerca do conceito de sistema é a relativa facilidade com que agora escrevem sobre causas e conseqüências.

O livro didático é um instrumento importante, mas não deve ser estritamente o único meio para se lecionar Ciências às crianças. Aulas criativas como essas são muito melhores do que qualquer texto pronto encontrado em muitos livros didáticos. A importância de que as aulas sejam dialogadas está explícita nas propostas das professoras $A$ e $D$ e de forma implícita nas atividades das professoras C e D.

Os resultados apontados aqui corroboram com os resultados apontados por Guido (1996) e ao realizar sua pesquisa-ação, constatou que a professora com quem trabalhou apresentava falta de intimidade com o conteúdo de Ciências, no nosso caso com conceitos relativos a matéria, substância e elemento químico. Guido ressaltou ainda que é importante a interação de um especialista junto a um professor polivalente para discutir sua prática pedagógica, uma vez que o professor sozinho apresenta dificuldades em aprimorar o seu trabalho. Zimerman \& Evangelista (2002) também relatam que a principal função do formador é ser o facilitador dos saltos cognitivos dos seus formandos.

Assim, para complementar os resultados obtidos, para finalmente podermos responder a nossa pergunta de pesquisa, realizamos entrevistas com professores das escolas E1 e E2 sendo que, na primeira escola, a entrevista se deu dois anos após o curso e, na segunda escola, após ter decorrido um ano do fim do curso. Além das entrevistas, realizamos também a coleta de uma atividade escrita dos alunos sobre o que aprenderam em Ciências Naturais durante o ano letivo. 
A seguir, serão apresentadas transcrições de excertos obtidos por meio de ferramentas da análise do conteúdo, das entrevistas transcriadas dos professores e das redações dos alunos de uma das classes sob sua responsabilidade durante o ano letivo imediatamente subseqüente ao curso de formação, no caso da E2, e no segundo ano após o encerramento do curso, no caso da E1. Dois dos seis professores entrevistados foram categorizados como mostrando influência do curso feito em suas aulas. Os dados referentes a essa categoria (Houve influência) de cada um deles e de seus respectivos alunos constam da seção 5.2, tanto para E1 como para E2. Os dados referentes à categoria Não houve influência constam da seção 5.3. Na seção 5.4 os dados colhidos são a respeito dos relatos sobre a própria formação inicial de todos os professores que participaram da entrevista.

\subsection{Quando Ophelia vive e se torna a Princesa Moana: os professores e alunos que foram influenciados pelo curso.}

\subsubsection{Os professores}

O participante E1A é professor das séries iniciais, titular de cargo efetivo há vinte anos na Rede Estadual de Ensino. Além da HEM possui Licenciatura e Bacharelado em Ed. Artística com ênfase em Artes Cênicas. Leciona preferencialmente para alunos de recuperação de ciclo que são aqueles alunos que praticamente não foram alfabetizados em quatro anos. $A$ professora E2A, assim como seu colega E1A, leciona há 20 anos como professora titular de cargo efetivo e é Licenciada e Bacharel em História.

Em suas entrevistas foram identificados trechos que remetem a quatro subcategorias da categoria Houve Influência, a saber: dialogia (exemplos nos Quadros 5.8 a 5.10), livro didático (Quadro 5.11), experimentação (Quadro 5.12) e mapas conceituais (Quadro 5.13).

Quanto à sub-categoria dialogia, no trecho 28 (Quadro 5.8) o professor E1A relata que o trabalho prático interessa mais aos alunos do que quando se trabalha a teoria oralmente. Já no trecho 201, a professora E2A ressalta a questão de se fazer mais experimentos, que é um trabalho dialógico. Afirma que embora ainda não leve os alunos ao espaço do laboratório, "fuça" nele e, no trecho 203, menciona os mapas conceituais e diz que faz um trabalho inter-disciplinar com o tema água. Ainda reafirma que foi a única experiência que ela teve em curso de formação continuada de que era possível ensinar Ciências no concreto.

O trecho 16 (Quadro 5.9) indica aspectos dialógicos na aula do professor E1A, como mostrado claramente pelo excerto: "a gente descia (refere-se ao jardim interno da Escola, 
que fica no andar térreo), ia lá, fazia anotações, discutia; eles observavam, pegavam e, assim, o interesse de ir todo dia lá para ver o que estava acontecendo". A professora E2A relata no trecho 213 do quadro 5.9 que a atividade experimental é um desafio para os alunos.

\section{Professor E1A}

Dialogia

\section{7-Entrevistadora: Mudou a sua prática depois do curso?}

28-Professor E1A: Então, o que muda, por exemplo, é a gente perceber que, quando você trabalha a prática e não fica só a teoria, é bem mais interessante para os alunos e a aula consegue fluir melhor. É como a gente fez no curso. A gente trabalhava com a prática e a teoria, oralmente.

Professora E2A

199-Professora E2A: Assim, o que eu aprendi no curso, é isso que você está perguntando?

200-Entrevistadora: Assim, ele trouxe alguma coisa para você?

201-Professora E2A: Ah, trouxe, trouxe. Na questão mesmo até de usar mais o laboratório, por exemplo, da escola que tem umas coisas, eu nem sabia que tinha lá. Se bem que eu fuço no laboratório, né. Naquele material todo... eu continuo não indo. Continuo não indo...

Quadro 5.8: Exemplo de trecho referente à sub-categoria dialogia.

O trecho apresentado no Quadro 5.8 mostra que para esses professores, o curso de formação continuada dialógico favoreceu a mudança da prática desses profissionais. Silva (2006) já havia afirmado que um curso de formação continuada deve favorecer o diálogo entre o professor formador e seus alunos e dos alunos entre si. Barros et. al (1998) recomenda também a formação de grupos estáveis de trabalho para discussão de problemas surgidos em sala de aula com a finalidade de se preparar para a realização de mudanças metodológicas mais estáveis em ensino de Ciências. No nosso caso não chegamos a manter um grupo de discussão após o curso com esses professores porque não era o foco do nosso trabalho e também pelo fato do tempo ser restrito.

O Quadro 5.9 também remete à categoria Dialogia direcionando o foco na receptividade dos alunos. É sabido desde Piaget que a criança tem necessidade de manusear objetos para aprender. A atividade experimental favorece este momento, além de promover discussão com seus pares sobre o que está sendo observado. CAPECHI \& CARVALHO (2001) ressaltam que o espaço para a argumentação em atividades experimentais favorece 0 incentivo à cooperação entre os alunos, incluindo ao mesmo tempo o respeito às diferentes explicações e a autoconfiança para posicionamentos contrários aos dos colegas. 


\section{Professor E1A}

15-Entrevistadora: Certo .E qual foi a reação dos alunos frente a essas experiências?

16-Professor E1A: Olha o que deu para perceber é que o interesse é bem maior quando você trabalha com experiência. Essa do pão foi um pouco mais rápida, mas essa da carne, que levou um tempo, então, a gente descia, ia lá, fazia anotações, discutia; eles observavam, pegavam e, assim, o interesse de ir todo dia lá para ver o que estava acontecendo. Uma participação bem maior assim, parece que para eles é muito mais interessante quando é trabalhado experiência.

\section{Professora E2A}

212- Entrevistadora:Você falou para mim que você é uma professora fucenta, que você aprendeu a fazer os experimentos.... como você percebe o momento em que 0 aluno está fazendo os experimentos?

213-Professora E2A: Como eu percebo? Como eu percebo como o aluno fica? Ah, eu acho que fica mais ligado, se interessa mais. E não é mérito meu não, sabe. Acho que você lança um desafio para ele ele quer ver o resultado. Ele quer ver onde vai chegar. Eu percebo isso: eles se sentem desafiados e querem ver o resultado do desafio, eu acho assim.

Quadro 5.9: Exemplo de trecho referente à sub-categoria dialogia, quanto à receptividade por parte dos alunos.

No Quadros 5.10 estão apresentados trechos em que os professores relatam a facilidade da sala em realizar a atividade experimental, desenhá-la e relatá-la e da estruturação da escrita de relatórios. Estes relatos confirmam o afirmado por Bizzo (1995), em artigo sobre metodologia e prática de ensino de Ciências para as séries iniciais do EF:

As ciências contribuem positivamente para o desenvolvimento de outras áreas, principalmente a língua e a matemática (Bizzo (1995).

\section{Professor E1A}

17-Entrevistadora: No que se refere à parte escrita, como é que eles foram? Em relação a escrever relatórios?

18-Professor E1A: Então, o interessante é que eles tiveram facilidade em escrever todo o processo [...]. Fizeram o desenho, [...] escreveram todo o desenvolvimento da experiência.

19-Entrevistadora: Você imaginava que eles pudessem fazer isso?

20-Professor E1A: Não. Quer dizer, imaginava, mas não tão assim profundo como eles fizeram.

\section{Professora E2A}

\section{4-Entrevistadora:E em relação à escrita, você percebe alguma mudança nos relatórios?}

215-Professora E2A: Os primeiros relatórios que eu faço quando eu começo os experimentos. Primeiro faço junto com eles na lousa e vou substituindo as palavras, o que nós podemos usar, como se deu a sequência dos fatos e a finalização. Depois, eu deixo por conta deles. Eles vão fazendo lá os relatos deles. Eu gosto quando eles fazem o relatório, dá certo. Ou seja, em ciências ou geografia, que eles têm que ver o mapa, alguma coisa, eles têm que depois sistematizar, não é? A coerência..... está certo?. Lógico que, aos poucos, eles vão estruturando o texto.

Quadro 5.10: Exemplo de trecho referente à sub-categoria dialogia, quanto à receptividade por parte dos alunos 
$\mathrm{Na}$ categoria livro didático (Quadro 11), no segmento 10, o professor E1A considera o livro didático escolhido interessante e difícil ao mesmo tempo. Esta apreensão também é relatada por CARNEIRO et al. (2005) que ao proporem a oito professores que adotaram o livro Química e Sociedade que respondessem um questionário opinando sobre o livro, ficou constatado que havia uma tensão entre a vontade dos professores em adotar mudanças de estratégias indicadas pelo referido livro e as dificuldades em desenvolver práticas diferenciadas das convencionais. A princípio, a declaração de E1A deixou dúvidas sobre em qual categoria inserir o relato. Ao analisar o material dos alunos, decidimos optar pela aceitação do livro didático, pois, como será discutido adiante, as crianças realizaram uma série de experimentos contidos nesse livro. Já a professora E2A, nos trechos 217 e 219, queixa-se da rapidez com que se tem que escolher o livro didático, o que não permite uma escolha mais criteriosa, além de criticar os colegas que ainda desejam livros não reflexivos. A queixa de que o governo nem sempre envia o livro correspondente à primeira opção de escolha, também é comentado nos resultados da pesquisa feita por MUNAKATA (2002).

A escolha de um livro didático que contenha experimentos e/ou questões pessoais e reflexivas pode ser considerada uma das influências do curso de formação continuada na escola $\mathrm{E} 1$, pois antes, o livro adotado continha somente textos e questionários.

Livro Didático

\section{Professor E1A}

9-Entrevistadora: Esse livro de ciências que foi escolhido... o quê você tem a dizer sobre ele? 10-Professor E1A: Olha acho o livro é até interessante mas ele é um tanto quanto difícil. Quer dizer, o livro é interessante por ter muitas experiências, mas, infelizmente, nem sempre as experiências são feitas. A gente acaba fazendo aquilo que é mais tradicional, não é? Uma vez ou outra a gente acaba fazendo experiência.

\section{Professora E2A}

\section{6-Entrevistadora :Como foi a escolha do livro didático de Ciências neste ano?}

217-Professora E2A : É tão rápido,[...] Para a gente fazer a escolha. ... eles levam os livros lá e colocam trocentos livros na sua frente[...]. Há colegas que ainda querem os livros com o questionário bem grande que é para o aluno responder bastante perguntas. E não aqueles que têm as experiências ou livros que demandam mais análise. E nem sempre o que a gente pede é o que vem. Eu nem me lembro qual que eu pedi, qual que escolhemos. O governo manda o que tiver.

218-Entrevistadora: E a respeito do livro que veio neste ano? Qual a sua impressão dele?

219-Professora E2A: Ah, ele é reflexivo [...] questiona muito as questões ambientais. Esta questão de enchente, de reciclagem, do corpo humano. Eu percebo que ele não muda a seqüência dos conteúdos [...] Só que aparece mais reflexão, tem muitas perguntas pessoais para o aluno estar se colocando, se questionando.... isso, eu acho bacana.

224-Entrevistadora: Poderia ter mais experiência?

225-Professora E2A: Poderia ter mais experiência. [...] eles são mais voltados mais voltados para a questão ambiental de Ciências. [...\} Doenças transmissíveis, dengue,não trazem. [...]

Quadro 5.11: Exemplo de trecho referente à sub-categoria livro didático. 
Os trechos obtidos da transcriação da entrevista dos professores E1A e E2A mostrados no Quadro 5.12 remetem à sub-categoria experimentação. Nos trechos mostrados, os professores descrevem os experimentos realizados em sala de aula, além de fazerem referência explícita às atividades por eles experienciadas no curso de formação, que teriam modificado suas percepções quanto ao papel das aulas práticas em sua prática docente.

\section{Professor E1A}

11-Entrevistadora: Você chegou a fazer alguma experiência do livro? [referência ao novo livro didático adotado na escola]

14-Professor E1A: Aquela que a vida pode surgir de um material não vivo [...] aquela experiência da carne que a gente deixa uma fechada e a outra aberta. Aí, vem a mosca, bota o ovo e vai surgir a larva e vai formar as moscas [...] Essa aí e uma outra do .pão, que foi a parte da transformação do alimento quando se mastiga. Da participação da saliva, na mudança do gosto, até engolir o alimento.

\section{Professora E2A}

\section{6-Entrevistadora: Há quanto tempo você utiliza experimentos nas aulas de Ciências?}

187-Professora E2A: Eu fui procurando livros e caíram nas minhas mãos uns livros de experiência da Biblioteca. Aí fui lendo esses livros e fui vendo a experiências como é que eram. Eram paradidáticos. Através desses livros fui vendo as experiências. Ultimamente, os livros didáticos trazem orientação de como fazer experimentos, o que não tinha antigamente. Isto é de uns cinco ou seis anos para cá. Foram leituras que eu fiz.

\section{8-Entrevistadora: Foram somente leituras?}

189-Professora E2A: Foram leituras de paradidáticos que eu fui procurando, que foram caindo em minhas mãos. Aí, eu fui relacionando conteúdo do livro com esses livros que eu tinha lido e fui cumprindo as experiências. Eu experimentava, não dava certo. Fazia com eles, não dava certo, fazia, aí a gente fazia de novo. Foi mais pesquisa. Mas fui eu mesma. Não foi curso. Nunca fiz curso voltado para Ciências pelo Estado. Nunca fiz.

\section{0-Entrevistadora: Esse livro didático possui experimentos?}

221-Professora E2A: Possui.

\section{2-Entrevistadora: Você chegou a realizá-los?}

223-Professora E2A: Sim. Eu cheguei a realizá-los. Outro que eu vou realizar agora é da eletricidade. A gente vai entrar no tema da eletricidade, no assunto da eletricidade e nós vamos fazer o circuito elétrico. Ele está propondo toda a atividade prática, do pulmão do sistema respiratório, do sistema.... a maioria deles escreveu das estações de tratamento. Mas poderia ter mais. Acho que podia ter mais.

240-Entrevistadora: E a respeito daquele modelo anatômico (torso humano) que você tem ali? Como é que você trabalhou?

241-Professora E2A: Eu deixei eles manusearem. Primeiro, eu pedi para que eles escrevessem o que tinha dentro do corpo. E só saiu as tripas como eles falam. As tripas. Tripa e coração (risos). Quando eles viram a "Eva" e a desmontaram. Eles gostaram. Foi mais fácil trabalhar com aquilo lá. Mas aí eu falei para eles. Isso aqui está duro. $O$ da gente é todo molinho por causa dos tecidos [...] Eu acho que é bom. Grava, fixa. Sai do abstrato, vai para o concreto. Eu não deixo mais ela no laboratório não. Porque lá vai ficar só enchendo de poeira e coberta. Achei que foi bom.

Quadro 5.12: Trechos referentes à sub-categoria experimentação.

A professora E2A relata que já realizava práticas experimentais nas suas aulas de Ciências. Ao relatar como foi trabalhado o torso humano com seus alunos, podemos 
verificar mais uma influência do curso de formação continuada porque a professora, antes de entregar o material para ser manuseado, quis saber quais eram as concepções que os alunos tinham sobre a parte interna do corpo humano, assim como foi feito durante o curso, ao se investigarem as concepções dos professores sobre o conceito água e sobre substância química água e, posteriormente, sobre transformação. Observa-se conforme já relatado por Zembal-Saul et al (2000) que quando o professor compreende os processos de aprendizagem dos alunos, há melhoras no conteúdo dos ciclos de instrução produzidos pelos professores.

Uso de Mapas Conceituais

\section{Escola E1}

Entrevistadora: Por que você resolveu utilizar os mapas conceituais durante as aulas de Ciências?

Professora 1 [...] tudo que é proposto eu tento aplicar.

Entrevistadora: $\mathbf{O}$ que levou você a confiar no método e levar para a sala de aula?

Professora 1: Eu quero me inovar e quero melhorar a qualidade de minhas aulas. Eu estou acreditando no que me está sendo passado. Fiquei surpresa ao trabalhar a elaboração dos mapas coletivamente e vi quanto as crianças sabiam sobre água. Não sabia que eles tinham um conhecimento prévio tão bom.

Entrevistadora: Como os alunos reagiram a esta proposta?

Professora1: Eles tiveram participação total. Eu trabalho de forma oral. Percebi o grande envolvimento dessas crianças.

Entrevistadora: Você encontrou alguma dificuldade em envolver os alunos com esta técnica?

Professora 1- Não foi muito bom.

Entrevistadora:Mas, e na sua prática depois do curso?

Professora E2A: Tem o mapa conceitual que eu não sabia fazer dentro de Ciências e, aí, levei para as outras matérias. [...], levo para outras disciplinas: faço com história, faço com geografia. A questão de fazer a prática também, a experiência....que é possível dar aula de Ciências no concreto, assim. Foi a única experiência que eu tive, viu?. Eu nunca tive um curso assim não.

Quadro 5.13: Relatos dos professores quanto ao uso do mapa conceitual.

$\mathrm{Na}$ escola E1, entrevistou-se na época do curso de formação continuada a Professora 1 que relatou a vontade de mudar a própria prática e a surpresa de saber que alunos de primeira série possuíam conhecimentos que ela não imaginava e que esses conhecimentos acabaram por ajudar na abordagem do tema e no processo de aprendizagem. A disciplina Ciências é vista como um componente crítico do acesso necessário para fazer a mudança da realidade em sala de aula, conforme apresentado por GALLACHER (2000).

$\mathrm{Na}$ escola E2, a entrevista se deu após um ano do término do curso de formação continuada. A entrevistadora pode constatar que, para a professora $E 2 A$, o aprendizado da 
construção do mapa conceitual foi marcante, pois a mesma fazia uso da metodologia em outras aulas que não de Ciências

A professora 1 mudou-se de escola durante a investigação e não foi possível verificar se ainda continuava a utilizar-se de outros recursos apontados no curso de formação continuada em sua prática docente. A professora E2A não havia concluído o curso na sua totalidade, mas, por ser efetiva, foi possível verificar na entrevista e na atividade das crianças se haviam reflexos do curso em sua prática.

\section{$\underline{5.2 .2 \text { Os alunos }}$}
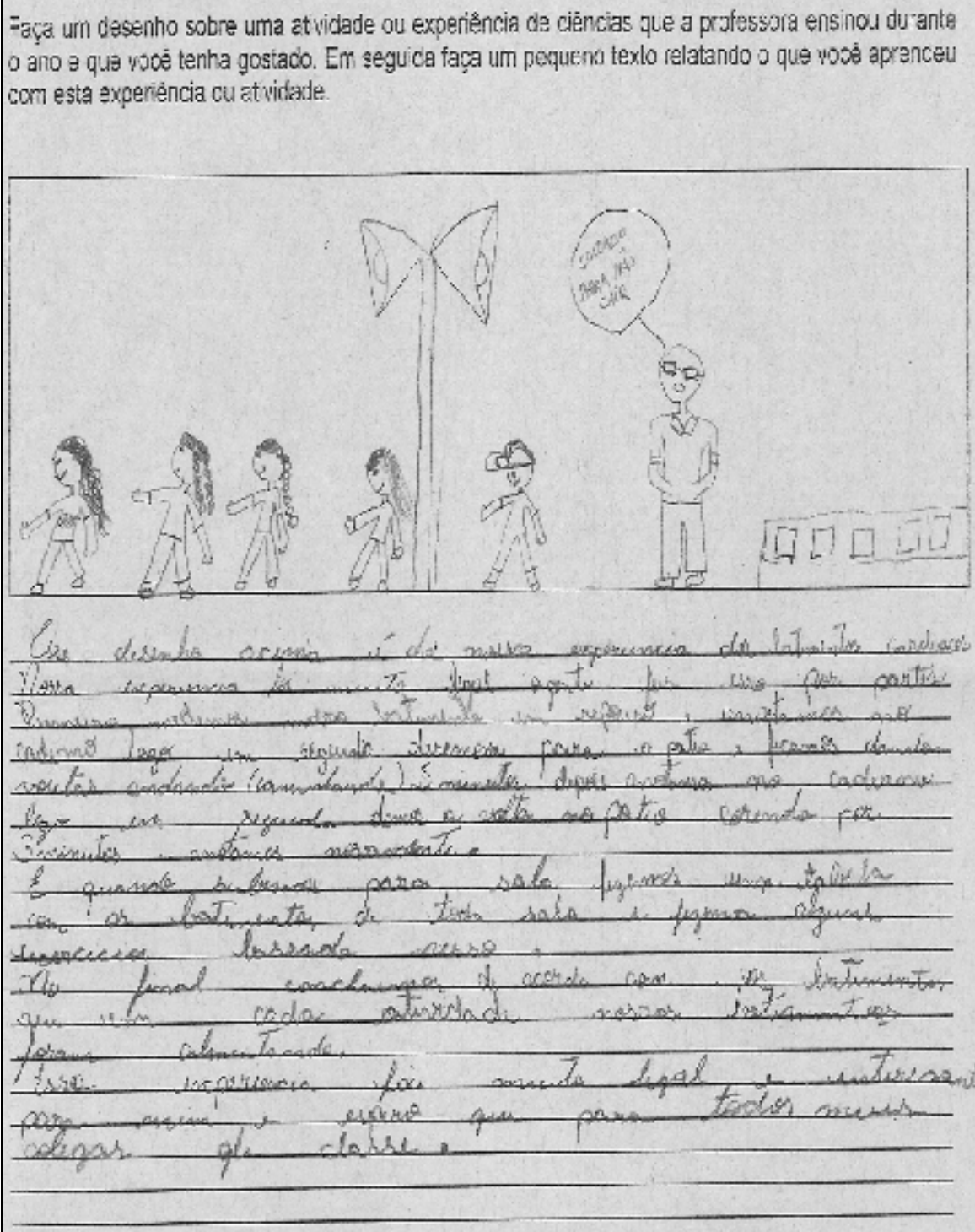

1-Esse desenho acima é da nossa experiência dos batimentos cardíacos. 2-Nossa experiência foi muito legal a gente fez isso por partes. 3-Primeiro medimos nosso batimento em repouso e anotamos no caderno, logo em seguida descemos para o pátio e ficamos dando voltas andando (caminhando) por cinco minutos depois anotamos no caderno logo em seguida demos a volta no pátio correndo por 3 minutos e anotamos novamente. 4E quando subimos para a sala, fizemos uma tabela com os batimentos de toda a sala. Fizemos alguns exercícios baseado nisso. 5-No final concluímos de acordo com os batimentos que em cada atividade nossos batimentos foram aumentando. 6-Essa experiência foi muito legal e interessante para mim e espero que para todos os meus colegas de classe.

Figura 5.10: Atividade de um aluno de $\mathrm{E} 1 \mathrm{~A}$, trechos referentes à sub-categoria experimentação. 
Os alunos de E1A são alunos da quarta-série recuperação de ciclo e relataram exclusivamente atividades práticas, sendo que essas práticas foram aquelas também citadas pelo professor. Embora o professor tenha relatado que, às vezes, apela para o "tradicional", durante a pré-analise do material dos alunos ficou constatado que dos 29 alunos de E1A, 27 apresentaram relatos de atividades experimentais (Figura 5.10), sendo que apenas 2 não as relataram de forma legível, embora seus desenhos parecessem remeter à Experiência de Redi ${ }^{1}$. Dos experimentos relatados, 16 eram referentes à Experiência de Redi (59,3\%), 8 à pulsação e circulação sanguínea humanas (29,6\%), 1 se referia ao corpo humano $(3,7 \%)$ e 2 à Experiência do Amido (7,4\%). A média de linhas escritas por esses alunos ficou em 8,74 linhas.

Os segmentos 1 e 2 (Figura 5.10) já evidenciam que a aula do professor é dialógica devido à presença dos pronomes em primeira pessoa do plural (nossa experiência), além do termo a "gente fez" denotar que a atividade foi realizada em grupo. Nos segmentos 3, 4 e 5 há descrição detalhada do experimento acompanhada da conclusão, denotando que a criança realizou e compreendeu a atividade experimental.

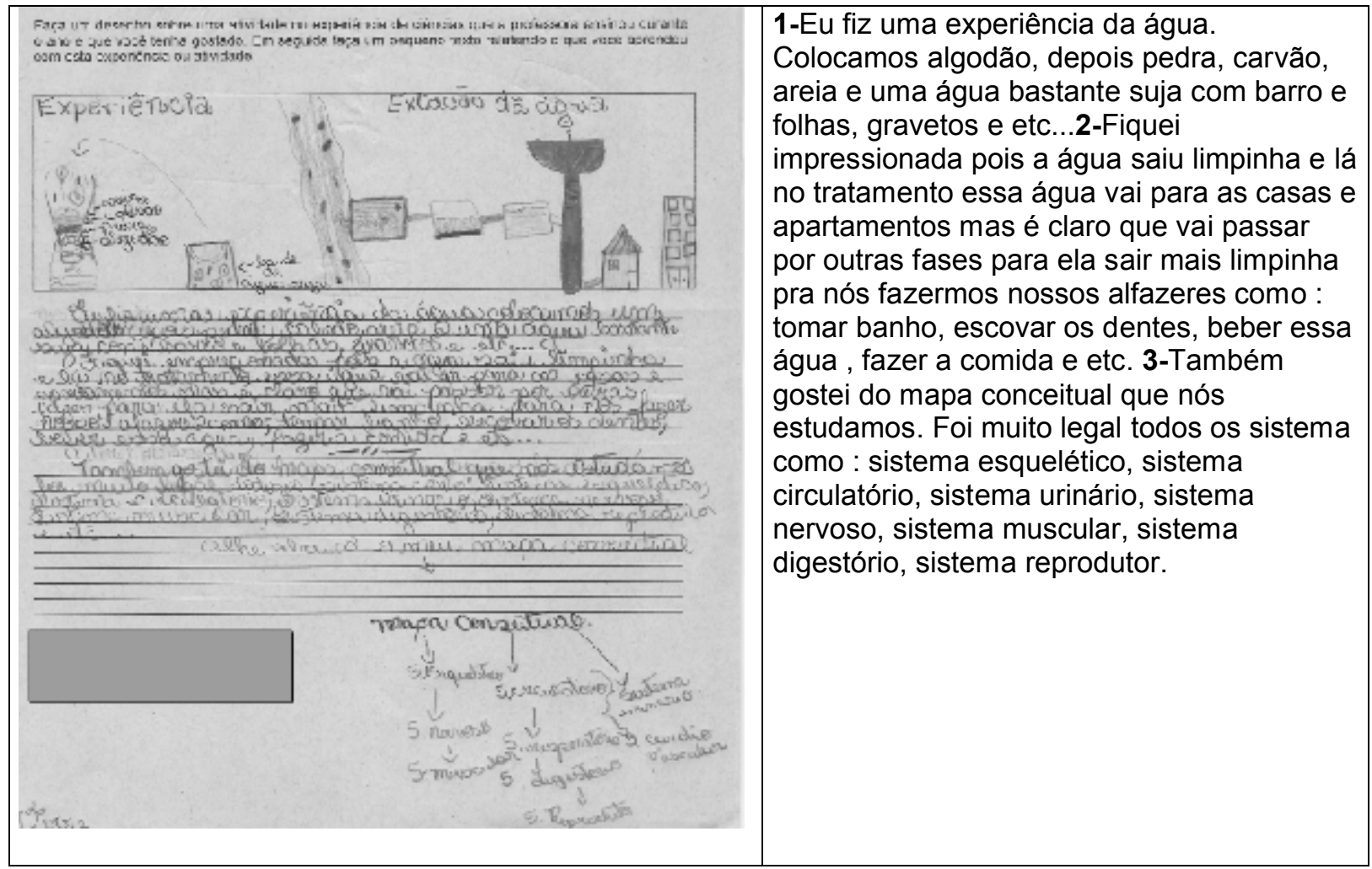

Figura 5.11: Atividade de um aluno de E2A.

\footnotetext{
${ }^{1}$ A experiência de Redi é utilizada para provar que não há geração espontânea de seres vivos e consiste em colocar pedaços de carne em dois recipientes um destampado e outro coberto de gaze. Com o passar do tempo, a carne entra em estado de putrefação e, conseqüentemente atrai moscas que ali depositarão ovos no recipiente descoberto. O outro por estar fechado não haverá deposição de ovos e nem eclosão de larvas provando-se assim, que não há geração espontânea.
} 
No trecho 1 (Figura 5.11), o pronome em primeira pessoa do singular empregado pela criança ao narrar o experimento que realizou demonstra ser ela o sujeito do experimento. Em seguida, a narração feita em primeira pessoa do plural, dá a idéia de que a atividade foi realizada em grupo. No trecho 2 , narra sua surpresa ao verificar que a água saiu bem mais limpa do que a que tinha colocado no filtro e complementa que, numa estação de tratamento de água, ela irá passar por outras etapas. Toda esta narrativa pode ser considerada uma polifonia do curso de formação continuada, pois o conceito água foi abordado no início do curso. No trecho 3, a criança faz referência ao mapa conceitual e faz uma ilustração deste. Embora o mapa não esteja tecnicamente correto pode ser considerado por ter sido feito por uma criança que ainda está aprendendo a utilizar esse recurso. A aprendizagem da realização de mapas conceituais por crianças envolve mais tempo do que para adultos porque requer organização de conceitos (mais inclusivos para menos inclusivos). Após o mapa conceitual, a criança desenhou, sem consulta a livros ou cadernos, um esboço do sistema respiratório nomeando adequadamente os órgãos pertencentes a este sistema (Figura 5.12).

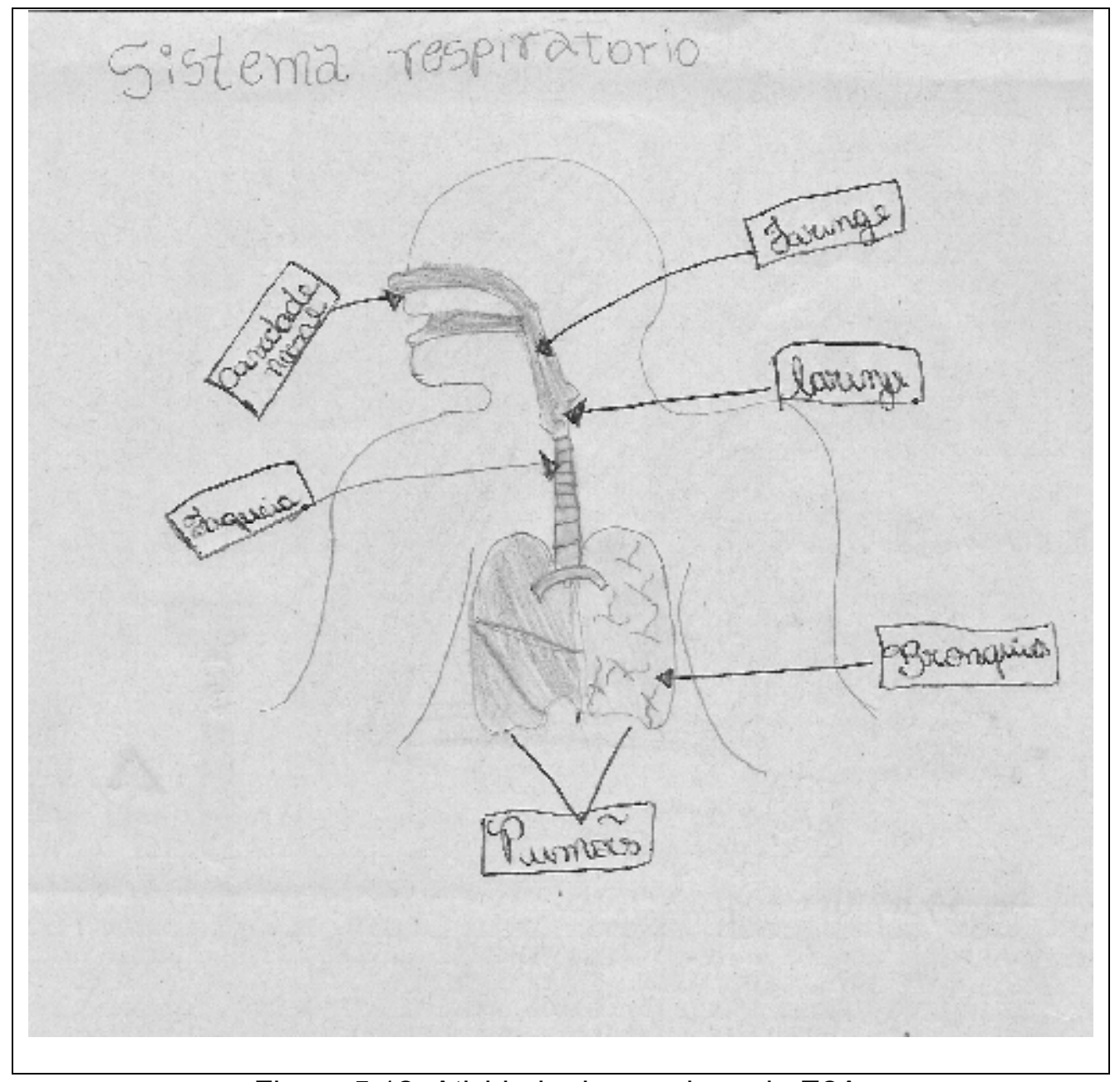

Figura 5.12: Atividade de um aluno de E2A. 
Analisando-se a Figura 5.12 percebe-se que a criança tem clareza de que pode haver vários órgãos em um sistema; neste caso, ela está utilizando o conceito mais inclusivo, sistema respiratório, para adicionar os menos inclusivos, que são os órgãos que fazem parte desse sistema.

Em suas atividades, os 23 alunos da quarta série de E2A escreveram, em média, 10 linhas. Treze alunos relataram a filtração da água (57\%); os sistemas nervoso, esquelético, urinário, muscular, digestório e reprodutor foram mencionados por três alunos (13\%) cada um, 4 falaram sobre o sistema circulatório (17\%), 05 sobre o corpo humano de forma generalizada (22\%), 02 sobre o sistema respiratório (9\%), 01 sobre poluição $(4,5 \%)$ e 02 sobre a cadeia alimentar (9\%). Desses alunos, apenas 01 não conseguiu expressar-se de forma escrita ou através de desenho. Dos 23 alunos, 13 fizeram relato de experiência $(57 \%)$ e 03 relataram o uso do modelo anatômico (13\%). Alguns alunos ficaram tão empolgados com a atividade que 05 relataram mais de um experimento/atividade no espaço da folha $(22 \%)$.

$\mathrm{Na}$ Tabela 5.2 encontram-se os resultados da análise do material dos alunos de E1A e E2A, referentes à categoria Houve influência.

Tabela 5.2: Evocações dos alunos pertencentes à categoria Houve influência

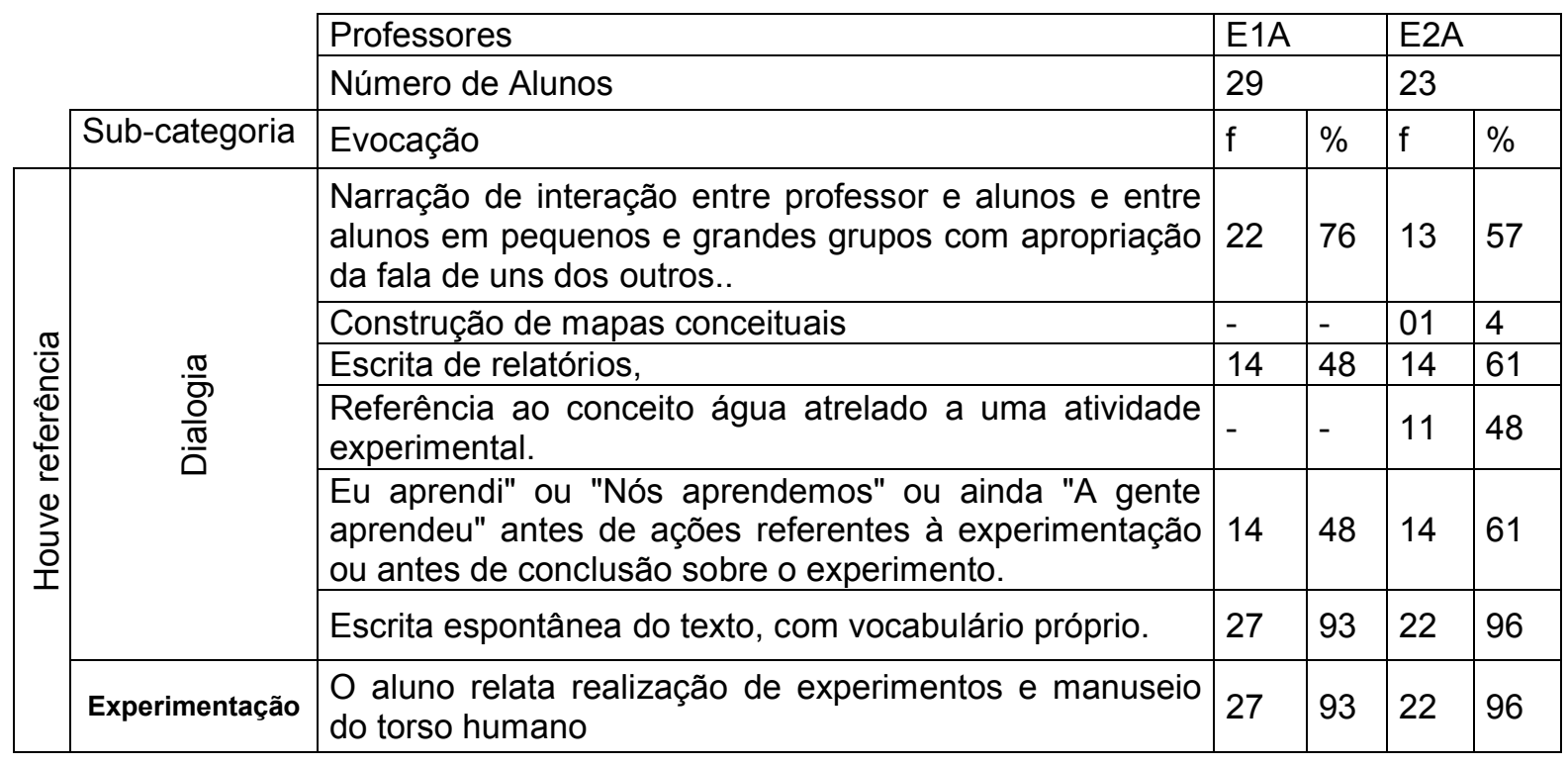

As porcentagens de relatos referentes à experimentação e dos quais denotavam-se práticas dialógicas são muito próximas em ambas as classes de E1A e E2A, embora E2A tenha relatado que já utilizava-se de aulas experimentais na sua sala, admitiu que utilizou-se dos mapas conceituais para ministrar suas aulas, além da maneira como coordenou o manuseio do torso humano pelos alunos, revela que o curso acentuou sua prática docente. 
5.2 Quando Ophelia morre nas mãos do general: os professores e alunos que não foram influenciados pelo curso.

Nesta categoria foram inseridos os professores que não mudaram a sua prática docente após o curso de formação continuada. Esses professores possuem perfis semelhantes de formação e de experiência docente que foram descritos no Capítulo IV - Metodologia.

Nos relatos dos professores encontramos expressões que remetem ao tipo de formação recebida que, no caso é a tecnicista, tais como: (i) a ênfase no ensino de Português e Matemática (E1B); (ii) ênfase no conteúdo e nas aulas expositivas (E1C); (iii) a espera por receber um material pronto, sem que haja reflexão e construção do mesmo pelo professor (E2B); (iiii) a ausência de aulas práticas em ciências por priorizar a alfabetização.

Será que não é possível alfabetizar uma criança através do ensino de Ciências? Uma pergunta que será respondida em outro momento.

\section{Professora E1B}

\section{(Expressões Tecnicistas)}

46-Entrevistadora: E você sente falta da prática?

47-Professora E1B: Sinto. Sinto.

48-Entrevistadora: E como isto interfere no seu trabalho?

49- Professora E1B:[...] Acabo deixando de lado porque o que é mais importante? O Português e a Matemática.

\section{Professora E2B}

323-Entrevistadora: Aquele curso do ano passado o que ele trouxe você?

324-Professora E2B: Ele é mais útil para terceira e quarta série. Porque na primeira e segunda série eles são muito novinhos para trabalhar aquilo que trabalhamos.

325- Entrevistadora: O que você mudaria naquele curso?

326-Professor E2B: Eu não mudaria nada,só gostaria que ele estivesse mais voltado para a primeira série.[...] E eles são imaturos. Eles vem para nós com o que? Seis anos.

\section{Professora E1D}

146-[...]Eu não fiz mais porque eu tinha que alfabetizar. (referente a não realização de atividades experimentais).

Quadro 5.14: Referente a Expressões tecnicistas.

Os resultados apresentados estão em consonância com os descritos por CARVALHO (2009) que ao entrevistar 11 professores pertencentes à área de Ciências Biológicas que 
lecionavam no final das séries iniciais em Aparecida de Goiânia (GO), dos quais 6 tinham mais de vinte anos de experiência verificou que 9 desses docentes apresentavam concepções tecnicistas em relação ao ensino da educação ambiental.

O Quadro 5.15 refere-se à sub-categoria monologia. Pode-se notar que os professores destacados não foram capazes de referir-se à atividade experimental como processo dialógico porque não descrevem as etapas do processo como os professores E1A e E2A fizeram em "houve influência" o que faz lembrar o dito de Freire (2001, p.54):

Numa tal concepção é evidente que os alfabetizandos sejam vistos como puros objetos do processo de aprendizagem da leitura e da escrita, e não como seus sujeitos. [...] sua tarefa é 'estudar', quer dizer, memorizar as assim chamadas lições de leitura, de caráter alienante, com pouquíssimo que ver, quando têm, com a sua realidade sociocultural.

\footnotetext{
(Monologia )

\section{Professora E1B}

56-Entrevistadora: Você chegou a desenvolver alguma atividade prática de ciências? E como foi o interesse de seus alunos?

57-Professora E1B: Foi...teve um bom resultado. Até aqueles mais assim, acabaram se interessando.

58-Entrevistadora: E eles acabaram fazendo um relatório da experiência que fizeram?

59-Professora E1B: Sim, mas neste ano não.

60-Entrevistadora: Então neste ano eles não tiveram atividade prática?

61-Professora E1B: Não. Não.

\section{Professora E2C}

287-Entrevistadora :Você chegou a aplicar alguma experiência?

288- Professora E2C: Você diz a experiência do curso aqui? Acho que foi uma só que eu apliquei.

289-Agora eu não me lembro direito porque foi logo no início do ano. Foi logo no início do ano...eh não estou lembrada qual é. .....porque eu não quis pegar o material que a gente usou do laboratório.

303-Entrevistadora: Eles chegaram a fazer relatório dos experimentos?

304- Professora E2C: Do que eu fiz eles fizeram.

305-Entrevistadora: E em relação à escrita do relatório, o que você notou?

306- Professora E2C: Eu notei que as idéias ficam mais explicitas no relatório, mas precisam de algumas correções que a gente precisa fazer com eles, né? Erros ortográficos que é normal, né?
} 
No Quadro 5.16 estão inseridos os excertos sobre aulas em que houve demonstrações de atividade experimental.

É importante ressaltar que mesmo a professora relatando que os alunos realizam pesquisa, pela análise das atividades dos alunos (mostrada a seguir), percebe-se que eles escrevem de forma não espontânea.

A professora E1D revela explicitamente que fez uma atividade de demonstração apenas no ano anterior.

Diversos trabalhos científicos relatam que experimentos demonstrativos quando devidamente empregados podem auxiliar a enfocar a atenção do estudante, além de aumentar-Ihes o conhecimento e a consciência do fenômeno a ser estudado. Dentre eles podemos citar os artigos escritos por Arroio et al (2006) e Barreiro \& Bagnato (1992). Por outro lado, também existem críticas a respeito dessa metodologia como o trabalho de Plicas (2005). No caso desta Dissertação nós criticamos essa prática com crianças porque elas têm necessidade de manipular os materiais para compreender o que se passa. Notamos embora empregassem aulas demonstrativas, os professores demonstraram um certo desconforto por não saberem explicar os experimentos realizados. Notamos também que esses profissionais possuem dificuldade em utilizar em suas aulas livros mais reflexivos e que apresentam atividade experimental.

\section{Demonstração}

\section{Professora E1C}

91-Entrevistadora: Com todas essas dificuldades que você teve,você chegou a trabalhar com eles ciências?

92-Professora E1C: Ciências....ah trabalhei muito com ciências com eles. Em ciências trabalho mais com pesquisa. Com observação, com trabalho também feito em sala de aula, trabalho feito fora da sala de aula, pesquisa na Internet. Pedi para que eles observassem a natureza.

\section{Professor E1D}

145-Entrevistadora: Você chegou a trabalhar algum experimento em sala de aula?

146-Professora E1D: Não. Eu trabalhei no ano passado. Fiz a experiência da áqua e do óleo. Porque o óleo não mistura com a áqua. Eu fiz tudo isso aí[...].

Quadro 5.16: Referente a demonstração

Nota-se em muitos casos a ausência do livro didático, ou então em quantidades reduzidas para atender a demanda em sala de aula como mais um elemento dificultador do trabalho docente. Há rejeição por parte desses professores que não foram influenciados 
pelo curso de formação continuada do livro didático com questões mais reflexivas por não terem domínio dos temas que serão abordados em sala de aula.

\section{Livro Didático}

\section{Professora E1B}

64-Entrevistadora: E o que você achou do livro didático de ciências?

65-Professora E1B: Não gostei. Modéstia a parte não utilizo. Eu utilizo outros livros, outros recursos, né? Eu acho que é muito extenso e não dá tempo de você dar.

67-Professora E1B: [...] muito complexo.

69-Professora E1B: [...] tem muita coisa que não dá para desenvolver com eles; [...] precisa de uma pessoa para estar orientando a gente [...]

\section{Professora E1C}

110-Entrevistadora: E como foi essa escolha do livro didático?

111-Professora E1C: [...]os livros já estavam pré-escolhidos para o professor olhar.[...].não tinha nada para o professor fazer[...] . A minha opção acabou sendo essa. que eu não gostei. Nós gostamos de mudar de assunto também.

114-Entrevistadora: E o livro de ciências?

115-Professora E1C: [...] está muito teórico. [...] deveria ser mais baseado na reflexão [...] para colocar o aluno para pensar. [...]

\section{Professora E1D}

153-Entrevistadora: Você chegou a receber o livro de ciências?

154-Professora E1D: Não. Só o de história e de geografia.

\section{Professora E2B}

321-Entrevistadora: Você usou livro didático?

322-Professora E2B: Não,Porque só tem o nosso. Eles não tem.

281-Entrevistadora: E como que você avalia esse livro de ciências que eles têm?

Quadro 5.17- Referente à sub-categoria livro didático de Não Houve Referência

\subsection{Os reflexos sentidos pelos alunos}

Ao realizar a pré análise do material dos alunos, obtivemos os seguintes resultados:

As crianças de E1B (24), como era de se esperar não relataram atividade prática. Os assuntos abordados foram exclusivamente de leitura e compreensão de textos. Dentre esses alunos $4(17 \%)$ não entregaram a atividade, 2 (8\%) mencionaram Sistema Solar, 5 (21\%) movimento de rotação da Terra, 5 (21\%) movimento de translação da Terra, 3 (13\%) Sol, $1(4 \%)$ fez texto relacionado a data comemorativa, 1 (4\%) não entendeu o que fazer, $1(4 \%)$ sobre a prenhez da macaca Michelle Pfeifer, 1(4\%) sobre aquecimento global e 1(4\%) sobre água. A média dos textos escritos desses alunos eram de 3 linhas. 
Já era esperado que as atividades das crianças revelassem aulas de cunho tecnicista e monológica, pois na entrevista a professora já havia relatado que possui grande dificuldade em ensinar ciências. Esta dificuldade é também revelada nos tema que foi abordado com os alunos em ciências, predominantemente sobre o Sistema Solar. O baixo número de linhas escritas revela a dificuldade das crianças em produzir os seus relatos e desenhos confirmam essa situação.

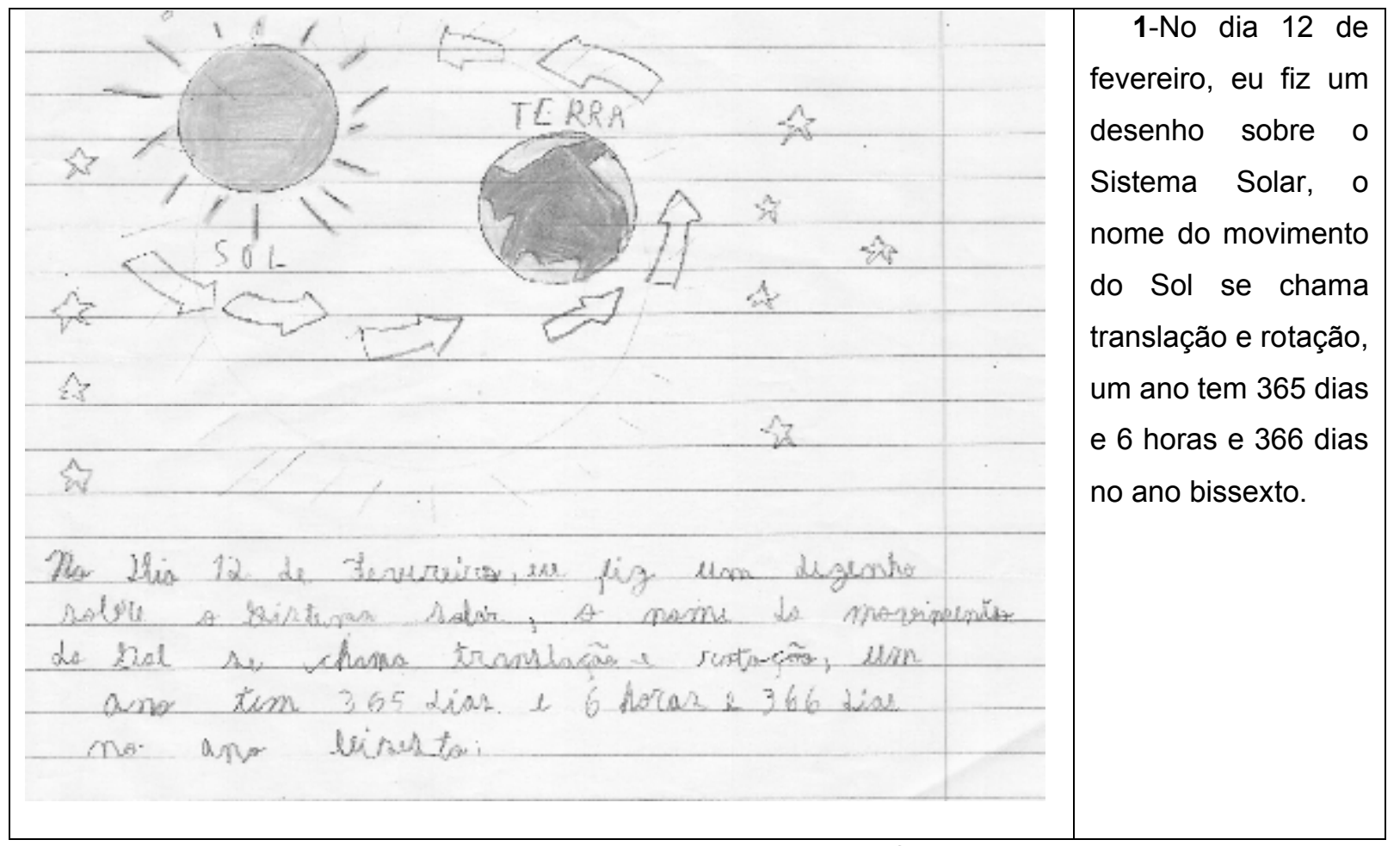

Figura 5.13: Atividade de aluno da professora E1B

Este trecho revela bem o tipo de aula que esta criança assistiu: exclusivamente monológica, tendo teoria como meio de aprendizado (ainda sobre um tema da Astronomia que é de difícil compreensão). Pela maneira que esta criança escreveu ainda está revelada que esta aula ficou restrita apenas a reprodução de texto escrito na lousa pela professora ou copiado de um livro que remete ao tipo de aula predominante que a professora provavelmente recebeu durante a sua formação na HEM. Embora não faça parte do escopo de análise, a data 12 de fevereiro é a data que esse aluno provavelmente estudou esse tema. A coleta de dados para análise deu-se em 23 de novembro do mesmo ano. Provavelmente este foi a única aula do aluno sobre Ciências. 


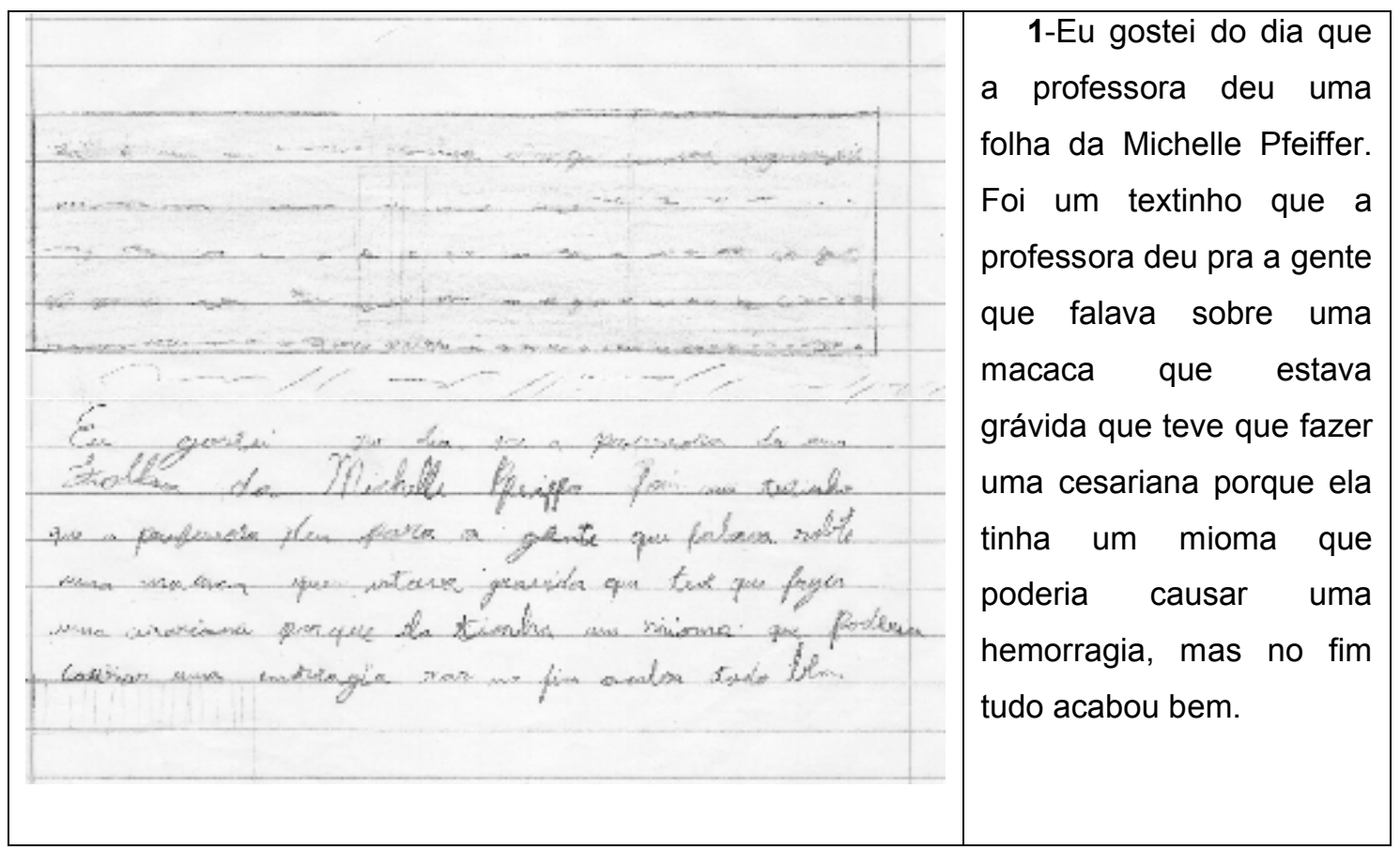

Figura 5.14- Atividade de aluno da professora E1B

Novamente, uma aula exclusivamente monológica com cópia de texto escrito. Não há indícios de interação com professor e com os demais colegas. A criança apenas reproduz a informação. Será que a criança sabe o que é um mioma?

Foram 17 crianças de E1C que participaram da atividade. As crianças citaram predominantemente temas ligados a ecologia como aquecimento global (2), economia de água (12), sobre a natureza de forma geral (1) e sobre a poluição sonora (1). Dos textos analisados (1) reproduziu texto de caderno ou livro, (1) relatou sobre a experiência da gota d'água, (1) criança fugiu do tema. A média de linhas escritas nessa classe foi de 7,5.

Percebe-se que predominou o ensino tecnicista com aula monológica. A grande maioria (88\%) relatou ausência de interação com o professor e com o grupo de sala de aula. Os desenhos descreviam praticamente a necessidade de se racionalizar o consumo de água. Percebemos que nesta triangulação houve predomínio da aula de tipo reprodutivista característica chave das aulas de HEM da década de 70 e 80 . Embora a professora tenha relatado que o curso mostrou a necessidade de se trabalhar ciências na prática, percebe-se que há necessidade de um trabalho mais intensivo para que esta profissional alcance tal intento. Percebe-se que a professora deseja mudar sua prática em sala de aula, mas ainda se sente insegura. 


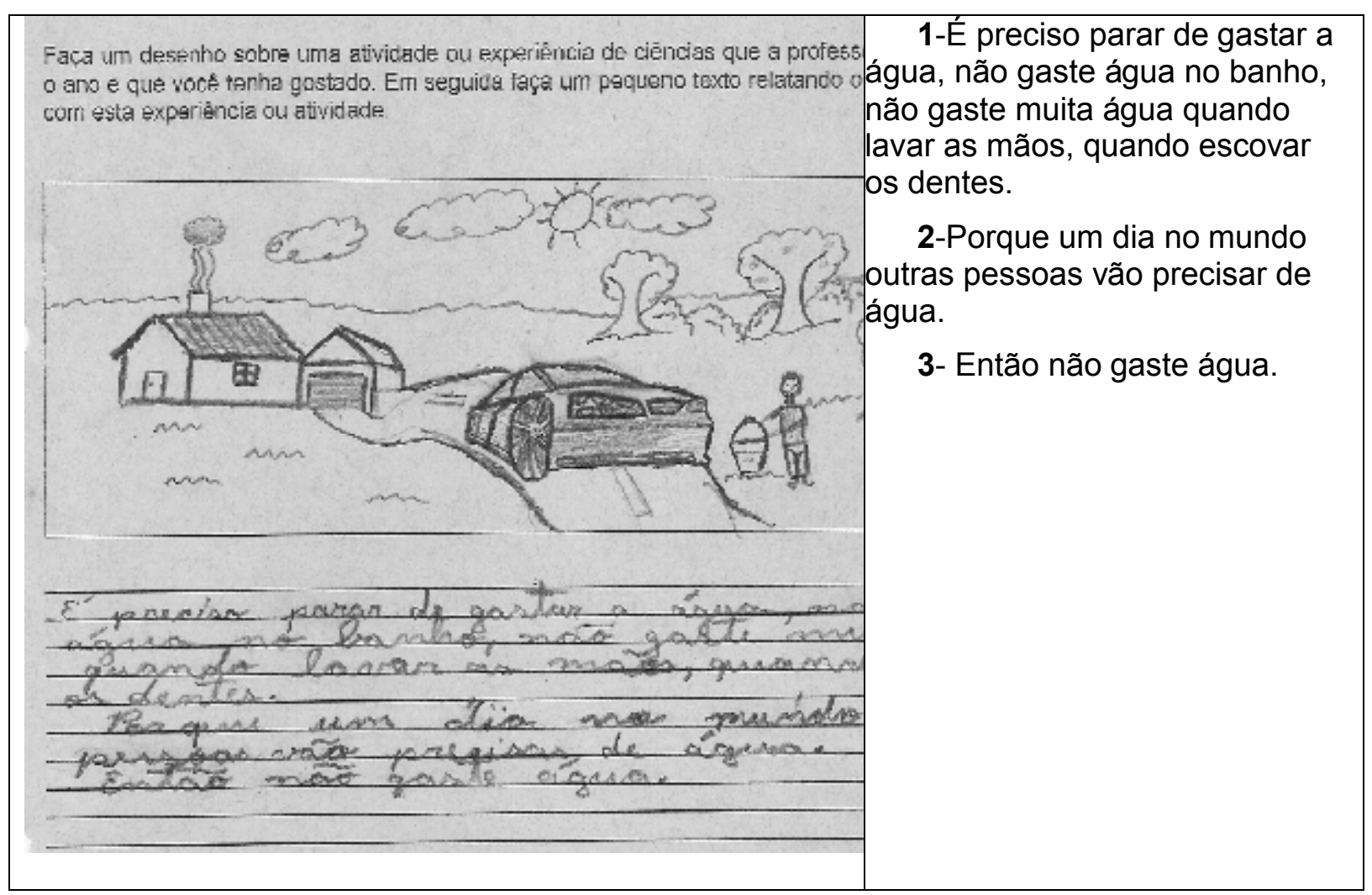

Figura 5.15: Atividade de aluno da professora E1C

As atividades dos alunos de E1C revelaram que a professora disse em entrevista que havia trabalhado bastante com o tema água, com a questão da utilização racional desse recurso natural. . Pode-se perceber que as aulas da professora E1C são monológicas em que o professor é o centro do saber e do conhecimento. Não se encontram indícios de diálogo nessas aulas. 


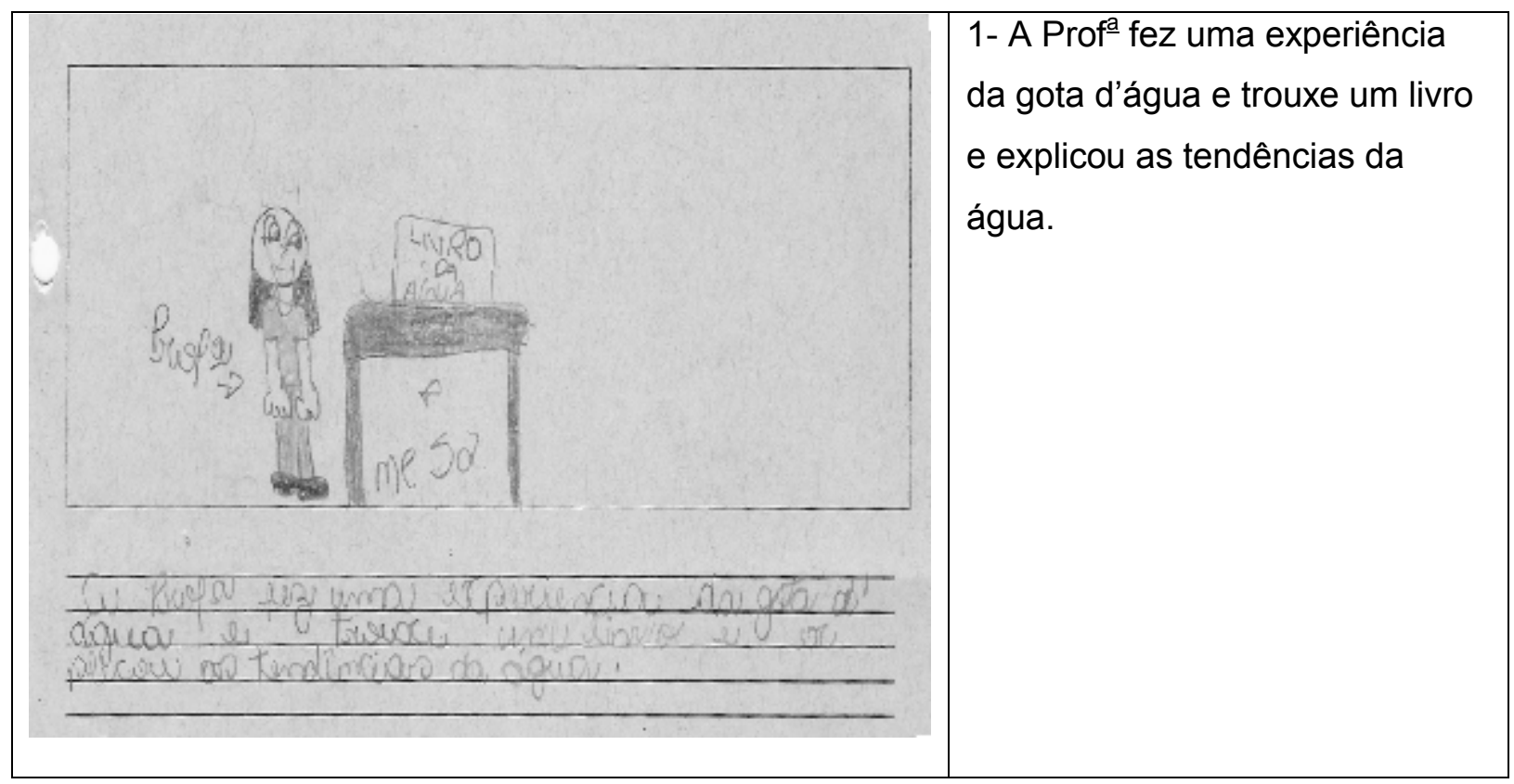

Figura 5.16: Atividade de aluno da professora E1C

A Figura 5.16 exemplifica a categoria demonstração. A criança desenhou a professora realizando o experimento. E ainda relata que a professora trouxe um livro e explicou sobre a questão da água.

Os dezenove alunos de E1D escreveram em média 7 linhas. Os temas que relataram em suas atividades foram: 5 (26\%) sobre água sendo que 01 sobre lençol freático, 01 sobre estados físicos , 01 sobre importância da água, 01 sobre ciclo da água na natureza, 01 sobre a água como geradora de energia. Dois alunos $(11 \%)$ escreveram sobre plantas sendo que 01 sobre o plantio e 01 sobre a fotossíntese. Onze alunos (58\%) escreveram sobre meio ambiente e ecologia: sendo que 05 sobre cuidados com meio ambiente, 01 sobre economia de energia, 02 sobre a interdependência entre seres vivos para sobreviver, 02 sobre crime ambiental, 01 sobre a importância do meio ambiente e do equilíbrio ecológico. Embora fossem poucos os temas trabalhados, a diversidade de sub-temas mostram que as aulas eram de boa qualidade, tal como descrita na análise curricular realizada por Miriam Krasilchik (1986). Seis textos de alunos podiam ser enquadrados em mais de uma subcategoria o que sugere que a professora faz a inter-relação de conceitos. Não houve relato de atividade experimental.

Da análise do material dos alunos, concluímos que embora a professora se utilize aula monológica e com algum teor tecnicista, esta procura trabalhar com inter-relação de conceitos meio ambiente e ecologia de forma expositiva. O material das crianças mostram claramente que não há diálogo entre a professora e os alunos e entre os alunos e seus 
pares. Os escritos dessas crianças são mais espontâneos do que das demais crianças que se inseriram na categoria não houve influência. Para essa professora o curso de formação continuada não chegou a mudar totalmente a sua prática docente, mas o trabalho com interrelação de conceitos pode ser um bom indício de que outro curso mais intensivo forneceria a segurança necessária para esta professora mudar a sua prática.

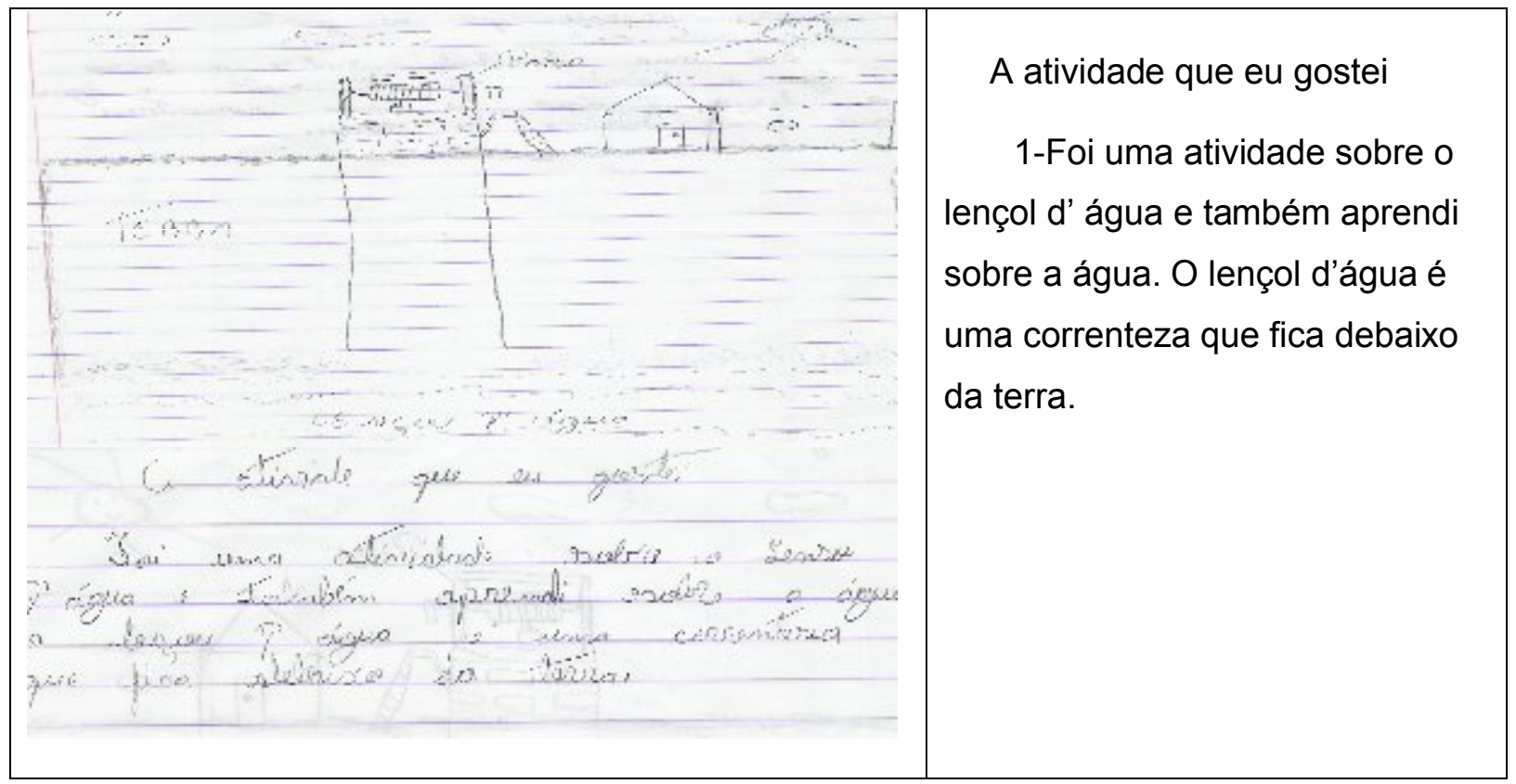

Figura 5.17: Atividade de aluno da professora E1D

Percebe-se pela escrita (Figura 5.17) que o aluno compreendeu o que vem a ser lençol freático ou lençol d'água. Na Figura 5.18, o aluno relata de uma forma geral que é preciso cuidar do meio ambiente. Questões relativas a meio ambiente e ecologia estão globalizadas. Não há escola de ensino fundamental no mundo que não tenha em seu currículo questões sobre o meio ambiente e, obviamente esse tema estaria entre os relatos colhidos.

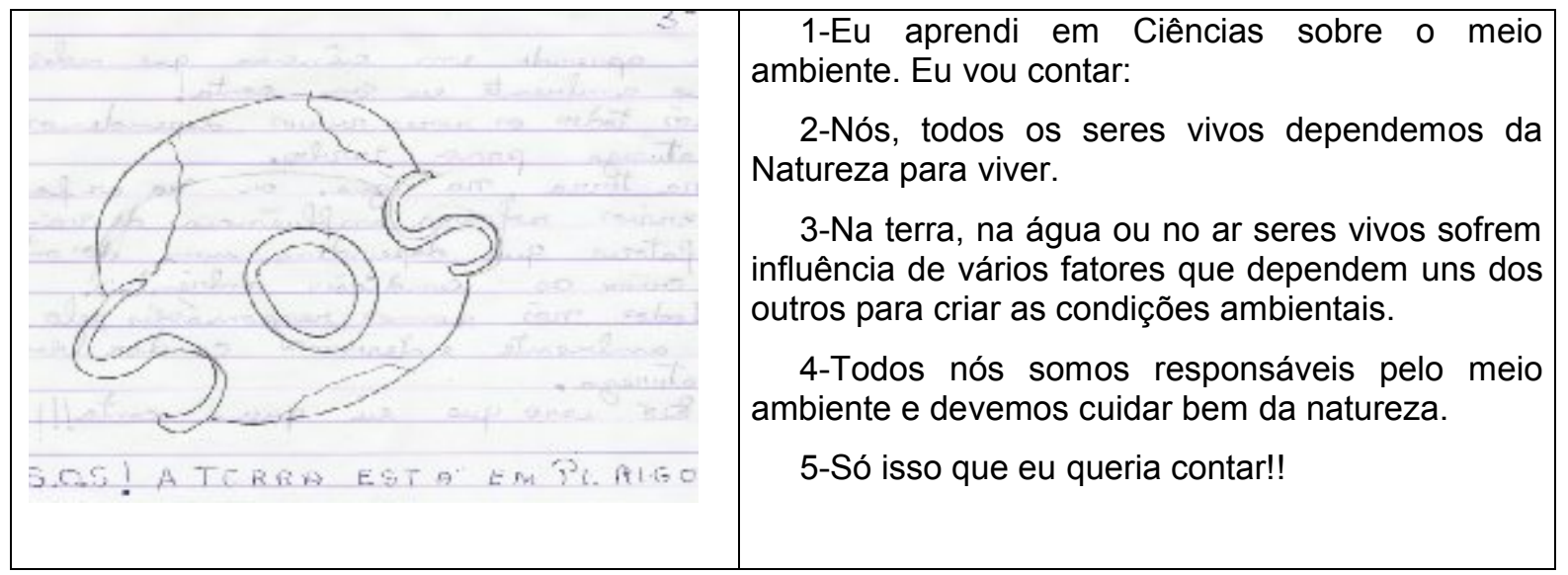

Figura 5.18: Atividade de aluno da professora E1D 
Já os dezenove alunos de E2B que são crianças da primeira série escreveram frases sobre o que eles aprenderam sobre Ciências. Algumas crianças conseguiram desenvolver textos simples conforme o ilustrado na Figura 5.19. Dos dezenove alunos de E2B, 13 escreveram sobre as plantas (68\%), 02 sobre animais (11\%) e 02 sobre a luz do sol $(11 \%)$ e 02 relataram de forma ilegível ou não compreenderam a comanda (11\%). A forma como essas crianças abordaram o tema quase que de uma maneira uniforme, permitiu verificar que não realizaram a atividade experimental conforme mencionado pela professora, pois a atividade experimental é marcante e é praticamente impossível não mencioná-la. $A$ forma como os alunos escreveram revelam que eles tiveram aula monológica que é reforçado pelo depoimento da professora. No caso desta professora, percebeu-se a mesma situação descrita por Raboni (2002): o professor entende qual é a importância da atividade prática na aula de Ciências e até propõe planos para a realização de tais atividades, mas no final, não concretiza a prática, uma situação que pode estar relacionada à insegurança, já observada em outras professoras.

A seguir um exemplo da atividade dos alunos de E2B.

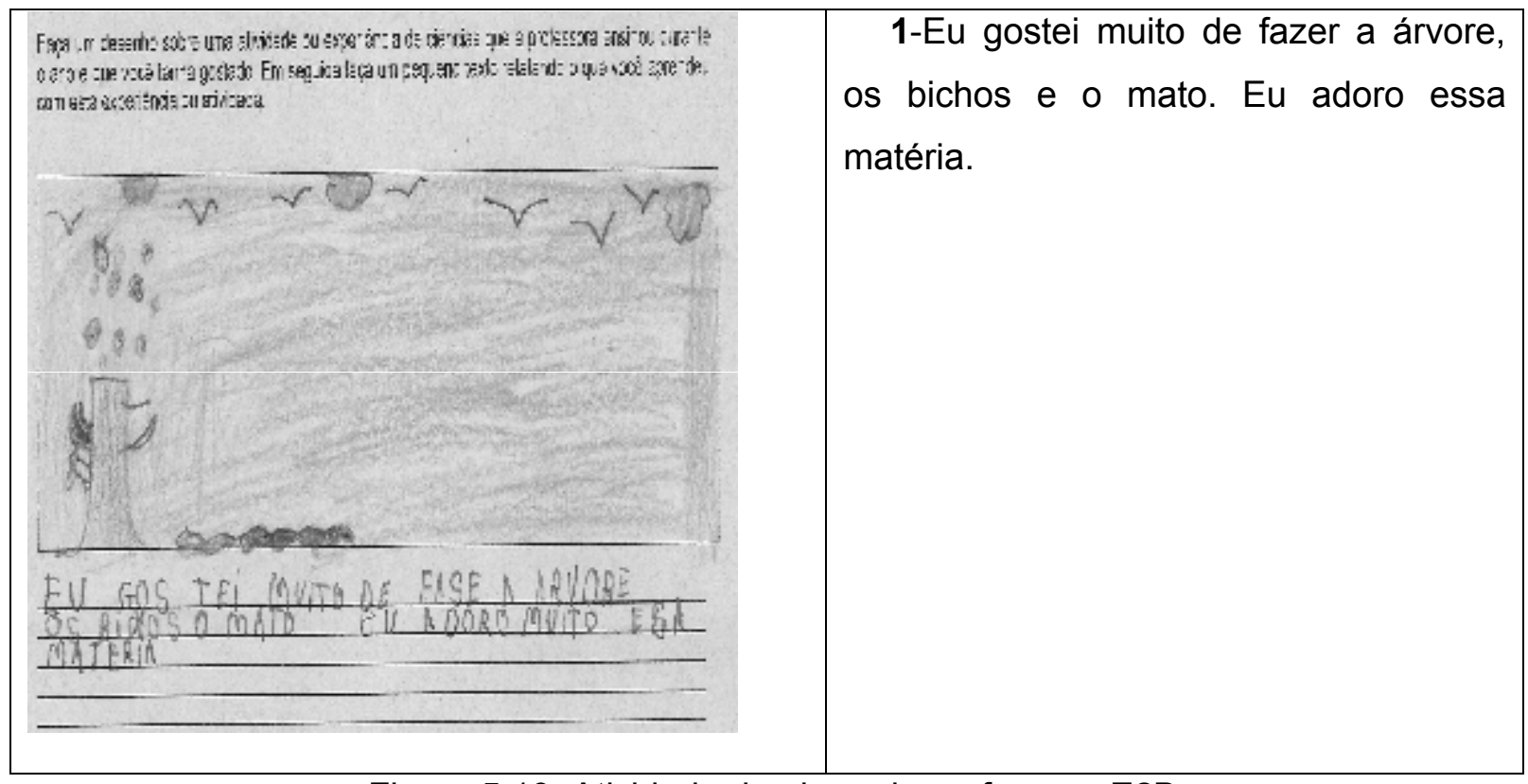

Figura 5.19: Atividade de aluno da professora E2B

Os alunos de E2C escreveram em média 5 linhas. As atividades revelaram que a professora abordou diversos temas como órgãos e sistemas do corpo humano relatado por 14 alunos (64\%), 8 alunos (36\%) fizeram referência ao meio ambiente em diversos temas como : aterro sanitário, cuidado com plantas, reciclagem, poluição e aquecimento global. 


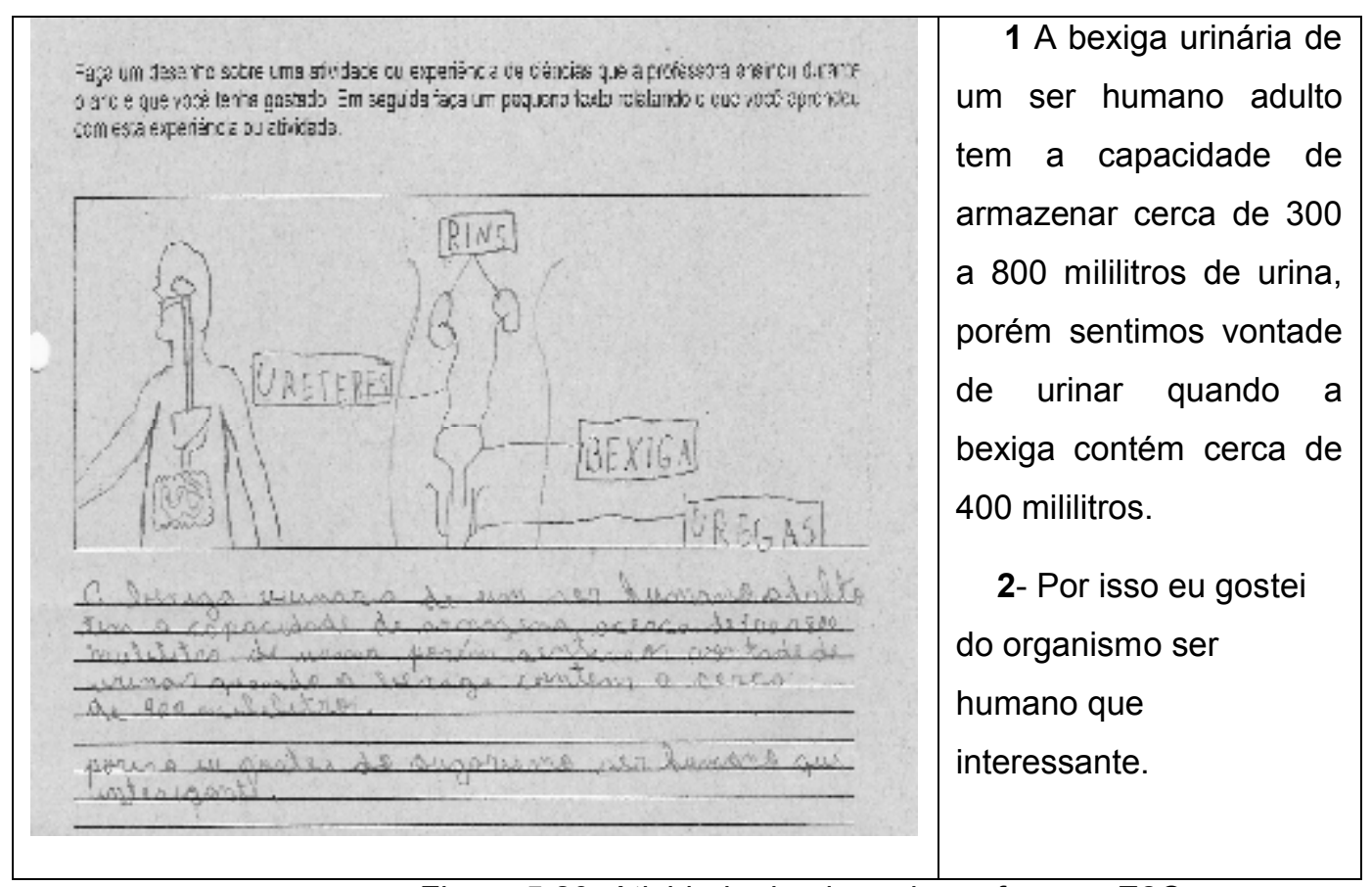

Figura 5.20: Atividade de aluno da professora E2C

Em 1 o texto foi escrito de impessoal e livresca sobre a capacidade de armazenamento da urina da bexiga. Percebe-se nesse excerto que o texto é meramente informativo não havendo indícios de que a aula foi dialógica. A Tabela 5.3, sumaria as evocações dos alunos da sub-categoria não houve referência.

Tabela 5.3: Evocações dos alunos pertencentes à categoria Não Houve Referência

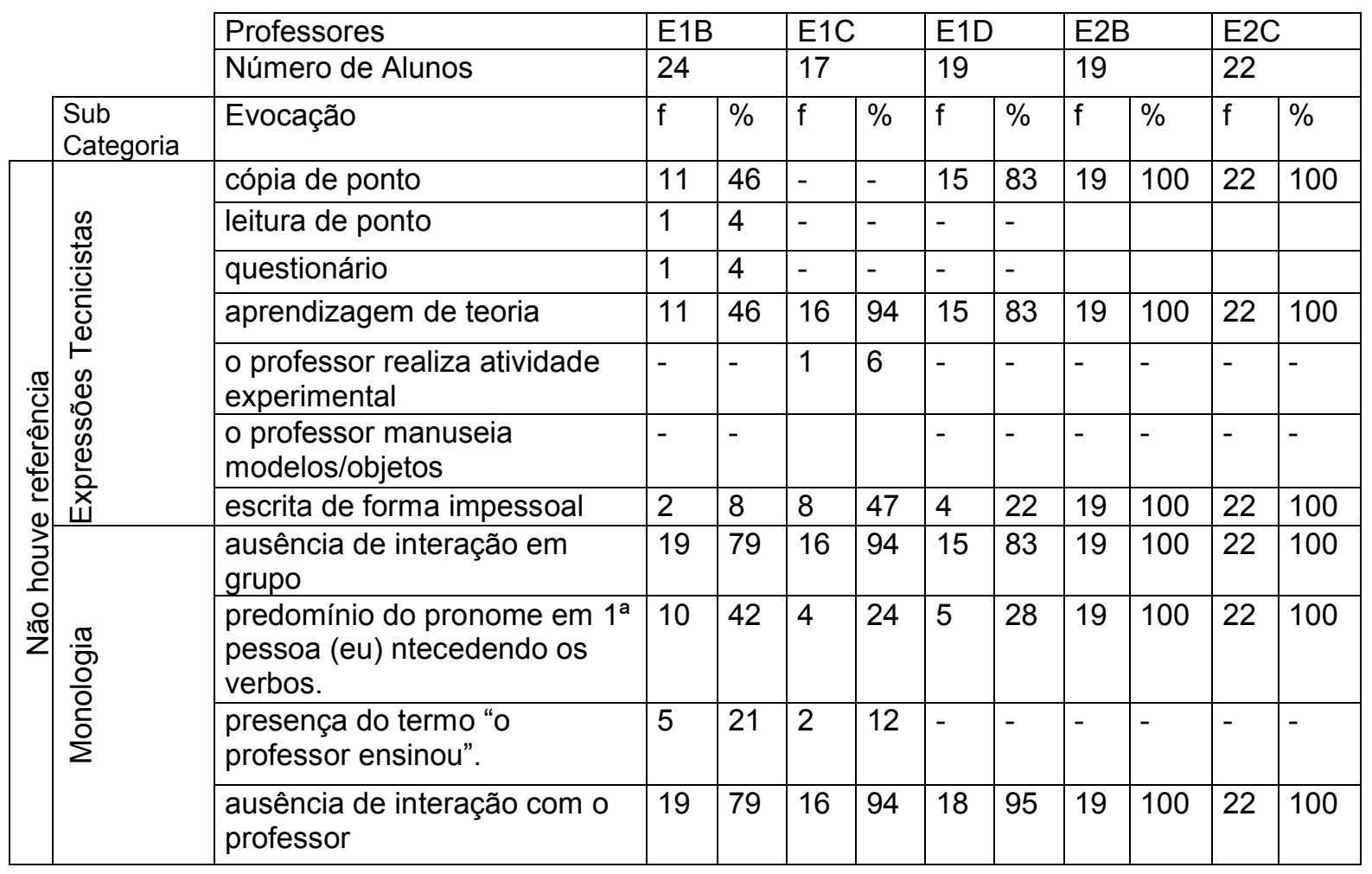




\subsection{A formação docente dos professores participantes: um passeio com Fauno nos jardins concêntricos do Reino Subterrâneo.}

Ainda foi possível, durante a entrevista fazer um levantamento do histórico da formação docente desses professores. A pesquisadora conhece bem esse histórico, pois se formou na mesma época, estudou com alguns desses professores e trabalhou por vários anos com outros. Os relatos são bem semelhantes entre os professores que fizeram parte deste estudo de caso. Pelo tempo de serviço dos entrevistados e pela idade, pode-se concluir que todos se formaram entre a entre os meados da década de 70 até final da década de 80 . Nesta época predominava as HEM que não possuíam em sua grade curricular Metodologia do Ensino de Ciências e que possuíam grandes falhas na sua estrutura curricular a ponto de ser considerada como curso de segunda categoria segundo os escritos de PIMENTA (2005) e confirmada pelos professores E1A e E2A. Com a chegada dos CEFAMS, houve alterações na grade curricular com a inclusão da disciplina Metodologia do Ensino de Ciências (KRASILCHIK, 1986), mas mesmo assim, devido ao grande número de formandos nas HEM, a alteração não atingiu os entrevistados, pois as HEM coexistiram junto com os CEFAMS por um bom tempo. A lembrança de E1B a respeito das aulas de química na HEM que segundo o relatório elaborado por KRASILCHIK (1986) para a antiga $13^{a}$ Delegacia de Ensino dizia "eram aulas que visavam a possibilidade do futuro formando prestar vestibular. As aulas decorativas, com cópia de ponto e questionário, a elaboração de material didático para aula expositiva revelam o teor tecnicista das HEM, bem lembrado por E2A em seu depoimento e tantas vezes comentado por PIMENTA (2005) e FREITAG (1986) . O foco na alfabetização lembrado pela professora E1D, a ausência de aulas práticas lembradas por E2C na sua fala pois só teve estágio de observação durante o seu curso na HEM . E por fim o relato de E2C que era uma formação que deixava a desejar também tantas vezes comentado por PIMENTA (2005)

\section{Professor E1A}

Polivalente e superficial

23-Entrevistadora: O que você pensa ou pensou daquele curso de ciências?

24-Professor E1A: Eu penso que para a gente que trabalha de primeira a quarta como PEB I, polivalente[....tem formação para trabalhar todas as disciplinas, mas não é tão profundo.

\section{Professora E2A}

244-Professora E2A: ...O professor do ensino fundamental precisa estudar muito mais, tem que saber de todas as áreas. E ciências que eu aprendi dessa forma conceitual [...] quero aprender porque eu tenho as lacunas. 
A formação "polivalente" do professor dos das séries iniciais ainda se perpetua nos cursos de Pedagogia. Na verdade o futuro profissional tem acesso a uma série de disciplinas de cunho teórico, muitas delas, até acabam repetindo o mesmo conteúdo. O futuro professor das séries iniciais acaba sendo formado para tudo e nada ao mesmo tempo. Esses cursos formam um profissional com identidade pedagógica esvaziada de conteúdo, conforme lembrado por MELLO (2000).

\section{Conteúdos de Ciências do Núcleo Comum do $2^{\circ} \mathrm{Grau}$}

\section{Professora E1B}

40-Entrevistadora: Durante o Magistério você se lembra de ter feito experiências em Ciências, de ter cursos relacionados às ciências?

41-Professora E1B: Sim. Tive Química, que eu gostava muito do jeito que o professor passava para a gente. Ele ensinava como nós deveríamos trabalhar com as crianças. Ele até fez um trabalho que até hoje me marcou. Nós tínhamos que todo mês fazer um livrinho sobre uma matéria relacionada à química. [...] E a experiência no laboratório.

42-Entrevistadora: Ah, vocês tinham laboratório?

43-Professora E1B: Tinha. Eu gostei de fazer foi detergente biodegradável e não biodegradável. Era muito interessante porque nós tínhamos que fazer e apresentar para a sala. Cada um tinha uma vez.

44-Entrevistadora: Isso era o professor de Química que fazia. Você não teve didática do ensino de ciências? Metodologia do ensino de ciências?

45-Professora E1B: Não.

Quadro 5.17: Referente à sub-categorias de formação docente

Os conteúdos relativos à Ciências que estes professores tiveram eram relacionados ao núcleo comum do antigo $2^{0}$ Grau. Não tiveram acesso à aulas práticas de Ciências e muito menos didática e metodologia específica. Esse resultado está de acordo com a crítica de por DELIZOICOV \& ANGOTTI (1991):

O tratamento metodológico do ensino-aprendizagem das Ciências Naturais tem sido tão inconsistente, precário e frágil que nem mesmo há uma nomenclatura homogênea para a disciplina [...] ou ainda é associada a subtítulos como Programas de Saúde e Ecologia. Esses desencontros, aliados a outras razões [..] evidenciam um trabalho não-sistemático e pouco crítico de capacitação efetiva dos professorandos para desenvolverem a formação inicial das crianças em Ciências

No Quadro seguinte veremos um caso de aula expositiva e não dialógica onde predominou a preocupação em desenhar um cartaz sobre plantas: 


\section{Aula expositiva com cartaz didático sobre plantas}

\section{Professora E1C}

100-Pesquisadora: Durante o magistério, quando você estava fazendo magistério, Você teve aula prática de ciências? Você teve Metodologia de Ensino de Ciências, você teve Didática?

101-Professora E1C: No último ano de Magistério eu tive aula prática nas escolas. Foram quarenta dias de estágio. Nesses quarenta dias a gente não ia para a escola, a gente preparava aula e ia pro colégio mesmo. Depois desses quarenta dias é que você voltava a ter aula.

102- Pesquisadora: E nesses quarenta dias você chegou a ter aula prática de ciências? Chegou a dar aula prática de ciências?

103- Professora E1C: Eu cheguei a fazer um trabalho que para mim era muito especial. Era a minha primeira formatura e eu estudava num colégio particular [...] era uma honra eu apresentar naquela escola um bom trabalho aos alunos. [..] Eu fiz um desenho da parte de ciências acho que sobre plantas. A professora de Didática assistindo a aula disse para mim. "Este é um cartaz digno de ser apresentado."

Quadro 5.18: Referente à sub-categorias de formação docente

Pode-se notar aqui a precariedade do estágio supervisionado em que o futuro professor era lançado. O "preparo" desta aula expositiva sobre plantas, a preocupação com o cartaz e não se de fato os alunos iriam aprender algo evidenciam as lacunas desta formação. O estágio supervisionado na formação docente segundo Pimenta envolve "saber observar, descrever, registrar, interpretar e problematizar e, conseqüentemente, propor alternativas de intervenção" (PIMENTA, 2001, p. 76), fato que não ocorreu com a professora E1C.

A formação voltada para a alfabetização é relatado pela professora E1D (Quadro 5.19), um problema histórico.

\section{Foco na alfabetização}

\section{Professora E1D}

127-Entrevistadora: Não teve didática em ensino de ciências, nem metodologia em ensino de ciências?

128- Professora E1D: Não. O meu era voltado para alfabetização, era formação mesmo. Quando você ia fazer o estágio, tinha três professores para observar a regência, que ficavam no fundo da sala assistindo a tua regência.

\section{Quadro 5.19: Referente à sub-categorias de formação docente}

No Quadro seguinte o relato da professora acerca das aulas de Ciências em que se fazia leitura de textos e aplicação de questionários para estudo e como esta prática produziu reflexos em sua prática docente. 


\section{Aulas decorativas com ponto e questionário}

\section{Professora E2A}

182-Entrevistadora:Em relação ao ensino de ciências, quando você fez o Magistério, teve aulas práticas de ciências?

183- Professora E2A: Não puramente decorativa. Era a época do ensino por questionários, né.? Tinha lá o ponto como a gente falava e não se observava[...]Não tinha nada prático [...]

184-Entrevistadora: Isso teve algum conseqüência de ensinar ciências para as crianças?

185-Professor E2A: [...] incomodava ser repetitiva[...] teve repercussão sim. No começo era copiar também. Depois que eu fui refletindo e eu mudei de postura [...]. Ficava sempre em segundo plano ciências assim, né? Eu reproduzia a forma de ensinar como eu aprendi porque o livro era igual como e aprendi. [...]Então retransmitia como me transmitiram.

Quadro 5.20: Referente à sub-categorias de formação docente

A ausência de Metodologia e Didática específica é lembrada por E2B. As falhas na formação inicial é amplamente debatida por PIMENTA $(2001,2005)$ e DELIZOICOV \& ANGOTTI (1991).

\section{Ausência de prática \\ Professora E2B}

333-Entrevistadora: Durante o seu curso de magistério, você fez algum curso ligado à metodologia do ensino de ciências?

334- Professora E2B :: Não ligado diretamente a ciências, não. Eu tive metodologia mas não ligado à ciências. Você só tem teoria no magistério. Você não vê prática. É chegar jogar o conteúdo e acabou. A gente sofre quando pega a sala de aula.

Quadro 5.21: Referente à sub-categorias de formação docente

A professora E2C relata as falhas da sua formação inicial a ausência da especificidade também Ihe traz insegurança. Tal problema já foi abordado por vários autores como Bızzo (1995), PImentA (2001,2003), Delizolcov \& ANGotTI (1991). O Quadro 5.17 apresenta o relato desta professora que foi inserido na subcategoria Formação que deixa a desejar.

\section{Formação que deixa a desejar}

Professora E2C

293- Professora E2C: Não . É realmente uma coisa que deixa a desejar. Ainda quando eu fiz, há vinte e sete anos atrás não tinha nada específico.

294-Entrevistadora: E isso faz falta para você em algum momento?
} 
295-Professor C: Ah sim. Porque se você tiver uma capacitação bem mais elaborada, você tem segurança para trabalhar [...]. Aí de repente você tem medo de acontecer alguma coisa.... eu acho que realmente é muito proveitoso sim. As experiências que eu tive nessa parte foi com você.

Quadro 5.22: Referente à sub-categorias de formação docente

A formação continuada desses professores se dá por auto formação conforme exposto por E2A e E1C e E1D: a leitura de livros, jornais e revistas. E1D procura fazer cursos por conta própria e lembrou-se de um curso de formação continuada em ciências feito em 1994 ou 1995, ou seja, há 13 anos atrás. Os cursos de formação continuada oferecidos pela Secretaria da Educação reforçam a precária formação desses professores ao enfatizar quase que exclusivamente a alfabetização. As perguntas não deixam de surgir na mente desta mestranda: não se alfabetiza através do ensino de Ciências, Matemática, História e Geografia? O que é estar letrado? Por acaso não é saber interpretar os infinitos textos que as áreas do conhecimento podem nos oferecer? Pode uma criança sair do Fundamental I e ir para o Fundamental II sem noções básicas de Ciências, História e Geografia? Que cidadão estamos formando?

Leitura de livros

Auto Formação

\section{Professora E2A}

\section{8-Entrevistadora: Foram somente leituras?}

189-Professora E2A: Foram leituras de paradidáticos que eu fui procurando [...]. Fui relacionando conteúdo do livro didático com esses livros que eu tinha lido e cumprindo as experiências. Foi mais pesquisa, mas fui eu mesma. Não foi curso. Nunca fiz curso voltado para ciências pelo Estado. Nunca fiz.

Professora E1C

106-Entrevistadora: E nesses 20 anos que você leciona, você teve algum curso de Ciências?

107- Professora E1C: Não. Ciências eu nunca tive nenhum curso. Mas todos os dias, eu leio jornal e livros que fundamentam. [...] procuro fazer pesquisa, procuro olhar.

Quadro 5.23: Referente à sub-categoria formação continuada

Esses profissionais em sua maioria se aposentarão com trinta anos de exercício docente e no caso os mais jovens quando tiverem mais que 54 anos de idade se forem mulheres e 60 anos se forem homens. Isto significa que estarão trabalhando mais 17 anos até se aposentarem. Cursos de formação continuada aplicados em horário de serviço e de forma mais intensiva podem produzir uma melhora do desempenho desses professores. Conforme bem lembrado por Pardal \& Martins, (2005) em Portugal, a formação continuada já é um direito do professor (Quadro 5.24). 


\section{Cursos Promovidos pela Secretaria de Estado da Educação} Cursos Promovidos por Entidades Particulares

\section{Professora E2A}

\section{4-Entrevistadora:Nunca teve nesses vinte anos de magistério?}

205- Professora E2A: Não. Eu tive cursos voltados para Português, Produção de Textos, Matemática...mas para área de Ciências não tive.

\section{6-Entrevistadora: Esses cursos nunca chegaram para você?}

207- Professora E2A: Como é que eles chamam esses cursos. É para você ir lá e ser.um multiplicador. Não, teve um. Sobre o Procel. Eu lembro que fui à Leste. Era sobre economia de energia naquela época do apagão. Então o governo tava lá para ensinar você como economizar energia. Esse do PROCEL, mas foi uma coisa bem vaga de umas horinhas.

\section{Professora E1D}

129-Entrevistadora: Em algum momento você sentiu falta de não ter um curso mais voltado para ciências?

130- Professora E1D: Eu senti não só falta de uma orientação não só em ciências mas também em história e geografia [..]. Eu não fiz cursos de Ciências para eu poder trabalhar. Então eu faço articulação com as disciplinas.

131-Entrevistadora: Esses cursos de Ciências que você fez foi promovido pela Rede Estadual de Ensino?

132- Professora E1D: Esses cursos foram promovidos pela Rede Estadual de Ensino e pela Folha de São Paulo.

133-Entrevistadora: Faz muito tempo?

134- Professora E1D: O da Folha de São Paulo foi em 87.

\section{5-Entrevistadora: E esse do Estado em Ciências?}

136- Professora E1D: Esse do Estado foi em 95...94 ou 95. Quando era, quando era a décima terceira delegacia [...] Eu me lembro que nós fizemos até umas experiências do ar, sabe. De como funcionava e como era composto o ar. Foi muito bom.

\section{9-Entrevistadora: Foi só aquilo.}

140- Professora E1D: Foi só aquilo. Ciências na escola, você que devia de dar conta,né? Eu não sei muita coisa, a gente sabe na prática, o dia a dia. A gente procura sempre estar se aprimorando, né Mari Inez. Mas que a gente recebe informação e orientação não. É mais de alfabetização. O Letra e vida por exemplo.

\section{1-Entrevistadora: No Letra e Vida não aparece nada relacionado a ciências?}

142-Professora E1D: Não. Só relacionado a alfabetização mesmo [...] Não tinha nada que me empolgasse, não. Ciências é muito difícil. Ciências, História e Geografia eles só fazem curso para os professores de quinta em diante. Para o PEB I de primeira a quarta é muito difícil. Você fica só com a teoria. Agora a única orientação que eu tive foi naqueles HTPCs que você deu. Experiência concreta 
Capítulo 6:

Conclusões 


\subsection{Comentários}

Neste estudo de caso ficou evidenciado que dois professores, uma da escola E1 (Professora 1) e uma da escola E2 (E2A) foram influenciadas pelo curso a ponto de utilizarem mapas conceituais em sala de aula, caracterizando uma prática docente mais dialógica em relação aos alunos. Os professores E1A e E2A sentiram-se encorajados a utilizarem atividades experimentais em sala de aula e conseqüentemente a trabalharem de forma dialógica com os seus alunos. No caso da professora E2A o curso auxiliou a consolidar o uso de atividades práticas em sala de aula. Os alunos desses professores ao redigirem sobre a atividade que mais gostaram em Ciências, durante o ano letivo, a fizeram de forma mais coerente e coesa do que as crianças que estavam sob a regência dos professores que não foram influenciados pelo curso. Uma prova de que o pensar sobre a observação fenômeno pode colaborar amplamente para o desenvolvimento da língua e do raciocínio lógico. O ensino de Ciências para crianças nas séries iniciais, quando acompanhado de atividades práticas auxiliam a desenvolver a capacidade de leitura e escrita e ordenação de causas e conseqüências. Habilidades que posteriormente a ajudarão a resolver situações problema. Desde Vigostsky já se sabe que a criança na faixa etária atendida pelas séries iniciais do Ensino Fundamental conseguem aprender melhor através da manipulação de objetos diversos, e através da realização de atividades em grupos que possibilitem dialogar uns com os outros, como no caso da realização de atividades experimentais. Uma oposição aos projetos vigentes na Secretaria de Estado de Educação de São Paulo que têm como pedra de toque apenas o ensino da Língua Portuguesa e Matemática nos currículos de primeira e segunda série do primeiro ciclo do Ensino Fundamental, destinando-se o ensino de Ciências para crianças à apenas a interpretação de alguns textos informativos.

Quanto às professoras que não foram influenciadas pelo curso, não nos surpreendeu a professora E2B ter chegado até a propor atividades experimentais para a série em que regia as suas aulas e no fim não tê-las posto em prática, provavelmente por insegurança, fato amplamente comentado nesta Dissertação tendo por base os autores Raboni (2002) e Bizzo (2005). Não podemos também de deixar de comentar que as demais professoras não influenciadas pelo curso estavam muito vinculadas à pratica docente de sua formação inicial, algo que ficou bem transparecido nas entrevistas. Não há como negar que as marcas produzidas pela HEM como a supervalorização da alfabetização e do ensino de matemática em detrimento das demais disciplinas e da insegurança gerada dessa formação inicial incoerente com a grade curricular do nível de ensino que iriam atuar. Marcas tão profundas que nem uma posterior formação em universidades conseguiram apagar.

Neste trabalho ficou constatado um curso de formação continuada de base construtivista pode auxiliar os professores a refletirem e auxiliá-los na construção da autonomia profissional docente 
conforme abordado por Jué (2007), Krasilchik \& Cunha (2007), Taylor e Coll (2002) e Paquay (2001). Esses cursos devem ser intensivos, devem ter carga horária de no mínimo duas horas por encontro e o intervalo entre um encontro e outro não pode ser superior a uma semana para se evitar que os participantes se dispersem.

Por um outro lado, cursos intensivos podem ajudar os docentes que resistem quanto à mudança de sua prática em Ciências a dominar sua insegurança inicial em ministrar aulas dialógicas. Fica evidente que o curso de formação continuada deve ter a metodologia que se deseja que o docente empregue em suas aulas.

\subsection{Perspectivas}

Este estudo de caso pode colaborar com o planejamento de outras ações de formação continuada em Ciências para professores da séries iniciais, pois delineou as influências de um curso desde o momento em que os professores começaram a freqüentar até o impacto na sala de aula. Esta investigação pode colaborar com planejamento e organização de futuras ações de formação continuada em Ciências para professores das séries iniciais que objetivem a reflexão e a autonomia do professor quanto ao preparo de suas aulas.

Esperamos que este trabalho tenha demonstrado que com emprego de metodologia adequada, o ensino de Ciências para crianças não é um tabu e que pode auxiliá-la professores e alunos no discernimento de causas e conseqüências.

E por fim esperamos que este estudo de caso possa auxiliar os setores responsáveis pelas Secretarias de Estado da Educação a voltarem o olhar para a questão do ensino de Ciências nas séries iniciais, pois como foi comentado ao longo desta Dissertação, a História mostra que países que possuem melhor qualidade de ensino não descartam este currículo nas séries iniciais da educação básica. 


\section{BIBLIOGRAFIA}

ABC Academia Brasileira de Ciências. Projeto Mão na Massa. http://www.abc.org.br/article.php3?id_article=490 Acesso em 10/01/2009.

AKERSON, V. L.FLICK, L.B.;LEDERMAN N.G.;The influence of primary children's ideas in science on teaching practice. Journal of Research in Science Teaching vol. 37, nº. 4,p. 363-385. 2000.

ALARCÃO, M.I. Professores reflexivos em uma escola reflexiva. 1a ed São Paulo: Cortez , 2003.102p.

ALFONSO, A.J.L. Contributo para uma Formação Contínua Centrada nas Necessidades dos Professores do $1 .^{\circ}$ Ciclo do Ensino Básico na Àrea de Ciências da Natureza, 2005. 233p. Dissertação de Mestrado em Supervisão Pedagógica em Ensino de Ciências - Instituto de Educação e Psicologia, Universidade do Minho, Braga,2005.

Almeida, L. \& Freire, T. (1997). Metodologia da Investigação em Psicologia da Educação. Coimbra: APPORT - Associação dos Psicólogos Portugueses apud ALFONSO, A.J.L. Contributo para uma Formação Contínua Centrada nas Necessidades dos Professores do $1 .^{\circ}$ Ciclo do Ensino Básico na Àrea de Ciências da Natureza, 2005. 233p. Dissertação de Mestrado em Supervisão Pedagógica em Ensino de Ciências - Instituto de Educação e Psicologia, Universidade do Minho, Braga,2005.

AMARAL, Ivan Amorosino do. Currículo de Ciências: das tendências clássicas aos movimentos atuais de renovação. In: BARRETO, B. Siqueira de Sá (Org.). Os currículos do Ensino Fundamental para as escolas brasileiras. São Paulo:Autores Associados, 1998, p.201-232 apud LACANALLO, L.F. O Processo De Mudança Conceitual no Ensino de Ciências Naturais na Perspectiva dos Professores das Séries Iniciais do Ensino Fundamental. 2005. 126 folhas. Dissertação (Mestrado em Educação -Área de Concentração: Aprendizagem e Ação Docente) Maringá, 2005.

ARROIO,A.; HONÓRIO K. M., Weber C. K., HOMEM-DE-MELLO P., GAMBARDELLA, M. T.P.;SILVA, A. B. F. o Show da Química: Motivando o Interesse Científico. Quim. Nova, Vol. 29, No. 1, 173178, 2006.

AUSUBEL, D. P.; NOVAK, J. D.; e HANESIAN, H. Psicologia educacional.Tradução de Eva Nick et al. Rio de Janeiro, Interamericana, 1980. Tradução de Educational psychology, New York: Holt, Rinehart and Winston, 1978

BARDIN,L. Análise de Conteúdo.3 ed. Lisboa,2004

BARREIRO,A.C.M.; BAGNATO,V. Aulas Demonstrativas nos Cursos de Física. Cadernos.Catarinenses de Ensino de Física, Florianópolis, v.9,n.3: p.238-244, dez.1992. 
BARROS, G. et al. Hacia la innovación de las actividades Prácticas desde la formación Del Profesorado. Enseñanza de las Ciencias: Revista De Investigación Y Experiencias Didácticas. Barcelona, Volume 16, Fascículo 2 Páginas 353-366, publicação semestral,1998.

BARTH, B.M. O saber em construção. Instituto Piaget, Lisboa,1993 apud BRAGA, A. Os Saberes de Professores que Ensinam Ciências nas Séries Iniciais- Um estudo de caso. Dissertação de Mestrado, São Carlos: UFSCAR, 2005. 146p.

BELTRAN M.H.R; BELTRAN, N.O.; SCHNETZELER, R.P; MARCONDES, M.E.R.; ROMANELLI, L.I.; REZENDE, D.B.;MASON, A.B. PROQUIM - Projeto de Ensino de Química para o $2^{\circ}$ Grau. São Paulo: Universidade Estadual de Campinas, 1986. 52p.

BIZZO, N. Metodologia e prática de ensino de ciências: A aproximação do estudante de magistério das aulas de ciências no $1^{\circ}$ grau 1995 . Disponível em http://www.ufpa.br/eduquim/praticadeensino.htm Acesso em: 11/07/2006.

BLOOM,B.; ENGELHART, M.D.; FURST E. J.; HILL, W.H.; KRATHWOHL, D. R. Taxionomia de objetivos educacionais; domínio cognitivo . Tradução de Flávia Maria Sant'Anna. Porto Alegre, Globo, 1973. 180p.

BONIL, J., La aventura de integrar la complejidad en la educación científica de la ciudadanía. Enseñanza de las Ciencias: Revista De Investigación Y Experiencias Didácticas. Barcelona, Número Extra, VII Congresso Páginas 1-4, publicação semestral,2005.

BONIL, J. y PUJOL, R. M: El paradigma de la complexitat, una aproximació des de l'àrea de didàctica de les ciències. treball de recerca presentat en el marc del programa de Doctorat de Didàctica de les Matemàtiques i de lês Ciències Experimentals.U.A.B (Document no publicat). Bellaterra: Universitat Autònoma de Barcelona, 2003. apud BONIL, J., La Aventura de Integrar la Complejidad en la Educación Científica de la Ciudadanía. Enseñanza De Las Ciencias: Revista De Investigación Y Experiencias Didácticas. Barcelona, Número Extra, VII Congresso Páginas 1-4, publicação semestral,2005.

BORGES, C.M.F. Saberes docentes: diferentes tipologias e classificações de um campo de pesquisa. Educação \& Sociedade. Ano XXII, no 74, Abril/2001, p. 59-76 apud BRAGA, A. Os Saberes de Professores que Ensinam Ciências nas Séries Iniciais- Um estudo de caso. Dissertação de Mestrado, São Carlos: UFSCAR, 2005. 146p.

BORGES DA SILVA, A.M. Utilização de Sensores no $1^{\circ}$ Ciclo do Ensino Básico - Aprendizagem de Alunos e Desenvolvimento Profissional de Professores. 2004, 174p. Dissertação de Mestrado em Supervisão Pedagógica em Ensino de Ciências - Instituto de Educação e Psicologia, Universidade do Minho, Braga,2004. 
BORTOLAI, M. M.S.; REZENDE, D.B. ; TAVARES, M. I. Alteração do conceito de transformação em aulas de Química. In: IV EPPEQ - ENCONTRO PAULISTA DE PESQUISA EM ENSINO DE QUÍMICA, 2007, São Paulo. IV EPPEQ - Encontro Paulista de Pesquisa em Ensino de Química: A Formação do Pesquisador. São Paulo : IQUSP/FEUSP, 2007. p. 40-40.

BRAGA, A. Os Saberes de Professores que Ensinam Ciências nas Séries Iniciais- Um estudo de caso. Dissertação de Mestrado, São Carlos: UFSCAR, 2005. 146p.

BRANDI, A.T.E.; GURGEL, C.M.A. A alfabetização científica e o processo de ler e escrever em séries iniciais: emergências de um estudo de investigação-ação. Ciência \& Educação, v.8, n.1, p.113 125, 2002.

BRASIL, Parâmetros Curriculares Nacionais: Ciências. Brasília: Secretaria de Educação Fundamental, 1997.128p.

CALVO, C.V. El Profesor de Educación Primaria: Una Propuesta de Formación Inicial Desde la Perspectiva de la Didáctica de las Ciencias Experimentales. 1994/1995.213folhas. Tese de Doutorado em Humanidades Y Ciências Sociais. Universidad de La Laguna. Laguna, 1994/1995.

CAMPOS,H. A operação do texto. São Paulo: Perspectiva, 1976. "operação radical de tradução" São Paulo: Perspectiva, 1981.

CAPECCHI, M. C. V. M.; CARVALHO, A. M. P. Argumentação numa aula de conhecimento físico com crianças na faixa de oito a dez anos. Investigações em Ensino de Ciências (UFRGS), Porto Alegre, Brasil, v. 5, n. 3, p. 171-189, 2000.

CARNEIRO, M.H.S.; SANTOS, W.L.P.;MÓL,G.S.Livro didático inovador e professores: uma tensão a ser vencida. Ensaio:Pesquisa e Educação em Ciências. Volume 7, número 2, dez 2005. http://www.portal.fae.ufmg.br/seer/index.php/ensaio.Acesso em 26/04/2009

CARVALHO, R. História do Ensino em Portugal: Desde a Fundação da Nacionalidade até o Fim do Regime de Salazar-Caetano. Lisboa: Fundação Calouste Gulbenkian, 2001.

Cohen, L. \& Manion, L. (1990). Métodos de investigación educativa. Madrid: Editorial La Muralla, S. A APUD ALFONSO, A.J.L. Contributo para uma Formação Contínua Centrada nas Necessidades dos Professores do $1 .^{\circ}$ Ciclo do Ensino Básico na Àrea de Ciências da Natureza, 2005.233p. Dissertação de Mestrado em Supervisão Pedagógica em Ensino de Ciências - Instituto de Educação e Psicologia, Universidade do Minho, Braga,2005.

CONDE, M.T.B. O modo de ensino mútuo na formação dos mestres de primeiras letras. uma experiência pedagógica no portugal oitocentista. Revista Lusófona de Educação, $\mathrm{n}^{\circ}$ - 6 . Universidade Lusófona de Humanidades e Tecnologias. Lisboa Portugal, p 117-137. 
CUNHA, A.M.O. A Mudança Conceitual de Professores num Contexto de Educação Continuada. 479 folhas. Tese (Doutorado), Faculdade de Educação, Universidade de São Paulo, 1999.

.; KRASILCHIK, M.A Formação Continuada de Professores de Ciências: Percepções

a Partir de uma Experiência [online] Disponível na internet via WWW URL: http://www.educacaoonline.pro.br/a formacao continuada.asp Capturado em 21/09/2005

CUNHA, Luiz Antônio. A universidade temporã. 2.ed. Rio de Janeiro: Francisco Alves, 1986 apud ZOTTI, S. A. Organização do ensino primário no Brasil: uma leitura da história do currículo oficial. in: navegando pela história da educação brasileira. Org: José Claudinei Lombardi, Demerval Saviani e Maria Isabel Moura Nascimento, Campinas, São Paulo, HISTDBR, 2006, 1 CD- ROM. Fóton-Midia, 2006.

DANTAS, C.R., Concepções sobre a digestão/excreção em alunos, professores e futuros professores do Ensino Básico. 2005.135 p. Mestrado em Estudos da Criança Promoção da Saúde e do Meio Ambiente-Instituto de Estudos da Criança, Universidade do Minho, Minho, 2006.

DIAS, R.; LOPES, A. C. Competências na formação de professores no Brasil: o que (não) há de novo. Educação e Sociedade, Campinas, v. 24, n. 85, p. 1155-1177, 2003

EVANGELISTA, O. Formar o mestre na universidade: a experiência paulista nos anos de 1930. Educação e Pesquisa, São Paulo, volume 27, número 2, páginas 247-259,publicação semestral, jul./dez. 2001.

EURYDICE. O ensino das Ciências nas escolas da Europa: Políticas e investigação.2006,103p.

FREITAG, B. Escola estado e sociedade. São Paulo: Editora Moraes,1986.142p

Gallagher, J. J. (2000). Advancing our knowledge in order to achieve reform in science education. Journal of Research in Science Teaching, 37(6), 509-51. apud HUDSON, P. B.; MC ROBBIE, C. J. Evaluating a specific mentoring intervention for preservice teachers of primary science. In proceedings International Education Research Conference -AARE - NZARE, Auckland, New Zealand(2003).

GALIAZZI, M. C. ; MORAES, R. Educação pela pesquisa como modo tempo e espaço de qualificação da formação de professores de Ciências. Ciência e Educação (UNESP), Bauru, v. 8, n. 2, p. 237-252, 2002.

GAUTHIER, C. MARTINEAU, S. DESBIENS, J.F.SIMARD, D. Por uma teoria da pedagogia pesquisa contemporânea sobre o saber docente. Editora UNIJUÍ, Ijuí, 1998 apud BRAGA, A. Os Saberes de Professores que Ensinam Ciências nas Séries Iniciais- Um estudo de caso. Dissertação de Mestrado, São Carlos: UFSCAR, 2005. 146p. 
GATTI, B. A. Formação de professores e carreira : problemas e movimentos de renovação. 2. ed. - Campinas, SP : Autores Associados, 2000.

GHIRALDELLI JR., Paulo. Filosofia e História da Educação Brasileira. São Paulo: Editora Manole, 2003.

GINZBURG, Carlo. Mitos, emblemas, sinais: morfologia e história. Tradução por Federico Carotti. São Paulo: Companhia das Letras. 1989. 281p apud RABONI, P.C. Atividades Práticas de Ciências Naturais na Formação de Professores para as Séries Iniciais. 2002. 163 folhas. Tese de Doutorado. Faculdade de Educação, Universidade Estadual de Campinas, Campinas, 2002.

GUIDO, L.F. E. A Evolução Conceitual na Prática Pedagógica do Professor de Ciências das Séries Iniciais. Campinas: Unicamp, 1996. 195p. Mestrado em Metodologia do Ensino. Faculdade de Educação, Universidade de Campinas, Campinas,1996,

HUDSON, P. B.; MC ROBBIE, C. J. Evaluating a specific mentoring intervention for preservice teachers of primary science. In PROCEEDINGS INTERNATIONAL EDUCATION RESEARCH CONFERENCE -AARE - NZARE, Auckland, New Zealand(2003)

Hudson, P \& Skamp, K, 'Mentoring preservice teachers of primary science', The Electronic Journal of Science Education, vol. 7, no. 1. 2002

IMESP. Lei 5692/71 de 11 de agosto de 1971. Lei de Diretrizes e Bases da Educação Nacional. Acompanham Leis e Decretos Federais e Estaduais, Pareceres, Deliberações e Resoluções dos Conselhos Federal e Estadual de Educação, 1979. 280p

JONES, M.M. Collaborative partnerships: a model for science teacher education and professional development , Australian Journal of Teacher Education ,Vol 33, 3, June 2008,p.61.

KEMPA, R. F. Studies in Science Education 1976, 3, 97.apud SCHNETZELER,R.P.A pesquisa em ensino de química no Brasil: conquistas e perspectivas. Química Nova, Vol. 25, Supl. 1, 14-24, 2002.

KRASILCHIK, M. Análise dos programas de ciências dos cursos de formação do magistério In: PICONEZ, S. C., (org) Caminhos da Formação do Professor de Primeiro Grau: Análise e Reflexão sobre Planos de Ensino da Habilitação Especifica ao Magistério, das Escolas da DRECAP-3. São Paulo : SE/DRECAP-3/FEUSP, 1986. 98p.

CUNHA A.M.O.; Formação Continuada de Professores de Ciências: ,Percepções a Partir de uma Experiência [online] s.d.Disponível na internet via WWW URL:http://www.educacaoonline.pro.br/a formacao continuada.asp.Capturado em 20/02/2007.

KUENZER. A. Z. As políticas de formação: a constituição da identidade do professor sobrante Educação \& Sociedade, ano XX, nº 68, Dezembro 1999. 
LABURU, C.E.; CARVALHO, M. Educação científica: controvérsias construtivistas e pluralismo metodológico. Londrina: EDUEL, 2005. 119p.

LACANALLO, L.F. O Processo De Mudança Conceitual no Ensino de Ciências Naturais na Perspectiva dos Professores das Séries Iniciais do Ensino Fundamental. 2005. 126 folhas. Dissertação (Mestrado em Educação -Área de Concentração: Aprendizagem e Ação Docente) Maringá, 2005.

LANGHI, R.; NARDI, R. Astronomia nos anos iniciais do ensino fundamental:interpretação das expectativas e dificuldades presentes em discursos de professores. Revista de Enseñanza de la Física, v. 20, p. 17-32, 2007..

LIMA, M.E.C.C.; MAUÉS, E. Uma Releitura do Papel da Professora das Séries Iniciais no Desenvolvimento e Aprendizagem de Ciências das Crianças. Revista Ensaio, Belo Horizonte, M.G., volume 8, número 2, páginas 161-175, publicação semestral, dezembro de 2006.

LOPES, M. I. S. A Resistência no Regime Militar: o Docente/Cientista Frente à Política de Ciência e Tecnologia.Universidade Estadual de Campinas. Faculdade de Educação. Tese de Doutorado na Área de Concentração História e Filosofia da Educação. 1997.264p.

Lunn, S., \& Solomon, J. (2000). Primary teachers' thinking about the English national curriculum for science: Autobiographies, warrants, and autonomy. Journal of Research in Science Teaching, 37(10), 1043-1056 apud HUDSON, P. B.; MC ROBBIE, C. J. Evaluating a specific mentoring intervention for preservice teachers of primary science. In PROCEEDINGS INTERNATIONAL EDUCATION RESEARCH CONFERENCE -AARE - NZARE, Auckland, New Zealand(2003)

MARCÍLIO, M.L. História da Escola em São Paulo e no Brasil. São Paulo: Imprensa Oficial do Estado de São Paulo: Instituto Fernand Braudel, 2005.485p.

MAZON, A.B. Aprendizagem de química: Parâmetros de Significação e de Investigação no Ensino de $2^{\circ}$ Grau - Um estudo do material Instrucional do PROQUIM,1986. Faculdade de Educação, Universidade Estadual de Campinas, 1989. 174p.

MEGID NETO, J. Tendências da Pesquisa Acadêmica Sobre o Ensino de Ciências no Nível Fundamental. 1999.229 folhas. Tese de Doutorado. Faculdade de Educação, Universidade Estadual de Campinas, Campinas, 1999.

MINAYO, M.C. Pesquisa social : teoria, método e criatividade, Rio de Janeiro: Ed Vozes, 1994

MOACYR, Primitivo (1936), A Instrução e o Império; subsídios para a História da Educação no Brasil, vol. 1 (1823-1853). São Paulo, Nacional apud SAVIANI, D.2005. História da Formação Docente No 
Brasil : Três Momentos Decisivos. Educação: Revista do Centro de Educação.Santa Maria. volume 30, fascículo 2, páginas 11-26, semestral, 2005.

MOREIRA, M.A. Mapas conceituais e aprendizagem significativa. Adaptado e atualizado, em 1997, de um trabalho com o mesmo título publicado em O ENSINO, Revista Galáico Portuguesa de SócioPedagogia e Sócio-Linguística, Pontevedra/Galícia/Espanha e Braga/Portugal, n 23 a 28: 87-95, 1988. Disponível em: www.if.ufrgs.br/ moreira/mapasport.pdf. Acesso em 10/02/2006.

MUNAKATA, K. O livro didático e a formação do professor.Congresso Brasileiro de Qualidade na Educação-Formação de Professores. Brasília, 2002.

NATIONAL COMMISSION ON TEACHING AND AMERICA'S FUTURE. (1996). What matters most: Teaching for America's future. New York: Author. apud HUDSON, P. B.; MC ROBBIE, C. J. Evaluating a specific mentoring intervention for preservice teachers of primary science. In PROCEEDINGS INTERNATIONAL EDUCATION RESEARCH CONFERENCE -AARE - NZARE, Auckland, New Zealand(2003)

PAIXÃO,C.J. O Positivismo llustrado no Brasil. Revista Trilhas, Belém, volume 01, fascículo 2, páginas 56-35, novembro 2000.

PAQUAY L.; PERRENOUD, P.; ALTET, E.C. Formando professores profissionais: quais estratégias? Quais competências? 2 ed.rev. Porto Alegre: Artmed Editora, 2001.

PARDAL, L.A.; MARTINS, A.M. Formação contínua de professores: concepções, processos e dinâmica profissional. Psicologia da educação. [online]. 2005, vol.20 [citado 21 Junho 2007],p.103117.Disponível em www.<http://pepsic.bvs-psi.org.br/cielso.php>

PENIN, S.T.S.. A Formação de Professores e a Responsabilidade das Universidades. Estudos Avançados, São Paulo, volume. 15, fascículo 42, páginas 317-332, 2001.

PICONEZ, S. C., (org) Caminhos da Formação do Professor de Primeiro Grau: Análise e Reflexão sobre Planos de Ensino da Habilitação Especifica ao Magistério, das Escolas da DRECAP-3. São Paulo : SE/DRECAP-3/FEUSP, 1986. 98p.

PLICAS, L. M. A. . Apoio ao Ensino de Química do Ensino Médio da Região de São José do Rio Preto. In: Sheila Zambello de Pinho; José R. Corrêa Saglietti. (Org.). Livro Eletrônico dos Núcleos de Ensino. São Paulo: Editora Cultura, 2007, v. único, p. 31-45.

PIMENTA,S.G.;GHEDIN ,E.V, (org). Professor Reflexivo no Brasil: Gênese e Crítica de um Conceito $4^{a}$ ed São Paulo: Cortez,2006. 224p.

PIMENTA,S.G. O estágio na formação de professores: unidade teoria e prática? 6.ed, São Paulo: Cortez, 2005. 
A Formação do Professor no Brasil a Partir da Década de 30 In: Funções sóciohistóricas. Idéias - Recursos Humanos para Alfabetização, São Paulo: FDE, v.3, p.35-44, 1988.

PONTE, J. P. Didácticas Específicas e Construção do Conhecimento Profissional. In: INVESTIGAR E FORMAR EM EDUCAÇÃO: 4ํㅡㄹ CONGRESSO DA SPCE, 1999, Porto Actas do $4^{\circ}$ Congresso da SPCE.Porto:. Porto: Sociedade Portuguesa de Ciências da Educação,1999, páginas 59-72.

RABONI, P.C. Atividades Práticas de Ciências Naturais na Formação de Professores para as Séries Iniciais. 2002. 163 folhas. Tese de Doutorado. Faculdade de Educação, Universidade Estadual de Campinas, Campinas, 2002.

REIS FILHO, Casemiro (1995), A educação e a ilusão liberal, $2^{\mathrm{a}}$ ed. Campinas, Autores Associados. apud SAVIANI, D. História da formação docente no Brasil: Três Momentos Decisivos. Educação: Revista do Centro de Educação.Santa Maria. volume 30, fascículo 2, páginas 11-26, semestral, 2005.

RUÉ, J. El Aprendizaje em Autonomia: Possibilidades y Limites. Cadernos Pedagogia Universitária USP. São Paulo, 2007. 36p.

SANTOS, E. P.; BUENO, B. O. Trabalho docente e tecnicismo: a experiência de professoras primárias no estado de são paulo (1960-1980). 27ª REUNIÃO ANUAL DA ANPED Caxambu, MG.

SAVIANI, D.2005. História da formação docente no Brasil: três momentos decisivos. Educação: Revista do Centro de Educação. Santa Maria. volume 30, fascículo 2, páginas 11-26, semestral, 2005.

SCHNEIDER, REGINA P. (1993). A INSTRUÇÃO PÚBLICA NO RIO GRANDE DO SUL: 1770-1889. PORTO ALEGRE: ED. UNIVERSIDADE /UFRGS/EST EDIÇÕES. APUD TANURI, L.M. História da Formação de Professores. Revista Brasileira de Educação. São Paulo. no 14, páginas 61-68, quadrimestral, mai/jun/jul/ago 2000.

SCHNETZELER,R.P.A PESQUISA EM ENSINO DE QUÍMICA NO BRASIL: CONQUISTAS E PERSPECTIVAS. Química. Nova, Vol. 25, Supl. 1, 14-24, 2002.

SCHULMAN, L. Paradigms and researcher programs in the study of teaching: a contemporany perspective. In: Wittrock, M.C. (org) Handbook of research on teaching. $3^{\text {a }}$ ed. New York: Mac Millan,1986, p 4-14 apud BRAGA, A. Os Saberes de Professores que Ensinam Ciências nas Séries Iniciais- Um estudo de caso. Dissertação de Mestrado, São Carlos: UFSCAR, 2005. 146p.

SILVA J. C. Pesquisa Historiográfica em Educação: O Apostolado Positivista do Brasil e a Instrução Pública no Brasil, In: Navegando pela História da Educação Brasileira. Org: José Claudinei Lombardi, 
Demerval Saviani e Maria Isabel Moura Nascimento, Campinas, São Paulo, HISTDBR, 2006, 1 CDROM. Fóton-Midia, 2006.

SILVA, A.F.A. Ensino e Aprendizagem de Ciências nas Séries Iniciais: Concepções de um Grupo de Professoras em Formação. 2006. 153 folhas. Dissertação de Mestrado do Programa PósGraduação Interunidades em Ensino de Ciências - Modalidade Química. Instituto de Química.Universidade de São Paulo, São Paulo, 2006.

SODRÉ, Nelson Werneck. Síntese de história da cultura brasileira. 18.ed. Rio de Janeiro: Civilização Brasileira, 1996. apud ZOTTI, S. A. Organização do Ensino Primário no Brasil: Uma Leitura da História do Currículo Oficial. In: Navegando pela História da Educação Brasileira. Org: José Claudinei Lombardi, Demerval Saviani e Maria Isabel Moura Nascimento, Campinas, São Paulo, HISTDBR, 2006, 1 CD- ROM. Fóton-Midia.

SOUZA, R.F. Política Curricular no Estado de São Paulo nos Anos 1980 e 1990. Cadernos de Pesquisa, São Paulo, volume 36, fascículo 127, páginas 203-231. quadrimestral,2006.

TAMBARA, ELOMAR (1998). Profissionalização, escola normal e feminilização do magistério sul-riograndense de instrução pública, no Séc. XIX. História da Educação, Pelotas,v.2, nº 3, p.35-57. apud TANURI, L.M. história da formação de professores . Revista Brasileira de Educação. São Paulo.no 14, páginas 61-68, quadrimestral, mai/jun/jul/ago 2000.

TANURI, L. A escola nomal no Estado de São Paulo - 1890-1930. São Paulo: FEUSP, 1979. apud EVANGELISTA, O. Formar o mestre na universidade: a experiência paulista nos anos de 1930. Educação e Pesquisa, São Paulo, volume 27, número 2, páginas 247-259,publicação semestral, jul./dez. 2001.

TAVARES, M.I. ; MOREIRA, L.M. ; REZENDE, D.B. Formação continuada de professores do ensino fundamental I em Ciências: os resultados de um curso. IN: VIII CONGRESSO ESTADUAL PAULISTA SOBRE FORMAÇÃO DE EDUCADORES, 2005, Águas de Lindóia. Atas do VIII Congresso Estadual Paulista sobre Formação de Educadores. Águas de Lindóia : UNESP, 2005.

TAYLOR N.;COOL, R.K. Pre-Service Primary Teachers' Models of Kinetic Theory: an Examination of Three Different Cultural Groups. Chemistry Education: Research and Practice in Europe 2002, Vol. 3, No. 3, p. 293-315.

TARDIF, M. Saberes docentes e formação profissional. Vozes 2002 apud BRAGA, A. Os Saberes de Professores que Ensinam Ciências nas Séries Iniciais- Um estudo de caso. Dissertação de Mestrado, São Carlos: UFSCAR, 2005. 146p. 
TENREIRO-VIEIRA,C. Produção e Avaliação de Actividades de Aprendizagem de Ciências para Promover o Pensamento Crítico dos Alunos. Revista Iberoamericana de Educação, vol 33, n 6. http://campus-oei.org/revista/deloslectores/708.pdf.[s.d.]

TEIXEIRA, P.M.A. Educação científica sob a perspectiva da pedagogia histórico-crítica e do movimento C.T.S. no ensino de ciências Ciência \& Educação, v. 9, n. 2, p. 177-190, 2003.

TORO, G. O Labirinto do Fauno. Warner Bros. Pictures. 114min. 2004.

VIDAL, M.;MEMBIELA, P.Investigación sobre una actividad práctica de germinación en la formación de los futuros maestros. Enseñanza de las Ciencias, 2005. Número Extra. VII Congreso.

VILCHES A.;GIL PEREZ, D. Algunos obstáculos e incomprensiones en torno a la sostenibilidad Revista Eureka. Enseñanza y Divulgación de las Ciencias. Sevilla, volume 3, fascículo 3, páginas 507-516, quadrimestral, 2006.

VOGEL, M. ; MOREIRA, L.M. ; TAVARES, M. I.; REZENDE, D.B. . A externação de conceitos em função da mudança linguística. Atas Abrapec, Bauru, v. 5, p. 877-889, 2006.

ZEMBAL-SAUL,C.; BLUMENFELD P.; KRAJCIK J. Influence of guided cycles of planning, teaching, and reflection on prospective elementary teachers' science content representations. Journal of Research in Science Teaching. v. 37, no 4,p. 318-319, 2000.

ZIMMERMANN, E.; EVANGELISTA, P.C.Q. Motivando Pedagogos a Ensinar Física nas Séries Iniciais do Ensino Fundamental. In: IX ENCONTRO DE PESQUISA EM ENSINO DE FÍSICA, 2004, Jaboticatubas - MG. IX Encontro de Pesquisa em Ensino de Física, v. 01. 2004.

ZOTTI, S. A. Organização do ensino primário no Brasil: uma leitura da história do currículo oficial. In: Navegando pela História da Educação Brasileira. Org: José Claudinei Lombardi, Demerval Saviani e Maria Isabel Moura Nascimento, Campinas, São Paulo, HISTDBR, 2006, 1 CD- ROM. Fóton-Midia, 2006.

ZOTTI, Solange Aparecida. Sociedade, educação e currículo no Brasil: dos jesuítas aos anos de 1980. Campinas: Autores Associados; Brasília: Editora Plano, 2004 apud ZOTTI, S. A. Organização do Ensino Primário no Brasil: Uma Leitura da História do Currículo Oficial. In: Navegando pela História da Educação Brasileira. Org: José Claudinei Lombardi, Demerval Saviani e Maria Isabel Moura Nascimento, Campinas, São Paulo, HISTDBR, 2006, 1 CD- ROM. Fóton-Midia, 2006. 


\section{Respostas do Questionário Anexo 1}

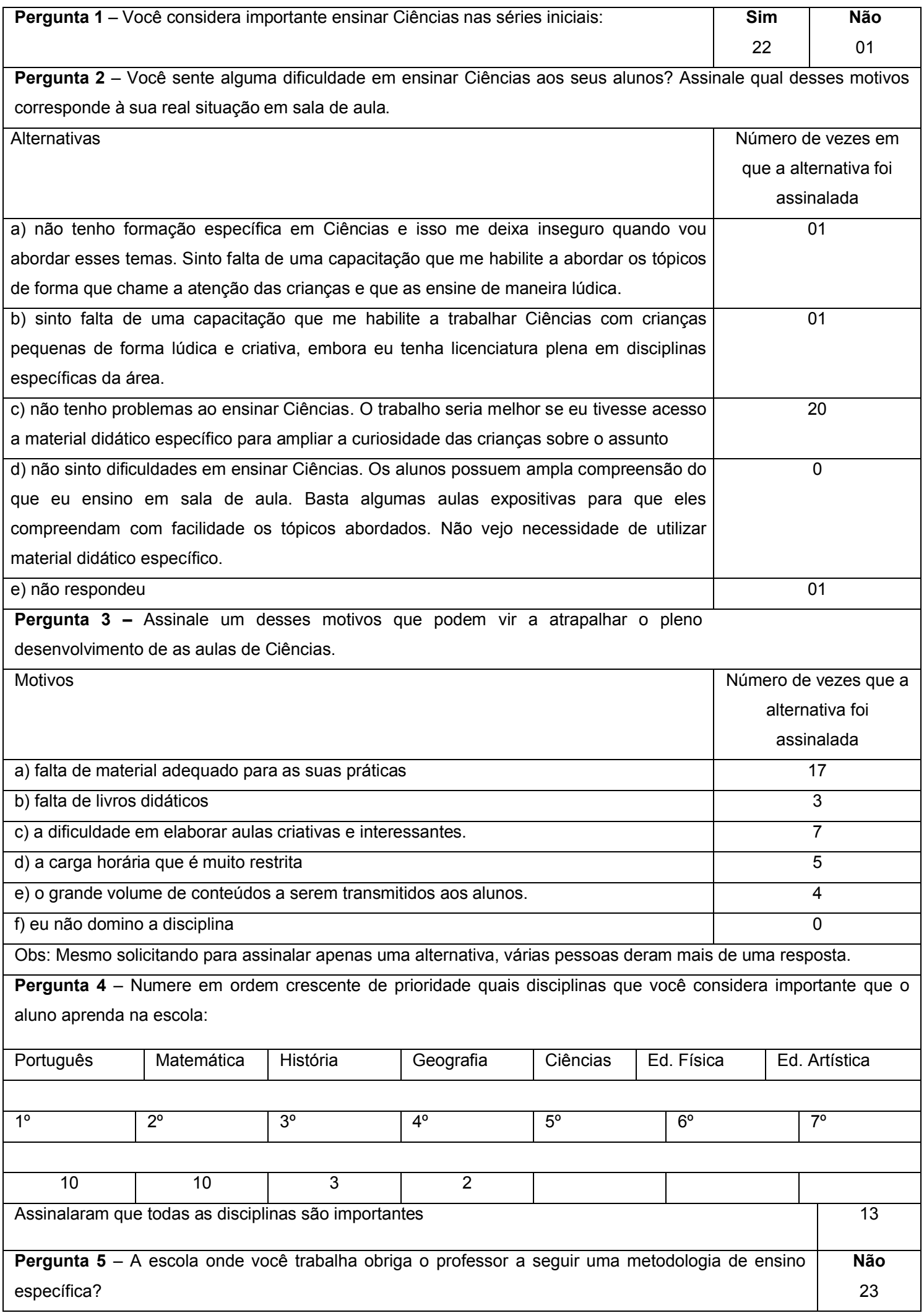




\section{PlanetaÁgua}

Anexo 2

Guilherme Arantes

Composição: Desconhecido

Água que nasce na fonte serena do mundo

E que abre um profundo grotão

Água que faz inocente riacho e deságua na corrente do ribeirão

Águas escuras dos rios que levam a fertilidade ao sertão

Águas que banham aldeias e matam a sede da população

Águas que caem das pedras no véu das cascatas, ronco de trovão

$\mathrm{E}$ depois dormem tranqüilas no leito dos lagos, no leito dos lagos

Água dos igarapés, onde lara, a mãe d'água é misteriosa canção

Água que o sol evapora, pro céu vai embora, virar nuvem de algodão

Gotas de água da chuva, alegre arco-íris sobre a plantação

Gotas de água da chuva, tão tristes, são lágrimas na inundação

Águas que movem moinhos são as mesmas águas que encharcam o chão

E sempre voltam humildes pro fundo da terra, pro fundo da terra

Terra, planeta água

Terra, planeta água

Terra, planeta água

Água que nasce na fonte serena do mundo

E que abre um profundo grotão

Água que faz inocente riacho e deságua na corrente do ribeirão

Águas escuras dos rios que levam a fertilidade ao sertão

Águas que banham aldeias e matam a sede da população

Águas que movem moinhos são as mesmas águas que encharcam o chão

E sempre voltam humildes pro fundo da terra, pro fundo da terra

Terra, planeta água

Terra, planeta água

Terra, planeta água

Terra, planeta água

Terra, planeta água

Terra, planeta água. 
Encontro1 Mapa conceitual coletivo

Anexo 3 
Encontro 02

Anexo 4

Mapa Conceitual Individual 


\section{Anexo 5 \\ O que são Mapas Conceituais?}

A teoria que está por detrás do conceito de mapeamento conceitual é a teoria cognitiva de aprendizagem de David Ausubel. Trata-se de uma técnica desenvolvida em meados da década de setenta por Joseph Novak e seus colaboradores na Universidade de Cornell, nos Estados Unidos.

O conceito básico da teoria de Ausubel é o da aprendizagem significativa. A aprendizagem é dita significativa quando uma nova informação adquire significados para o aprendiz através de uma espécie de ancoragem em aspectos relevantes da estrutura cognitiva presente do indivíduo, em conceitos, idéias, proposições já existentes em sua estrutura de conhecimentos (ou de significados) com determinado grau de clareza, estabilidade e diferenciação. Esses aspectos relevantes da estrutura cognitiva que servem de ancoradouro para a nova informação são chamados "subsunçores". O termo ancorar, no entanto, apesar de útil como uma primeira idéia do que é aprendizagem significativa não dá uma imagem da dinâmica do processo. Na aprendizagem significativa há uma interação entre o novo conhecimento e o já existente, na qual ambos se modificam. A medida que o conhecimento prévio serve de base para a atribuição de significados à nova informação, ele também se modifica . Os subsunçores vão adquirindo novos significados, se tornando mais diferenciados, mais estáveis. Novos subsunçores vão se formando; subsunçores vão interagindo entre si. A estrutura cognitiva está cosntantemente se reestruturando durante a aprendizagem signficativa. O processo é dinâmico, o conhecimento vai sendo construído.

Aprender significativamente implica atribuir significados e estes têm sempre componentes pessoais. Aprendizagem sem atribuição de significados pessoais, sem relação com o conhecimento preexistente, é mecânica não significativa. Na aprendizagem mecânica, o novo conhecimento é armazenado de maneira arbritária e literal na mente do indivíduo. Ele não interage significativamente com a estrutura cognitiva preexistente, não adquire significados. Durante um certo período de tempo , a pessoa é inclusive capaz de reproduzir o que foi aprendido mecanicamente, mas não significa nada para ela.

O mapeamento conceitual é uma técnica muito flexível e em razão disso pode ser usado em diversas situações para diferentes finalidades: instrumento de análise de currículo, técnica didática, recurso de aprendizagem, meio de avaliação (Moreira e Buchweitz, 1993 apud Moreira,1997)

É possível traçar-se um mapa conceitual para uma única aula, para uma unidade de estudo, para um curso ou, até mesmo, para um programa educacional completo. A diferença está no grau de generalidade e inclusividade dos conceitos colocados no mapa. Um mapa envolvendo apenas conceitos gerais, inclusivos e organizacionais pode ser usado como referencial para o planejamento de um curso inteiro, enquanto que um mapa incluindo somente conceitos específicos pouco inclusivos e organizacionais pode ser usado como referencial para o planejamento de um curso inteiro, enquanto que um mapa incluindo somente conceitos específicos pouco inclusivos pode auxiliar na seleção de determinados materiais instrucionais. Isso quer dizer que mapas conceituais podem ser importantes mecanismos para focalizar a atenção do planejador de currículo na distinção entre o conteúdo curricular e conteúdo instrumental, ou seja entre o conteúdo que se espera que seja aprendido e aquele que serve de veículo para a aprendizagem. O conteúdo curricular está contido em fontes de conhecimento tais como artigos de pesquisa, ensaios, poemas, livros. Mapas conceituais podem ser úteis na análise desses documentos a fim de tornar adequado para a instrução o conhecimento neles contido. Considera-se aqui que o currículo se refere a um conjunto de conhecimentos. Sendo assim, a análise da estrutura do conhecimento implica a análise do currículo e o mapeamento conceitual pode ser um instrumento útil de análise. 
Os mapas conceituais não são instrutivos, devem ser explicados pelo professor. Além disso, embora possam ser usados para dar uma visão geral do tema em estudo é preferível usá-los quando os alunos já tem uma certa familiaridade com o assunto, de modo que sejam potencialmente significativos e permitam a integração, reconciliação e diferenciação de significados de conceitos (Moreira, 1980).

\section{Como construir um mapa conceitual}

1. Identifique os conceitos-chave do conteúdo que vai mapear e ponha-os em uma lista. Limite entre 6 e 10 o número de conceitos.

2. Ordene os conceitos, colocando o(s) mais geral(is), mais inclusivo(s), no topo do mapa e, gradualmente, vá agregando os demais até completar o diagrama de acordo com o princípio da diferenciação progressiva.

3. Se o mapa se refere, por exemplo, a um parágrafo de um texto, o número de conceitos fica limitado pelo próprio parágrafo. Se o mapa incorpora também o seu conhecimento sobre o assunto, além do contido no texto, conceitos mais específicos podem ser incluídos no mapa.

4. Conecte os conceitos com linhas e rotule essas linhas com uma ou mais palavras chave que explicitem a relação entre os conceitos. Os conceitos e as palavras-chave devem sugerir uma proposição que expresse o significado da relação.

5. Evite palavras que apenas indiquem relações triviais entre os conceitos. Busque relações horizontais e cruzadas.

6. Exemplos podem ser agregados ao mapa, embaixo dos conceitos correspondentes. Em geral, os exemplos ficam na parte inferior do mapa.

7. Geralmente, o primeiro intento de mapa tem simetria pobre e alguns conceitos ou grupos de conceitos acabam mal situados em relação a outros que estão mais relacionados.

8. Talvez neste ponto você já comece a imaginar outras maneiras de fazer o mapa, outros modos de hierarquizar os conceitos. Lembre-se que não há um único modo de traçar um mapa conceitual. À medida que muda sua compreensão sobre as relações entre os conceitos, ou à medida que você aprende, seu mapa também muda. Um mapa conceitual é um instrumento dinâmico, refletindo a compreensão de quem o faz no momento em que o faz.

9. Compartilhe seu mapa com colegas e examine os mapas deles. Pergunte o que significam as relações, questione a localização de certos conceitos, a inclusão de alguns que não lhe parecem importantes, a omissão de outros que você julga fundamentais. O mapa conceitual é um bom instrumento para compartilhar, trocar e "negociar" significados.

Texto adaptado do artigo escrito pelo Prof.Dr. Marco Antonio Moreira ;Instituto de Física da UFRGS.

Acesso em 06/09/2006.

http://www.if.ufrgs.br/ moreira/mapasport.pdf\#search=\%22Mapas\%20Conceituais\%22

\section{Questão:}

1) Qual seria a possível utilização da dinâmica representada no encontro anterior? Essa dinâmica se restringe somente ao tema água? Justifique. 


\section{Anexo 6 \\ CAPÍTULO I - O QUE É UMA REAÇÃO QUÍMICA ? \\ TEXTO 1-1 \\ A QUÍMICA É VELHA?}

Em épocas remotas, nossos antepassados do tempo das cavernas ainda não sabiam explicar quase nada sobre as transformações que ocorriam no mundo material por falta de um conjunto de conhecimentos organizados. Naquela época, algum destes nossos antepassados deve ter-se assustado muito quando viu o fogo pela primeira vez. Possivelmente imaginou que fosse a manifestação do poder de algum deus. No entanto, nosso antepassado aprendeu a utilizar o fogo em seu benefício, embora, provavelmente, tenha se queimado várias vezes. Mas...valeu, já que ele deve também ter descoberto o churrasco! Este nosso antepassado pode ser considerado o pioneiro entre os estudantes das transformações químicas.

Conhecer o fogo e dominá-lo foi muito importante: o fogo afugentava animais, iluminava e aquecia as cavernas, permitia cozinhar alimentos e construir recipientes de barro. Como os nossos antepassados aprenderam a produzir o fogo, não precisavam mais esperar que lhes fosse enviado através dos raios. O domínio do fogo provocou uma transformação de costumes, trazendo vários benefícios. Afinal um churrasco de mamute era muito mais gostoso do que mamute cru!

Assim como os nossos antepassados aprenderam a produzir e a utilizar o fogo, outros conhecimentos foram sendo acumulados e utilizados para atender as necessidades básicas dos seres humanos. Cada nova descoberta propiciava uma supremacia do homem sobre os animais. às vezes, infelizmente, de uns homens sobre outros homens. A primeira nação que aprendeu a forjar o ferro deve ter imposto sua supremacia militar sobre outras nações. Por exemplo, Júlio César, imperador romano, não entendia porque seus inimigos, os bretões, retiravam-se dos combates periodicamente. Só depois de algum tempo ele descobriu que os bretões precisavam desentortar suas espadas, já que ainda não haviam descoberto o aço - este conhecimento, que os romanos dominavam, não havia sido divulgado para outros povos.

Hoje em dia o mundo se transforma muito mais rapidamente do que em outras épocas. Quando nossos bisavós tinham a idade que temos hoje o homem nem sonhava em ir à Lua, não conhecia a bomba atômica, a Coca-Cola ou a televisão. Certamente o mundo tranformou-se muito desde então. Todavia, uma pessoa que tenha vivido há um milênio não poderia afirmar o mesmo com relação ao tempo de seus bisavós. De fato, além de, freqüentemente, não conhecer muito mais coisas que seus antepassados, às vezes conhecia até menos.

Muitos conhecimentos devem ter-se perdido por falta de comunicação, tendo que ser redescobertos. Por exemplo, sabe-se hoje, que o povo da Mesopotâmia já fazia sabão há 5.000 anos. Entretanto na Grécia Antiga, em época 3000 anos posterior à da civilização que existira na Mesopotâmia, não se tomava banho. Os gregos, reconhecidos até hoje como um povo de muita sabedoria, não conheciam o sabão. Assim, limpavam-se com óleo de oliva e raspavam a sujeira com um objeto semelhante a uma faca sem corte. Sabe-se também que embora a pólvora tenha sido descoberta primeiramente na China, houve várias redescobertas em épocas e locais diferentes. Com mais um exemplo, pode-se citar o fato notório do oxigênio ter sido descoberto por Scheele na Suécia em 1722 e redescoberto dois anos depois, por Priestley, na Inglaterra.

Para evitar tais situações procura-se comunicar e divulgar as descobertas científicas pois assim, além dos eventos descritos poderem ser repetidos, contribui-se para a descoberta de novos eventos. Em síntese, há muito tempo o homem quer 
compreender o mundo e suas transformações ; a acumulação e a divulgação do conhecimento facilitam esta compreensão do mundo e o domínio sobre a natureza.

O conhecimento químico vem sendo organizado há cerca de 200 anos, contribuindo para a explicação de vários dos aspectos envolvidos nas transformações que ocorrem na natureza como para a previsão e a descoberta de novas transformações e materiais.

Atualmente, a utilização do conhecimento químico permite ao homem a produção de medicamentos, bombas, combustíveis, plásticos, agrotóxicos e tintas, além de uma infinidade de outros materiais. Nosso antepassado das cavernas que produziu o fogo pela primeira vez nem sonharia serem possíveis processos como estes!

Muitos dos processos que ocorrem em nossa vida diária podem ser compreendidos através do estudo da química. Conhecer química é importante para compreender vários dos processos que ocorrem em nosso próprio organismo, além daqueles que estão envolvidos em nossa alimentação, na produção de matérias-primas para a confecção do nosso vestuário, na geração de energia para os nossos meios de locomoção, na obtenção de metais a partir dos minérios e em infinidades de outros eventos e atividades com que nos deparamos, a cada momento, diariamente.

Estão em permanente debate, atualmente, questões como a substituição de fontes não renováveis de energia através da transformação da bio-massa, a poluição ambiental ou a utilização de energia nuclear. Para compreender a abrangência destas questões e poder tomar posições críticas como cidadão também é necessário conhecer os princípios fundamentais da química. Finalmente é importante refletir sobre a necessidade de reinvidicar a utilização adequada do conhecimento químico de forma que ele possa, de fato, contribuir par a melhoria da qualidade de vida das populações.

Atividade I-1

\section{OBSERVANDO TRANFORMAÇÕES}

As transformações que ocorrem diariamente são tantas e tão freqüentes que você talvez ainda não tenha observado cuidadosamente muitas delas. Você já pensou sobre como reconhecer a ocorrência de uma determinada transformação, por exemplo, o apodrecimento de um fruto?

Nesta atividade você será convidado a refletir sobre transformações que ocorrem na sua vida diária. Dentre elas relacione no máximo dez na tabela l-1 e anote, também, como você pôde reconhecer que se tratava de realmente de uma transformação.

Tabela I-1

\begin{tabular}{|l|l|}
\hline Transformação & $\begin{array}{l}\text { Como você pôde reconhecer a } \\
\text { tranformação? }\end{array}$ \\
\hline & \\
\hline
\end{tabular}

Texto 1-2 - Reconhecendo Transformações

Na tabela I - 1, você listou várias transformações que ocorrem na sua vida diária e indicou como pôde reconhecer sua ocorrência. É provável que você as tenha 
identificado através da comparação de algumas características do(s) material (is) antes e após a ocorrência da transformação. Por exemplo, podemos reconhecer o apodrecimento de um fruto comparando algumas características deste fruto antes e após o apodrecimento. De fato, características como a cor, o sabor e o cheiro são bem diferentes no fruto fresco e no fruto podre, permitindo identificar a ocorrência da transformação.

Quando se pretende estudar um fenômeno - no caso, o apodrecimento de um fruto- geralmente não interessam todas as outras mudanças que se processem no universo em conseqüência deste fenômeno, mas apenas as que ocorrem numa porção delimitada do universo. A esta porção do universo que é separada para estudo dá-se o nome de sistema. No caso do estudo do apodrecimento de um fruto o apodrecimento é o fruto.

A escolha do sistema está associada ao problema que se queira abordar. Por exemplo, imagine que a questão refira-se à transformação de minério de ferro em ferro metálico. Se o problema se referir apenas à transformação em si, o sistema é apenas o minério. Se a questão abranger a proteção ambiental, o sistema é o minério mais o meio ambiente. Pode-se, também, pensar no aspecto da extração do minério. No caso o sistema seria a jazida de minério, em termos de sua extensão, facilidade de acesso, distância dos centros consumidores e assim por diante.

A cor, o cheiro, a temperatura, a massa e o volume são algumas das propriedades utilizadas para descrever um sistema. A descrição adequada de um sistema define 0 estado do sistema. A descrição do sistema antes da transformação define o estado inicial do sistema enquanto a descrição feita após a transformação define o estado final do sistema. Portanto, a comparação entre os estados inicial e final de um sistema fornece indicações que nos permitem reconhecer a ocorrência de transformações neste sistema.

Vamos agora, centrar nossa atenção em um tipo particular de transformação, isto é , a transformação química. As transformações químicas são, usualmente, denominadas reações químicas. O objetivo do próximo guia experimental é que você aprenda o que é uma reação química e como reconhecer as indicações de ocorrência deste tipo de transformação.

\section{Guia experimental I - 1 \\ O que é uma reação química?}

\section{I - Introdução.}

A cada instante que passa ocorrem transformações à nossa volta. $\dot{E}$ um fruto que apodrece, é a água dos rios e dos mares que se transformam em nuvens, é o nosso próprio organismo que transforma os alimentos. Muitas destas transformações são reações químicas, muitas outras não o são. Então, como é possível identificar as reações químicas?

Como vimos no texto anterior,.é possível reconhecer a ocorrência de uma tranformação qualquer - por exemplo, o enferrujamento de um portão - comparando as características do portão antes e após o enferrujamento, isto é pela comparação dos estados final e inicial deste sistema. Mas será que esta comparação pode nos fornecer dados que permitam distinguir as reações químicas entre a infinidade de transformações que observamos no nosso dia a dia?

Neste experimento, você investigará os vários sistemas com o objetivo de identificar quais propriedades dos mesmos facilitam o reconhecimento da ocorrência de reações químicas, permitindo distinguí-las de outros tipos de transformações. 


\section{II - Material Necessário}

\begin{tabular}{|l|l|}
\hline 10 tubos de ensaio & 01 estante para tubos de ensaio \\
\hline 01 almofariz e pistilo & 01 espátula \\
\hline 01 pinça de madeira & 01 bico de Bunsen ou lamparina \\
\hline enxofre em pó & Açúcar \\
\hline cabelo & ferro em limalhas \\
\hline ferro (prego) & magnésio em raspas \\
\hline água & solução aquosa de sulfato de cobre II \\
\hline solução aquosa de hidróxido de sódio & solução aquosa de ácido clorídrico \\
\hline solução aquosa de nitrato de chumbo II & solução aquosa de iodeto de potássio. \\
\hline
\end{tabular}

III- Procedimento

Trabalhe com segurança:

- evite que enxofre e as soluções de sulfato de cobre II, hidróxido de sódio ou ácido clorídrico atinjam sua pele; se isto ocorrer, lave imediatamente o local afetado com bastante água;

- evite queimaduras manuseando com cuidado os materiais quentes;

- use espátula limpa para retirar os sólidos dos frascos;

- execute apenas os testes indicados explicitamente neste guia.

Em caso de acidente, aviso ao professor imediatamente.

1. Aquecimento de cabelo - execute o procedimento descrito a seguir:

a) coloque alguns fios de cabelo num tudo de ensaio limpo e seco;

b) observe e descreva na tabela de dados as características do material que constitui o sistema no estado inicial;

c) proceda ao aquecimento do material contido no tubo de ensaio seguindo as instruções dadas pelo professor;

d) observe e anote na tabela de dados as características do material após o aquecimento, isto é, as características do sistema no estado final.

2. Aquecimento de açúcar - repita o procedimento descrito no item 1 colocando uma ponta de espátula de açúcar no tubo de ensaio em vez de cabelo.

3. Aquecimento de água - repita o procedimento do item 1 , colocando água no tubo de ensaio até cerca de $2 \mathrm{~cm}$ de altura, em vez de cabelo.

4. Aquecimento de enxofre em pó - repita o item 1, colocando uma ponta de espátula de enxofre em pó no tubo de ensaio, em vez de cabelo.

5. Adição de ferro a enxofre - siga o procedimento descrito abaixo:

a) observe as características do ferro em limalhas e do enxofre em pó separadamente e anote-as na tabela de dados;

b)coloque uma ponta de espátula do ferro em limalhas no almofariz;

c) acrescente igual quantidade de enxofre em pó, triture e anote suas observações na tabela de dados;

d) reserve o material triturado para o próximo teste.

6) Aquecimento da mistura ferro-enxofre - execute o procedimento descrito a seguir.

a) transfira a mistura ferro-enxofre do almofariz para um tubo de ensaio ( ou tubo de aquecimento); 
b) aqueça o tubo até a incandescência;

c) anote suas observações na tabela de dados.

7. Adição de sal de cozinha à água - execute o procedimento descrito a seguir:

a) observe as características da água e do sal de cozinha e anote na tabela de dados;

b) coloque água em um tubo de ensaio limpo até cerca de $2 \mathrm{~cm}$ de altura;

c) adicione uma ponta de espátula de sal de cozinha à água contida no tubo de ensaio, agite e anote suas observações na tabela de dados.

8. Adição de ferro à solução aquosa de sulfato de cobre II - repita o procedimento descrito no item 7 substituindo os materiais utilizados anteriormente por solução de sulfato de cobre II e um prego de ferro.

9. Adição de magnésio em raspas à solução aquosa de ácido clorídrico - repita o procedimento descrito no item 7 , substituindo os materiais utilizados anteriormente por solução de ácido clorídrico e raspas de magnésio.

10. Adição de solução aquosa de ácido clorídrico à solução aquosa de nitrato de chumbo II - execute o procedimento descrito a seguir:

a) observe as características das duas soluções separadamente e anote-as na tabela de dados;

b) coloque num tubo de ensaio limpo uma quantidade da solução de ácido clorídrico suficiente para atingir cerca de $1 \mathrm{~cm}$ de altura;

c) adicione uma quantidade igual da solução de nitrato de chumbo II e agite;

d) anote suas observações na tabela de dados.

11. Adição de solução aquosa de iodeto de potássio à solução aquosa de nitrato de chumbo II - siga o procedimento descrito para o teste 10 .

12. Adição de solução aquosa de hidróxido de sódio à solução aquosa ácido clorídrico - siga o procedimento descrito para o teste 10.

13. Adição de solução aquosa de hidróxido de sódio à solução aquosa de sulfato de cobre II - siga o procedimento descrito para o teste 10.

14. Após a realização da experiência, lave e guarde todo o material utilizado.

IV- TABELA DE DADOS

Complete a tabela a seguir de acordo com as suas observações. Durante o preenchimento da tabela considere como estado final do sistema o momento em que este tenha atingido a temperatura ambiente.

\begin{tabular}{|l|l|l|l|l|l|}
\hline Teste & Sistema & $\begin{array}{l}\text { Estado } \\
\text { Inicial }\end{array}$ & $\begin{array}{l}\text { Durante a } \\
\text { transformação }\end{array}$ & Estado final & $\begin{array}{l}\text { Comparação } \\
\text { entre estados } \\
\text { inicial e final }\end{array}$ \\
\hline 1 & & & & & \\
\hline 2 & & & & & \\
\hline 3 & & & & & \\
\hline
\end{tabular}




\begin{tabular}{|l|l|l|l|l|l|}
\hline 4 & & & & & \\
\hline 5 & & & & & \\
\hline 6 & & & & & \\
\hline 8 & & & & & \\
\hline 9 & & & & & \\
\hline 10 & & & & & \\
\hline 11 & & & & & \\
\hline 12 & & & & & \\
\hline 13 & & & & & \\
\hline
\end{tabular}

\section{V- ANÁLISE DE DADOS}

1- Em qual (quais) teste(s) você observou:

a)mudança de cor

b) mudança de forma

c) liberação de gás

d) aparecimento de um novo estado físico

e) formação de precipitado ( precipitado é um sólido insolúvel que se forma à partir da mistura de duas soluções)

f) mudança de odor

g)liberação de calor

h)alteração de quantidade de material 
i) outras mudanças

2) Quais dos itens acima podem ser considerados como evidência (indicações de formaçaõ de novo(s) material (mateirais) ?

3) Em qual (quais) critério(s) você se baseou para responder a questão 2?

4) No que você se baseou para concluir que não houve formação de novos materiais em algum (ou alguns) do(s) sistema(s)?

\section{VI- CONCLUSÕES}

Resfriar a água líquida até a formação de gelo, rasgar uma forlha de papel, fundir a taça Jules Rimet, misturar ferro e enxofre e aquecer água são exemplos de transformações que recebem o nome de transformações físicas. Por outro lado, no aquecimento do cabelo, no apodrecimento de um fruto e na adição de solução de hidróxido de sódio à solução de sulfato de cobre II, por exemplo, há ocorrência de transformações químicas. Para responder às questões seguintes, consulte também a tabela de dados e suas respostas às questões de análise de dados.

1- Em que testes você acha que houve transformações químicas? Justifique sua resposta.

2- Quando se dispara uma lâmpada de flash do tipo descartável observa-se uma intensa luminosidade e a formação de um pó branco. Por que você pode dizer que ocorreu uma reação química neste processo?

3- Quais são as principais evidências de ocorrência de reação química?

4- A obtenção do gelo a partir do resfriamento da água líquida é uma transformação física. Por que se pode fazer esta afirmação?

5- Como você pode dizer se uma transformação é física ou química?

Através da análise dos dados coletados durante o experimento, foi possível concluir que nas reações químicas há formação de novos materiais. Dentre as inúmeras transformações que podem ser observadas diariamente, inclusive aquelas que ocorrem oem organismos vivos, muitas são classificadas como reações químicas. Nestas transformações o estado final do sistema é constituído por material (materiais) diferente (s) daqueles que formavam o estado inicial. $O$ fato de se formarem materiais novos é também o que distingue uma reação química de um processo físico pois, neste, a transformação não causa formação de um ou mais materiais novos. Numa reação química, os materiais de partida são chamados de reagentes e os novos materiais formados são chamados de produtos.

\section{VII - EXERCÍCIOS}

1- Aqueceu-se um sólido vermelho num tubo de ensaio. Depois de algum tempo de aquecimento detectou-se a liberação de um gás incolor e a formação de um líquido prateado. Pergunta-se:

a) Quais são os materiais que compõem o sistema em estudo?

b) Qual é o estado inicial do sistema? 
c) Qual é o estado final do sistema?

d) Ocorreu reação química? Qual é a evidência?

2- Quando um comprimido de Sonrisal é colocado em água ocorre um processo físico ou uma reação química? Explique sua resposta.

3- Quando se aquece a água há liberação de um gás. Está ocorrendo uma reação química? Explique sua resposta.

4- Retome o quadro ( tabela I-1) construído na Atividade I-1 e classifique as transformações ali relacionadas como reação química ou processo físico.

5- Dadas as informações a seguir, classifique-as em físicas ou químicas:

a) escurecimento de uma colher de prata

b) crescimento das unhas

c) amolecimento de um picolé de limão

d) rasgar uma folha de papel

e) cortar os cabelos

f) queima de uma acha de lenha

g) fritar um bife

h) azedar o vinho

i) ferver água

Em que critério você se baseou para proceder a esta classificação?

\section{VIII- QUESTÕES PARA DISCUSSÃO}

1- Quando não se nota uma evidência pode-se garantir que não tenha ocorrido reação química no sistema?

2- Pode-se garantir que tenha ocorrido uma reação química num sistema considerando-se apenas a observação de evidências?

3- Por que é possível, muitas vezes, reconhecer a ocorrência de uma reação química através da observação de evidências?

\section{Texto 1- 3 \\ SINTESE}

Pode-se reconhecer a ocorrência de transformações em um sistema verificando se houve alteração nas propriedades que caracterizam seus estados inicial e final. Embora, freqüentemente, estas alterações sejam perceptíveis aos nossos sentidos, em vários sistemas ocorrem transformações sem que se observe evidências. Por exemplo, quando você misturou as soluções de hidróxido de sódio e ácido clorídrico, não houve evidências observáveis embora tenha ocorrido uma transformação. Neste caso para concluir que ocorreu uma transformação é necessário recorrer a uma análise mais detalhada do sistema, utilizando instrumentos capazes de detectar as alterações ocorridas em suas propriedades.

Por outro lado, mesmo que se observe evidências, tem-se apenas uma indicação e não uma garantia sobre o tipo de transformação ocorrida. No caso da mistura de enxofre à limalha de ferro, por exemplo, ocorreu uma alteração na cor do sistema que, entretanto , não se deve à formação de um novo material.

Como se poderia ter maior certeza de que uma reação química tenha de fato ocorrido num determinado sistema?

Para responder a esta questão é necessário que se conheça outras propriedades, além das já estudadas neste capítulo ( cor, cheiro, estado físico, etc...) que caracterizem melhor os estados inicial e final do sistema em estudo, permitindo caracterizar os materiais envolvidos no processo de transformação. De fato, a simples 
observação de uma evidência não permite identificar os materiais formados numa reação. Por exemplo, quando se mistura soluções aquosas de ácido clorídrico e nitrato de chumbo II forma-se um precipitado branco. Ao se juntar soluções aquosas de cloreto de bário e sulfato de sódio também se forma um precipitado branco. Esses precipitados são um mesmo material ou são materiais diferentes? Você poderá responder a esta pergunta após estudar o capítulo II.

\section{Capitulo 2 \\ Como se reconhece uma reação química?}

No Capítulo anterior concluímos que não se pode garantir a ocorrência de uma reação química somente através da observação de evidências. Então, como podemos ter certeza de que se tenha formado um novo material?

A caracterização de um material é muito importante. Por exemplo, o medicamento conhecido como aspirina é uma mistura de um material chamado ácido acetilsalisílico com outro material chamado amido, sendo que o componente ativo é o ácido acetilsalisílico. $\mathrm{O}$ ácido empregado na fabricação dos comprimidos é obtido através de uma reação química. É necessário, portanto, verificar as propriedades do ácido obtido para se ter certeza de que o produto da reação seja realmente o ácido acetilsalisílico e não outra substância. Através da determinação dos valores das propriedades do ácido obtido é possível, também, saber se ele está puro ou se está misturado com outros materiais, que poderiam até mesmo ser nocivos ao organismo.

As propriedades freqüentemente usadas para identificar as substâncias e distinguilas de misturas são chamadas propriedades físicas. Nas próximas experiências você vai estudar as seguintes propriedades físicas: ponto de fusão, ponto de ebulição, densidade e solubilidade. Ao final deste estudo, você será capaz de identificar uma substância pura e distingui-la de uma mistura através da determinação dessas propriedades

\section{Guia Experimental II-1 \\ Ponto de Ebulição}

\section{I - Introdução}

É muito fácil distinguir uma porção de água de uma porção de vinho tinto. Através de um simples olhar tem-se, imediatamente, a resposta: a água é incolor e o vinho é avermelhado. Entretanto, como se poderia diferenciar uma porção de água do mar filtrada de uma porção de água pura, sem experimentar o gosto? Ou, como se poderia distinguir uma porção de água de uma de álcool, sem sentir o odor?

As respostas a estas questões podem ser dadas através do estudo das propriedades desses materiais. O ponto de ebulição é uma das propriedades mais indicadas seja para distinguir, seja para identificar, líquidos. Quando se aquece um líquido até uma determinada temperatura ele começa a ferver, ou seja, entra em ebulição. A temperatura em que ocorre a ebulição de um material é chamada de ponto de ebulição.

Mas, como se poderia utilizar esta propriedade - o ponto de ebulição - para caracterizar uma substância e diferenciá-la de uma mistura?

Você pode responder a esta pergunta realizando o experimento a seguir. Neste experimento, você vai analisar a variação da temperatura com o tempo durante o 
aquecimento e ebulição de um líquido puro e de uma mistura. Ao final deste experimento você será capaz de:

$\checkmark$ definir o que é substância

$\checkmark$ julgar se o ponto de ebulição de uma substância pode ser considerado uma constante física;

$\checkmark$ verificar se o ponto de ebulição pode ser utilizado para caracterizar uma substância e distingui-la de uma mistura .

\title{
II - Material Necessário
}

\author{
glicerina 2 béqueres de $100 \mathrm{~mL}$ \\ água 1 bagueta \\ 1 tripé e 1 tela de amianto \\ 1 bico de Bunsen (ou lamparina) \\ 1 termômetro de 10 a $110^{\circ} \mathrm{C}$ \\ 1 cronômetro (ou relógio com marcador de \\ segundos)
}

\section{III - Procedimento}

1. Trabalhe com segurança: Evite queimaduras, não pegando os materiais quentes com as mãos. Se a bancada do laboratório for de azulejo, não coloque materiais de vidro quentes diretamente sobre a bancada; coloque-os sobre uma tela de amianto.

2. Monte a aparelhagem necessária para aquecer a água no béquer conforme indicado na Figura II-1.

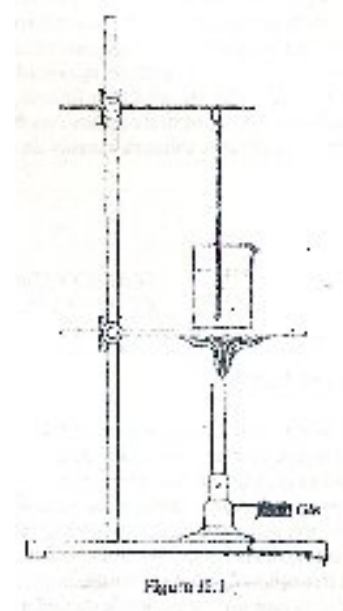

3. Coloque água no máximo até a metade do volume do béquer, conforme as instruções do seu professor.

4. Coloque o termômetro na água e inicie o aquecimento. Durante o aquecimento agite a água com o próprio termômetro, CUIDADOSAMENTE. 
5. A cada 30 segundos, leia a temperatura da água e anote na tabela de dados. Assinale a temperatura em que se inicia a ebulição.

6. Após o início da ebulição, continue marcando a temperatura da água, a cada 30 segundos, durante 3 minutos.

7. Coloque no outro béquer alguns mililitros de glicerina, conforme as instruções do seu professor. Adicione água até no máximo a metade do volume do béquer e agite com a bagueta para que a glicerina se misture completamente.

8. Repita o procedimento com esta mistura de água e glicerina.

\section{IV - Tabela de Dados}

Reproduza as tabelas abaixo no seu caderno, deixando espaço suficiente para o registro de dados.

Água

Aquecimento

\begin{tabular}{|l|l|l|}
\hline Tempo & Temperatura & \\
\hline & & \\
& & \\
& & \\
\hline
\end{tabular}

Glicerina + Água

Aquecimento

\begin{tabular}{|l|l|l|}
\hline Tempo & Temperatura & \\
\hline & & \\
& & \\
& & \\
\hline
\end{tabular}

V- Análise de Dados

1. Para analisar e comparar melhor os dados obtidos no experimento construa o gráfico que representa $\mathrm{o}$ comportamento da temperatura durante 0 
aquecimento da água (temperatura em ordenadas $\mathrm{x}$ tempo em abcissas). $\mathrm{Na}$ mesma escala, construa também o gráfico que representa o aquecimento da mistura de água e glicerina.

2. Indique, em cada gráfico, os pontos que, com certeza, correspondem à ebulição dos materiais.

3. Quais são as temperaturas em que ocorrem a ebulição da água e da mistura de água e glicerina?

4. A temperatura em que ocorre a ebulição da água é constante? E da mistura, também? Explique sua resposta.

5. Compare seus dados com os valores obtidos por outras equipes que usaram outra quantidade de água e uma mistura de água com glicerina de outra proporção; responda às questões seguintes explicando suas respostas.

6. A temperatura em que ocorre a ebulição da água depende, ou não, da quantidade usada?

7. A temperatura em que se inicia a ebulição da mistura de água e glicerina depende da quantidade usada? Depende da proporção da mistura?

8. A água apresenta um único valor para o ponto de ebulição? E a mistura da água e glicerina?

\section{VI - Conclusões}

Neste experimento, você comparou o comportamento de dois líquidos incolores água e uma mistura de água e glicerina, quando aquecidos. O sistema constituído por uma única substância - água - apresentou uma temperatura definida durante a ebulição, enquanto para o sistema água e glicerina, uma mistura de duas substâncias, o processo de ebulição ocorreu numa faixa de temperatura. Além disso, na comparação do valor obtido, em seu estudo, para o ponto de ebulição da água, com os valores obtidos pelos outros colegas, você notou que estes valores eram muito próximos, isto é, iguais admitindo-se que as aparentes diferenças são devidas a erros experimentais. Considerando que a quantidade de água variou a cada grupo, você pôde dizer que o ponto de ebulição da água independe da quantidade de material. $\mathrm{Na}$ mistura, o ponto de ebulição não apresenta um único valor; ele varia com a mudança da proporção de água e glicerina da mistura, provocada pela evaporação da água: o ponto de ebulição de uma mistura não é constante. Já a água apresenta um único ponto de ebulição, independe da quantidade da amostra analisada: o ponto de ebulição da água é uma constante física. A Tabela II-1 apresenta os pontos de ebulição de algumas substâncias.

Tabela II-1: Pontos de Ebulição de algumas substâncias à pressão normal.

\begin{tabular}{|c|c|c|c|}
\hline Substância & $\frac{\text { Ponto de ebuliçắc }}{9} \mathcal{C}$ & Substância & $\frac{\text { Ponto de ebuliç: }}{\mathfrak{Q} C}$ \\
\hline Acetona & 56,2 & Clorofórmio & 61,74 \\
\hline Álcool etílico & 78,5 & Glicerina & $182^{20}$ \\
\hline Éter etílico & 34,51 & Nitrogênio & $-195,8$ \\
\hline Benzeno & 80,1 & Ferro & 3000 \\
\hline Metano & -164 & Alumínio & 2464 \\
\hline Álcool isopropílico & 82,4 & $\begin{array}{c}\text { Álcool } \\
\text { propílico }\end{array}$ & 97,4 \\
\hline
\end{tabular}


Considerando suas respostas às questões anteriores e a Tabela II.1, responda às questões que se seguem.

1. O ponto de ebulição é uma prioridade característica de uma substância? Explique sua resposta.

2. Como é possível diferenciar várias substâncias líquidas aparentemente iguais? Explique sua resposta.

3. Através do ponto de ebulição é possível diferenciar uma substância de uma mistura? Explique sua resposta.

4. Considerando suas conclusões neste experimento, defina substância.

5. Considerando suas conclusões neste experimento, defina mistura.

\section{VII- Exercícios}

1. A acetona, líquido incolor utilizado como solvente de algumas tintas e esmaltes, pode ser obtida através de uma reação do álcool isopropílico. Este álcool também é líquido e incolor. Como se pode ter certeza de que o produto obtido nessa reação seja realmente a acetona? Como saber se o produto é um líquido puro e não uma mistura?

2. Como é possível diferenciar água pura da água do mar filtrada sem experimentar o gosto?

3. Faça os esboços dos gráficos obtidos para o aquecimento de duas amostras de líquidos aparentemente idênticos, considerando os seguintes casos:
a) as duas amostras são do mesmo líquido puro;
b) as duas amostras são de líquidos puros diferentes;
c) uma amostra é de um líquido puro e a outra é de uma mistura.

4. Utilizando os dados da Tabela II.1, esboce um gráfico que represente a variação da temperatura com o tempo, durante o aquecimento de uma amostra de benzeno do estado líquido até a ebulição completa.

5. Provocou-se o aquecimento de um líquido desconhecido, medindo-se a temperatura do material em intervalos de tempo de 15 segundos, até que todo o material estivesse vaporizado. Os resultados obtidos estão organizados na tabela abaixo:

\begin{tabular}{|l|l|l|l|l|l|l|l|l|l|l|l|}
\hline Tempo(s) & 0 & 15 & 30 & 45 & 60 & 75 & 90 & 105 & 120 & 135 & 150 \\
\hline $\begin{array}{c}\text { Temperatura } \\
{ }^{\circ} \mathrm{C}\end{array}$ & 25 & 34 & 43 & 51 & 59 & 61 & 62 & 62 & 61 & 63 & 70 \\
\hline
\end{tabular}

a) A partir destes dados esboce o gráfico (temperatura $x$ tempo) numa folha de papel milimetrado.

b) O material deve ser uma substância ou uma mistura? Explique sua resposta.

c) Qual deve ser o estado físico do material após 1 minuto?

6. Consultando a tabela II.1, diga qual deveria ser, na sua opinião, o estado físico da acetona e do benzeno a $56,2^{\circ} \mathrm{C}$ e a $80,1^{\circ} \mathrm{C}$, respectivamente. 
VIII - Questões para discussão

1. Na Terra, uma das temperaturas mais baixas é observada no Pólo Norte (aproximadamente $-100{ }^{\circ} \mathrm{C}$ ). Pensando nisso, você acha que o ponto de ebulição do oxigênio deve ser menor ou maior que $50^{\circ} \mathrm{C}$ ? Explique sua resposta.

2. Que cuidados deveriam ser tomados no acondicionamento e transporte de líquidos de baixo ponto de ebulição?

3. É possível distinguir-se duas misturas de água e glicerina formadas por proporções diferentes destas substâncias? Como?

4. Existem misturas, chamadas de misturas azeotrópicas, que apresentam um único valor para o ponto de ebulição. Um exemplo é a mistura constituída por $96 \%$ e álcool etílico e $4 \%$ de água. Como você explica este fato?

\section{Guia experimental II-2}

Ponto de Fusão

I- Introdução

Como você viu no experimento anterior, o ponto de ebulição de uma substância é uma constante física, pois apresenta um único valor que depende apenas da substância e não da quantidade da mesma. Assim, o ponto de ebulição pode ser utilizado para identificação de uma substância.

No entanto, existem substâncias que possuem pontos de ebulição muito próximos. Por exemplo, o pontode ebulição do álcool isopropílico é $82,4^{\circ} \mathrm{C}$ e do álcool tercisobutílico é $82,2^{\circ} \mathrm{C}$ e ambas substâncias são líquidos incolores à temperatura ambiente. Neste caso, seria extremamente difícil a distinção destas duas substâncias apenas pelos seus pontos de ebulição. É necessário, portanto conhecer outras propriedades características destas substâncias para que se possa identificá-las com maior confiabilidade.

E, no caso de ser necessário identificar uma substância sólida? Seria prático determinar seu ponto de ebulição?

Através do gosto é possível distinguir dois sólidos como o sal e o açúcar. Mas, num laboratório, experimentar materiais é uma prática proibida! E como você poderia, por exemplo, saber que uma porção de ácido acetilsalisílico - principal constituinte da aspirina - está isenta de outros materiais que até poderiam ser nocivos à saúde? $\mathrm{E}$, ainda, como saber se aquele ácido, preparado à partir de uma reação química, é realmente o ácido acetilsalisílico?

Para responder a esta questão também é necessário conhecer outras propriedades físicas das substâncias. Uma das maneiras seria observar 0 comportamento destas substâncias sólidas quando submetidas ao aquecimento.

Geralmente, um sólido, quando aquecido, começa a se transformar em líquido ao alcançar uma determinada temperatura, isto é, começa a fundir: a temperatura na qual ocorre a fusão de um sólido e denominada ponto de fusão. Por outro lado, um líquido ao ser resfriado, transforma-se em sólido, ou seja, solidifica. A temperatura em que ocorre a solidificação de um líquido é denominada ponto de solidificação. 
Como estas propriedades físicas podem ser utilizadas para caracterizar uma substância sólida e diferenciá-la de uma mistura?

Para responder a esta questão você deverá realizar o experimento a seguir, onde analisará a variação da temperatura em função do tempo durante o aquecimento e a fusão ou resfriamento e a solidificação, de dois materiais diferentes. Através desta análise você vai ser capaz de:

- redefinir o que é uma substância;

- comparar o ponto de fusão e o ponto de solidificação de uma substância;

- verificar se o ponto de fusão é uma constante física;

- verificar se o ponto de fusão pode ser utilizado para identificar uma substância e distinguí-la de uma mistura.

II - Material Necessário

2 tubos de ensaio

1 termômetro de -10 a $110^{\circ} \mathrm{C}$

1 aro ou tripé

1 mufa

1 bico de Bunsen

1 tenaz

naftalina

água

\author{
1 béquer de $250 \mathrm{ml}$ \\ 1 suporte universal \\ 1 garra \\ 1 cronômetro ou relógio com marcador \\ de segundos \\ 1 tela de amianto \\ 1 almofariz e pistilo \\ Parafina
}

\section{Procedimento}

1. Trabalhe com segurança : Cuidado com as queimaduras, lembre-se de que o vidro quente tem o mesmo aspecto que o vidro frio. Se a bancada for de azulejo, não coloque materiais quentes diretamente sobre ela; coloque-os sobre uma tela de amianto.

2. Coloque água até aproximadamente $3 / 4$ do volume do béquer.

3. Triture algumas bolinhas de naftalina no almofariz e, a seguir , coloque a quantidade indicada pelo seu professor num dos tubos de ensaio.

4. Monte a aparelhagem conforme mostra a figura II.2.

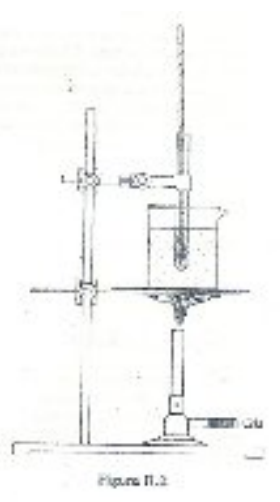

5. Após mergulhar na água do béquer o tubo de ensaio contendo o sólido e o termômetro, ligue o bico de Bunsen e inicie o aqueciemento. Se a água começar a ferver, desligue o bico de Bunsen.

6. Durante o aquecimento, agite o sólido com o termômetro, CUIDADOSAMENTE.

7. Anote a temperatura do sólido na tabela de dados a cada 15 segundos. Assinale, na tabela, a temperatura na qual se

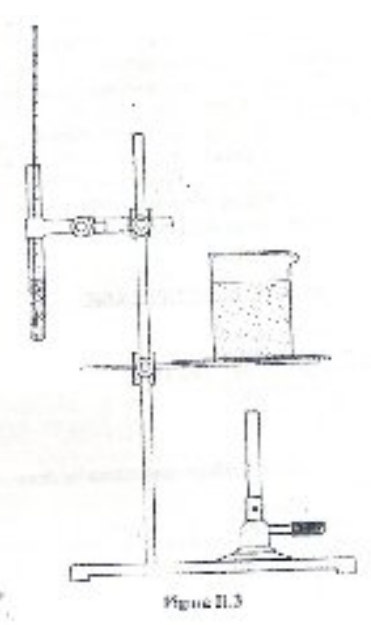


inicia e a temperatura na qual se completa a fusão do sólido.

8. Continue a anotar os dados até que a temperatura do material atinja cerca de $90^{\circ} \mathrm{C}$.

9. Retire, então, o tubo de ensaio da água conforme mostra a figura II.3 e comece imediatamente a anotar a temperatura do material a cada 15 segundos.

10. Durante o resfriamento agite o material com o termômetro, CUIDADOSAMENTE. Assinale a temperatura em que se inicia e a temperatura em que se completa a solidificação. Continue a anotar os dados até que a temperatura do material atinja cerca de $50^{\circ} \mathrm{C}$.

11. Repita todo o procedimento descrito utilizando uma amostra de parafina.

IV-Tabela de Dados

Reproduza em seu caderno, as tabelas a seguir com espaço suficiente para a anotação dos dados.

\section{V- Análise dos Dados}

1. Construa, num mesmo papel milimetrado, o gráfico que representa o aquecimento da naftalina e o que representa seu resfriamento, colocando a temperatura em ordenadas e o tempo em abscissas. Construa, também, os gráficos que representam o aquecimento e o resfriamento da parafina num outro papel milimetrado.

2. Indique o estado físico do material para cada ponto do gráfico.

3. Qual é a temperatura em que ocorre a solidificação da naftalina ? E da parafina? Verifique nos gráficos e compare com os resultados das outras equipes.

\section{Parafina}

Aquecimento

\begin{tabular}{|l|l|l|}
\hline Tempo & Temperatura & Observações \\
\hline & & \\
& & \\
& & \\
\hline
\end{tabular}

Resfriamento

\begin{tabular}{|c|c|c|}
\hline Tempo & Temperatura & Observações \\
\hline & & \\
& & \\
\hline
\end{tabular}




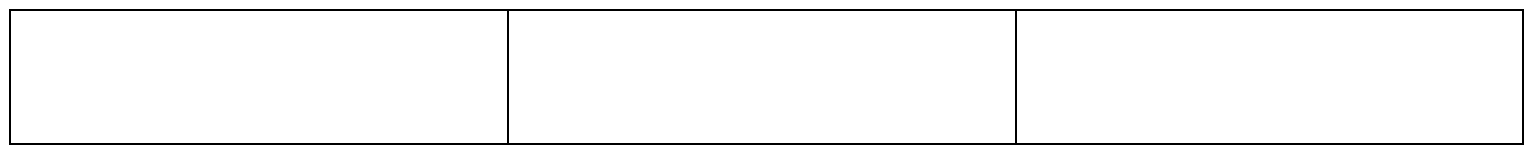

Naftalina

Aquecimento

\begin{tabular}{|l|l|l|}
\hline Tempo & Temperatura & Observações \\
\hline & & \\
& & \\
& & \\
\hline
\end{tabular}

\section{Resfriamento}

\begin{tabular}{|l|l|l|}
\hline Tempo & Temperatura & Observações \\
\hline & & \\
& & \\
& & \\
\hline
\end{tabular}

4. A naftalina apresenta um único valor para o ponto de solidificação? $E$ a parafina? Explique.

5. A temperatura de fusão da naftalina é próxima à sua temperatura de solidificação? Verifique os valores que você obteve. Pode-se admitir que estas temperaturas sejam iguais?

6. Qual é o ponto de fusão da naftalina?

7. A parafina apresenta um único valor para o ponto de fusão? Explique a sua resposta.

VI- Conclusões

Neste experimento você comparou o comportamento da naftalina e da parafina, dois sólidos igualmente brancos, frente ao aquecimento e ao resfriamento. No 
entanto, você pode observar que a parafina, que é uma mistura de várias substâncias, apresenta uma faixa de temperatura onde ocorre a fusão e uma faixa de temperatura correspondente à solidificação. Já a naftalina, que é constituída por uma única substância, o naftaleno, apresenta uma única temperatura de fusão e de solidificação. Além disso, ao comparar o ponto de fusão que você determinou com os valores obtidos pelos outros colegas para outras amostras de naftalina, você notou que esses valores são muito próximos .

1. Considerando que a quantidade de naftalina variou a cada grupo, você pode dizer que o ponto de fusão depende da quantidade de material?

2. Considerando que cada grupo de alunos utilizou naftalina de diferentes fabricantes, você pode dizer que o ponto de fusão depende da procedência da amostra?

3. Os valores do ponto de fusão e do ponto de solidificação são constantes físicas?

A tabela II.2 mostra os pontos de fusão e de solidificação de alguma substâncias

TABELA II-2

Pontos de fusão e de solidificação de algumas substâncias à pressão normal

\begin{tabular}{|c|c|c|}
\hline Substância & Ponto de Fusão $\left({ }^{\circ} \mathrm{C}\right)$ & Ponto de solidificação $\left({ }^{\circ} \mathrm{C}\right)$ \\
\hline Uréia & 135 & 135 \\
\hline Ferro & 1535 & 1535 \\
\hline Cloreto de sódio & 801 & 801 \\
\hline Açúcar & 185 & 185 \\
\hline Água & 0 & 0 \\
\hline Alumínio & 660,2 & 660,2 \\
\hline Tolueno & -95 & -95 \\
\hline
\end{tabular}

Analisando suas respostas anteriores e a tabela II.2, responda:

4. Para caracterizar uma substância é necessário determinar tanto o ponto de fusão como o ponto de solidificação? Explique sua resposta.

5. O ponto de fusão é uma propriedade característica de uma substância? Explique sua resposta.

6. Você poderia, através do ponto de fusão, diferenciar várias substâncias da mesma cor?

7. Como se pode distinguir uma substância sólida de uma mistura?

8. Considerando suas conclusões neste experimento e no experimento anterior defina substância.

9. Considerando suas conclusões neste experimento e no experimento anterior defina mistura . 
1. Se você realizar uma reação química para obter o ácido acetilsalisílico, como pode ter certeza de que se trata dele mesmo? Como você pode saber se está ou não puro?

2. Os gráficos abaixo, construídos na mesma escala, mostram a variação da temperatura com o tempo durante o aquecimento de cinco amostras de sólidos aparentemente idênticos.
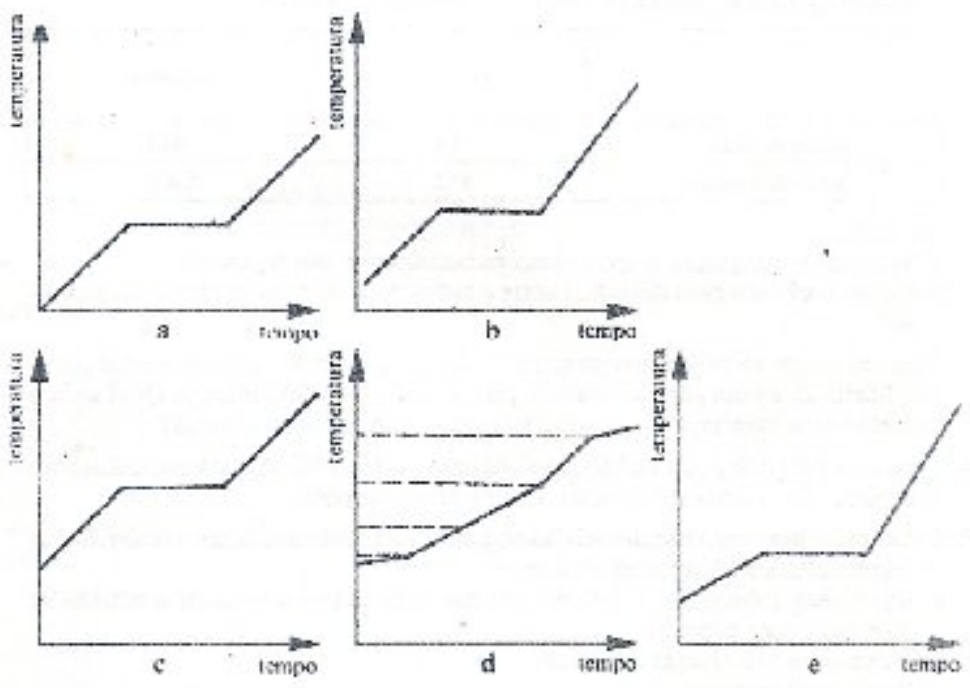

A partir da análise destes gráficos, responda e explique suas respostas:

a) quais das amostras são misturas?

b) Quais das amostras são substâncias?

c) Você pode dizer que há mais de uma amostra da mesma substância?

d) Você pode dizer em qual das amostras há maior quantidade de material?

e) Esboce gráficos que representem o resfriamento das amostras das substâncias.

3. Proponha um procedimento que possa ser empregado na identificação de um líquido altamente inflamável.

4. Mediu-se o ponto de fusão de dois sólidos brancos e puros. O ponto de fusão encontrado para um deles foi $45^{\circ} \mathrm{C}$ e, para outro, $44,5^{\circ} \mathrm{C}$. É possível identificálos apenas com estes dados?

5. Analise a tabela que se segue e responda à questão.

\begin{tabular}{|c|c|c|}
\hline Substância & Ponto de Fusão $\left({ }^{\circ} \mathrm{C}\right)$ & Ponto de Ebulição $\left({ }^{\circ} \mathrm{C}\right)$ \\
\hline Nitrogênio & $-209,86$ & $-195,8$ \\
\hline Bromo & $-7,2$ & 58,78 \\
\hline Metano & $-182,48$ & -164 \\
\hline Difenilcarbinol & 69 & 298 \\
\hline
\end{tabular}

A representação $298^{748}$ para o ponto de ebulição do difenilcarbinol significa que este ponto de ebulição (298) foi medido a uma pressão de $748 \mathrm{mmHg}$.

A temperatura ambiente $\left(25^{\circ} \mathrm{C}\right)$ quais destas substâncias são gases? Quais são líquidos? Quais são sólidos?

6. Dados os pontos de fusão e os pontos de ebulição de naftaleno e benzeno,

\begin{tabular}{|l|l|l|}
\hline & Benzeno & Naftaleno \\
\hline Ponto de fusão & 5,5 & 80,2 \\
\hline Ponto de ebulição & 80,1 & 218,0 \\
\hline
\end{tabular}


responda:

a) Em qual temperatura ambos, concomitantemente são líquidos?

b) Como você faria para distinguir entre o naftaleno e o benzeno, sem olhar 0 rótulo?

7. Aqueceu-se um sólido branco em um tubo de ensaio. Depois de algum tempo, houve a liberação de um gás e notou-se a presença de um sólido branco. Qual seria o procedimento para verificar se ocorreu reação química neste sistema?

8. Sabe-se que $5 \mathrm{ml}$ de ácido sulfúrico solidificaram a $10^{\circ} \mathrm{C}$. A que temperatura solidificarão $10 \mathrm{ml}$ desta substância? Justifique sua resposta.

9. Dois sólidos brancos, de aparência homogênea, foram aquecidos até a fusão. Esboce o gráficoque seria de se esperar se :

a) forem duas substâncias idênticas, mas das quais se tenha utilizado quantidades diferentes para o teste.

b) forem duas substâncias diferentes.

c) forem misturas.

10. Provocou-se o aquecimento de um sólido desconhecido, medindo-se a temperatura do material em intervalos de tempo de 30 segundos, até que todo o material estivesse fundido. Os resultados obtidos estão organizados na tabela seguinte:

\begin{tabular}{|l|l|l|l|l|l|l|l|l|l|l|}
\hline Tempo(s) & 0 & 30 & 60 & 90 & 120 & 150 & 180 & 210 & 240 & 270 \\
\hline Temperatura $^{\circ} \mathrm{C}$ & 25 & 34 & 43 & 51 & 59 & 65 & 68 & 69 & 73 & 80 \\
\hline
\end{tabular}

a) A partir destes dados, construa o gráfico (temperatura $X$ tempo) numa folha de papel milimetrado.

b) O material deve ser uma mistura ou uma substância? Explique.

c) Qual é o estado físico do material após 4, 5 minutos de aquecimento?

VIII - Questões para discussão

1. O ponto de fusão da glicerina é $17^{\circ} \mathrm{C}$. Qual é o estado físico desta substância no dia de hoje?

2. O ponto de fusão da amônia é $-77,7^{\circ} \mathrm{C}$. Num determinado ponto do Pólo Norte, onde a temperatura fosse $-80^{\circ} \mathrm{C}$, em que estado físico você encontraria esta substância?

3. Um estudante misturou dois sólidos num laboratório e notou uma mudança de cor. Como ele pode ter certeza de que tenha ocorrido uma reação química?

4. Por que Vodka não solidifica, mesmo na Sibéria?

5. Existem algumas misturas chamadas misturas eutéticas que apresentam temperatura constante durante a fusão, por exemplo, a liga metálica formada pela mistura de chumbo e arsênio. Como você explica este fato?

Guia Experimental II -3

Densidade

\section{I- Introdução}

O álcool anidro e o álcool hidratado são líquidos de mesmo aspecto e de mesmo odor. Uma propriedade utilizada para distinguir esses dois líquidos é a densidade. Além disso, conhecendo-se a densidade de uma amostra de álcool hidratado pode-se determinar a composição da amostra, ou seja, a quantidade de álcool e de água que constituem a mistura. 
Mas de que modo a determinação da densidade possibilita a caracterização de uma substância ? E de que maneira o conhecimento desta propriedade permite distinguir uma substância de uma mistura?

Através deste experimento você vai encontrar respostas para estas questões pois, ao final da atividade, você deverá ser capaz de :

- definir densidade

julgar se a densidade permite diferenciar uma substância de uma outra mistura.

\section{II- $\quad$ Material Necessário}

3 frascos pequenos e iguais

água

ácido sulfúrico

alumínio

1ovo
1 béquer de $400 \mathrm{ml}$ mercúrio

sal

ferro

III - Procedimento, Analise de dados e Conclusões

Parte A

1. Seu professor vai the indicar três frascos contendo volumes iguais de três substâncias líquidas: água, ácido sulfúrico e mercúrio. Segure cada um dos frascos com cuidado. O que você nota?

2. As massas contidas em volumes iguais destas substâncias são iguais? Justifique sua resposta.

3. Agora compare a massa de uma amostra de ferro e de uma amostra de alumínio aproximadamente de mesmo volume. Para isso segure cada uma delas numa mão. O que você nota?

4. As massas contidas em volumes iguais dessas substâncias são iguais? Justifique sua resposta.

Nesta atividade você comparou as massas de volume iguais de algumas substâncias. Assim, você pôde perceber que as massas de cada uma das substâncias que ocupam um mesmo volume são diferentes. Arelação entre a massa $(\mathrm{m})$ e o volume (V) de uma determinada substância é expressa matematicamente pela razão $\mathrm{m} / \mathrm{V}$. Esta razão é a densidade da substância. Em geral, a densidade é expressa $\mathrm{em} \mathrm{g} / \mathrm{cm}^{3}$. Assim a densidade indica a massa (em gramas) que ocupa um volume de $1 \mathrm{~cm}^{3}$

A tabela II.3 mostra a densidade de algumas substâncias.

Tabela II-3

Densidade de algumas substâncias à temperatura ambiente

\begin{tabular}{|c|c|}
\hline Substância & Densidade \\
\hline Mercúrio & 13,546 \\
\hline Ácido sulfúrico & 1,841 \\
\hline Água & 1,00 \\
\hline Ferro & 7,86 \\
\hline Alumínio & 2,702 \\
\hline Chumbo & 11,3 \\
\hline Cobre & 8,9 \\
\hline Ouro & 19,3 \\
\hline
\end{tabular}


5. Qual das substâncias acima apresenta maior densidade?

6. Se tivéssemos volumes iguais de ouro, cobre e chumbo qual apresentaria menor massa? Explique sua resposta.

7. Se tivéssemos massas iguais de ácido sulfúrico, mercúrio e água os volumes seriam iguais? Explique sua resposta.

8. A densidade de uma amostra de $10 \mathrm{~cm}^{3}$ de ferro é diferente da densidade de uma amostra de $5 \mathrm{~cm}^{3}$ de ferro? Explique sua resposta.

9. A densidade de uma amostra de $27 \mathrm{~g}$ de alumínio é diferente da densidade de uma amostra de $270 \mathrm{~g}$ de alumínio?Explique sua resposta.

10. A densidade de uma substância é uma constante física?

11. A densidade pode ser utilizada para caracterizar uma substância ? Explique sua resposta.
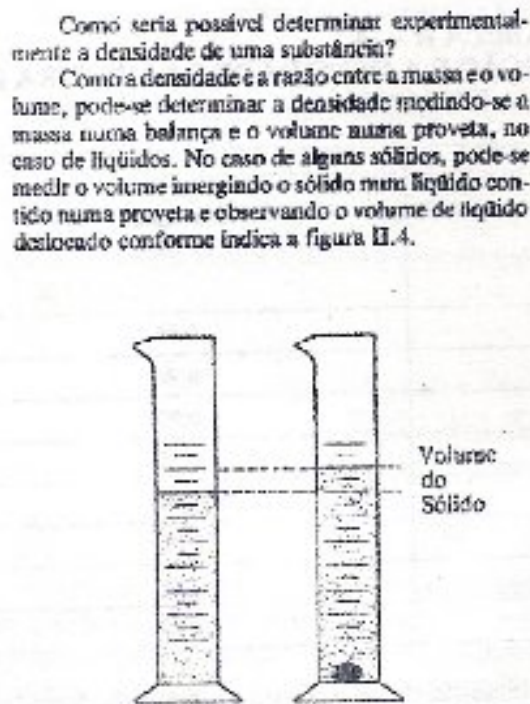

\section{Yoluse:}

Sóliso

Figura Il,4

Mesiča de vetume de un aólido arrante do

volume de lísilido deslocado.

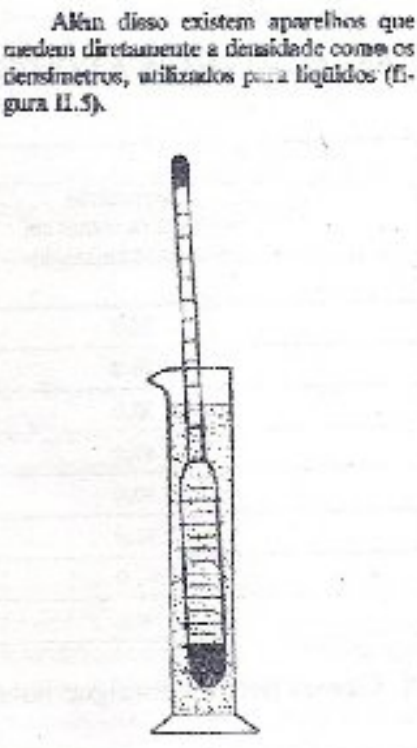

Figura if. 5

Odensienerre merie diretamente a densidade des tiglidios.

\section{Parte B}

Neste experimento utilizaremos um ovo para comparar densidades de líquidos.

1. Coloque um ovo num béquer com água e observe.

2. Adicione 2 colheres de sal à água contida no béquer e agite. $\mathrm{O}$ que você nota?

3. Vá adicionando mais sal aos poucos. O que acontece com o ovo?

4. Você pode dizer que a densidade do líquido permanece a mesma com a adição do sal?

5. Diferentes misturas de água e sal apresentam a mesma densidade? Explique sua resposta.

Assim, como no caso da mistura água e sal , a mistura água e álcool (álcool hidratado) também não apresenta uma densidade característica. A densidade da mistura varia com a composição, isto é, com as quantidades de álcool e água presentes na amostra. No entanto, para uma determinada composição fixa têm-se uma densidade 
determinada. Conhecendo-se a densidade de uma mistura é possível saber a sua composição?

Também outras misturas como as ligas metálicas, que são mistura de metais, apresentam densidades diferentes dependendo da composição.

A tabela II. 4. mostra a densidade de misturas de álcool etílico (etanol) e água , de diversas composições.

Tabela II -4

Relação entre a composição e a densidade da mistura de água e etanol

\begin{tabular}{|c|c|}
\hline $\begin{array}{c}\text { Composição (volume de etanol em 100 } \\
\mathrm{cm}^{3} \text { de mistura) }\end{array}$ & Densidade $\left(\mathrm{g} / \mathrm{cm}^{3}\right)$ \\
\hline 10,0 & 0,99 \\
\hline 20,0 & 0,98 \\
\hline 30,0 & 0,97 \\
\hline 40,0 & 0,95 \\
\hline 50,0 & 0,93 \\
\hline 92,0 & 0,83 \\
\hline 96,0 & 0,81 \\
\hline 99,0 & 0,80 \\
\hline
\end{tabular}

6- Como é possível distinguir uma substância de uma outra mistura através da densidade?

\section{Exercícios}

1. Considerando a tabela :

\begin{tabular}{|l|l|l|l|}
\hline Substância & Ponto de Fusão & Ponto de Ebulição & Densidade \\
\hline Álcool etílico & 117,3 & 78,5 & 0,7893 \\
\hline Acetona & 95,35 & 56,2 & 0,7899 \\
\hline Ácido sulfúrico & 10 & 340 & 1,834 \\
\hline Benzeno & 5,5 & 80,1 & 0,87865 \\
\hline Tolueno & -95 & 110,6 & 0,8669 \\
\hline $\begin{array}{l}\text { Trinitrotolueno } \\
\text { (TNT) }\end{array}$ & 82 & Explode a 240 & 1,654 \\
\hline Sulfato de cobre II & 110 & 150 & 2,284 \\
\hline Ferro & 1535 & 3000 & 7,86 \\
\hline Alumínio & 660,2 & 2467 & 2,702 \\
\hline Naftaleno & 80,55 & 218 & 1,0253 \\
\hline
\end{tabular}

a) Quais substâncias podem ser encontradas no estado sólido na temperatura de $80^{\circ} \mathrm{C}$ ?

b) Quais substâncias certamente são encontradas no estado líquido na temperatura de $110^{\circ} \mathrm{C}$ ?

c) Como você faria, estando no laboratório, para distinguir entre dois frascos sem rótulos, sabendo que em um deles há naftaleno e, em outro, há benzeno?

d) Onde há maior massa, em um litro de ácido sulfúrico ou e dois litros de tolueno? Explique sua resposta.

e) Como você faria, estando no laboratório, para distinguir entre dois frascos sem rótulos, sabendo que em um deles há benzeno $\mathrm{e}$, no 
outro, há tolueno e sabendo também, que ambas substâncias são inflamáveis em temperaturas elevadas?

\section{V- Questões para Discussão}

1. Como você explicaria o funcionamento dos aparelhos de controle de qualidade do álcool hidratado existentes nos postos de distribuição de combustíveis?

2. A densidade do ferro é muito maior do que a da água. Por que um navio de ferro não afunda? 


\section{QUESTÕES}

Anexo 7

1) Escreva, com suas palavras, o que você entende por transformação química.

2) Dentre as inúmeras transformações que você observa no seu dia a dia, existe alguma que você considera uma transformação química? Deixe claro os critérios que você utilizou para fazer sua escolha.

3) Uma pessoa que gostaria de obter dados sobre as transformações que se passam em diferentes sistemas realizou alguns ensaios, descritos a seguir:

a.Quando duas soluções incolores foram misturadas observou-se o aparecimento de um precipitado branco.

b. Ao se aquecerem dois líqüidos, notou-se o desprendimento de gases.

c.Um líquido foi adicionado a um sólido e observou-se o desprendimento de um gás. esverdeada

d.Um líquido verde foi misturado a um liquido amarelo e obteve-se uma solução

e.Um sólido branco, de ponto de fusão $145-146{ }^{\circ} \mathrm{C}$ foi aquecido, obtendo-se um sólido branco de ponto de fusão $144-150{ }^{\circ} \mathrm{C}$.

Em quais desses ensaios houve evidência de formação de um novo material? Justifique claramente sua resposta. 
4) (ENEM 2006) As características dos vinhos dependem do grau de maturação das uvas nas parreiras porque as concentrações de diversas substancias da composição das uvas variam a medida que as uvas vão amadurecendo. O gráfico a seguir mostra a variação da concentração de três substancias presentes em uvas, em função do tempo. O teor alcoólico do vinho deve-se a fermentação dos açúcares do suco da uva. Por sua vez, a acidez do vinho produzido e proporcional à concentração dos ácidos tartárico e málico.

Considerando-se as diferentes características desejadas, as uvas podem ser colhidas:

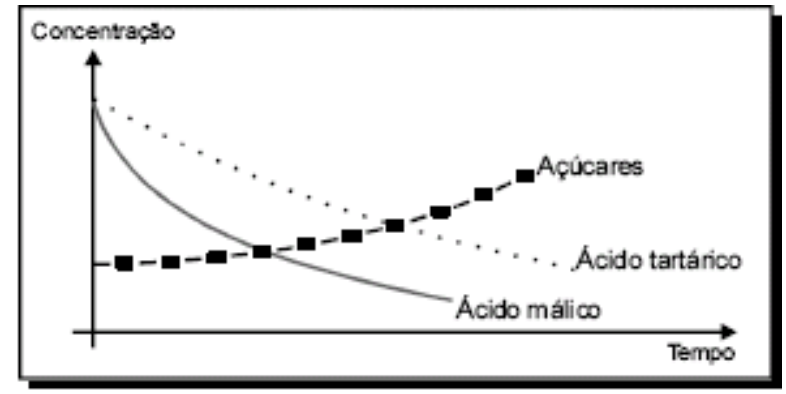

a) mais cedo, para a obtenção de vinhos menos ácidos e menos alcoólicos.

b) mais cedo, para a obtenção de vinhos mais ácidos e mais alcoólicos.

c) mais tarde, para a obtenção de vinhos mais alcoólicos e menos ácidos.

d) mais cedo e ser fermentadas por mais tempo, para a obtenção de vinhos mais alcoólicos.

e) mais tarde e ser fermentadas por menos tempo, para a obtenção de vinhos menos alcoólicos.

6) Ao nível do mar, a água entra em ebulição a $100^{\circ} \mathrm{C}$. Na medida em que vai aumentando a altitude a temperatura de ebulição decresce aproximadamente $3^{\circ} \mathrm{C}$ a cada quilômetro. Numa cidade que esteja a $8,5 \mathrm{~km}$ acima do nível do mar, qual será a temperatura de ebulição da água? Escreva, resumidamente, o raciocínio que você utilizou para responder a essa questão.

7) Por que, ao aumentar a altitude, a temperatura de ebulição da água diminui? 
8) Alguns corpos bóiam na água e outros não. Delimite alguns dos fatores que influenciam na flutuação dos corpos. Como você explicaria esse fato para uma criança de dez anos?

9) Como você abordaria o tema transformações para alunos das séries iniciais?

10) Elabore um plano de aula sobre o tema transformações para alunos da série onde você atua. 


\section{Anexo 8}

Professor A

Escola B

Tempo 46'32"

176 Entrevistador: Vera, você leciona há quanto tempo?

177 Professor A: Sou dessa escola mesmo. Eu comecei tem vinte anos. Eu já estou recebendo a minha sexta parte (risos). Vinte anos e alguns meses para tirar a minha licença. Vinte anos...

178 Entrevistador:Sempre nessa escola?

179 Professor A: Sempre nessa escola.

180 Entrevistador:Ah, tá.

181 Entrevistador:E qual a sua formação profissional?

182 Professor A: É assim: eu me formei no antigo Magistério,né? De quando eu comecei a dar aula até dez anos atrás, era só o magistério que eu tinha que eu trouxe lá do Maranhão, que eu me formei, no Nordeste. Aí incomodava não ter uma faculdade. Só que eu não queria fazer pedagogia, aí eu fui fazer história. Então eu tenho curso superior de história. Além do Magistério, né? Eu não fiz pedagogia. Eu só fiz Magistério. E na hora de complementar eu sempre tive paixão por história. Eu gosto mesmo. Então eu falei. Na hora de complementar complementar. Sempre quis fazer uma faculdade de História. Poderia ter feito Pedagogia também. Mas preferi fazer o curso de História.

183Entrevistador:E assim em relação ao ensino de ciências, né? Quando você fez o Magistério, você teve assim, aulas práticas de ciências.

184 Professor A: Não puramente decorativa. Era a época do ensino por questionários, né.? Tinha lá o ponto como a gente falava e não se observava, não tinha observação, era só o questionário. Era ponto e questionário. Não tinha nada de prático assim.

185 Entrevistador: Isso teve algum consequência de ensinar ciências para as crianças?

186 Professor A: Eu me incomodava de ser repetitiva assim. Eu percebo que teve repercussão sim. No começo era copiar também.Depois que eu fui refletindo e eu mudei de postura mas sinto que refletia sim. Ficava sempre em segundo plano ciências assim, né? Não que eu não gostasse da matéria, mas era muito monótono dar ciências. Cansativo eu não digo. Era monótono era chato. Não cansativo. Abre o livro, leia o outro parágrafo, o outro parágrafo, o outro parágrafo, como eu aprendi. Agora 
vamos responder as perguntas porque também o material pedagógico era assim também. O ponto e as perguntas, o ponto e as perguntas. Eu reproduzia a forma de ensinar como eu aprendi porque o livro era igual como e aprendi. Tem mudada de uns tempos para cá.Repercutiu sim. Então retransmitia como me transmitiram.

187 Entrevistador: Há quanto tempo você utiliza experimentos nas aulas de ciências?

188 ProfessorA: Eu sou "fucenta". Eu fuço. Como eu leio. Eu fui procurando livros e caiu nas minhas mãos uns livros de experiência da biblioteca. Aí fui lendo esses livros e fui vendo a experiências como é que era. Esses livros não eram didáticos. Eram paradidáticos. Através desses livros fui vendo as experiências. E mais ultimamente os livros didáticos trazem orientação de como fazer experimentos, o que não tinha antigamente. Isto é de uns cinco ou seis anos para cá. Foram leituras que eu fiz.

189 Entrevistador:Foram somente leituras?

190 Professor A: Foram leituras. Como eu te falei, sou fucenta. Foram leituras de paradidáticos que eu fui procurando, que foram caindo nas minhas mãos assim. Aí eu fui relacionando conteúdo do livro com esses livros que eu tinha lido e e fui cumprindo as experiência. Eu experimentava não dava certo .Fazia com eles não dava certo, fazia aí a gente fazia de novo. Foram os livros paradidáticos. Não foram os livros didáticos deles não. Foi mais pesquisa. Mas fui eu mesma. Não foi curso.Nunca fiz curso voltado para ciências pelo Estado. Nunca fiz.

191 Entrevistador:Nunca fez nenhum curso assim?

192 Professor A: Curso de ciências, voltado ali para relatório, nunca. O estado a leste não proporcionam.

193 Entrevistador:Não proporcionam.?

194 Professor A: Não. Esta oportunidade não.

195Entrevistador:Sobre o curso que nós fizemos no ano passado? Você tem algo assim a falar?

196 Professor A: Como assim sobre o curso de ciências? Eu não tenho nenhum curso com você. Lembra que eu fui para o Recife e meu filho ficou noivo?

197 Entrevistador: Sim, mas até onde você fez.

198 Professor A: Ah, sim. Até o gráfico. Quando a gente tava fazendo lá o trabalho do gráfico do tanto que demorou para esquentar a vela, a parafina, lembra?

199 Entrevistador:Lembro. 
200 Professor A: Assim,o que eu aprendi no curso, é isso que você está perguntando?

201 Entrevistador:Assim, ele trouxe alguma coisa para você?

202 Professor A: Ah trouxe, trouxe. Na questão mesmo até de usar mais o laboratório, por exemplo da escola que tem umas coisas eu nem sabia que tinha lá. Se bem que eu fuço no laboratório, né. Naquele material todo.....eu continuo não indo tá? Continuo não indo...

203 Entrevistador:Mas a e na sua prática depois do curso?

204 Professor A: Tem o mapa conceitual que eu não sabia fazer, né dentro de ciências e aí levei para as outras matérias. Não faço mapa conceitual não só com a questão da água, né. Só com a música do Guilherme Arantes. As palavras depois relacionando a água com outras disciplinas. Ai como eu aprendi a fazer mapa conceitual. levo para outras disciplinas : faço com história, faço com geografia. A questão de fazer a prática também, né e a experiência....que é possível dar aula de ciências no concreto, assim. Foi a única experiência que eu tive, viu?. Eu nunca tive um curso assim não.

205Entrevistador:Nunca teve nesses vinte anos de magistério?

206 Professor A: Não. Eu tive cursos voltados para Português, Produção de Textos, Matemática...mas para área de humanas não tive. Não fiz. Fazem vinte anos. E não que eu nunca fui atrás, que eu me negasse a ir.. Eu sempre fui atrás. É que nunca chegou para mim.

207 Entrevistador: Esses cursos nunca chegaram para você?

208 Professor A: Como é que eles chamam esses cursos. É para você ir lá e ser..um multiplicador. Não, teve um .Sobre o Procel. Eu lembro que eu fui lá na leste era sobre economia de energia naquela época do apagão. Então o governo tava lá para ensinar você como economizar energia. Esse do PROCEL mas foi uma coisa bem vaga de umas horinhas.

209 Entrevistador:Foi um dia só?

210 Professor A: Só. Você tinha que vir para cá para ser o multiplicador. Passei o material para o coordenador. O coordenador não deu andamento para agendar. Ficou por isso mesmo. Mas na sala de aula eu fiz.

211 Entrevistador:Na sala de aula você chegou a fazer?

212 Professor A: O que eu aprendi lá fiz na sala de aula.

213Entrevistador:Você falou para mim que você é uma professora fucenta, que você aprendeu a fazer os experimentos.... como você percebe o momento em que o aluno 
está fazendo os experimentos, assim?

214 Professor A: Como eu percebo? Como eu percebo como o aluno fica? Ah eu acho que fica mais ligado, se interessa mais. E não é m.....mérito meu não, sabe. Acho que você lança um desafio para ele ele quer ver o resultado. Ele quer ver onde vai chegar.Eu percebo isso: eles se sentem desafiados e querem ver o resultado do desafio, eu acho assim.

215Entrevistador:E em relação à escrita você percebe alguma mudança, nos relatórios?

216 Professor $A$ : Os primeiros relatórios que eu faço quando eu começo os experimentos assim, eu faço junto com eles na lousa. Eu vou substituindo as palavras, o que nós podemos usar agora, a seqüência, como se deu a sequenciação dos fatos, né? e a finalização. Depois eu deixo por conta deles. Eles vão fazendo lá os relatos deles . E aí eu ensino a sistematizar, a coerência, etc. Eu acho que dá certo. Eu gosto quando eles fazem o relatório, dá certo. Ou seja em ciências ou geografia, que eles tem que ver o mapa, alguma coisa, eles tem que depois sistematizar,né? a coerência..... ta certo?. Eles tem que sistematizar, tá certo? Lógico que aos poucos eles vão estruturando o texto. Vão fazendo a estrutura.

217 Entrevistador:Como foi a escolha do livro didático de ciências neste ano?

218 Professor A: É tão rápido, né Mari Inez? Para a gente fazer a escolha. ... eles levam os livros lá e lá e colocam trocentos livros na sua frente. Aí você vai olhando. Esse é bom. Esse não é bom,,, mas muito vaga essa escolha. Depois tem colegas que ainda querem o livros com o questionário bem grande que é para o aluno responder bastante perguntas. E não aqueles que tem as experiências ou livros que demandam mais análise. Então não tem tempo para analisar o livro. E nem sempre o que a gente pede é o que vem. Eu nem me lembro qual que eu pedi, qual que escolhemos. O governo manda o que tiver.

219 Entrevistador:E a respeito do livro que veio neste ano? Qual a sua impressão dele?

220 Professor A: Ah,Ele é reflexivo, viu. Ele questiona muito as questões ambientais. Ele foca muito as questões ambientais de ciências. Esta questão de enchente de reciclagem do corpo humano. Ele não muda. Eu percebo que ele não muda a sequencia dos conteúdos. E a célula, o corpo humano, depois reciclagem, poluição. $A$ gente sabe, né, reciclagem, poluição...vem na até a sequência. Só que aparece mais reflexão, tem muitas perguntas pessoais para o aluno estar se colocando, se questionando.... isso eu acho bacana.

221 Entrevistador:Esse livro didático possui experimentos?

222 Professor A: Possui. 
223 Entrevistador:Você chegou a realizá-los?

224 Professor A: Sim. Eu cheguei a realizá-los. Outro que eu vou realizar agora é da eletricidade. A gente vai entrar no tema da eletricidade, no assunto da eletricidade e nós vamos fazer o circuito elétrico. Ele está propondo toda a atividade prática, do pulmão do sistema respiratório, do sistema.... a maioria dele escreveu, das estações de tratamento. mas poderia ter mais. Acho que podia ter mais.

\section{Entrevistador:Poderia ter mais experiência?}

226 Professor A: Poderia ter mais experiência. Porque é o que eu te falo. Assim,como ele enfoca esses assuntos assim, de educação agora. Ele são mais voltados eles, eu é que digo eles estão mais voltado para a questão ambiental de ciências. Bem mesmo na questão ambiental, né? : doenças transmissíveis, dengue. essa epidemia que está acontecendo a gente sabe que está acontecendo não traz. A questão ambiental é só aonde ele é mais focado né. Só. Então da questão que nós estávamos trabalhando. A questão que eu estava trabalhando. A questão que a gente trabalhou.Os seres pluricelulares, as bactérias. Não é isto não é ciência voltado para a questão ambiental. A ciência está voltado para a questão ambiental.

227 Entrevistador: Em relação ao conteúdo em relação à terceira série como você julga?É proprio para a faixa etária ou não é?

228 Professor $A$ : Olha, eles conseguem absorver sim. Dá para absorver na faixa etária deles, dá para absorver. Não é vago, dada a leitura que já realizei. Não dá para absorver sim. Mas a questão do meio ambiente, assim é que parece muito fora da realidade deles. A questão da Amazônia, do desmatamento. Isso é muito longe deles muito longe deles....é muito longe.Então, essa questão é difícil levá-los lá para uma floresta, né? A questão ambiental aqui é outra, né. É uma outra questão ambiental. É uma outra consciência que tem que se criar. Eu acho que isso é um pouco fora.

229 Entrevistador:No seu ponto de vista como você abordaria essa questão ambiental com as crianças?

230 Professor A: Eu acho que inserir no contexto em que ele vive. Numa cidade, numa metrópole, né ? Eu penso assim. O cidadão que está lá. Como ele vai se preocupar aqui? Quais são as coisas mais imediatas com as coisas aqui, né, que você tem que trabalhar? A cidadania, na questão da geografia, a cidadania. A questão da enchente, do quintal do vizinho, a poluição sonora, a poluição visual, tudo isso é tratado. Mas acho que é isso que a gente tem que focar mais assim com eles. Que é coisas do diaa-dia. Eu percebo que a coisa fica só na campanha. Não tem a coisa prática. Eles não transferem. 
232 Professor A: É. Olha só a campanha do lixo, eles não participam. Eles jogam o papel para perturbar.

233 Entrevistador: E porque você acha que isso acontece?

234 Professor A: É porque só aqui que ele é ensinado. Não tem uma transferência disso. Ele não consegue transferir o comportamento diário. Lá na família ninguém cobra isso. A escola é o único lugar que transfere esses valores para ele. Como ele não é cobrado lá fora, ele não consegue. O mesmo aluno que sabe aqui que ele aprendeu, que sabe que ele tem que reciclar o lixo, é o primeiro a jogar papel e chutar lata feito bola. É difícil fazê-lo transpor do discurso do caderno para a prática. Eu acho que a dificuldade é porque no ambiente eles vivem não são cobrados.

235 Entrevistador: Você diz assim em casa?

236 Professor A: É em casa. Também tem o ponto que eles vêem os outros fazendo muitas vezes e eles fazem também. Eu penso assim, tá? Quando eles jogam papelzinho...gente não é só para ficar no caderno é para vocês falarem, fazer com os outros, observem o outro, cobrem o outro. Você não sentiu isso? Eu sinto que não há uma transferência do discurso para a prática. Só fica no discurso, só fica na leitura e não tem transferência. Mas estudar meio ambiente é bacana, tudo. Cuidar do micro para o macro. Do meu aqui, da escola, de casa da rua....tem que se ver como cidadão atuante. Agora a parte biológica da ciência que eu acho que o livro não enfoca tanto, sabe fica naqueles conceitos assim de estudar.

237 Entrevistador: Como que teria que ser esta parte biológica para você?

238 Professor A: Lembra quanto eu te falei da transmissão de doenças, alguns livros dão ênfase nisso mas os deles não. o tratamento da água, a importância disso, a importância da higiene, a importância do hábito de escolher bem os alimentos, a parte o funcionamento. Eu acho que fica muito nomeando os órgãos, nomeando, nomeando, tá no nome, classificando. Eu acho que agente tinha que fazer uma coisa mais voltada, assim para que eles percebam. Eu não sei como fazer.

239 Entrevistador: Você não sabe como fazer?

240 Professor A: O que eu sei é o que testo lá. Vamos fazer alguma coisa. Vamos por uma maçã para apodrecer, para ver os fungos. Vamos fazer iogurte, vinagre. São essas coisas assim pinceladas.

241 Entrevistador: E a respeito daquele modelo anatômico (torso humano)que você tem ali? Como que você trabalhou?

242 Professor A: Ah, aquele modelo anatômico foi um sucesso, viu? Eu deixei eles manusearem. Primeiro eu pedi para que eles escrevessem o que tinha dentro do 
corpo, né?E só saiu as tripas como eles falam. As tripas.Tripa e coração (risos). Quando eles viram a "Eva" e desmontaram toda ela, ficou mais fácil. Mas ainda sim a gente consegue nomear doenças e tal, os cuidados com o próprio corpo. Eles gostaram. Foi mais fácil trabalhar com aquilo lá. Mas aí eu falei para eles. Isso aqui tá duro. O da gente é todo molinho por causa dos tecidos. Deixei a Eva livre para eles montarem e desmontarem. Eu percebi que quem mais monta e desmonta é a minha aluna especial, a Gabriele. Ela adora ela. Quando eles deixam tudo espalhado, eu peço para a Gabriele montar e ela vai lá e monta direitinho. Eu acho que é bom. Grava, fixa. Sai do abstrato vai para o concreto. Ela não sai mais daqui.Eu não deixo mais ela no laborátório não. Porque lá vai ficar só enchendo de poeira e coberta.Achei que foi bom.

243 Professor A: O que mais?

244 Entrevistador: Eu quero agradecer a entrevista. Você foi um amor.Você não sabe o quanto você está colaborando comigo. E eu quero convdá-la para o dia da defesa da minha dissertação. Eu gostaria que você tivesse presente.

245 Professor A: Imagina. Eu é que tenho mais que agradecer porque quando você veio, qualquer pessoa assim, eu quero aprender com as pessoas também. Porque como eu não tive assim, uma formação pedagógica, não fiz pedagogia. Eu sou PEB I. Se perguntar assim: você é especialista em quê? Nós damos todas as matérias. Temos que estudar muito. Acho que o professor que se especializa como eu me especializei. Embora não seja tão especializada porque eu não peguei nenhum gênero da História na época. Nem contemporânea, nem a moderna (eu adoro aquilo). Porque uma pessoa que trabalha de quinta em diante que se especializa numa disciplina, ele vai mais fundo. Então eu não. Eu sinto assim uma necessidade de aprender com todos e você é formada em no caso está se especializando em ciências. O que eu puder aprender com com você. Eu fui fazer o seu curso que era fora do meu horário para eu aprender, para eu ensinar melhor, para eu ter um retorno melhor, porque eu não sou da área. $\mathrm{O}$ professor do ensino fundamental precisa estudar muito mais, tem que saber de todas as áreas. E ciências que eu aprendi dessa forma conceitual. Vem você de biologia, vem a outra de física e a outra de química, quero aprender porque eu tenho as lacunas. A gente nunca vai preencher todas mas eu quero aprender com você. O que você puder trazer para a gente experimentar aqui nesse laboratório. A classe da gente é um laboratório, né?

246 Entrevistador: É um laboratório.

247 Professor A: Porque é aqui onde a gente erra, a gente acerta, onde a gente aprende. Eu aprendi muito com você e a sua colega (Michele). Com quem quer que venha eu quero aprender. E eu sinto uma vontade de transmitir depois. As vezes tem resistência mas a gente passa alguma coisa. Muito obrigada você também. (risos). Você veio aqui, 
que bom ter dado aqui. Nem deu para terminar o curso direitinho com você....

248 Entrevistador: O que você modificaria naquele curso que eu fiz?

249 Professor A: Ai meu Deus.....eu não fui até o fim. Porque é mais voltado assim para o ginásio, né? Ou pro Ensino Médio. É voltado para o Ensino Médio? Eu aprendi alguma coisa, a trabalhar os mapas, a prática. Mas modificar não tenho muito para lhe dizer. Não tenho informação para te falar.

250 Entrevistador: E em relação ao tempo?

251 Professor A: A gente teve uma hora né para fazer?

252 Entrevistador: É uma hora. Você acha que era suficiente?

253 Professor A: Eu acho que era. Dependendo da periodicidade. Duas vezes por semana uma hora. Da para desenvolver o trabalho em uma hora. Como não? Dá sim. Uma hora eu acho que dá para desenvolver. Você deixava tudo organizadinho. Quando a gente chegava já estava tudo montado, né? Todas as coisas em cima da mesa, da bancada, estava tudo montado.Então como já tinha as apostilas prontas e tudo organizado, em uma hora dá para fazer muita coisa. Porque? Porque tem organização. Você já deixava tudo organizado. Enfim, não posso te dizer o que modificaria. Não tenho gabarito para isso, para te dizer o que mudaria.

254 Entrevistador: Se houvesse um segundo curso, o que você gostaria de ver no segundo curso?

255 Professor A: Como assim na Física, nas Ciências Biológicas, Biologia, como assim? Entrevistador: Em ciências de um modo geral.

256 Professor A: Ah, pois é. Não é que eu gosto de curso apostilado não. Mas eu gostaria que fosse elaborado um curso que tivesse conteúdos assim para.. voltados para levar o aluno a refletir, com estratégias de abordagem.... estratégias de abordagem dos assuntos assim, voltados para a estratégia para despertá-los para a ciência, fazer experimentos, fazer depois fazer relatórios. Eu quero isso..., mais assim adequados para a idade deles. Nada assim muito rebuscado. Que a gente possa lançar mão de coisas de casa para ver e fazer. Assim...eu me lembro que tinha uma aluna na quarta série e que foi para escola particular. Um dia ela me ligou ela falou assim para mim "professora sabe o que é ? é que aqui a professora não acredita que eu fiz tal experiência, que eu fiz tal experiência. Aquela sala era tão boa que as experiências foram evoluindo. Eu saí completamente do livro didático. Aí chegou a hora das provas bimestrais e eu só tinha experiência. Eu só dei experiência. Daí eu tive que criar as provas né? Eu acho que um curso assim que a gente possa ...

257 Professor A: Você sentiu falta do livro didático de ciências, depois que você só deu 
experiências?Quando você caiu em si que só deu experiências? Eu só li os paradidáticos que eu fui atrás. Eu li livros de uma coleção. Eu não senti falta não. Não mesmo. Eu fiz várias experiências. Trabalhamos com o grupo de alimentos. Fizemos a experiência com o iodo para ver o que era amido e o que não era amido. Fizemos da densidade da água, lá do ovo. E depois fazíamos o relatório. Fizemos o relatório do oxigênio, da vela, fizemos muitas experiências. O livro didático não me fez falta não. Mas fazia falta no caderno só. E nos relatórios. Tem muita gente que fica cobrando "o que tem no caderno?". Sabe que isto dá medo às vezes? Dá a impressão que é só você que destoa dos outros?Trabalhar com experiência é bom. Mas acho que eles precisam da leitura também. Eles vão fazer o relatório, mas eles precisam de leitura. Para entender e compreender. Acho que só com experiência.....não gosto de nada assim com só, só....É bom trabalhar experiência, trabalhar relatório, trabalhar escrita, trabalhar leitura, mas, um texto informativo também é bom. Eu não abomino eu não desconjuro livro didático. Eu gosto, mas só ele também é muito pouco. Agora aumentou a grade de ciências? É a mesma, né? A grade de ciências é a mesma. São três ou duas? História aumentou.

258 Entrevistador: Eu não sei. Se aumentou uma vai diminuir outra. Espero que não seja ciências.

259 Professor A: Gente, uma coisa que eu sinto falta e posso lhe dizer. E não é aqui porque os meus alunos são pequenos e não dá para trabalhar isso. Mas eu acho que deveria ter isso. Você perguntou do curso e na minha cabeça veio isso: um curso voltado para toda essa revolução que tá acontecendo na genética, na biogenética. Gente, quando a você vê os experimentos. Você trabalha todas as mutações essas transformações na genética. Tudo isso eu não vejo ser trabalhado de quinta a oitava série. Eu acho muito denso esse conteúdo para ser trabalhado de primeira à quarta. Eu vejo assim. Eu vejo que temos aí a tecnologia, a biotecnologia , os professores hoje em dia e não sei as faculdades, mas eu não sou da área de ciências, mas sou da área de história.....gente tá acontecendo uma revolução muito grande na ciência : a biotecnologia, essa parte que é da....como é que chama?Da biologia, as mutações genéticas, as coisas...transgênicos. Tudo isso tá faltando isso para o professor! O mundo tá mudando e essa partre das ciências não tá mudando.

260 Entrevistador: Essa parte você diz do ensino?

261 Professor A: O ensino não acompanha a velocidade das mudanças ! Você vai me falar, eu tenho certeza! Não tenho, suponho...peraí. Eu não tou aqui para te ensinar....mas puxa! O que se está discutindo atualmente sobre as células tronco, toda essa parte de experimentos da EMBRAPA, experimentos na área da revolução da genética e tudo? Isso é atual. Essa coisa que tá acontecendo, os experimentos atômicos.... e eu não vejo isso voltado para a formação dos alunos e professores. Fica lá com os doutores, 
fica lá com os professores doutores. As pesquisas que não chegam até aqui. Então vamos falar da célula tronco, do embrião, do geneticista. Da EMBRAPA que está experimentando. De todas as outras formas de produção de alimentos, da mandioca vitaminada, entendeu? Isso não chega nas escolas. Pode até ser que chegue nas redes particulares, né e tudo que investe na formação do professor mesmo mas ainda fica naquele mesmo conteúdo, sabe?conhecimentos são estáticos aqui na escola....os conhecimentos são estáticos..... né? Eu tava com a "Eva" aqui e veio uma professora da sétima para buscar a "Eva" porque ela precisava dar uma aula de ciências também: sistema isso, sistema aquilo, sistema aquilo outro. Então se repete o conteúdo. Ah mas agora é mais aprofundado, o aluno vai ter outros olhos. Gente mas essas coisas que estão acontecendo? Eu acho: A biotecnologia, essa questão da da genética. tudo isso precisa vir para dentro da escola. Tem professor que não sabe e é da área, sabe? É porque é amplo o campo é imenso mas tem certas coisas que não dá para você ignorar . Eu acho que não dá Mari Inez. Em História eu não posso ignorar e dizer o que aprendi na faculdade já tá bom. Se eu não me informar, se eu não continuar estudando.Temos que ver que o mundo mudou, que a história mudou.Ela é dinâmica. A Ciência é dinâmica. E eu vejo que ela é estática dentro da escola. Os conhecimentos são estáticos, né quando se fala....antigamente se falava na clonagem, né? Mas isso é muito pouco que vem para a escola ....o próprio professor eu não entendo que ele fica nomeando os órgãos. Os nomes, os nomes, os nomes. Ele dá a mesma matéria de quinta ao colegial. Se você pegar o livro é a mesma coisa. São sistemas, a mesma coisa. Fica repetindo, repetindo....Escuta e o mundo? Não entra em discussão, o professor não lê e o estado não oferece nenhum curso. Eu nunca tive nada disso. Depois que você terminar o mestrado você vai continuar de primeira a quarta?

262 Entrevistador: Eu pretendo continuar.

263Professor A: Porque a escola de primeira a quarta precisa de professor bem preparado. É por isso que preciso aprender contigo que é da área. Se vier um de história eu quero fazer curso. Eu quero aprender e eu quero que traga coisas novas e não o que eu já sei. E não o arroz com feijão, o be-a-bá. Ah, mas tem que ter coisas novas? O mundo é dinâmico e temos que ver as coisas novas que estão acontecendo, os conflitos. É difícil mas eu queria ver. O professor tem que ler e acabar com a repetição dos conteúdos. Vai repetindo, repetindo até...... Aí Mari Inez quando chega o ENEM, quado chega essas provas para eles entrarem na faculdade, os assuntos são aqueles que eles não viram na escola. Só sabem os professores doutores, os mestres, os pesquisadores, eles sabem. Aí eles vão e preparam aquelas provas bonitas, né?

\section{Entrevistador: A Prova Brasil?}

265Professor A: Não aquelas que eles preparam quando vão para a faculdade. 


\section{Entrevistador: É o ENEM?}

266 Professor A: É o ENEM, mas tem outras que eles medem o índice. Umas provas que eles vão fazendo. Tem vários mecanismos. Aí você vê que prova bonita. A mãe de um aluno foi lá fazer e entregou. Ela deixou de fazer. Ela não consegue ler o texto. Tudo da atualidade! A parte de ciências referia-se sobre a genética, falava da biodiversidade, e isso não foi ensinado na escola. Os livros tratam disso? Tem muito livro bom. Mas o professor nessa de ter liberdade. Ele vai dar aquilo que sabe e não aquilo que precisa estudar ainda para dar. Por causa da liberdade, sabe. Ah eu vou dar a mesma aula de dois anos atrás. Ele vai dar o que ele domina, senão fica inseguro. Precisa dar curso sim. Mas precisa fazer o professor estudar. Você estudou pra caramba, né? Eu também estudei muito. E não é porque eu quero ganhar um pouco a mais . Pra mim não, Mari Inez. Ah é que você poderia dar aula na escola particular que você iria ganhar mais. Não é por aí não. Eu quero trabalhar aqui mesmo. Eu não quero mudar escola particular. Eu queria mudar é isso aqui. Eu falo para os meus alunos. A mesma aula que dou para vocês é a aula que daria na escola particular. Talvez com mais recursos audiovisuais, tivesse outras coisas para enriquecer. Eu não mudaria de comportamento. Eu queria outros cursos sim, mas tem, que aprender com vocês que vem para cá. Eu penso assim. Não sei...se você gostou... eu falo demais.

267 Entrevistador: Obrigada pela sua atenção mais uma vez...

268 Professor A: Depois o que a gente discutiu aqui, você me dá o retorno para ver se eu não tou errada?

269 Entrevistador: Então, eu vou te dar no dia da dissertação. Por isso que eu quero que você vá na dissertação.

270 Professor A: Será que eu tou pensando certo? Eu penso dessa maneira em virtude de muitas leituras que eu fiz. Mas será que eu tô indo na contramão?Será que é por aí mesmo? Será que o que eu falo tem lógica, ou não?Eu queria saber ...

82 Entrevistador: Mercedes, você leciona há quanto tempo?

83 Professora B: 20 anos.

84 Entrevistador: 20 anos...e qual a sua formação profissional?

85 Professora B: O quê?

86 Entrevistador: Formação Profissional...

87 Professora B: Primeiro Magistério, depois fiz faculdade de Pedagogia, três habilitações O.E. em Administração Escolar e Supervisão Escolar.Depois fiz Direito e agora em 2007 fiz Pós Graduação em Direito Civil.

88 Entrevistador: Qual o perfil da sua sala que você pegou neste ano? 
89 Professora B: (suspira fundo) Muito difícil, aluno com diversos problemas, diversos problemas não só pessoais mas também familiares que trazem assim, refletem no ambiente escolar eh... com vários tipos de... comportamentos né? que precisavam ser orientados, ser trabalhados, ter acompanhamento psicológico e profissional e não só acompanhamento na sala de aula com a professora. Mas devido ao grande número de alunos, tá muito difícil trabalhar,e com os problemas que a clientela trazmais difícil ainda porque.. aluno sim como... com muita dificuldade....dificuldade de aprendizagem e dificuldade assim de uma ...aceitação para ele mesmo, sabe? Eu acho que teve ... não sei acho que alguma coisa, algum problema que ele tem né?Porque as vezes é a falta de displicência, saber obedecer, então muitas coisas faltando na vida deles, melhorar, né ? Eu senti assim com muita responsabilidade, ter que se desdobrar muito e às vezes sem conseguir muita coisa porque os problemas são demais. Não só assim problemas sociais, problemas psicológicos, problemas .......inaudível.....estão sendo criandos pela avós, criados assim com muita necessidade que os professores, da participação da mãe para a gente somar, né? O problema é que se elas não vêm à escola, acabam né....atrapalhando também as outras crianças. $E$ além dessas crianças que estavam aqui havia muitas crianças com um comportamento fóra de série. Eu nem poderia imaginar que ela estaria naquele meio.....mas...inaudível. $E$ também crianças com desajustamento. Alunod de 15 anos na sala de aula junto com criança de nove, com criança de 10 . Muito difícil.

90 Entrevistador: Com todas essas dificuldades que você teve,você chegou a trabalhar com eles ciências?

91 ProfessorB: Ciênicas.....ah trabalhei muito com ciênciascom eles. Em ciênicas trabalho mais com pesquisa. Com observação, com trabalho também feito em sala de aula, trabalho feito fora da sala de aula, pesquisa na Internet. Pedi para que eles observassem a natureza.

92 Entrevistador: Quais foram os temas que você abordou em ciênicas?

93 ProfessorB: Em ciências, por exemplo, corpo humano, por exemplo sobre a água, a importância da água no nosso planeta, que a água representa a vida, a escassez da água , que no futuro a briga no mundo será pela água porque em muitos países do mundo irá faltar água e provavelmente esses países virão buscar água no Brasil, porque o Brasil será a nova fonte, porque o Brasil é o país que tem maior volume de água. Trabalhei muito com Trabalhei muito com o processo da economia da água. Como é que lava o carro. Usando o balde ao invés de utilizar mangueira. Orientando as crianças para conversar com os pais a respeito de como lavar louça, é juntar toda a louça, ensaboar e depois lavar de uma vez para não gastar muita água. E também juntar roupa. Não ficar lavando uma peça de cada vez, juntar a roupa. As calçadas e os quintais, antes de lavar com a mangueira que desperdiça água, lavar com o balde. Varrer a calçada e o quintal antes e usar o balde para lavar. Quando for lavar o quintal , 
fazê-lo pela manhã ou no finalzinho da tarde porque é nesse horário que se consome menos água.

94 Entrevistador: Certo.Você fez o curso de Ciências no ano passado?

95 Professora B: Onde que foi? Ah fiz ...aquele do laboratório...fiz.

96 Entrevistador: E qual foi a sua impressão daquele curso?

97 Professora B: A impressão daquele curso geralmente é o que falta na nossa sala de aula. Eu acho que na nossa sala de aula, eu acho que as ciências não está sendo ensinada de acordo como deve ser ensinada. Com a prática e também baseada em pesquisas, baseada na observação que eu tenho certeza que tem muita gente que não ensina ciências. Não é por má vontade, é por falta de orientação. É por falta de material, é por falta de espaço. Que nem aqui na escola, nós não temos um laboratório. É um espaço que está faltando aqui na escola. A ciência não tá tendo seu lugar privilegiado por exemplo no ambiente escolarProfessora B: A impressão que tive daquele curso é o que realmente falta na nossa sala de aula. Eu acho que a Ciência não está sendo ensinada como deve ser ensinada com a prática e também baseada em pesquisas, baseada na observação porque eu tenho certeza porque eu tenho certeza que tem muita gente...a ciência não é neutra.....falta material, falta espaço, que nem aqui na escola, nós não temos um laboratório, isto está faltando aqui na escola. A ciência não está tendo seu lugar privilegiado na escola. Porque assim não vai adiantar nada. Porque nós temos que procurar mudar. Mudar , trabalhar com a observação com a experiência, trabalhar com pesquisa porque o nosso futuro vai depender da pesquisa. Então a gente não pode pegar Ciências e só dar aula teórica, nós temos eh...como é que se diz ...nós temos que por em prática, praticar não só para ter aula teórica em sala de aula, nós temos que ter conhecimento para passar para outras pessoas, para as amiguinhas, porque senão não tem sentido esse conhecimento, vai ficar guardado só para nós. Nós temos que aprender e passar e não segurar esse conhecimento.

98 Entrevistador: A respeito do ensino de ciências...como é que eles viram aqui? Você chegou a realizar atividades práticas com eles? Como é que você percebe eles quando tem que fazer uma pesquisa, têm que fazer um trabalho de observação?

99 Professora B: Pelo tipo de criança que tenho aqui que eu acho que são mais crianças hiperativas, elas se deram até bem com a Ciência porque parece que combina um pouco com o seu comportamento assim. Sabe a gente olha e parece que há uma certa ligação. A hiperatividade significa movimento como por exemplo com o movimento dos planetas, o nosso movimento. A Terra está sempre em movimento, nosso corpo também está. $O$ nosso coração, ele não para de bater. Significa que nós estamos sempre em movimento e a ciência também. Ela está sempre caminhando. O que eu achei engraçado é que quando eu falei das pesquisas eles ficaram interessadíssimos em querer fazer. Não só pesquisa nesta área. Pesquisa em todos os campos do 
conhecimento. Assuntos assim que despertam interesse. Agora sim Ciências eu bati muito o assunto da água, o assunto da dengue, os cuidados com a água, a questão da água e a saúde, porque a água está muito ligada com a nossa saúde porque dependendo do tipo de água que você toma, você fica doente e se tratar a água e procurar cuidar, você vai ter mais saúde.

100 Pesquisador: Durante o magistério, quando você estava fazendo magistério, Você teve aula prática de ciências? Você teve Metodologia de Ensino de Ciências, você teve Didática?

101 Professora B: No último ano de Magistério eu tive aula prática nas escolas. Meu último ano de magistério foram quarenta dias de estágio. Nesses quarenta dias a gente não ia para a escola, a gente preparava aula e ia pro colégio mesmo. Depois desses quarenta dias é que você voltava a ter aula.

102 Pesquisador: E nesses quarenta dias você chegou a ter aula prática de ciências? Chegou a dar aula prática de ciências?

103 Professora B: Eu cheguei a fazer um trabalho que para mim era muito especial. Eu estava muito empolgada, me formando, era a minha primeira formatura. Era a minha primeira formatura e eu estudava num colégio particular e para mim era uma honra. Uma honra eu apresentar naquela escola um bom trabalho aos alunos. Não era para eu me aparecer, mas pessoalmente, para mim o trabalho tinha que ser bom, tinha que ser excelente para mim mesma. $O$ trabalho que eu tinha que apresentar eu não sabia desenhar, aí tinha uma vizinha e ela me ensinou a desenhar e me ensinou a usar o esquadro. Eu nunca tive aula de desenho e não sabia usar o compasso. Quando eu casei o meu marido cursava exatas e ele desenhava para mim. Mas eu não queria que ele fizesse as coisas para mim. Os outros fazendo eu não aprendo foi quando essa vizinha me ensinou a fazer o desenho e aí eu me senti muito feliz por fazer um desenho assim. Eu fiz um desenho da parte de ciências acho que sobre plantas e aí quando eu cheguei lá eu fiz um desenho naquele tempo, eu não lembro qual foi o tema do desenho eu acho que foi plantas. Aí quando eu cheguei lá e apresentei lá a aula para as crianças, eles já me conheciam como professora de matemática porque eu já dava aula de matemática, né. Eu já dava aula de Matemática particular porque desde a quinta série. Na sétima série eu dava aula para a sexta e na oitava eu dava aula para a sétima e nisso as crianças tinham um carinho tão grande por mim porque eu até fiquei surpresa. A professora de Didática assistindo a aula disse para mim. "Este é um cartaz digno de ser apresentado. " Quando eu ouvi isso eu não acreditei, eu não acreditei. E aquela frase de amor me transformou de tal maneira...As vezes a não sabemos todas as coisas, mas se você acreditar, você pode realizar aquilo que você faz do seu melhor . Cada vez mais procurando fazer o melhor. O melhor do que eu pudesse apresentar. Não para mostrar para ninguém mas para a minha satisfação, que eu quero é que as crianças aprendam. 
104 Entrevistador: E nesses 20 anos que você leciona, sempre foi aqui em São Paulo?

105 Professora B: Sempre aqui em São Paulo.

106 Entrevistador: E nesses 20 anos que você leciona, você teve algum curso de Ciências?

107 Professora B: Não. Ciências eu nunca tive nenhum curso. Mas todos os dias, todos os dias eu leio jornal. Leio livros que fundamentam. Quando chega na parte de Ciências ou em uma parte que me é interessante, eu destaco aquele assunto e paro. E olho e anoto.Eu sou uma pessoa que anoto os assuntos. Eu não leio nada que seja importante e que deixe de anotar. Eu anoto, procuro fazer pesquisa, procuro olhar. Por exemplo o que mais me chamou atenção sobre a água foi a quantidade de água nesse planeta, depois eu fiz um trabalho, uma pesquisa sobre aquecimento global. As experiências, porque o aquecimento global está acontecendo. Eu eu não vejo ninguém discutir sobre aquecimento global. Eu acho isso importantíssimo. Nós temos que falar de assuntos que são importantes para a nossa vida que faça parte da nossa vida.Nós temos que falar para as crianças, nós temos que interagir, nós temos que falar para eles. Eu acho que tem que ser assim.

108 Entrevistador: Você chegou a participar da escolha do livro didático?

109 Professora B: Participei. Participei da escolha do livro didático.

110 Entrevistador: E como foi essa escolha do livro didático?

111 Professora B: O que eu achei da escolha...os livros já estavam prontos, já préescolhidos para o professor olhar. E ...não tinha nada para o professor fazer. Já estava tudo pronto. Eu acho que todos tinham que olhar e ver qual livro que tivesse assim mais aceitação para as professoras lecionarem no ano seguinte. A minha opção acabou sendo essa. Que eu não gostei. Nós gostamos de mudar de assunto também. Não só seguir aquilo que está lá pronto. Eu acho que cada professor deveria escolher o livro que mais gostasse.

112 Entrevistador: E o que você achou do livro de ciências?

113 Professora B: Esse livro deixou muito a desejar. Teve muitos assuntos não muito bem explicados. Por exemplo o livro de matemática.

114 Entrevistador: Não. O livro de ciências.

115 Professora B: O livro de ciências está muito teórico. Eu acho que deveria ser um livro mais baseado na reflexão. Mas não só para ler. Era para colocar o aluno para pensar. Eu não quero um livro que eu vá tirar xerox e passar para o aluno.Por exemplo sobre o corpo humano. Eu acho que o aluno é que tem que completar quais são as partes do corpo humano. Porque se você der um trabalho só pronto, só pronto. A criança acostuma com aquilo que está pronto. O trabalho tem que ser mais para a criança refletir, para pensar. Para a construção desse conhecimento. Porque aí tem um objetivo, uma aprendizagem diferente. Porque ela está construindo o seu próprio 
conhecimento.

116 Entrevistador: E me diz uma coisa.. Se você tivesse um outro curso de ciências, como é que você gostaria que fosse?

117 Professora B: Eu gostaria que tivesse laboratório, que tivesse aulas fora do horário de aula para ensinarmos os alunos a plantarem, para nós ensinarmos os alunos a pesquisarem. Por exemplo outras aulas de observação da natureza. Ensinar as crianças a cuidar dos animais. O respeito. A criança aprende a respeitar muito o ser humano a partir do momento que ela aprende a respeitar os animais. Porque esse carinho, esse respeito. Porque se ela tiver um gatinho em casa ela aprende a respeitar esse gatinho. Apreciar a natureza. Nós estamos preparando a criança para o respeito com a natureza e com nossa vida. $E$ isto não vai ser bom somente para a criança em particular, mas também para os professores se a criança tiver esse respeito pela natureza. É a partir daí que nos vamos começar a falar sobre aquecimento global, que é o aquecimento da Terra e que por isso que a Terra está ficando doente. E as pessoas só tiram e tiram e não cuida. Uma falta de respeito com os nossos vegetais, nossa flora, nossa fauna. Então nós precisamos ser pessoas mais conscientes e responsáveis com o meio ambiente. O meio onde vivemos. Porque no futuro as nossas crianças netos e bisnetos, vai ficar difícil.

118Entrevistador: Em algum momento você sentiu necessidade de um apoio nas suas aulas de ciências. Algum aluno que ficasse sem resposta?

119 Professor B: Não. Nesse ponto não porque é como eu falei para você. Eu sou uma pessoa que estuda sem ninguém falar nada. Eu estudo assim para satisfação e interesse meu. O que eu senti em sala de aula é que tivesse um diretor, que tivesse uma pessoa que me ajudasse. Nós iamos precisar de uma ajuda. Porque com essas salas lotadas de crianças sem assistencia psicológicas. Fica difícil. Porque fica tudo sob minha responsabilidade. A ciências precisa. Está precisando muito aqui na nossa escola. Porque ciência é vida. Mais até que Matemática. Porque matemática são números. E uma pena que não temos processores que estimulem esses alunos a serem pesquisadores. Para as crianças estudarem e passarem esse conhecimento.

\section{Professor B}

Escola B

Tempo: 3'48"

271 Entrevistador: Há quanto tempo você leciona? 
272 Professor B: Eu leciono há vinte anos.

273 Entrevistador: Você sempre trabalhou com primeira série?

274 Professor B: Não. Trabalhei seis anos. O restante em outras séries.

275 Entrevistador: Com várias séries de primeira à quarta?

276 Professor B: Isso.

277 Entrevistador: Nesse ano como foi a classe que você pegou. Qual o perfil da classe?

278 Professor B: Eu senti meia....você sabe. Eu não pude trabalhar como eu trabalho porque eles são muito faltosos. Tem dia que eu tenho 16, 20, 21. Eu senti dificuldade com isso. A minha sala é muito faltosa. Ainda tem alunos que são multirepetentes por falta. É desgastante.

279 Entrevistador: É um trabalho desgastante...

280 Professor B: Bastante, você vê que o trabalho não rendeu, não é. Eu leciono isso hoje, faltaram quatro. Quando é amanhã faltam outros cinco. Assim é complicado, né?

281 Entrevistador:O que você trabalhou em ciências com eles?

282 Professor B:Plantas, animais, tipos de solos e mais uma outra coisa que não me lembro agora. Eles fizeram observação do feijão,tipos de terra, etc...

283 Entrevistador: Você usou livro didático?

284 Professor B: Porque só tem o nosso. Eles não tem.

285 Entrevistador: Aquele curso do ano passado o que ele trouxe você?

286 Professor B: Ele trouxe a questão da importância da experiência, mas eu acho assim.

Eu acho que aquilo é legal mais para trabalhar com uma terceira ou quarta série. Ele é mais útil para terceira e quarta série. Porque na primeira e segunda série eles são muito novinhos para trabalhar aquilo que trabalhamos.

287 Entrevistador: O que você mudaria naquele curso.

288 Professor B: Eu não mudaria nada.Eu só gostaria que ele estivesse mais voltado para a primeira série. Eu leciono para a pré-escola de manhã e para a primeira série à tarde. E eles são imaturos. Eles vem para nós com o que? Seis anos.

289 Entrevistador: Se tiver um segundo curso, como você gostaria que fosse?

290 Professor B: Eu gostaria que fosse mais prático. Porque o teórico a gente já tem. Algo mais ligado a eles. 
291 Entrevistador: Ligado à faixa etária?

292 Professor B: À faixa etária.

293 Entrevistador: Neste caso você gostaria de ter um curso de ciências voltado para crianças da pré- escola e da primeira série?

294 Professor B: Exato. Ou uma coisa, tipo assim: que fosse ligado à primeira à quarta série, mas que fosse atendesse a qualquer faixa etária, entendeu?

295 Entrevistador: Durante o seu curso de magistério, você fez algum curso ligado à metodologia do ensino de ciências?

296 Professor B: Não ligado diretamente a ciências, não. Eu tive metodologia mas não ligado à ciências. Você só tem teoria no magistério. Você não vê prática. É chegar jogar o conteúdo e acabou. A gente sofre quando pega a sala de aula.

297 Entrevistador: Qual a sua formação?

298 Professor B: Eu fiz magistério e letras.:

Professor C

Escola B

Tempo: 8' 22"

299 Entrevistador: Professora, há quanto tempo você leciona para as séries iniciais ?

300 Professor C: Eu leciono há vinte e sete anos.

301 Entrevistador: Qual a sua formação profissional?

302 Professor C: Eu fiz magistério, pedagogia ,história, e administração.

303 Entrevistador: Como foi essa sala esse ano para você?

304 Professor C: A sala está dividida assim. Tem alguns alunos que têm dificuldade de aprendizagem e tem outros que estão com menos dificuldade. Está bem heterogênea essa turma e tenho aqueles que tinha maior dificuldade, conseguiram uma melhora, um desenvolvimento mais na parte assim da criticidade, do desenvolvimento intelectual é bem ativa.

305 Entrevistador: Como que foi a escolha do livro didático assim?

306 Professor C: Os exemplares foram expostos aqui na escola e junto com a professora nós analisamos e entramos num consenso assim das opções.

307 Entrevistador: O livro de ciências que eles utilizam apresenta parte experimental? 308 Professora Apresenta. Traz algumas experiências sim. 
309 Entrevistador: E como que você avalia esse livro de ciências que eles têm?

310 Professora: Olha esse livro ele é bom porque ele não é aquele livro que tem questões diretas. É um livro que precisa estar lendo e pensando para executar as atividades. Não é nada assim, como se diz decorativo assim em que a reposta estão explicitas no texto.

311 Entrevistador: Você chegou a realizar as atividades experimentais?

312 Não todas. Nós fizemos algumas. Umas com células, outras.... o corpo humano e o seu desenvolvimento e do meio ambiente também.

313 Entrevistador: Em relação ao curso do ano passado, como você avalia o curso de formação?

314 Professor C: Para mim no caso, eu achei muito interessante. O que você trabalhou com a gente algumas expectativas e gerou alguns conteúdos eram bem assim como podemos dizer praticamente desconhecido. Você sabe que esta matéria é um pouco (risos)... é trabalhosa. Foi dada uma base do que é a química realmente. As experiências foram muito boas, só que eu não tive como aplicar tudo, entendeu?

315Entrevistador :Você chegou a aplicar alguma experiência?

316 Professor C: Você diz a experiência do curso aqui? Acho que foi uma só que eu apliquei.

317 Agora eu não me lembro direito porque foi logo no início do ano. Foi logo no início do ano...eh não tou lembrada qual é. .....porque eu não quis pegar o material que a gente usou do laboratório.

318 Entrevistador: E durante a sua formação você teve aulas práticas de ciências? Ou metodologia de ensino de ciências?

319 Professor C: Não na formação do curso....na formação mesmo.......

320 Entrevistador: Do magistério?

321 Professor C: Não . É realmente uma coisa que deixa a desejar. Ainda quando eu fiz, há vinte e sete anos atrás não tinha nada específico.

322 Entrevistador: E isso faz falta para você em algum momento?

323 Professor C: Ah sim . Porque se você tiver uma capacitação bem mais elaborada, você tem segurança para trabalhar. Muitas vezes você não trabalha porque não tem segurança naquilo que você vai fazer. Aí de repente você tem medo de acontecer alguma coisa.... eu acho que realmente é muito proveitoso sim. As experiências que eu tive nessa parte foi com você.

324 Entrevistador: E nesses vinte e sete anos de magistério aconteceu de algum aluno fazer uma pergunta para você e você não conseguir explicar? 
325 Professor C: Não, não porque geralmente a gente já é direcionado.....geralmente naquilo que você domina o conteúdo, né?

326 (grande pausa de silêncio)

327 Entrevistador: Se tivesse outro curso na escola, como é que você gostaria que fosse?

328 Professora: Bom eu gostaria que fosse assim: em cima das expectativas e das propostas da escola, estar trabalhando dentro da nossa proposta.

329 Entrevistador: Em relação à parte experimental que você realizou, você notou interesse dos alunos?

330 Professor C: Ah, eles ficam bem mais interessados, embora eu fuja dessa coisa de copista. Eu explico muito para eles, tem muito diálogo. Tem muita troca de idéias....eles questionam muito. Eu gosto de realizar aulas bastante diversificadas e dialogadas.

331 Entrevistador: Eles chegaram a fazer relatório dos experimentos?

332 Professor C: Do que eu fiz eles fizeram.

333 Entrevistador: E em relação à escrita do relatório, o que você notou?

334 Professor C: Eu notei que as idéias ficam mais explicitas no relatório, mas precisam de algumas correções que a gente precisa fazer com eles, né? Erros ortográficos que é normal, né?

335 Entrevistador: Mas a coerência do texto, como que você viu?

336 Professor C: Ah sim a coerência sim, só a coesão que não, né? Não foi assim totalmente $100 \%$ mas dentro do entendimento deles, da fala deles, foi boa...

Professora D

\section{Escola A}

120 Entevistador: Marta, você leciona há quanto tempo?

121 Professora D: Há vinte e três anos.

122Entrevistador: Qual a sua formação?

123 Professora D: Tenho magistério, tenho Pedagogia e tenho cursos de aperfeiçoamento em alfabetização.Inclusive o Letra e Vida.

124 Entrevistador: Durante a sua formação em Magistério de primeira a quarta série,que era o antigo normal, você teve algum curso, ou alguma disciplina relacionada ao ensino de ciências.

125 Professora D: Não. Não, eu tive só a matéria e era só.

126 Entrevistador: Só.

127 Entrevistador: Não teve didática em ensino de ciências, nem metodologia em ensino de 
ciências?

128 Professora D: Não. O meu era voltado para alfabetização, era formação mesmo.

Quando você ia fazer o estágio, tinha três professores para observar a regência, que ficavam no fundo da sala assistindo a tua regência.Um professor não era formado assim como agora....faz supletivo e o que vai fazer? Vai fazer Magistério e aí vai dar aula. Que condições são essas? Se a pessoa nem está alfabetizada e como ela vai alfabetizar? A pessoa está procurando um emprego não está procurando o que ela gosta de fazer, porque Magistério é sa-cer-dó-cio.Não é para procurar emprego. Se fosse para procurar emprego ganhava muito mais. Tem professor que não está aí porque gosta. Está procurando emprego. Então vá procurar emprego que ganha muito mais.

129 Entrevisador: Em algum momento você sentiu falta de não ter um curso mais voltado para ciências?

130 Professor D: Eu senti não só falta de uma orientação não só em ciências mas também em história e geografia. Agora eu procuro fazer o que? Eu continuo estudando, estudando, estudando, me virando e fazendo cursos. Eu fiz cursos de ciênicas para eu poder trabalhar. Então eu faço articulação com as disciplinas.

131 Entrevistador: Esses cursos de Ciências que você fez foi promovido pela Rede Estadual de Ensino?

132 Professor D: Esses cursos foram promovidos pela Rede Estadual de Ensino e pela Folha de São Paulo.

133 Entrevistador: Faz muito tempo?

134 Professor D: O da Folha de São Paulo foi em 87. 87.

135Entrevistador: E esse do Estado em Ciências?

136 Professor D: Esse do Estado foi em 95...94 ou 95.Quando era, quando era a décima terceira delegacia.

137 Entrevistador: Ah, no tempo da décima terceira.

138 Professor D: É, no tempo da décima terceira.Eu me lembro que nós fizemos ate umas experiencias do ar, sabe. De como funcionava e como era composto o ar. Esses negócios aí. Foi muito bom.

139 Entrevistador: Foi só aquilo.

140 Professor D. Foi só aquilo. Ciências na escola, você que devia de dar conta,né? Eu não sei muita coisa, a gente sabe na prática, o dia a dia. A gente procura sempre estar se aprimorando, né Mari Inez. Mas que a gente recebe informação e orientação não. É mais de alfabetização. O Letra e vida por exemplo.

141 Entrevistador: No Letra e Vida não aparece nada relacionado a ciências? 
142 Professor D: Não. Só relacionado a alfabetização mesmo. Só letramento. Não tinha nada que me empolgasse, não. Aliás tudo que eu tinha feito lá já tinha feito com o Dalmo Dalari, Lino de Macedo, Fernando Becker, Emilia Ferreiro. Eu fui lá só para confirmar que eu estava trabalhando direito. Ciências é muito difícil. Ciências, História e Geografia eles só fazem curso para os professore de quinta em diante. Para o PEB I de primeira a quarta é muito difícil.Você fica só com a teoria. Aliás, alguns ficam com a teoria que procuram ler e saber lógico. Hoje eles fizeram um cartaz para orientar as pessoas sobre como se conserva o meio ambiente e eu estava ensinando eles a fazerem uma propaganda. Agora a única orientação que eu tive foi naqueles HTPCs que você deu. Experiência concreta.

143Entrevistador: Na nossa escola você acha que dá para fazer experiência.

144 Professor D: Eu acho que dá para fazer com plantas. Com coisas do nosso dia-adia.Mas nada que me chamasse a atenção de orientar o professor a trabalhar.

145 Entrevistador: Você chegou a trabalhar algum experimento em sala de aula?

146 Professor D: Não. Eu trabalhei no ano passado. Fiz a experiência da água e do óleo. Porque o óleo não mistura com a água. Eu fiz tudo isso aí. Eu não fiz mais porque eu tinha que alfabetizar.

147 Entrevistador: Qual é o perfil dessa sala que você pegou neste ano?

148 Professor D: $50 \%$ está alfabetizado.

149Entrevistador: Na terceira série.

150 Professor D: E eu tenho 5 inclusões aqui. Pode gravar isso aí . Eu tenho 5 inclusões aqui. Hoje mesmo é o meu dia de fazer relatório para mandar para as psicóloogas.É muito trabalho.

151 Entrevistador: Você participou da escolha do livro didático nesse ano?

152 Professor D: Não.

153 Entrevistador: Você chegou a receber o livro de ciências?

154 Professor D: Não. Só o de história e de geografia.

155Entrevistador: Só de história e geografia?

156 Professor D: Porque não tinha mais.

157 Entrevistador: Então quer dizer que o livro didático faz falta nessas disciplinas.

158 Professor D: Ah, faz falta. O de Português, todos tinham. Mas agora foram transferidos 2 e entraram 2 e esses ficaram sem o livro. Livro de professor nem pensar... e eu usei muito pouco esses livros aí. Não gostei não.

159 Entrevistador: O que você não gostou nesses livros? 
160 Professor D: Eu Não gostei o modo como ele foi abordado. Muito texto jogado, sabe? Não tem uma sequencia. Eu gosto de trabalhar os estilos de texto. Informativo, descritivo, dissertativo, ético. E você não encontra isso no material. Você só encontra o título ali. É uma historinha, depois um texto informativo. Não tem uma sequência. Gramática então nem pensar. Numa terceira já é para ter um domínio dos termos corretos da gramática.

161 Entrevistador: O que você achou daquele curso de ciências que eu dei?

162 Professor D: Eu achei bom. Você deveria dar mais daquilo. Você deveria dar de ciências e eu de alfabetização. Nós poderiamos até montar um curso aqui, entendeu?

163Entrevistador: O que você mudaria naquele curso?

164 Professor D: Naquele curso? O que eu mudaria? Deixaria as pessoas se inscreverem. Porque a pior coisa que tem é você estar do lado de uma pessoa que não está interessada.

165 Entrevistador: Mas eu deixei....

166 Professor D: Não foi imposto?

167 Entrevistador: Não.

168 Professor D: Porque eu gostei daquele curso e teve gente que gostou.

169 Entrevistador:E em relação ao tempo?

170 Professor D: Em relação ao tempo, poderia ser mais longo. Deveria ter uma hora e meia por dia. Aí você iria poder usar bem a parte teórica e a prática, né? Ninguém vai escutar isso né?

171 Entrevistador: Não. Só que que vou ouvir isso.

172 Professor D: Eu preparo toda a minha aula, sabe? Eu tenho dificuldade com a linha do tempo. Eu preparei uma atividade para eles de ciências assim: Imagine que você foi convidado a participar de uma campanha para a preservação do meio ambiente. Faça uma propaganda para essa campanha.É isso que eles estão fazendo. Fazendo uma propaganda para participar dessa campanha. A gente vai adaptando assim por força de vontade. Mas orientação a gente não tem nenhuma. Tudo que eu tenho eu que fui atrás. Inclusive hoje eu vou participar de uma palestra lá na Barão de Limeira sobre progressão continuada. Você quer ir?

173 Entrevistador: Eu não posso.

174 Professor D: São Professores da USP, da APEOESP e do CPP. Quem quiser ir lá é só se inscrever. A palestra é das 19 às $22 \mathrm{~h} 00$. E as coisas da folha são excelentes. Eu fiz um curso lá sobre como trabalhar com jornal, nossa eu fiquei apaixonada.

Professora E 


\section{Escola A}

33 Entrevistador: Nadja, você leciona há quanto tempo?

34 Professora E: No Estado, assim contando 19 anos.

35 Entrevistador: Você fez magistério primeiro?

36 Professora E: Fiz

37 Entrevistador: Além do magistério, você tem outro curso?

38 Professora E:Na Educação? Não. Só fiz o magistério.

39 Entrevistador: Durante o Magistério você se lembra de ter feito experiências em Ciências, de ter cursos relacionados às ciências?

40 Professora E: Sim. Tive Química, que eu gostava muito do jeito que o professor passava para a gente, né. Ele ensinava como a gente deveria trabalhar com as crianças. Ele até fez até um tipo de trabalho que até hoje me marcou. Você tinha que todo mês fazer um livrinho sobre uma matéria relacionada à quimica. Você tinha que fazer o livrinho e escolher o personagem. Era desenhado e não podia ser nenhum personagem conhecido, tá. E a experiência no laboratório.

41 Entrevistador: Ah, vocês tinham laboratório?

42 Professora E: Tinha. Uma coisa que eu gostei de fazer foi detergente biodegradável e não biodegradável. Aí era muito interessante porque nós tinhamos que fazer e apresentar para a sala. Cada um tinha uma vez, tá.

43 Entrevistador: Isso era o professor de Quimica que fazia. Você não teve didática do ensino de ciências? Metodologia do ensino de ciências?

44 Professora E: Não. Não.

45 Entrevistador: E você sente falta assim da prática?

46 Professora E: Sinto. Sinto.

47 Entrevistador: E como isto interfere no seu trabalho?

48 Professora E: Se tivesse alguém te dando amparo, você teria outras idéias, entendeu? E você acaba deixando de lado porque o que é mais importante? O Portugues e a Matemática. Eles até ficam querendo. Eu tenho alunos aqui com muita força de vontade. Alunos que lêem bastante. Tem alunos que até pesquisa as coisas por eles mesmos, entendeu? Mas eu sinto falta.

49 Entrevistador: Durante esses dezenove anos que está no Magistério. Você em algum momento teve algum curso de ciências? 
50 Professora E:Sim. Aqui no Marina Cintra. Você se lembra do curso que você deu? Que tinha muitas coisas interessantes de ciências que você relacionava uma matéria com a outra. Com Geografia, com história. Lembra da água? Era muito interessante.

51 Entrevistador: E fora esse curso, teve algum curso promovido pelo Estado, pela Oficina Pedagógica?

52 Professora E: Não. Nada. Nenhum. De ciências não.

53 Entrevistador: O que ficou para você desse curso que eu te dei?

54 Professora E: O que ficou para mim que é uma matéria tão importante quanto as outras. Mas por você não ser motivado, não ser preparado, você acaba deixando de lado.Mas o que eu achei interessante que com ciências você relaciona história,geografia, do mapinha que você ensinou. Você trabalhava os rios, os continentes, não sei se tou lembrada. Você chegou até trabalhar uma música do Guilherme Arantes. Planeta Água.

55 Entrevistador: Você chegou a desenvolver alguma atividade prática de ciências? E como foi o interesse de seus alunos?

56 Professora E: Foi...teve um bom resultado. Até aqueles mais assim, acabaram se interessando.

57 Entrevistador: E eles acabaram fazendo um relatório da experiência que fizeram.

58 Professora E: Sim, mas neste ano não.

59 Entrevistador: Então neste ano eles não tiveram atividade prática?

60 Professora E: Não. Não.

61 Entrevistador: Você participou da escolha do livro didático daqui da escola?

62 Professora E: Participei

63 Entrevistador: E o que você achou do livro didático de ciências?

64 Professora E: Não gostei. Modéstia a parte não utilizo. Eu utilizo outros livros, outros recursos, né? Eu acho que é muito extenso e não dá tempo de você dar.

65 Entrevistador: E como está o conteúdo deste livro?

66 Professora E: Eu acho muito complexo.

67 Entrevistador: Complexo como?

68 Professora E: Porque tem muita coisa que não dá para desenvolver com eles, tá? E as vezes precisa de uma pessoa para tá orientando a gente. E ciências você sabe...sempre acaba ficando naquelas coisinhas de livro. Não tem ninguém para te dar um respaldo, fica naquilo memso.

69 Entrevistador: O que você mudaria naquele curso que eu dei. 
70 Professora E: Eu acho que deveria até ter mais e para mais professores. Eu acho que você deveria de vir e dar aula para eles porque você tem mais experiência do que a gente.

71 Entrevistador: Se tivesse outro curso, como é que você gostaria que fosse esse outro curso?

72 Professora E: Da mesma forma entendeu? Da mesma forma. A unica coisa é que ser que ser assim: quem quer participar, participa. Para mim acrescentou muitas coisas.Eu acho que deveriam ter sim.

73 Entrevistador: Muitas pessoas estão falando sobre isso. Em algum momento este curso foi imposto para vocês? Porque eu cheguei e perguntei quem queria, né? Aí eu não sei se aquela outra pessoa na diretoria impôs isso para vocês. Eu não sei se a pessoa impôs.

74 Professora E: Não para quem fazia foi ótimo. Mas tinha gente que questionava. Tem HTPC e não tem o que fazer?Eu acho assim quem quer fazer, faz. Quem não quer não faz.

75 Entrevistador: Não porque aquele curso era ministrado no HTPC para quem quisesse fazer naquele horário. E quem quisesse ficar fora que saísse fora, né?

76 Professora E: Para mim foi ótimo né? Porque se eu fizesse fora do meu horário eu não conseguiria fazer.

77 Entrevistador: Por que você não consegue?

78 Professora E: Ah, porque eu tenho outras atividades. Outras ocupações.

79 Entrevistador: Qual o perfil da classe que você pegou nesse ano?

80 Professora E: Olha são bons no rendimento, têm vontade de aprender coisas novas.Alguns mesmos pesquisam por si próprios. E sempre tem aqueles que não está interessando em nada. Mas de uma forma geral todos eles são participativos, tá? Tem sempre aqueles que gostam mais de português, de ciências, de história. Eu acho uma sala boa.

81 Entrevistador: Então é isso, muito obrigada, viu?

Tempo: $10^{\prime} 41^{\prime \prime}$

Professor A

Escola A

1. Entrevistador: : Tudo bem professor?

2. Professor A: Tudo bem. (risos) 
3. Entrevistador: : Como foi essa turma que você pegou nesse ano? Qual o perfil da sala?

4. Professor A: Olha é uma sala que é considerada ela é considerada recuperação de ciclo porque ela tem todos os alunos que reprovaram o ano estão aqui. Eu tenho alunos com muita dificuldade mas tenho alunos que avançaram bem.

5. Entrevistador: : Eles chegaram semi-alfabetizados na sua sala? Qual é o nível assim de..?

6. Professor A: Então a maioria deles são alfabetizados. Eu devo ter assim um ou dois alunos que não são alfabetizados. Os demais apresentam muitas dificuldades mas são alfabetizados.

7. Entrevistador: : Você sabe como foi a escolha do livro didático de ciências daqui da escola? Você participou? Você chegou a ver os livros?

8. Professor A: Então geralmente a escolha dos livros funciona assim né?É feita uma exposição na sala aí os professores são convidados no HTPc para olhar os livros e coletivamente escolherem aqueles que mais agradaram. E assim, basicamente se escolhe uma editora para todas as disciplinas.

9. Entrevistador: Esse livro de ciências que foi escolhido... o que você tem a dizer sobre ele?

10. Professor A: Olha acho o livro é até interessante mas ele é um tanto quanto difícil . Quer dizer o livro é interessante por ser muitas experiências por ser muita base em cima das experiências, né, mas infelizmente nem sempre a gente tá fazendo essas experiências. A gente acaba fazendo aquilo que é mais tradicional, né? Uma vez ou outra a gente acaba fazendo experiência.

11. Entrevistador: Você chegou a fazer alguma experiência do livro?

12. Professor A: Eu realizei a experiência da....ai meu Deus...

13. Entrevistador: Não precisa dizer o nome técnico não, só fale do jeito que é.

14. Professor A: Aquela que a vida pode surgir de um material não vivo, entendeu, aquela experiência da carne que a gente deixa uma fechada e a outra aberta, aí vem a mosca, bota o ovo e vai surgir a larva e vai formar as moscas, né? Essa aí e uma outra do ....pão, que foi a parte de.. foi da... transformação do alimento quando....quando mastiga, né? Da participação da saliva, na mudança do gosto, até ...até engolir o alimento.

15. Entrevistador: Certo .E qual foi a reação dos alunos frente a essas experiências? 
16. Professor $A$ : Olha o que deu para perceber que o interesse é bem maior quando você trabalha com experiência. Essa do pão foi um pouco mais rápida, mas essa da carne que levou um tempo então a gente descia,ia lá fazia anotações, discutia,eles observavam, pegavam e assim o interesse de ir todo dia lá para ver o que tava acontecendo. Uma participação bem maior assim, parece que para eles é muito mais interessante quando é trabalhado experiência.

17. Entrevistador: No que se refere à parte escrita, como que eles foram? Em relação a escrever relatório?

18. Professor A: Então, o interessante é que eles tiveram facilidade em escrever assim, todo o processo, né ? Fizeram o desenho, escreveram todo o processo de como se deu desde aqui, o começo na sala e todo o desenvolvimento da experiência.

19. Entrevistador: Você imaginava que eles pudessem fazer isso?

20. Professor A: Não. Quer dizer imaginava, mas não tão assim profundo como eles fizeram. O interesse deles, né?

21. Entrevistador: Você participou do curso de ciências que eu dei no ano passado?

22. Professor A: Participei.

23. Entrevistador: O que você pensa ou pensou daquele curso?

24. Professor A: Eu penso que para a gente que trabalha de primeira a quarta como PEB I, a gente tem assim, polivalente... a gente tem formação para trabalhar todas as disciplinas, mas não é tão profundo. Então é muito bom quando a gente tem oportunidade de ter um aperfeiçoamento com uma pessoa da área, né mais adequada. A gente amplia mais o leque para tá trabalhado com as crianças, né?É muito interessante.

25. Entrevistador: O que você mudaria naquele curso

26. Professor A: Eu acho que o tempo. A gente precisaria de mais tempo para poder fazer né as coisas. Às vezes era muito rápido, então acho que com mais tempo seria melhor para todo mundo assim, mais prática, né?

27. Entrevistador: Mudou a sua prática depois do curso?

28. Professor A: Então, o que muda por exemplo né?.... é a gente perceber que quando você trabalha a prática e não fica só a teoria é bem mais interessante para os alunos e a aula consegue fluir melhor.É como a gente fez o curso. A gente trabalhava com a prática e a teoria oralmente.

Entrevistador: Se nós tivéssemos outra oportunidade outra oportunidade, que 
sugestões você daria para o próximo curso?

29. Professor A: Então como eu já disse, mais tempo para que esse curso aconteça com os professores, né ? Para que a gente possa realmente estar realizando as atividades na sala de aula.

30. Entrevistador: Poderia ser no final de semana?

31. Professor A: Sem problemas. Poderia.

32. Entrevistador: Obrigada. 
Anexo 9

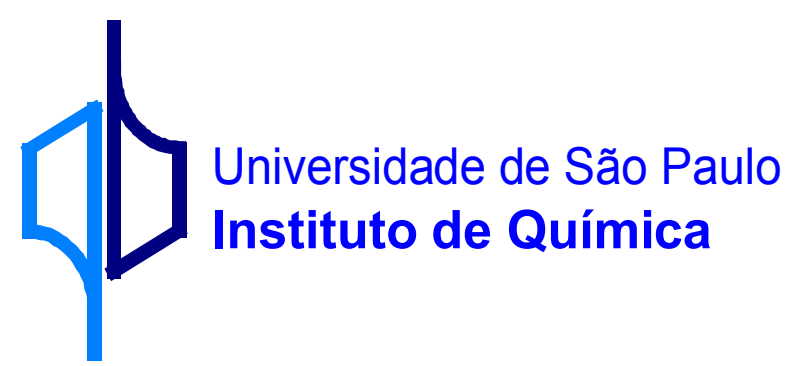

Faça um desenho sobre uma atividade ou experiência de ciências que a professora ensinou durante o ano e que você tenha gostado. Em seguida faça um pequeno texto relatando o que você aprendeu com esta experiência ou atividade. 